\title{
A Handbook and Reader of Ottoman Arabic
}

\author{
Edited by Esther-Miriam Wagner
}

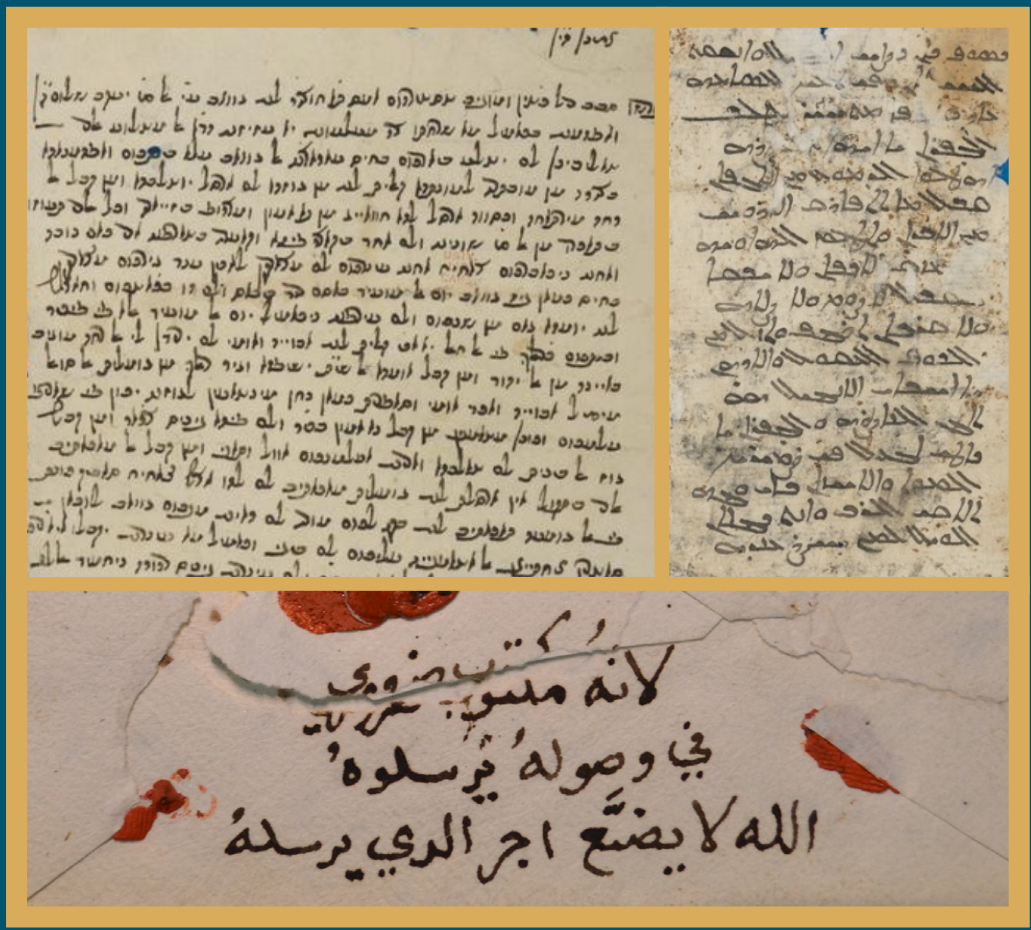


To access digital resources including:

blog posts

videos

online appendices

and to purchase copies of this book in:

hardback

paperback

ebook editions

Go to:

https://www.openbookpublishers.com/product/1168

Open Book Publishers is a non-profit independent initiative. We rely on sales and donations to continue publishing high-quality academic works.

\section{$\underset{\text { OpenBook }}{\text { Publishers }}$ \\ Knowledge is for sharing}




\section{A HANDBOOK AND READER OF OTTOMAN ARABIC}





\section{A Handbook and Reader of Ottoman Arabic}

Edited by Esther-Miriam Wagner 


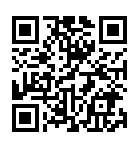

https://www.openbookpublishers.com

(C) 2021 Esther-Miriam Wagner. Copyright of individual chapters is maintained by the chapters' authors.

This work is licensed under a Creative Commons Attribution 4.0 International license (CC BY 4.0). This license allows you to share, copy, distribute and transmit the text; to adapt the text and to make commercial use of the text providing attribution is made to the authors (but not in any way that suggests that they endorse you or your use of the work). Attribution should include the following information:

Esther-Miriam Wagner (ed.), A Handbook and Reader of Ottoman Arabic. Cambridge Semitic Languages and Cultures 9. Cambridge, UK: Open Book Publishers, 2021, https:// doi.org/10.11647/OBP.0208

Copyright and permissions for the reuse of many of the images included in this publication differ from the above. Copyright and permissions information for images is provided separately in the List of Illustrations.

In order to access detailed and updated information on the license, please visit, https:// doi.org/10.11647/OBP.0208\#copyright

Further details about CC BY licenses are available at, https://creativecommons.org/ licenses/by/4.0/

All external links were active at the time of publication unless otherwise stated and have been archived via the Internet Archive Wayback Machine at https://archive.org/web

Updated digital material and resources associated with this volume are available at https://doi.org/10.11647/ОBP.0208\#resources

Every effort has been made to identify and contact copyright holders and any omission or error will be corrected if notification is made to the publisher.

Semitic Languages and Cultures 9.

ISSN (print): 2632-6906

ISSN (digital): 2632-6914
ISBN Paperback: 9781783749416

ISBN Hardback: 9781783749423

ISBN Digital (PDF): 9781783749430

DOI: $10.11647 /$ OBP.0208

Cover images: Upper left, T-S 10J16.26 (Hebrew script); upper right, CUL Or.1081.2.75.2 (Syriac script), both reproduced with kind permission of the Syndics of Cambridge University Library. Image below, from box HCA 32/212 from the The National Archives.

Cover design: Anna Gatti 


\section{CONTENTS}

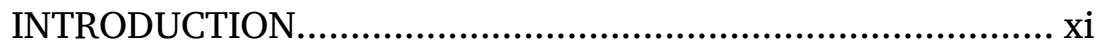

\section{HANDBOOK}

Michiel Leezenberg

1. Vernacularisation in the Ottoman Empire: Is

Arabic the Exception that Proves the Rule?.................... 1 Necmettin Klzllkaya

2. From Means to Goal: Auxiliary Disciplines in the

Ottoman Madrasa Curriculum 23

Guy Burak

3. On the Order of the Sciences for He Who Wants

to Learn Them

Guy Burak

4. Rumi Authors, the Arabic Historiographical

Tradition, and the Ottoman Dawla/Devlet 43

Christopher D. Bahl

5. Arabic Grammar Books in Ottoman Istanbul: The

South Asian Connection

E. Khayyat

6. Bastards and Arabs

II. READER

Dotan Arad and Esther-Miriam Wagner

1. Bodl. Ms. Heb. C. 72/18: A Letter by Isaac Bayt

'Atṭān to Moses B. Judah (1480s). 
Benjamin Hary

2. The Purim Scroll of the Cairene Jewish

Community 149

Dotan Arad

3. Appointment Deed of a Cantor in the Karaite

Community, Cairo (1575)

Nahem Ilan

4. Aharon Garish, Metsah Aharon....

Humphrey Taman Davies

5. Kitāb Hazz al-Quhūf (1600s)

Boris Liebrenz and Kristina Richardson

6. A Weaver's Notebook from Aleppo (10th/16th

century)

Michael Erdman

7. Selections from Arabic Garshūnī Manuscripts in

the British Library....

Liesbeth Zack

8. Excerpt from Yūsuf al-Maġribī’s Daf' al-iṣr 'an

kalām ahl Miṣr (1606) 209

Jérôme Lentin

9. Lebanon: Chronicle of al-Safadī (early 17th century [?])

Werner Diem

10. A Jew's Testimony Regarding a Statement Made in His Presence by a Muslim, Testified on Monday 20th Kislev 5418 (1657) 
Werner Diem

11. A Jew's Testimony Regarding a Statement Made in His Presence by a Muslim (1681)

Omer Shafran

12. A Basra Passover Haggadah with Judaeo-Arabic

Translation (ca. 1700)

Ghayde Ghraowi

13. Qahwa 'Coffee' (16th-17th centuries)

Jérôme Lentin

14. Egypt: Damurdāšī's Chronicle of Egypt (first half

of 18 th century)

Ani Avetisyan

15. Matenadaran Collection MS No.1751: A Medical

Work (1726) 255

Esther-Miriam Wagner and Mohamed Ahmed

16. A Clerical Letter by Rafael al-Ṭūki from the Prize

Papers Collections (1758) 261

Esther-Miriam Wagner and Mohamed Ahmed

17. A Christian Mercantile Letter from the Prize

Papers Collections (1759)........................................ 267

Feras Krimsti

18. Ḥannā al-Ṭabīb, Rịhlat al-Shammās Hannā

al-Ṭabìb ilā baldat Istanbūl (1764/65) 275 Jérôme Lentin

19. Syria 1: Chronicle of Ibn al-Ṣiddīq (1768) 283 
Ahmed Ech-Charfi

20. A Letter Transmitted by Ambassador Hajj Mahdī

Bargash from Sultan Muhammad Bin 'Abdallah to

Sultan Abdul Ḥamīd (1789 CE).................................289

Boris Liebrenz

21. Arab Merchant Letters from the Gotha Collection

of Arabic Manuscripts ..............................................293

Matthew Dudley

22. A Judaeo-Arabic Letter from the Prize Papers

Collection, HCA 32/1208/126.2 (1796) .......................307

Olav Ørum

23. The Cairo-Ramla Manuscripts, or the Ramle

KAR, 13 (1800s)

Magdalen M. Connolly

24. A 19th-Century Judaeo-Arabic Folk Narrative

Jérôme Lentin

25. Libya 1: Hasan al-Faqīh Hasan's Chronicle

Al-Yawmiyyāt al-Lỉbiyya (early 19th century)

Jérôme Lentin

26. Libya 2: Letter from Ġ̄̄ma al-Maḥmūdī (1795-

1858) to 'Azmì Bēk, Daftardār of the 'Iyāla

(Province) of Tripoli (undated).

Geoffrey Khan and Esther-Miriam Wagner

27. T-S NS 99.38 (1809)

Esther-Miriam Wagner and Mohamed Ahmed

28. Rylands Genizah Collection A 803 (1825) 365 
Jérôme Lentin

29. Syria 2: Chronicle of Muhammad Sa'īd

al-'Usțuwānī (1840-1861).....

Jérôme Lentin

30. Arabia: A Letter from Abdallah Ḥiṣānī to

'Abdallah Bāšā (1855)

Liesbeth Zack

31. Excerpts from Ya'qūb Șanū's Abū Naḍ̣̂āra Zar'a

and 'Abd Allāh al-Nadīm's al-Ustād

George Kiraz

32. A Disgruntled Bishop: A Garshūnī Letter from

Bishop Dinhā of Midyat to Patriarch Peter III.

Alex Bellem and G. Rex Smith

33. Aḥmad b. Muḥammad al-Jarādī: Sïrat al-Knawāja

al-'Akram al-Marhūum Harmān al-'Almānī

Esther-Miriam Wagner

34. Ora ve-Simḥa (1917)

Charles Häberl

35. A 'Mandæo-Arabic' Letter from Lady Drower's

Correspondence

Tania María García-Arévalo

36. An Anecdote about Juhā (1920s) ......................... 441 REFERENCES 



\section{INTRODUCTION}

The idea for this Handbook and Reader of Ottoman Arabic grew from a small seed. Originally, I had planned on an informal gathering with Geoffrey Khan, Rex Smith, and some fellow postdocs and students to talk about our respective Ottoman Arabic projects. To my great astonishment, a number of eminent Arabic linguists agreed to join us when I presented the idea, and from there we started drawing in Ottoman historians working on literacy and experts working on other languages in the Ottoman Empire. Our intended small workshop thus grew into the first conference on the topic, which took place in the Faculty of Asian and Middle Eastern Studies in Cambridge in 2016.

I had begun pondering the need for a volume focused on Ottoman Arabic after working on Early Modern sources in the Cairo Genizah, where the lack of reference works available to consult when working on these materials made for tedious checking of fringe dictionaries and dialectal grammar books. In my own experiences of being an Arabic student in Germany in the 1990s, in a very traditional German philology department, the Arabic texts taught had a chronological cut-off in the late medieval period. Students were provided with introductions to pre-Islamic poetry, Classical literature, and excursions into Muslim Iberian authors, but a contemptuous attitude prevailed towards anything written from the 15th century onwards.

Khaled Rouayheb $(2015,1)$ has summarised this attitude towards Ottoman Arabic in his description of the Ottoman period in the context of Arabic history as the perception of a "bleak 
chapter of cultural, intellectual, and societal 'decadence' (inhițāt) that began with the sacking of Baghdad by the Mongols in 1258 and came to an end only with the 'Arab awakening' of the nineteenth and twentieth centuries." When it comes to Arabic sources, this frame of mind is still quite wide-spread: more purely minded Arabic philologists might still recoil at the mention of philological work on these late Arabic sources characterised by vernacular influence and Middle Arabic orthography. This is why the gathering of like-minded people brought about much joy and an enthusiastic network of people who appreciate and work on Ottoman Arabic, who investigate literacies of Arabic in the Ottoman Empire, and who want to discuss the political, historical, and sociolinguistic circumstances behind Ottoman Arabic phenomena.

\subsection{Koineisation of Arabic in Ottoman Arabic}

Under Ottoman rule, we see a shift in Arabic literacy, and marked changes in the use of Arabic can be observed in various registers in contrast to earlier time periods. To a degree, this transformation follows on from changes in the Ayyubid and Mamluk period, but occurs on a much larger scale and extends to a much larger number of vernacular features.

The frequency with which these features occur depends on the literary genre of the texts concerned. Poetic, medical, and theological texts may show very few deviations from the norms of early medieval texts, whereas utilitarian prose in particular is marked by large scale introduction of vernacular and koine forms. 
Some of the more frequent changes are tied in with the religious affiliations of the writers. ${ }^{1}$ Although particular changes can be found in the case of Muslim writers, too, Christian and Jewish communities appear to have been less guided than their Muslim counterparts by the literary ideal of al-'arabiyya. As a result, where appropriate, the writings of Jews and Christians include a larger number of colloquial forms than those composed by their Muslim compatriots. Especially when writers attempted to connect to one another on an emotional level, we see colloquial forms occur in correspondence, or vernacular forms may be used to render speech in court documents.

Although Christian and Jewish texts may show a greater number of non-Classical forms than Muslim texts, due to religiously-anchored attitudes towards Classical Arabic among writers of the latter, this does not mean there are no shared trends observable in all Ottoman Arabic texts. A methodological flaw haunting grammatical description of Judaeo-Arabic and Christian Arabic texts is the method by which materials are compared to one another. Rather than comparing those forms which diverge from the Classical inventory to comparable contemporary texts, i.e., other letters, documents, philosophical texts, etc., analyses often concentrated on divergences from Classical Arabic only, thus incorrectly marking shared confessional forms as particularly Jewish or Christian.

The reality of Jewish or Christian Arabic forms was thus compared to the ideal of Muslim Arabic. Yet, Muslim texts are

\footnotetext{
${ }^{1}$ For a discussion on confessional varieties and their validity as a category, see Holes (2019), den Heijer (2012), and Wagner (2018).
} 
often slightly more prescriptive, and many progressive language features do indeed appear to emerge first in Jewish and Christian texts.

Language deviation is additionally facilitated by the use of a different alphabet-such as Hebrew, in the case of Judaeo-Arabic, or Syriac, in the case of Garshuni texts. The use of a different script appears to open avenues of orthography influenced by spelling conventions in the relevant contact language that are closed to writers only employing Arabic script.

\subsection{Shared Trends and Divergences of Koineisation across Confessional Boundaries}

Trying to answer the question of how the choice of alphabet influences the writing of Ottoman Arabic, the texts in this Reader reveal a heterogeneous picture. Obvious differences become apparent in terms of orthography. Double spelling of consonants in cases of gemination occurs increasingly in Judaeo-Arabic sources from the later medieval period, but is largely confined to $w$ and $y$. In the 19th and 20th centuries this appears to spread to all consonants, as in texts II.34 and II.36. Judaeo-Arabic texts of the later Ottoman period, in particular utilitarian prose texts, also reveal certain patterns of the realisation of short vowels that are hidden in Arabic script. The same can be found in texts written in Mandaic script, which, in addition to a large number of plenespelled vowels, also reveals the dialectal pronunciation of suffixes, such as Classical Arabic $-k$ as vernacular $-\check{c}$. Yet, other texts, in particular those written in Garshūnī, show an astonishing affinity to Classical Arabic orthographical norms. 
A divergent feature can be found in the spelling of otiose 'alif. In Judaeo-Arabic, this appears in medieval works, such as the Bible translation by Saadya Gaon, but has been lost in documentary sources. Christian utilitarian prose composed in Arabic, however, keeps this norm inherited from Arabic scribal traditions. Another divergent phenomenon is the vocalism patterns frequently found in Ottoman Judaeo-Arabic sources. Whether these patterns are specific to spoken Jewish Arabic or whether the use of the Hebrew alphabet allows shared colloquial speech patterns which were later abandoned by the other communities to emerge still needs to be investigated further.

The definite article preceding the 'sun letters' is most often not spelled in Judaeo-Arabic sources, but may also, albeit rarely, be missing in Christian and Muslim texts.

The very frequent plene-spelled short vowels, defective spelling of Classical Arabic long vowels, $\mathrm{n}$ for Classical Arabic short /a/, and tafkim and tarqi q in Judaeo-Arabic correspondence and in Mandaic sources is aided by the use of different alphabets and Hebrew and Mandaic orthographical conventions. Ta $\bar{a}^{\jmath}$ marbūta for $t \bar{a}^{\prime}$, however, occurs only in Christian letters, where it appears to be associated with the use of Arabic script.

The replacement of interdental fricatives by stops and the omission of final nūn of the nunation is shared in texts written by all confessions.

When we focus on the morphological, syntactic, and lexical levels, the differences become somewhat less pronounced. For example, while the vernacular bi-imperfect and the written koine 
form of lam as a general negation seem to emerge somewhat earlier in non-Muslim sources, they are common features found in texts written by members of all confessions. Pronouns and pronominal suffixes appear to be spelled colloquially mostly in nonArabic alphabets, but the phenomenon occurs in Arabic script as well.

The lexicon of non-Muslim writers often includes vocabulary from the liturgical languages of those communities, but these should be classed as register-specific loanwords. Utilitarian texts in all confessional groups, in particular, display a rich assortment of colloquial phenomena.

Overall, most Ottoman Arabic texts show increased influence of vernacular forms compared with medieval texts, and allow greater access to the spoken language. At the same time, written koine forms become customary in the texts.

In terms of shared and divergent features, the biggest faultline seems to be utilitarian prose versus literary texts, rather than along confessional boundaries, although non-Arabic scripts additionally facilitate the emergence of non-Classical forms.

\subsection{Notes}

Having met Efe Khayyat from Rutgers University at another conference and discovered our shared passion for Ottoman Arabic, the two of us set about organising another conference at Rutgers in 2017. With his support, more contributors to the volume were recruited. The meetings culminated in a third and final workshop at the Woolf Institute in Cambridge in 2019. 
When we discussed what form the written output of the conference could take, the idea of a Handbook and Reader of Ottoman Arabic emerged. The aim of such a volume would be to make a large number of short 15th-20th-century Arabic texts available and easily accessible to students and scholars of Arabic. Commentaries would elucidate shared linguistic phenomena and language change reflected in the written sources.

The Handbook section thus gathers articles intended to educate about a wide range of topics pertaining to literacy and education in the Ottoman Empire. The Reader section contains samples of texts provided by over twenty-five different scholars. Some of the texts were reproduced from other publications, with the obligation to leave them unchanged in this edition. Classical Arabic transcriptions and conventions were used alongside colloquial modern counterparts. It was therefore not possible to employ a homogenous transliteration system. This was somewhat difficult for me, conditioned by my Germanic schooling, but I have embraced the spirit of variationism.

The articles in the Handbook section have the references added at the end of each article, while the references for the Reader section are gathered at the end of the volume.

All texts in the Reader part that were originally composed in scripts other than Arabic have been rendered in Arabic transcription in order to allow access for scholars unfamiliar with the Hebrew, Syriac, and Mandaic alphabets. The transcription follows the system developed by Werner Diem (2014), and serves to open up the original text to the uninitiated, especially to native readers of Arabic. In the transcriptions, no statements are made 
xviii Handbook and Reader of Ottoman Arabic

about place of articulation or vowel quality or quantity, and no attempt has been made to provide a normalised Arabic version of the original text.

The table below shows the transliterations for the Classical texts:

\begin{tabular}{|c|c|c|c|}
\hline 1 & , & ض & $d$ \\
\hline ب & $\mathrm{b}$ & b & $\mathrm{t}$ \\
\hline ت & $\mathrm{t}$ & ظ & $\mathrm{z}, \underline{\mathrm{d}}$ \\
\hline ث & $\underline{\mathrm{t}}, \mathrm{th}$ & $\varepsilon$ & ' \\
\hline ج & $\mathrm{j}$ & $\dot{\varepsilon}$ & $\dot{\mathrm{g}}, \mathrm{gh}$ \\
\hline$\tau$ & ḥ & ف & $\mathrm{F}$ \\
\hline$\dot{\tau}$ & $\mathrm{h}, \underline{\mathrm{k}}, \mathrm{kh}$ & ق & Q \\
\hline 2 & d & 5) & K \\
\hline$\dot{~}$ & $\underline{\mathrm{d}}, \mathrm{dh}$ & $J$ & $\mathrm{~L}$ \\
\hline$\jmath$ & $\mathrm{r}$ & r & M \\
\hline j & $\mathrm{z}$ & ن & $\mathrm{N}$ \\
\hline س & s & 0 & $\mathrm{H}$ \\
\hline ش & $\check{\mathrm{s}}$, sh & 9 & W \\
\hline ص & $\underline{\mathrm{S}}$ & $ى$ & $\mathrm{Y}$ \\
\hline
\end{tabular}




\subsection{Acknowledgments}

This volume would not have been possible without the support of many institutions and individuals. First and foremost, my heartfelt thanks go to all the scholars who have contributed to this volume: Dotan Arad, Ani Avetisyan, Christopher Bahl, Alex Bellem, Guy Burak, Magdalen Connolly, Humphrey Davies, Werner Diem, Ahmed Ech-Charfi, Matthew Dudley, Michal Erdman, Tania García-Arévalo, Ghayde Ghraowi, Charles Häberl, Benjamin Hary, Nahem Ilam, Geoffrey Khan, George Kiraz, Feras Krimsti, Efe Khayyat, Necmettin Kizilkaya, Michiel Leezenberg, Jérôme Lentin, Boris Liebrenz, Olav Orum, G. Rex Smith, Kristina Richardson, Omer Shafran, Liesbeth Zack.

The Woolf Institute supported me first through a Research Fellowship, then appointed me as Director of Research and finally as Executive Director, always allowing me to continue my research passions, with funding provided for all three workshops.

The Faculty of Asian and Middle Eastern Studies of the University of Cambridge provided funding towards the first and third workshops. Rutgers University and Efe Khayyat funded the second workshop, while the T-S Genizah Research Unit of the Cambridge University Library contributed to the first workshop.

My profound gratitude goes to Gottfried Hagen, whose advice was crucial for the organisation and conduct of all three workshops. Geoffrey Khan and Clive Holes were ever supportive, and we had great intellectual input from Enam al-Wer, Helen Pfeifer, and Hakan Karateke. Thanks also go to John-Paul Ghobrial, Didem Havioglu, Tuna Artun, Peter Hill, and Khaled el- 
Rouayheb, a well as all Woolf Institute staff who facilitated the conferences.

Last but not least, I owe a great debt to Aaron Hornkohl, Alissa Symon and Flora Moffie, who with great enthusiasm and passion helped me in bringing this volume together. 


\section{HANDBOOK}





\section{VERNACULARISATION IN THE OTTOMAN EMPIRE: IS ARABIC THE EXCEPTION THAT PROVES THE RULE?}

Michiel Leezenberg

\subsection{Introduction to the Ottoman Cosmopolitan}

Arabic, Charles Ferguson has famously told us, is-like modern Greek-a diglossic language, 'high' and 'low' varieties of which are used in different and complementary settings. Diglossia differs from bilingualism in that it involves two varieties of the same language; moreover, the high variety lacks native speakers, and is acquired only in formal educational settings, and used only in official and/or written forms of communication. This diglossia, he adds, has proved remarkably resilient and enduring. Since their original publication in 1959, however, Ferguson's ideas have been modified and refined: varieties of modern Arabic other than the two reified high and low registers have rightly been distinguished; and the diglossic situation in Arabic, and even more in modern Greek, has been shown to be rather less stable and 
more contested than Ferguson's irenic picture would have us believe. ${ }^{1}$

Here, I would like to suggest that we can fruitfully explore the topic of Arabic diglossia-and of the development of modern Arabic more generally-laterally, and in a comparative and diachronic manner. More concretely, when studied in their broader Ottoman and post-Ottoman settings, the diglossic constellations of Arabic and Greek turn out to be but two very distinct outcomes of a rather broader process of vernacularisation, that is, a shift from written classical to locally spoken language varieties, in which hitherto spoken languages started being used for new literate uses, such as, most importantly, official courtly communication, high literature, and learning. This broader process in fact occurred across virtually the entire the Ottoman Empire; its consequences are still visible in the Empire's various successor states. Here, however, I will not discuss the case of Arabic in detail; rather, I will briefly sketch the wider pattern of development, and leave discussion of the implications for the study of Arabic to another occasion.

I take my cue from Sheldon Pollock, who has, famously, identified a number of cosmopolitan orders in the world of Latinity and the Sanskrit-based civilization in and around the Indian subcontinent during the first millennium CE; both of these orders, he

\footnotetext{
${ }^{1}$ Ferguson has also identified a number of what he calls 'myths' about Arabic (or what we would nowadays call 'language ideologies' or 'folktheoretical beliefs') among its native speakers; among the most important of these, he argues, is the widespread, and ardently defended, belief that, despite all the dialectal and other varieties one encounters, there is but one single Arabic language.
} 
further argues, went through broadly similar processes of vernacularisation around the year $1000 \mathrm{CE}^{2}$ In Western and Southern Europe, this process yielded written Romance languages like Italian, Catalan, and French; in South Asia, vernaculars like Tamil, Telugu, and Kannada were similarly promoted to written status. Thus, vernacularisation is not specifically or uniquely modern or European; it may occur at different times and in different places.

The Ottoman Empire, as I hope to show below, knew a cosmopolitan order similar to those of Sanskrit and Latinity; and it, too, went through a massive wave of vernacularisations, in the 17 th and 18th centuries CE. These vernacularisations, moreover, paved the way for the new, vernacular language-based ethnic identities and national movements that emerged in the course of the 19th century. In their earlier stages at least, these identities and movements developed largely, if not completely, independently of any cultural, ideological, or political influence or interference from Western or Central Europe. Thus, the widely held but rarely investigated assumption that national identities outside Europe were crucially influenced by European (and, more specifically, German) romantic nationalism and shaped by the categories of philological orientalism would seem to deserve reconsideration.

Although many discussions of nationalism contrast the multilingualism of premodern empires with the monolingual ideals and the linguistic standardisation of modern nation states, few empires can match the diversity and complexity of the early mod-

\footnotetext{
${ }^{2}$ For a brief statement, see Pollock (2000).
} 
ern Ottoman linguistic constellation. In the Ottoman Empire, Arabic enjoyed a high status as the language of the revelation of Islam and of Islamic religious learning; but it was not the only written language of prestige even among Muslims, let alone other population groups. Famously, the Ottoman elites recognised 'the three languages' (elsine-i selâse) that dominated literate communication: Arabic for religious learning, Persian for poetry, and Ottoman Turkish for administration and official correspondence. The latter, as is well known, was a form of Turkish with a large, if highly variable, proportion of vocabulary items and grammatical constructions borrowed from Arabic and Persian; being virtually incomprehensible to the uneducated masses, and deliberately so, it also served as a marker of social distinction for the Ottoman bureaucratic elites. ${ }^{3}$

Christians living in the Empire had a number of classical, or sacred, languages of their own: in theory, Koinè Greek served as the language of liturgy and learning for all Orthodox Christians in the Empire, although some Orthodox communities used other ancient tongues, like Old Church Slavonic in the Balkans or Arabic in the Levant. Armenians, who had had their own church for centuries, used Grabar, or classical Armenian, as a liturgical and learned language; and Eastern Christians of different denominations generally used Syriac, which had been the regional lingua franca in the Fertile Crescent prior to the arrival of Arabic, but by the early modern period had become a dead language, and was used exclusively in formal and/or written communication.

\footnotetext{
${ }^{3}$ Cf. Mardin (1961).
} 
The spoken varieties of these languages had a rather lower status-so low, in fact, that, among Greeks and Armenians in particular, one observes substantial language loss and a shift towards locally dominant languages or spoken linguae francae like Turkish, colloquial Arabic, or Kurdish. There is no evidence that this language shift was due to repressive Ottoman policies, as some nationalist historians have claimed; in fact, there is little evidence of any substantial Ottoman language policies prior to the last decades of the 19th century CE.

Among Ottoman Jews, the 'Sacred Language' (leshon haqodesh), a blend of Hebrew and Syriac, was the main written language prior to the arrival of large numbers of Sephardic Jews from the Iberian Peninsula in the late 15th and early 16th centuries. The main written language of this group was 'Judaeo-Hispanic,' grammatically a calque of the sacred language with a large number of Hispanic lexical items; this was distinct from 'Ladino' in the strict sense, the commonly spoken variety of JudaeoHispanic, which was much closer to colloquial 15th-century Spanish. ${ }^{4}$

Apart from these, there were also languages that had little or no written tradition like, most significantly, the Romance varieties spoken by several Orthodox Balkan Christian groups, Al-

\footnotetext{
${ }^{4}$ Remarkably, Evliya Çelebi describes what he calls lisân-ı Yahûdî, or 'the Jewish language,' as spoken in Safed in Ottoman Palestine (Dankoff et al. 2011, 3/74); but this language turns out to be neither classical Hebrew nor Aramaic, nor any offshoot from the Sacred Language, but a spoken dialect of Judaeo-Hispanic.
} 
banian, and Kurdish, not to mention a number of mixed languages like the famous 'Asia Minor Greek,' which was almost exactly half Greek and half Turkish in its vocabulary and grammar, and the language varieties spoken by the Dom, or 'Gypsy', groups in different parts of the Empire. Although we have rather less information about these spoken vernaculars on the verge of the vernacularisation wave, we are fortunate in having a rich and relatively reliable source of information in Evliya Çelebi's famous Seyâhatnâme, or 'Book of Travels', which was written in the mid17th century CE but not published until three centuries later. ${ }^{5}$ Spoken language is always foremost in Evliya's mind, with sex a close second. Accordingly, the Seyâhatnâme offers a plethora, not only of basic vocabulary and stock phrases in various Ottoman vernaculars, but also obscene expressions. The care and precision of its transcriptions make this work a precious source for linguists even today.

\subsection{Early Modern Ottoman Vernacularisation}

Evliya observes that in the medreses of the Empire's outlying regions, Arabic and Persian were the main languages of instruction; but he also describes how Muslims in Ottoman Bosnia used a small Turkish-Bosnian lexicon-a vocabulary that has become known, and in fact appears to have gained a rather wide circulation, under the title of Potur shahidiyya (Dankoff et al. 2011, 5/229-30). That is, he points to the vernacularisation of 'Bosnian', i.e., the locally spoken South Slavic dialect, which was very

\footnotetext{
${ }^{5}$ The best modern edition of the Seyâhatnâme is Dankoff et al. 2011); for a generous selection in English, see Dankoff and Kim (2010).
} 
close to the varieties that have subsequently become known as Serbian and Croat. This is one of the earliest examples of a much broader pattern of vernacularisation in the early modern Ottoman Empire: between the 17th and the early 19th centuries CE, various Ottoman population groups in different parts of the Empire shifted to new written uses of local vernacular languages. ${ }^{6}$ The best known, and best documented, examples of this process are probably those among the Empire's various Christian groups. First and foremost, among Ottoman Greeks, a movement arose in the mid-18th century, pioneered by authors and actors like Iosipos Moisiodax and Adamantios Korais, which propagated the use of language varieties closer to locally spoken dialects than the millennia-old Koinè Greek, with the aim of making Greeklanguage education easier and less time-consuming. Amidst fierce polemics, Korais-ultimately successfully-argued that a modern, civilised Greek nation should speak and write neither a vulgar dialect nor the old-fashioned Koinè Greek, but a purified form of language (subsequently called Katharevousa), which was free of Turkish loans and enriched with neologisms to express modern concepts. Likewise, among Ottoman Armenians, in early modern times a new, supraregional variety emerged, called K'aghak'akan or 'the civil language', which was much closer tothough not identical with—regionally spoken dialects, and hence

\footnotetext{
${ }^{6}$ For a more detailed overview, see Leezenberg (2016). A book-length account, provisionally entitled From Coffee House to Nation State: The Rise of National Languages in the Ottoman Empire, is currently in preparation.
} 
much easier to learn, read, and write than classical Armenian. ${ }^{7}$ In the Ottoman Balkans, authors like Dositej Obradovic and Vuk Karadzic encouraged the written use of South Slavic (subsequently labelled 'Serbian'), against the dominance of both Koinè Greek and Old Church Slavonic; among Ottoman Serbs that had sought refuge in the Austro-Hungarian Empire in the 1690 exodus headed by patriarch Arsenije III, a supraregional language for learned and literate communication emerged that was called 'Slaveno-Serbian;' its use was actively encouraged by the Habsburg authorities, as a way of countering Russian linguistic, religious, and political influences. Further Eastward, in the Danube provinces, mid-18th-century authors like Paisii Hilendarski and Sofronij Vracanski simultaneously preached and practiced the literate use of the Bulgarian, or as they called it, 'Slaveno-Bulgarian', vernacular; and already earlier in the century, the famous Dimitrie Cantemir had pioneered the written and printed use of Romance vernacular locally called 'Wallachian', but subsequently labelled 'Romanian.' Initially, Cantemir appears to have intended this Romance vernacularisation as a way of countering the influence of Old Church Slavonic; but its later proponents emphasised the venerable pedigree of this vernacular in the Latin of antiquity, in an obvious effort to counter the dominance and prestige of Koinè Greek.

But these developments were not restricted either to the Empire's European provinces or to its Christian population groups. The Sephardic Jewish communities witnessed (or rather,

\footnotetext{
${ }^{7}$ For Modern Greek, see, e.g., Horrocks (1997) chapters 13-17; Ridgway (2009); for Armenian, see Nichanian (1989).
} 
caused) the emancipation of spoken Ladino as a medium of religious learning in the early 18th century. During the same period, Muslim Albanians started to produce Arabic-Albanian and other vocabularies for educational purposes, and started composing learned divan poetry in an Albanian enriched with Arabic, Persian, and/or Ottoman Turkish expressions, locally called bejtexhi or 'Bayt poetry'. In the Empire's Easternmost provinces, Kurdish authors like Ehmedê Xanî started using Kurmanji or Northern Kurdish both for didactic works and learned mathnawî poetry. In Mesopotamia, different denominations of Eastern Christians started using different forms of modern Aramaic, as distinct from classical Syriac, for literate, literary, or liturgical purposes. Even Ottoman Turkish witnessed significant attempts at simplifying the written language of bureaucracy in the 18th century in the direction of the Turkish dialect spoken in Istanbul, to the dismay of some officials, who feared they could no longer show off their social and linguistic distinction. ${ }^{8}$ This period also witnessed significant linguistic shifts among different Ottoman population groups: in the 18th century, substantial numbers of so-called Romaniotes, or Greek-speaking Jews of the Ottoman Balkans, started speaking Ladino; and many Copts in Egypt and some Eastern Christians in the Mashriq and in Mesopotamia, appear to have become Arabised, largely abandoning their traditional vernaculars in favour of colloquial Arabic.

${ }^{8}$ Cf. Mardin (1961). 


\subsection{Attempts at Explanation: The Role of Vernacular Philologies}

The fact that similar processes of vernacularisation occurred across, and perhaps even beyond, the early modern Ottoman Empire calls for explanation. At present, however, we are at a loss for any such explanatory account. For linguists, it would seem reasonable to suspect some kind of areal convergence or other form of language contact; this would raise the further question of whether such common or converging innovations simultaneously occurred in several languages, or rather started in one language, which then triggered similar changes in others. Such areal explanations, however, may be only part of the story: given that vernacularisation involves written rather than spoken language forms, and literate elites rather than the uneducated masses, such questions of cultural contact may also involve factors that are not strictly or structurally linguistic. To mention but one example: although the spoken varieties of Southern Slavic known today as Serbian, Croat, and Bosnian were mutually intelligible, and were in contact in urban centres like Sarajevo, the written traditions developed by authors writing in each of these three vernaculars were, for all practical purposes, completely independent from one another, if only because they involved, respectively, the Cyrillic, Latin, and Arabic alphabet.

One obvious level to look for explanations is the Ottoman political economy, in particular the well-known phase of some form of economic 'liberalisation,' coupled with a relative political 
decentralisation, in the 17 th and 18 th centuries CE. ${ }^{9}$ Perhaps, then, we may fruitfully relate early modern cultural and linguistic phenomena to the rise of mercantilism; and indeed, among the Greek and Armenian communities in the major cities of the Western Ottoman Empire, like Istanbul, Izmir, and Salonica, something like a mercantile bourgeoisie had emerged, which had become affluent through trade with Christian powers, especially in the Western Mediterranean and Central Europe. The rise of such new secularised elites may tempt us to see linguistic developments among them as triggered and inspired by the cultural epiphenomena of such commercial contacts, and in particular by imported ideas associated with the Enlightenment and early Romantic nationalism. But quite apart from the question of whether there were any concrete and coherent vernacularising doctrines or tendencies specific to the European Enlightenment, such an explanation overstates Western European influence and downplays local Ottoman dynamics. These vernacularising processes, after all, took place not only among the European-oriented mercantile bourgeoisie in the Empire's urban centres, but also among different population groups in its more remote and isolated rural peripheries.

Given these difficulties, we should perhaps first try to isolate and explicate all potentially relevant linguistic, sociolinguistic, and other factors before attempting any explanation. There are several such factors that may help in guiding our explanations; but here, I will discuss only the role of printing and of vernacular philologies. First, it should be noted that some, but by no

\footnotetext{
${ }^{9}$ See, e.g., Inalcik and Quataert (1994, parts II and III).
} 
means all, of these vernacularising movements were accompanied and facilitated by the use of printing. Thus, texts in different varieties of Greek and Armenian were printed in centres like Venice and Vienna, primarily targeting publics living in Ottoman territory and often sponsored by wealthy Ottoman citizens. Even more intriguingly, these foreign presses also produced materials written in Turkish, but printed in Greek or Armenian characters (subsequently called, respectively, 'Karamanlidiki' and 'ArmenoTurkish literature'), indicating that by this time, a substantial part of the affluent reading publics could read these scripts, but had long since shifted to spoken Turkish. The Empire's Sephardic Jews had known-printing in Judaeo-Hispanic since the 16th century $\mathrm{CE}$; but from the early 18th century on, printed works of religious learning (and, later, increasing numbers of secular texts) in colloquial Ladino started being published as well. Famously, Ibrahim Müteferrika's government-sponsored press printed a number of works in Ottoman Turkish in the first half of the 18th century; but in the face of protests from scribes and copyists, and more importantly of disappointing sales, it discontinued activity. Other vernacularising movements, however, like those among Albanians, Bulgarians, and Kurds, would not involve printed texts until well into the 19th century. In short, the mere availability of printing technology was in itself neither a causal factor nor a necessary feature of the various Ottoman vernacularisations. ${ }^{10}$

\footnotetext{
${ }^{10}$ This is one serious problem for Benedict Anderson's influential (1991) argument that it was 'print capitalism', or the mere availability of the
} 
A second important if variable aspect of Ottoman vernacularisation is the appearance of vernacular grammars. The writing, let alone printing, of such grammars points to a later stage in the process of Ottoman vernacularisation, which stretches from the mid-18th to the mid-19th century. Until then, grammatical instruction was generally restricted to classical or sacred languages among Muslims, Christians, and Jews alike. In Muslim educational institutions, only Arabic grammar was studied systematically; Persian was acquired not by studying grammatical textbooks, but by reading works like Sa'dî’s Golestan; and Ottoman Turkish, which had no fixed grammatical or stylistic rules or norms to begin with, appears to have been acquired informally, or simply to have been presumed as known. Even less current was any belief that locally spoken dialects were worthy of having their grammars written down and studied-or indeed that they had a system of grammatical rules to begin with. Generally, vernaculars appear to have been seen as deviations from classical norms or rules, rather than as full-fledged languages having rules of correctness of their own. ${ }^{11}$

This was to change in the 18th century: during this period, one witnesses the development of what one may call 'vernacular philologies', in particular through the writing of grammars and

technology of printing within a capitalist mode of production, which made possible the rise of superstructural or ideological 'imagined community' of the nation.

${ }^{11}$ An intriguing exception may be Evliya Çelebi, who in his Seyâthatnâme, conceives of all (spoken and written) languages as analogous to religions, each of them revealed by a specific prophet and having a sacred scripture of its own (Seyâhatnâme II:256a; Dankoff et al. 2/57). 
lexica for various vernaculars. To mention but a few: in 1757 , Dimitri Eustatievici wrote a Romanian grammar, Gramatica $\mathrm{Ru}$ maneasca; but this text would not be printed until well into the 20th century. Likewise, probably around the mid-18th century CE, Elî Teremaxî composed a Tesrîfa Kurmancî or 'Kurdish morphology' in Kurmanjî or Northern Kurdish. Written for young Kurdish-speaking medrese pupils taking their first steps in Arabic grammar, this work gained a wide circulation in the rural medreses of Northern Kurdistan, and, in fact, continued to be used clandestinely even after the rulers in the new republic of Turkey ordered the closing down of all medreses in the 1920s. In 1815 Vuk Karadzic wrote a grammar of his native dialect of Serbian, the Pismenica serbskoga jezika, at the request of his friend Jernej Kopitar; this work was to gain rather wider circulation in Northern European historical-comparative linguistic circles thanks to Jakob Grimm's 1824 translation, the Kleine serbische Grammatik. In 1835, Neofit Rilski had a Bolgarska gramatika printed for use in schools trying to rid themselves of Greek linguistic and cultural dominance. And as late as 1851, Ahmed Cevdet Pasha published a Kavâ'id-i Osmaniyye 'Principles of Ottoman [Turkish]', which was to go through numerous printed editions in the following decades.

It should be emphasised that these new vernacular philologies owe less to modern Western philological orientalism than to local classical traditions. Even in a relatively late work like Cevdet and Fuad Pasha's textbook, the categories employed are those of traditional Arabic grammar, rather than of modern Western philology. Thus, in its treatment of the locative and ablative 
case, evidentials, and vowel harmony, the Kavâ'id-i Osmaniyye differs radically from A. L. Davids's 1832 Grammar of the Turkish Language, which some modern scholars, mistakenly, have seen as a source of inspiration for Cevdet's work. ${ }^{12}$ In short, a strong argument can be made that these vernacularising processes, and the emergence of new local vernacular philologies, preceded any influence or hegemony of modern Western orientalist philology.

The historical and theoretical significance of these vernacular grammars has not yet been assessed. Here, however, I wish to suggest that they not only mark an important dimension of the vernacularisation of various Ottoman languages; they also embody a step in what one may call the governmentalisation of language, that is, in a process that simultaneously turned vernacular languages into objects of knowledge and objects of governmental concern. One of the main aspects of modern nationalism, after all, is that all subjects are to be turned into full-blooded citizens, and into loyal members of the nation, by universal education in a standardised, unified and codified version of what is called 'the mother tongue'; and that the spread and implementation of this mother tongue through educational systems and institutions is one of the primary responsibilities of the new institution of the nation state. The history of modern nationalism, that is, is also a history of how vernacular languages-or new forms of language much closer to spoken dialects-simultaneously became instruments of mass communication, symbols of identification, and objects of government.

\footnotetext{
${ }^{12}$ For a more detailed argument, see Leezenberg (2021).
} 


\subsection{A Sonderweg for Arabic?}

At first blush, Arabic seems to form the most important, if not virtually the sole, significant exception to this empire-wide process of vernacularisation. Although dialectal or colloquial traces appear in various Arabic-languages of different ages, no authors openly proclaim or propagate either the written use of vernacular forms of Arabic, or the modernisation or purification of the Arabic language prior to the nahda, or literary Renaissance movement, that emerged in the mid-19th century. But perhaps we simply have not looked closely enough, or have been misled to some extent by the pervasive linguistic ideologies concerning the unity and uniqueness of Arabic.

Considerations of space, and lack of relevant expertise, prevent me from pursuing these questions in greater detail; but here, I would merely like to suggest that the study of Ottoman Arabic may be enriched by a more systematic contextualisation: we can, and perhaps should, ask whether and how the structure, use, and ideologies of Arabic were affected by developing institutions and practices of government, and compare and contrast the development of Arabic with that of other languages in the Ottoman Empire. To take but one example, one may think of so-called 'Middle Arabic' typologically as a specific style or register of Arabic between the normative ideal of Classical Arabic and the colloquial realities of local dialects, rather than historically, as a developmental stage or period as was done by earlier scholars. ${ }^{13}$ In doing so, however, we may come to see the similarities and divergences

\footnotetext{
${ }^{13}$ I owe this suggestion to Clive Holes (personal communication).
} 
between Arabic and other Ottoman languages in a rather different light. As discussed above, speakers of several other Ottoman languages also developed supraregional forms that consciously differed from, and acted as intermediaries between, on the one hand, the classical norm and, on the other hand, the regional, 'vulgar' dialects. The modern Greeks developed Katharevousa; among Ottoman Armenians, a supraregional 'civil language' (K'aghak'akan) emerged; and Serbian exiles produced an educated Slaveno-Serbian. Only Greek and Arabic, however, retained an enduring diglossia, whereas both Civil Armenian and SlavenoSerbian disappeared in the 19th century.

There was nothing inevitable about these outcomes. Prior to the 1815 publication of Karadzic's Pismenica serbskogo jezika, several grammars of Slaveno-Serbian had been written and printed; in fact, Karadzic's own grammar has been shown to be a calque of one of these grammars, which simply replaced SlavenoSerbian items and paradigms with dialectal ones. ${ }^{14}$ And Nichanian (1989) describes how a substantial literature (both translated and original) in Civil Armenian had circulated before being replaced by a variety closer to the dialects spoken in the Empire, called 'Western Armenian'. Thus, even if the process of vernacularisation occurred throughout the Ottoman Empire, its outcomes varied widely across different languages.

The brings up the substantial question why only Greek and Arabic retained a relatively stable diglossic constellation, whereas languages that emerged from broadly similar backgrounds, like Armenian and the Slavic languages, did not.

${ }^{14}$ This was argued in detail by Thomas (1970, 14-21). 
One crucial factor appears to have been the role of language ideologies: among Greeks and Arabs alike, the belief that, despite all dialectal differences and diachronic developments, their language-like their nation-was and should remain a unitary and unified entity appears to have predominated, and to have created the preconditions for relatively stable and enduring-if by no means uncontested-diglossia. Among Armenians, by contrast, the language-ideological belief that a modern language should be closer to the dialects of 'the people' appears to have carried the day. Finally, Slavic languages, and apparently also the various forms of Neo-Aramaic, appear to have been shaped by what has been called 'fractal logic' (cf. Gal 2005), which leads to ever-greater linguistic differentiation alongside the proliferation of new ethnic or sectarian antagonisms. In the mid-19th century, attempts at creating a unified 'Serbo-Croat' language seemed to be successful, but the two main varieties continued to be written in different scripts; and since the wars of the 1990s, efforts to emphasise the linguistic differences-not only between Serbian and Croat, but also with Bosnian and Montenegran-have been further stepped up. Another South Slavic vernacular, Bulgarian, appears to have followed a similar fractal logic: it came to be seen, and used, as a distinct Slavic language only in the later 18th century, and by the turn of the 20th, a movement had emerged that claimed 'Macedonian,' which hitherto had been classified as 'Western Bulgarian,' as a language in its own right; and the fractalising process may not have ended there. Similarly, in Northern Iraq, among Eastern Christians of different denominations, a bewildering variety of modern and 
not-so-modern standards of written Modern Aramaic has emerged, without any one variety gaining a wider currency. ${ }^{15}$

In short, common processes of vernacularisation have had very different results in different languages, depending in part on linguistic ideologies, on ethnic and sectarian relations, and on vernacular philologies. Most, if not all, of these outcomes, it should be noted, had already been more or less decided (though by no means completed) by the end of World War I, that is, prior to the formation of the Ottoman successor states and the imposition and permeation of national languages through educational institutions and mass media. Thus, they were not dependent on, or decided by, sovereign state power; hence, it may be useful to study Ottoman processes and patterns of vernacularisation neither in purely linguistic terms nor in terms of sovereign state power, but with an eye to the development of vernacular philological traditions as a crucial factor in linguistic governmentalisation.

\section{References}

Anderson, Benedict. 1991. Imagined Communities. 2nd edition. London: Verso Books.

\footnotetext{
${ }^{15}$ One might also argue that, in early modern times, speakers of Turkish knew an Ottoman-colloquial Turkish diglossia; but there was little if any sense that these were two levels or registers of the same language. The labels used for both may be significant: generally, Ottoman Turkish was called Osmanlıca or Osmanî, and colloquial Turkish Türkçe or Kaba Türkçe 'coarse Turkish'; Evliya refers to the former as Lisan-ı Rum, and to the latter as Lisan-ı etrâk.
} 
Burke, Peter. 2004. Languages and Communities in Early Modern Europe. Cambridge: Cambridge University Press.

Butler, Thomas. 1970. 'The Origins of the War for a Serbian Language and Orthography'. Harvard Slavic Review 5: 1-80.

Dankoff, Robert, et al. (eds). 2011. Evliya Çelebi seyahatnamesi. Istanbul: Yapı Kredi Yayınları.

Dankoff, Robert, and Sooyong Kim (trans.). 2010. An Ottoman Traveller: Selections from the Book of Travels of Evliya Çelebi. London: Eland.

Ferguson, Charles. 1959. 'Diglossia.' Word 15 (2): 325-40. 1968 (1959). 'Myths about Arabic'. In Readings in the Sociology of Language, edited by J. Fishman, 375-81. The Hague: Mouton.

Foucault, Michel. 1978. 'La gouvernementalité'. Dits et écrits III: 635-57. Paris: Gallimard.

Gal, Susan. 2005. 'Language Ideologies Compared: Metaphors of Public/Private.' Journal of Linguistic Anthropology 15 (1), 23-37.

Horrocks, Geoffrey. 1997. Greek: A history of the Language and Its Speakers. London: Longman.

Inalcik, Halil, and Donald Quataert (eds). 1994. An Economic and Social History of the Ottoman Empire. Cambridge: Cambridge University Press.

Leezenberg, Michiel. 2016. 'The Vernacular Revolution: Reclaiming Early Modern Grammatical Traditions in the Ottoman Empire'. History of Humanities 1 (2): 251-75.

—_ 2014. 'Elî Teremaxî and the Vernacularization of Medrese Learning in Kurdistan'. Iranian Studies 47: 713-33. 
_ 2021. 'Internalized Orientalism or World Philology? The Case of Modern Turkish Studies'. History of Humanities 6 (1): 109-19.

Mackridge, Peter. 2009. Language and National Identity in Greece, 1766-1976. Oxford: Oxford University Press.

Mardin, Serif. 1961. 'Some Notes on an Early Phase in the Modernization of Communications in Turkey'. Comparative Studies in Society and History 3 (3): 250-71.

Nichanian, Marc. 1989. Ages et usages de la langue arménienne. Paris: Éditions Entente.

Pollock, Sheldon. 2000. 'Cosmopolitan and Vernacular in History'. Public Culture 12: 591-625. 



\title{
2. FROM MEANS TO GOAL: AUXILIARY DISCIPLINES IN THE OTTOMAN MADRASA CURRICULUM
}

\author{
Necmettin Kızlkaya
}

\subsection{Introduction}

The Ottoman Empire established madrasas since its formation. It met the needs of these madrasas, first, by inviting teachers from adjacent regions and, soon after, by employing their students. Thus, students who successfully graduated from the madrasa then became the teachers, who would in turn become the pioneers in systemising the Ottoman madrasa (Āşıkpaşazāde 1332). The curriculum became methodised in a short time. To ensure the continuation of this system, it was continually revised and developed by the Ottoman scholars.

There were many factors that facilitated this constant revision of the Ottoman madrasa system. The most important of these was that the madrasa was an institution in which qualified individuals were produced in every area needed by the Empire. The madrasa curriculum, which had been structured to respond to a wide range of expectations and issues, from bureaucracy to ilmiye institutions, had to be continually developed. That being said, the effort to develop the curriculum does not mean that there were 
no fixed disciplines within the madrasa system. On the contrary, in some fields there were books that were taught for centuries throughout the Empire. Therefore, there were constants and variables in the madrasa curriculum; and the variables were shaped according to the needs of each period.

Despite this, we still do not have much knowledge about the books taught in the Ottoman madrasa system, as there has not yet been much scholarly attention by researchers in the field of history and education on the subject. Studies regarding the madrasa mainly focus on its structures, its architecture, its relations with politics, teacher-student relationships, and ilmiye hierarchy. Many issues, such as the curriculum, the range of the courses taught, the differences encountered within different regions, and the reasons for changes to the curriculum have not been elucidated as of yet. The absence of specific scholarship regarding this subject in Western languages, with the exception of a few general studies, has led to a lack of understanding regarding the nature of the Empire's educational system among modern researchers. Although some Turkish studies partially fill the gap on this subject, ${ }^{1}$ a significant number of them provide only general information about the curriculum, and more detailed studies are needed.

The Ottoman madrasa curriculum was structured in different stages, with different disciplines taught at each step. The main aim of the curriculum was to understand the Islamic disciplines and to meet the needs of society. Therefore, the madrasa

\footnotetext{
${ }^{1}$ For details see Hüseyin 1983; İsmail 1984; Cevat 1997; Murat 2019.
} 
curriculum focused on understanding three disciplines. These disciplines are fiqh 'deep understanding', kalām 'theology', and tasawwuf 'mysticism', which are called al-'ulūm al-'ālìya 'the high disciplines'. However, the discipline of fiqh stands in a central place among them. It is not an exaggeration to posit that the madrasa education was designed for the discipline of fiqh. There was a preparatory process that trained students for these three disciplines, in general, and fiqh, in particular. In this process, the auxiliary disciplines, which are 'ulüm äliyya, were taught and the students were provided with the necessary knowledge and sophistication to understand the Islamic disciplines. The preparatory/auxiliary disciplines are mostly Arabic disciplines. The auxiliary disciplines, which serve as the key for students to comprehend texts written in various branches of the Islamic disciplines that emerged in Muslim societies, especially the texts of the Qur'ān and the Sunna, are sarf 'morphology', nahw 'grammar/syntax', manțiq 'logic', ādāb al-bahth wa-l-munāzara 'dialectic', waḍ ' 'philosophy of language', and balāgha 'rhetoric'.

There are many classical sources about the disciplines taught in Ottoman madrasas. Both the divergent sources and the teaching of various works in different centuries in the Empire, which lasted for six centuries, make it difficult to draw a unified picture of the curriculum. However, the fact that the disciplines taught did not undergo much change in these periods, together with the continuity of some of the utilised texts, allows us to make general comments on some points. Three types of sources are available to investigate the taught courses. The first of these 
are books dealing with the tartib 'organisation' and tasnif 'classification' of disciplines. I will examine the curriculum based on these sources. The second of these are biographies and autobiographies of scholars. In these sources, the books that a scholar read and taught give a particular idea to the reader about which books were in circulation, accepted, and included in to the curriculum. The third type are ijāza 'diplomas'. These diplomas reveal to us the lessons and from whom those lessons were taken. Yet, in general, they do not mention the names of the books studied. In this article, I will briefly examine the works taught in the field of auxiliary disciplines in the Ottoman madrasa curriculum. Although different works were taught in different periods and regions, I will focus on the most widely read books.

\subsection{Auxiliary Disciplines in the Madrasa}

\section{Curriculum}

Kawākib-i Sab'a Risālesi is an anonymous work authored in $1155 / 1741$ as a response to an inquiry by the French ambassador to Bāb-i Ali (High Porte) about the character of the Ottoman madrasa curriculum. It consists of important material regarding the pre-madrasa education. I will briefly summarise the information about the pre-madrasa process in the risāla. According to this risāla, upon starting his education, a student first learned the Arabic alphabet and then began reading the Qur'ān from 'amma juz'. ${ }^{2}$ Then, under the supervision of a teacher, the student would

\footnotetext{
${ }^{2} \mathrm{~A} j u z^{\prime}$ is one of the thirty parts of the Qur'ān.
} 
read the whole Qur’ān along with a book of tajwid. ${ }^{3}$ Later, the process continued with memorising the Qur'ān and Birgili Mehmed Efendi's (d. 981/1573) 'Aqā’id Risālesi, which was written in Turkish. After the ceremony of completing the memorisation of the Qur'ān, a dictionary—such as the poetic dictionary of Ibn al-Farishta (d. after 821/1418)—was taught to impart familiarity with Arabic words. Additionally, in order to get used to Persian, brāhīm Shāhidī's (d. 957/1550) Persian verse dictionary Tuhfa-i Shāhidī ) was taught. Having completed this process, the student was able to begin the auxiliary disciplines (Cevat 1997). The disciplines taught in the madrasa were divided into three main parts: the auxiliary disciplines, Islamic disciplines, and juz'iyyāt 'particular cases, details', such as mathematics, geometry, and astronomy). The main purpose was to learn the Islamic disciplines; the auxiliary disciplines were taught in support of understanding them. Of course, this never demoted the auxiliary disciplines to a secondary position. On the contrary, in some periods and madrasas, they were given equal importance to the Islamic disciplines.

\subsection{Morphology (Ṣarf)}

The first discipline taught in auxiliary disciplines was the discipline of morphology (șarf). The Amthila (Amthila-i Mukhtalifa waMuttarida) was the first book read in this discipline. This text examines words and their forms. The students first memorised the text. An interesting feature of this text is that it is an anonymous

\footnotetext{
${ }^{3}$ Tajwid is a set of rules for the correct pronunciation of the letters with all their qualities.
} 
text/or that its author is unknown. After this, Binā' al-af' $\bar{a} l$, also anonymous, was studied. This book was written to afford basic knowledge of morphology based on the sound, structure, and semantic variation of the past and present tenses of Arabic verbs. In this respect, the basic education given in Amthila is deepened

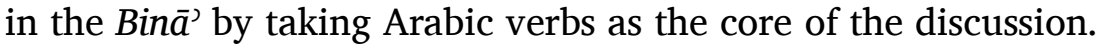
The Maqșūd, which is read at the next stage, is, like Amthila and Bina $\bar{a}$, also anonymous. In this book, after emphasising the importance of the discipline of morphology, the patterns of verbs, conjugations of verbs and the declension of nouns, the rules to be applied in these conjugations and declensions and their explanations are all expounded upon and the kinds and descriptions of the verbs are elucidated (Khalifa 2007, 1:255; 2:1078, 1806-7).

$A l$-Izzi fi l-tasrif is one of the five classical works known as the sarf cümlesi and taught in the Ottoman madrasas. It is an important book written by 'Izz al-Dīn al-Zanjānī (d. 660/1262) on the discipline of Arabic morphology. Because of its importance, scholars like Sacd al-Dīn al-Taftāzānī (d. 792/1390), Sayyid Sharīf al-Jurjānī (d. 816/1413), 'Imād al-Dīn Ibn Jamā'a (d. 819/1416), Niksārī Ḥasan Pasha (d. 827/1424), Khoja Zāda Muslih al-Dīn (d. 893/1488), Khatīb al-Shirbīnī (d. 977/1570), and 'Ali al-Qārī (d. 1014/1605) have written commentaries on it. Among them, the commentary by Taftāzānī became famous and dozens of sub-commentaries were written on it (Khalifa 2007, 2:1139-40). Like other books of morphology, Ahmad b. 'Alī b. Mas'ūd's (d. 8th/14th century) comprehensive work Marāh alarwāḥ was widely taught in Ottoman madrasas. This book consists of seven chapters and provides detailed information first on 
infinitives and then on the different forms and types of verbs (Khalīfa 2007, 2:1651).

Ibn al-Hājib's (d. 646/1249) al-Shāfiya fì l-Tașrîf, was written on Zamakhsharī's (d. 538/1144) al-Mufașsal fi șan'at al-i'rāb, which is a summary (khulāsa) of Abū Bishr Sībawayhi's (d. 180/796) al-Kitāb. This was a key text in morphology within the madrasa curriculum. Ibn al-Ḥājib combined the subjects related to morphology in Zamakhsharī's al-Mufașsal by making the necessary additions as well as sorting, correcting, and summarising them in his al-Shafiya. This book is considered the first concise work on morphology, covering almost all subjects of the discipline. Another significant feature of this text was that the author, Ibn al-Hājib, though based in an Ottoman and Hanafi tradition madrasa, was a Mālikī scholar. Al-Shāfiya explains the rules of morphology in a concise yet systematic way. It has been taught as a textbook for centuries in madrasas throughout the Ottoman and Islamic world. Many studies from commentaries, sub-commentaries, poeticisation, and translation have been added to it. Moreover, not only the text itself, but also its commentaries were taught in the Ottoman madrasas (Khalīfa 2007, 2:1021).

\subsection{Grammar/Syntax (Naḥw)}

The second discipline taught was Arabic grammar/syntax (nahww). The first book that was used as a textbook in Arabic grammar was the 'Awāmil. Although there were several books that bore this title, two of them were widely used for teaching in the Ottoman madrasas over the centuries. The first one was 'Abd al-Qāhir bin 'Abd al-Raḥmān al-Jurjānī’s (d. 471/1078) al-`Awāmil, which 
was called al-'Awāmil al-'atiq; the second one was Muhammad Birgiwī's (d. 981/1573) al-'Awāmil, which was referred to as al'Awāmil al-jadìd. However, there are significant differences between these two books in terms of a number of factors (' $\bar{a}$ mils) and the way they were treated. Al-Jurjānī's al-'Awämil was taught in some parts of Anatolia, though mainly in Arab regions, Iran, and the Indian Subcontinent. As for Birgiwì's text, it was taught in the madrasas of Istanbul and the Balkans for a long period (Durmuş 1991). After memorisation of Birgiwī's al-'Awāmil, students moved to another book, Iẓhär al-asrār, which was written based on the principles of the Basran language school of grammar, i.e., to teach the main subjects of Arabic grammar in a concise way and in a short time. The grammatical rules that were mentioned only by name and with a single example in the 'Awāmil were extended in Iz̧här al-asrār by giving their definitions, conditions, and detailed examples (Khaliffa 2007, 1:117).

Ibn al-Hājib's al-Käfiya is one of the main texts that was used in the Ottoman madrasas. It is, along with Sībawayhi's alKitāb and Zamakhsharī's al-Mufașal, one of the three most recognised books written on Arabic grammar. Although Sībawayhi's al-Kitāb contains rich material and examples, its contents are unclassified. Zamakhsharī classified its subjects and summarised it in his al-Mufașsal. Ibn al-Hājib's al-Kāfiya relied on al-Mufașșal. All of the subjects of nahw were studied to allow students to understand complex topics. Thanks to the accomplishment of alKăfiya, it was used as a text book in Ottoman madrasas for centuries (al-Zamakhsharī 2004; Khalīfa 2007, 2:1370-76). Ibn alHâjjib's al-Kāfiya was used not only as an independent textbook 
in the madrasa curriculum, but also as the main text and subject of commentary by Nūr al-Dīn 'Abd al-Raḥmān Jāmī's (d. 898/1492) al-Fawā’id al-Dhiyā’iyya. Al-Fawā’id, which is also known as Jāmi or Molla Jāmi. It was one of the main grammar books that was taught at the advanced level. Molla Jāmi was not the only advanced textbook that students studied in madrasa; other books were also taught, such as Ibn Hishām's (d. 761/1360) Mughnì al-labīb and Alfiyyat Ibn Mālik (Ibn Khaldūn 2005, 5:29798).

Besides some other features, Mughni al-labib is original in terms of its classification of subjects. By that time, grammar books had come to classify subjects based on 'āmil-ma'mūl-i'rāb, marfü 'āt-mansūbāt-majrūrāt-majzūmāt, but Ibn Hishām followed a different method, which made his book renowned and one of the most circulated since his time. He divided its eight sub-chapters into two main chapters, which are mufradāt 'propositions' and jumal 'sentences' (Ibn Hishām 1964; Khalīfa 2007, 2:1751-54). As for the Alfiyyat Ibn Mālik fi l-naḥw wa-l-tașîf, it was composed of thousands of grammatical rules explained using examples from Qur'ānic verses, Prophetic traditions, and Arabic poems. It was memorised by students at the advanced level (Khalifa 2007, $1: 151-55)$.

\subsection{Logic (Manțiq)}

After completing grammar, students would study logic (manțiq). Most of the mantiq books taught in Ottoman madrasas belonged to the last period of the pre-Ottoman era, which is denominated 
the muta'akhkhirūn period. The first textbook taught in the madrasa on logic is Asīr al-Dīn al-Abharī's (d. 663/1265), al-Risāla alAțiriyya fì l-manțiq, with a condensed version known as İsāgūcī, along with its commentaries and the glosses written on it. İsāgūci is an abridgement that contains all the subjects of classical logic. Because of this feature, it became the first textbook taught in the discipline of logic in the madrasa curriculum and many commentaries and sub-commentaries written on it have received the attention of scholars. The first of these commentaries is Husam alDīn Hasan al-Kātī's (d. 760/1359) Ḥusam-i Kātī and Muhy al-Dīn al-Tālishī's (d. 887/1482) sub-commentary on it are famous. Mullā Fanārī's (d. 834/1431) al-Fawā'id al-Fanāriyya, which is the second well-known commentary, and its sub-commentary, Ahmmad Ibn Khizir's (d. 950/1543) Qūl (Qawl) Ahmad, were also central textbooks in the madrasas (İzgi 1997). These two books differ from the other logic books taught in the madrasa in the way that both, especially the latter, employ tight and comprehensive language. By reading these texts, the student not only learned logic, but also had to grapple with difficult phrases of the Arabic language.

At a higher level, students were taught 'Alī Ibn Omar alKātibī al-Qazwīnī's (d. 675/1277) al-Risāla al-Shamsiyya fì lqawā'id al-manțiqiyya and Sa'd al-Dīn al-Taftāzānī's Tahdhīb almanțiq wa-l-kalām, with its commentaries and super commentaries. In the following period, Qutb al-Dīn al-Rāzī's (d. 766/1365) Tahrīr al-qawā'id al-manțiqiyya fì sharḥ al-Risāla alShamsiyya, a famous commentary on al-Qazwīnī's al-Risālat al- 
Shamsiyya, was taught. Along with Taḥrì al-qawā'id al-mantiqiyya, its sub-commentaries in Sayyid Sharīf al-Jurjānī's (d. 816/1413) Tahrīir al-qawā'id and in Kara Dāwūd Izmitī's (d. 948/1541) Hāshiya 'alā Hāashiya Küçük (Kuçek) 'alā Tahrīr alqawā'id al-manțiqiyya were studied. The student who read and completed these books proved his scientific talent and desire. Finally, in the discipline of logic Qutb al-Dīn al-Rāzì's commentary, Lawāmi` al-asrār Sharh Mațāli` al-anwār fi l-manțiq on Sirāj al-Dīn al-'Urmawī’s (d. 682/1283) Mațāli` al-anwār, was taught (al-Rāzī 1384; Sāçaklīzāde 1988).

\subsection{Dialectic (Ādāb al-baḥth wa-l-munāzara)}

After logic, dialectic (ādāb al-bahth wa-l-munāzara) was studied to help students avoid inconsistency and contradiction in debate. At the elementary level, Taşkuprizāde Aḥmed Efendi's (d. 968/1561) Sharh 'alā Risāla fì 'ilm ādāb al-baḥth wa-l-munāzara, which is his commentary on his own al-Risāla, was taught. After that, students studied Kamāl al-Dīn Mas'ūd al-Rūmī's (d. 905/1499) commentary on Shams al-Dīn Muhammad Ibn Ashraf al-Samarqandī's (d. 722/1322) al-Risāla al-Samarqandiyya fì ādāb al-bahth, which has around twenty-one super commentaries. At the same time, they were studying Shah Husayin Efendi's (d. 1130/1718) al-Risāla al-Husayniyya fi fanni ādāb al-baḥth with its commentaries and sub-commentaries . Following this stage, students studied Qādī 'Aḍud al-Dīn al-ījī's (d. 756/1355) Ādāb albaḥth and its commentary Sharḥ Ādāb al-baḥth, written by Muhammad al-Ḥanafī 1-Tabrīzì (d. around 900/1494) and its sub- 
commentary, Mīr Abū al-Fatḥ Muḥammad Ibn Amīn's (d. around 875/1470) Hāàshiyat al-Mìr (İzgi 1997).

\subsection{Philosophy of Language (Wad)}

One of the important disciplines taught in madrasas was 'ilm alwad'. Wad ' , which deals with the origins and nature of language, focuses on the relationship between utterance and meaning and the circumstance/state of indication of utterance to meaning. The subjects of wad', whose history did not go as far back as that of other disciplines, were examined in the context of the relationship of utterance and meaning in the works of philology, logic, and legal theory before becoming an independent discipline. 'Aḍud al-Dīn al-İjī's al-Risāla al-waḍ'iyya is the first independent work written on the relationship of words and meaning by focusing on the wad'c. Al-Risāla al-Wad'iyya became famous soon after it was written, and many commentaries and sub-commentaries were written on it. The discipline of al-wad̆ reached a certain depth due to discussions between $S^{c}{ }^{c}$ al-Dīn al-Taftāzānī and Sayyid Sharīf al-Jurjānī, in particular on the relationship between utterance and meaning. Alī Kuşçī's (b. 879/1474) 'Unqūd alzawāhir fi l-ṣarf systematised waḍ' and changed its subjects, shifting the focus from utterance meaning to wad ${ }^{\varsigma}$. The subjects were

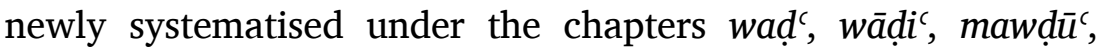
mawḍ $\bar{u}^{`} l a h u$, and hikma al-waḍ and were made more advanced. In this way, the process which deals with language from a philosophical perspective was followed at various stages in numerous texts throughout the Ottoman Empire (Kuşçī 2001; Fazlığlu 2012). 
In the discipline of al-wad', whilst commentaries and glosses were being written within Ottoman lands, so too were independent works being written and taught within the madrasa. The first commentary on al-İjī's al-Risāla al-Waḍ 'iyya was Abū alQāsim al-Laythī al-Samarqandī's (d. 888/1483) Sharh Risāla alWad'iyya. It was one of the main texts taught in the Ottoman madrasa. Another commentary written on al-Risāla al-Waḍiyya and taught in the Ottoman madrasa was 'Ișām al-Dīn alIsferāyīnī's (d. 951/1544) Sharh Risāla al-Waḍ'iyya, which was known in madrasa circles as 'Ișām al-waḍ' or 'Ișām al-waḍ'iyya. This commentary by al-Isferāyīnī was usually taught with the commentary of al-Samarqandī, but found comparatively more space in the curriculum relative to that book. Another work that was studied in this field was Risāla fi l-wad'c, which was penned by Ibrāhīm Ibn Khalīl al-Agīnī (d. 1311/1894), who lived in the last period of the Ottoman Empire (Özdemir 2006, 203, 206, 212; Khalifa 2007, 1: 898).

\subsection{Rhetoric (Balägha)}

Rhetoric (balägha) examines the rules and methods of mot juste and proper speech. It examines the pronunciation of the word in a clear, understandable, and beautiful manner in accordance with the situation required by the interlocutor. It is divided into three sub-sections: 'ilm al-ma'ānī 'semantics', 'ilm al-bayān 'figures of speech', and 'ilm al-badī 'embellishments'. Rhetoric as a discipline is as old as morphology and syntax. This discipline emerged and was developed in order to cultivate appreciation of the style 
and subtle meanings of the Qur’ān (al-Qazwīnī 1932, 36-37; alSakkākī 1987, 161-62).

In the Ottoman madrasa, Muḥammad Ibn 'Alī al-Sakkākī's (d. 626/1228) Miftāh al-ulūm was the main text taught. The third part of this work-which examines various disciplines, such as morphology, syntax, poetry-bears the title 'ilmā al-ma'āni wa-lbayān. In this chapter, Sakkākì expands on the discipline of rhetoric as a discipline, using rational methods of knowledge that were employed in the fields of theology, philosophy, and logic. With this approach, he transformed rhetoric from being an individual experience and pleasure to a discipline with its own rules and principles. In this respect, Sakkākī introduced an innovation no one else initiated before him, and seriously influenced those who came after. Therefore, Miftāh al-'ulūm was the basis for almost all of the books written on balāgha (Ibn Khaldūn 2005).

Khatịib al-Qazwīnī's (d. 739/1338) al-Talkhìs fì 'ulūm albalagha comes first among the books taught in the discipline of rhetoric, which has an important place in the madrasa curriculum. This book, which is the summary of Sakkākī's Miftāḥ al'ulūm, is still read in the discipline of rhetoric in today's madrasas. Because of its importance, numerous studies have been made on Khațīb al-Qazwīnī's al-Talkhīs. Among these studies, two commentaries written by Sa'd al-Dīn al-Taftāzānī are especially important. Of these, al-Sharh al-Mukhtașar was short and taught after al-Talkhis in Ottoman madrasas. He wrote the second commentary, al-Sharh al-Muțawwal, after examining the books written in the discipline of rhetoric, especially Abd al-Qāhir alJurjānī's (d. 471/1079) Dalā’il al-ijjāz and Asrār al-balāgha (al- 
Taftāzānī 2013). In some madrasas, instead of al-Mutawwal, Khațīb al-Qazwīnī's İdāh al-ma'ānī which is the author's own commentary on the al-Talkhìs fì 'ulūm al-balāgha was studied. In some madrasas, as a final book, Burhān al-Dīn Ibrāhīm Ibn Muhạmmad al-Halabī al-Qabāqibī's (d. 850/1446) al-Alfiyya li lma‘ānī wa-l-bayān was memorised (İzgi 1997).

\section{References}

Āşıkpaşazāde. 1332. Tevārih-i Āl-i Osman'dan Āşılkpaşazāde Tarihi. Istanbul: Matbaayı Āmire.

Atay, Hüseyin. 1983. Osmanlılarda Yüksek Din Eğitimi: Medrese Programları, İcazetnāmeler, Islahat Hareketleri. Istanbul: Dergah Yayınları.

Çelik, Murat. 2019. Osmanlı Medreseleri ve Avrupa Üniversiteleri (1450-1600). Istanbul: Küre Yayınları.

Durmuş, Ismail. 1991. 'El-'Avāmilü'l-mie'. In Turkiye Diyanet Vakfi Islam Ansiklopedisi. Istanbul: Turkiye Diyanet Vakfi Yayinlari.

Fazlıoğlu, Şükran. 2012. 'Vaz'. In Turkiye Diyanet Vakfi Islam Ansiklopedisi. Istanbul: Turkiye Diyanet Vakfi Yayinlari.

Ḥajī Khalīfa, Kātib Çelebi. 1972. Kashf al-ẓunūn 'an asāmī al-kutub wa-al-funūn. Baghdād, Maktabat al-Muthannā.

Ibn Hishām, 'Abd Allāh ibn Yūsuf. 1964. Mughni al-labỉb 'an kutub al-a'ārīb. Cairo: al-Maktabah al-Tijārīyzh al-Kubrā.

Ibn Khaldūn, 'Abd al-Raḥmān. 20005. Al-Muqaddimah. Casablanca: al-Dār al-Bayḍā’ .

İzgi, Cevat. 1997. Osmanl Medreselerinde İlim I-II. Istanbul: İz Yayıncılık. 
Kuşçī, 'Alī. 2001. 'Unqūd al-zawāhir fì l-ṣarf. Cairo: Dār al-Kutub al-Mișriyya.

al-Qazwīnī, Jalāl al-Dīn Muḥammad ibn 'Abd al-Raḥmān. 1932. al-Talkhịs fì 'ulūm al-balāghah. Miṣr: al-Mațba‘ah alRaḥmānīyah.

al-Rāzī, Qutb al-Dīn. 1384. Taḥīr al-qawācid al-manțiqiyya fī sharḥ al-Risālat al-Shamsiyya. Qum: Manshūrāt Baydar.

Sāçaklīzāde, Muhammad b. Abī Bakr. 1988. Tartỉb al-‘ulūm. Beirut: Dār al-Bashā'ir al-Islāmiyya.

al-Sakkākī, Yūsuf ibn Abī Bakr. 1987. Miftāḥ al-‘ulūm. Beirut: Dār al-Kutub al-Ilmiyya.

al-Taftāzānī, Sa`d al-Dīn. 2013. al-Muțawwal harh Talkhīs Miftāh al-'ulūm. Beirut: Dār al-Kutub al-'Ilmiyya.

Uzunçarşılı, İsmail Hakkı. 1984. Osmanlı Devletinin İlmiye Tekilātt. Ankara: Türk Tarih Kurumu Basımevi. 


\title{
3. ON THE ORDER OF THE SCIENCES FOR HE WHO WANTS TO LEARN THEM
}

\author{
Guy Burak
}

Muḥammad ibn Abī Bakr Sājaqlīzādah (Saçaklızade, d. 1732/3) was an influential scholar who devoted a work to the organisation of the Islamic sciences (titled accordingly Tartib al-culüm, completed ca. 1715). ${ }^{1}$ The following passage is the section from this work in which he discusses the training of a scholar. Interestingly, Sājaqlizādah is aware of the different linguistic backgrounds of the students across the Empire and structures the curriculum, which consisted primarily of texts in Arabic, accordingly. It is for this reason that he insists on the memorisation of the Arabic-Turkish dictionary by Ibn Malak (or Ibn Firishta).

Confidence that he is capable of understanding [the material] should be instilled in the novice. If he is young (șabiyan), he should be ordered to study the Qur'ān with a teacher whose transmission [of the Qur'ān] is sound, until he completes [the study of the entire Qur'ān]. Then he should be ordered to study the minutiae of faith, the principles of the creed of the People of the Sunna, the prescribed ability [to comprehend] the science of ethics and the science of prayer.

\footnotetext{
${ }^{1}$ On Saçaklızade see Özcan (2005); El-Rouayheb (2015, 116-20).
} 
He who masters (mutakaffil) all those [sciences should study] Muhammad Birgivi's Turkish Epistle, ${ }^{2}$ which is easy for novices who are not speakers of Arabic ('ajami). ${ }^{3}$ Then he should be ordered, if he is a non-speaker of Arabic, to study Lughat Ibn Firishta ${ }^{4}$ and memorise it. If he is mature (bāligh), after [gaining] confidence in his ability to comprehend [the materials], he should be ordered to study [Surat] al-Fätiha and short suras. Then he should be ordered to study that [i.e., Birgivi's] Epistle or any [other epistle] that will be of use. Then he should be ordered to study the entire Qur'ān. Then he should be ordered to study Lughat Ibn Firishta and memorise it. After having studied Lughat Ibn Firishta, be he young or mature, he should be ordered to study the science of morphology (sarf), then grammar (nahw), then [jurisprudential] practical rulings ('ilm alahkām), then logic, then disputation (munāzara), then theology (kalām), then rhetoric (ma'ānì), then the fundamentals of jurisprudence and then jurisprudence. By 'jurisprudence' I do not mean only the science of practical rulings (al-ahkkäm al-'amaliyya) without evidence [for this judicial opinion], as in Mukhtasar al-Qudūri ${ }^{5}{ }^{5}$ but the understanding of [jurisprudence] with [jurisprudential] evidence, as in alHidāya. ${ }^{6}$ As for Mukhtasar al-Qudūrī, or whatever replaces it in the science of practical rulings, he should study it after

\footnotetext{
${ }^{2}$ Birgivi (1898), and Birgivi (1876).

3 'Ajami can mean 'Persian' or 'speaker of Persian', though in this context it seems to be a generic term referring to non-Arabic speakers.

4 (Izz al-Din 'Abd al-Lațîf ibn Malak's (also known as Ibn Farishta or Firişteoğlu, d. After 1418) was one of the first Arabic-Turkish dictionaries; see Baktır (1999).

${ }^{5}$ Al-Qudūrī (2005).

${ }^{6}$ Al-Marghīnānī (2000).
} 
having studied the science of phonetic forms and grammar. Otherwise, his understanding will remain [at the level of] the principles ( $q a w \bar{a}(i d)$ of Fundamental of Jurisprudence, unlike the understanding [required for texts] like alHidāya. By 'theology' I do not mean only the theological issues (al-masā’il al-i'tiqādiyya), but what appears [in works] like al-Maqāsid ${ }^{7}$ on essences (jawāhir) and attributes ( $\left.a^{c} r \bar{a} d\right)$ and theological issues with proofs and responses to opponents. Then, after [having studied that] he should study the principles of hadith, then hadith riwaya, and hadith dirāya, and then Qur'ānic exegesis. As for the study of Qur'ānic recitation (tajwìd) and the Qur'ānic readings (qirā'āt) and Qur'ānic orthography (marsūm almașāhif), the student should learn [these sciences] whenever he can, before studying Qur'ānic exegesis. As to arithmetic, geometry, astronomy, and the science of metres and rhymes, he should study them whenever he can, but it is recommended to study arithmetic before the study of practical rulings and especially [before the study] of inheritance rules $(\text { farā'id })^{8}{ }^{8}$

\section{References}

Baktır, Mustafa. 1999. 'İbn Melek'. Türkiye Diyanet Vakfi İslâm Ansiklopedisi 20: 175-76.

Birgivi, Mehmet. 1876. Risale-i Birgivi. Istanbul (?). 1898 [1314]. Vasiyetname. Istanbul (?).

El-Rouayheb, Khaled. 2015. Islamic Intellectual History in the Seventeenth Century: Scholarly Currents in the Ottoman Empire and the Maghreb. New York: Cambridge University Press.

\footnotetext{
${ }^{7}$ Al-Maqāṣid (1989); see also Özen (2011).

${ }^{8}$ Sajaqlizādah (Saçaklızade) (1988, 209-10).
} 
al-Marghīnānī, 'Alī ibn Abī Bakr. 2000. Al-Hidāya: Sharḥ Bidāyat al-Mubtadiī. Cairo: Dār al-Salām li-1-Ṭibā'a wa-l-Nashr.

Özen, Şükrü. 2011. 'Tetazani'. Türkiye Diyanet Vakfi İslâm Ansiklopedisi 40: 299-308.

Özcan, Tahism. 2008. 'Saçaklızade Mehmed Efendi'. Türkiye Diyanet Vakfi İslâm Ansiklopedisi 35: 368-70.

al-Qudūrī, Aḥmad ibn Muhammad al-Qudūrī. 2005. Mukhtașar. Beirut: Mu’assasat al-Rayyān li-1-Ṭibāca wa-l-Nashr wa-1Tawzīं.

Sajaqlizādah (Saçaklızade), Muhammad ibn Abī Bakr alMar'ashī. 1988. Tartīb al-'Ulūm. Beirut: Dār al-Bashā'ir alIslāmiyya.

Taftāzānī, Mas'ūd ibn 'Umar.' 1989. Kitāb Sharḥ al-Maqāṣid. Beirut: '`Ālam al-Kutub. 


\title{
4. RUMI AUTHORS, THE ARABIC HISTORIOGRAPHICAL TRADITION, AND THE OTTOMAN DAWLA/DEVLET
}

\author{
Guy Burak
}

In Jumādā II 965/April 1558, the envoy of the sharif of Mecca, the Hanafi jurist, scholar, and chronicler Quțb al-Dīn Muhammad b. Aḥmad b. Muḥammad al-Nahrawālī (d. 1582) visited Istanbul and met with Semiz Ali Paşa, then second vizier and future grand vizier of the Empire (served as grand vizier from 1561 to 1565). ${ }^{1}$ The Meccan envoy was impressed by the vizier's scholarly interests and, particularly, by the latter's interest in history (ta'rikh). When the vizier informed the envoy of his successful military campaigns against the infidels, al-Nahrawālī warned the vizier:

if what you have mentioned is not recorded, it will perish from memory and its virtues will not be known after a few years, and when whoever was present in that campaign perishes, his narration [of events, khabar] will perish as well. No one will remember [the campaign] and its

\footnotetext{
${ }^{1}$ On al-Nahrawālĩ see Blackburn (2012). See also the Introduction in Blackburn (2005). On Semiz Ali Paşa, see Mantran (2012). AlNahrawāli left two reports of this encounter: in his travelogue (Blackburn 2005, 168-69) and in his chronicle; for the latter see al-Nahrawāli (2004, 310-11).
} 
knowledge will vanish from the pages of existence (șafahăt al-wujūd) after a short while.

The Meccan envoy immediately mentioned the interest of Arab scholars ('ulam $\bar{a}^{\prime}$ ) in the science of history and even provided the vizier with a relevant example: the 13th-century chronicler Abū Shāma's (d. 1267) al-Rawḍatayn fì akhbār al-dawlatayn (Abū Shāma 1997). Abū Shāma's chronicle, al-Nahrawālī explained, records the military campaigns against the crusaders undertaken during the reigns (dawla) of Nūr al-Dīn (d. 1174) and Șalāh alDīn al-Ayyūbī (d. 1193). "This most exquisite and beautiful book," the Meccan pointed out, "remained in the pages of time." Al-Nahrawālī then concluded with a question: "Why aren't your histories (akhbārakum) and deeds (äthärakum) recorded in the books [of history], eternalised in the pages of the eras and time periods?" Upon hearing the envoy's question, Semiz Ali Paşa asked the scholar and jurist Kınalızade Ali Çelebi (d. 1572), whom al-Nahrawālī described as "the time's most virtuous composer in Arabic" (fadill dhalika al-waqt fì al-inshä al-`Arabì), to compile a work like Abū Shāmah's. According to al-Nahrawālī, Kınalızade started working on the Arabic chronicle, which he never completed (Al-Nahrawālī 2004, 310-11). ${ }^{2}$

${ }^{2}$ On Kinalizade see Tezcan (1996) and Köker (1999). Kinalizade's familiarity with the Arabic scholarly traditions may have been one of the reasons for his eventual appointment, in 1562, to the chief judgeship of Damascus. On his encounters with the Damascene scholars see Pfeifer (2015). 
The vignette is revealing for several reasons. First, the exchange between the three protagonists reveals intriguing dynamics between the different parts of the Empire and their respective intellectual/historiographical/literary traditions. Al-Nahrawālī, a Meccan jurist and scholar, was well-versed in the Arabic historiographical tradition. The vizier, who was of Bosnian descent and had entered the imperial administration as a young boy, on the other hand, was known for his patronage of at least two works in 'simple Turkish' over the course of his career: a short treatise on the Ottoman construction projects in Mecca, which he commissioned during his tenure as governor of Egypt, and the Book of Prayer ( $d u^{\prime} \bar{a}$-nāme), which he commissioned during his grand vizierate. ${ }^{3}$ And Kinalızade, "the most virtuous writer in Arabic [among the Rumis]," emerges as one of the relatively few scholars from the core, predominantly Turkish-speaking lands of the Empire sufficiently familiar with the Arabic historiographical tradition to compile a chronicle like Abū Shāma's.

Secondly, al-Nahrawālī's comment on the state of Ottoman historiography merits attention. By the mid-16th century, when al-Nahrawālī visited the Ottoman capital, numerous chronicles devoted to the history of the Ottoman dynasty had already been written. ${ }^{4} \mathrm{Al}-\mathrm{Nahrawāli}$ clearly misrepresented the state of histor-

${ }^{3}$ For the treatise on the Ottoman construction projects see Burak (2017, 315 n. 2). On the Du'a-name, which was authored by the famous chief mufti Ebu's-Su'ud Efendi (d. 1574), see Kaleli (2014).

${ }^{4}$ The literature on 15th-century historiography in the Ottoman lands is quite vast. See, for instance, Mengüç (2013) and the bibliography 
ical writing in the core lands of the Empire. His implicit observation, however, that few historical works were written in Arabic in the core lands of the Empire, was quite accurate, as most historical works were compiled in Ottoman Turkish and Persian. But assuming that both the Meccan envoy and the vizier knew about the historiographical corpus in Turkish (and Persian), the former's statement about the lack of historical writing, presumably in Arabic, in the core lands of the Empire implied a hierarchy between the Arabic and Turkish historiographical traditions: it was only historical writing in Arabic, according to al-Nahrawālī, that was truly eternal. This was obviously a view of a scholar versed in the Arabic historiographical tradition. But in the second half of the 16th century, several scholars and chroniclers from the core lands of the Empire (known as Rumis, 'from the Land of Rum' $)^{5}$ followed in Kinalızade's footsteps and were receptive to this view of historical writing.

The differences between the historiographical traditions that coexisted throughout the empire were more than simply a matter of language. Each historiographical tradition employed conceptual and stylistic conventions that were not easily translatable. The emergence of a Rumi Arabic historical writing in the second half of the 16th century was also intended to provide the Ottoman ruling and administrative elite with a vocabulary to le-

therein. See also the section on historical writings in the palace library of Bayezid II: Fleischer and Şahin (2019, 569-96).

${ }^{5}$ On 'Ruminess' see Kafadar (2007). 
gitimise their rule over the newly conquered Arabic-speaking territories of Greater Syria, Egypt, the Hijaz, and, slightly later, Arab Iraq.

This essay seeks to focus on one of these conventions: the Arabic expression al-Dawla al-'Uthmāniyya. This expression, I would like to suggest, was embedded in the Arabic historiographical tradition, but was quite alien to the Turkish (and Persian) ones. It is for this reason that this expression opens a window into broader dynamics that await further study. I will return to this point in the concluding section of this essay.

\subsection{Rumi Authors, Arabic Chronicles}

In the chapter on History/Historiography ( $\mathrm{Ilm}-\mathrm{i} \mathrm{Ta}$ 'rih) in his work on the classification of the sciences, Nev'i Efendi (d. 1599) provides his readers with "the books associated with this [science" (el-Kütübü'l-musannefetü fih): The History of Ibn Kathīr, the History of al-Tabarī, the History of Ibn Athīr al-Jazarī, the History of Ibn al-Jawzī and his Mir'āt al-Zamān, the History of Ibn Khallikān, the History of Ibn Ḥajar [al-'Asqalānī], the History of alȘafadī, the History of Jalāl al-Dīn al-Suyuṭī, Siyar al-ṣaḥāba wa-lzuhhād, Hilyat al-abrār, the History of Hakīm al-Nīsābūriī, the History of al-Baghdādī, Ta'rīkh al-hukamā', Kashf al-ghamm, and Ta'rikh al-umam. It is worth pointing out that all the titles in this list were compiled in Arabic (Prochazka-Eisl and Çelik 2015, 53). This fact is particularly striking, as $\mathrm{Nev}^{\mathrm{i} i}$ Efendi chose to write his work in Turkish and included works written in Persian. In addition, it is quite evident that he relied on chronicles written in Turkish for his survey of the history of the Ottoman dynasty 
(Prochazka-Eisl and Çelik 2015, 72-77). Nev'i Efendi was probably inspired by the work of his earlier colleague, Ahmed Taşköprüzade (d. 1560). In the section devoted to History in his comprehensive work on the classification of the sciences, Taşköprüzade offers a remarkably similar, though much longer, list of works. Among the works Taşköprüzade's lists are The History of Ibn Kathīr, the History of al-Ṭabarī, the History of Ibn al-Athīr alJazarī, the History of Ibn al-Jawzī, Ibn al-Jawzī's Mir'āt al-zamān, the History of Ibn Khallikān, the History of Ibn Hajar and his Anbā' al-ghamr fi abnā' al-'amr and al-Durar al-kāmina fí a yyān almi'a al-thāmina, the History of al-Șafadī, the History of Jalāl alDīn al-Suyutī and his Ṭabaqāt al-nuhāh (his Bughyat al-wu'āh fi țabaqāt al-lughawiyyinn wa-l-nuḥāh), the History of al-Baghdādī, the supplement to al-Baghdādī's History by Ibn al-Najjār, the History and works of Abū Sa'd al-Sam'ānī, the supplement to alSam'ānī's History by al-Dabīthī, the History of al-Dhahabī, Kitāb al-bārī‘ by Ibn Abī Manșūr, and Yatìmat al-dahr by al-Nīsābūrī. At the conclusion of the list, Taşköprüzade briefly states that "the chronicles in Persian are too numerous to be counted," but does not include a similar list of noteworthy Persian and Turkish chronicles (Tāshkubrīzāda [Taşköprüzade] 1968, 1:251-70). ${ }^{6}$ It appears that for Taşköprüzade, much like for $\mathrm{Nev}^{\mathrm{c}} \mathrm{i}$ Efendi, the point of reference was the historiographical tradition in Arabic.

Nothing attests more to Taşköprüzade's historiographical preferences to writing history in Arabic than his own introduction to his biographical dictionaries of the jurists and scholars

\footnotetext{
${ }^{6}$ For an English translation of this section, see Rosenthal (1968, 53035).
} 
who were affiliated with the Ottoman dynasty. In the introduction to this work, he explains why he decided to compile this work:

Since I [learned to] distinguish between right and left, between the straight [path] and trickery, I sought passionately the merits of the 'ulama') and their histories ( $a k h b \bar{a} r$ ), and I was obsessed with memorising their important deeds and their works, until I would accumulate a large [body of knowledge] in my weak memory [so] it would fill the books and notebooks. Historians have recorded the merits of the 'ulama' and the notables according to what has been established through transmission or was confirmed by eyewitnesses, [but] no one has paid attention to the 'ulama' $\bar{a}^{\text {' of }}$ these lands, and [consequently] their names and practices have almost vanished from the tongues of every present [i.e., living person] and [their memory] perished. When the people of excellence and perfection noticed this situation, they asked me to gather all the merits of the 'ulama' in Rum. (Tāshkubrīzāda [Taşköprüzade] 1975, 5)

Note the similarities between the passage from Taşköprüzade's introduction and the comment al-Nahrawāli made to the Grand Vizier. Writing in Arabic, Taşköprüzade claims that only the recording of the histories of the Rumi scholars as part of the Arabic historiographical corpus-a corpus that was compiled elsewhere, beyond the Ottoman lands-can perpetuate their memory.

It appears that the perception of and anxiety about the Arabic historiographical tradition as more eternal than historical writings in Turkish and Persian subsided over the course of the 17th century. For instance, in the universal history he wrote in Arabic, Müneccimbaşı (or Munajjim Bāshī, d. 1702) includes a bibliography of historical works on which he drew. Although he 
organised the list according to the languages in which the works were written, his bibliography represented the historiographical traditions in the three languages: Arabic, Persian, and Turkish. Yet, it seems significant that Müneccimbaşı (Jāmi` al-duwal, 2a) retained the distinction between the traditions. Clearly, he knew that each of these traditions followed different conventions and employed distinctive vocabularies.

Most studies of historical writing in the Ottoman lands have tended to focus on the historiographical production in a specific language. The insightful collection of essays on Ottoman courtly historiography focuses almost exclusively on works written in Ottoman Turkish (Çıpa and Fetvaci 2013). On the other hand, Michael Winter, in his survey of Arabic historiography in the Ottoman Empire, ignores the writings in Persian and Turkish (Winter 2006, 171-90). To be sure, most scholars acknowledge that writings in Turkish include many expressions from Arabic and Persian and that expressions in Arabic frequently feature in Persian texts. But little scholarly attention has been paid to the manner in which the historiographical traditions relate to one another: are there particular expressions or conventions that can be associated (or, at least, more commonly associated) with a certain tradition? Which expressions and conventions were borrowed and, equally important, which were not? And when and why did authors choose to write in a specific historiographical tradition?

These questions draw attention to differences among the various historiographical traditions that coexisted and interacted throughout the Ottoman realms. In a recent study of 15th-century debates among five thinkers writing in Arabic and Persian about 
the nature of historical inquiry, Christopher Markiewicz (2017, 221) argues that

monolingual approaches to Islamic historiography further obscure the full extent of the fifteenth-century discourse on history. The tendency to divide Islamic historiography between its Arabic, Persian, and Ottoman Turkish expressions reinforces an understanding of the historical traditions as separate, linguistically delineated dialectics. Moreover, while considerations of Ottoman historical writing generally acknowledge its relationship to Arabic and especially Persian historiography, the interrelationship between the three remains only superficially acknowledged.

Markiewicz thus concludes that

the wide-ranging interaction between Arabic and Persian historical thought since the tenth century-and Turkish historiography, as well, beginning in the fifteenth century-constituted a fundamental aspect of the development of Islamic historiography as a vibrant cultural tradition until the rise of national historiographies in the late nineteenth and twentieth centuries.

I do not disagree with Markiewicz's general observation, but, in this short essay, I would like to highlight the special semiotic baggage that writing in Arabic carried in the context of a multilingual empire and the dynamics between multiple historiographical traditions. It seems to me that the study of historical writing in the Ottoman lands-and, in fact, across the Islamic(ate) world more broadly-ought to acknowledge the fairly wide range of interactions between these traditions, from the retention of differences to translations and borrowings. In this 
sense, what follows seeks to nuance the idea of a single historiographical project as a singular "vibrant cultural tradition."

Paying attention to these differences can also reveal how members of various learned circles across the Empire employed historiographical traditions and conventions to legitimise Ottoman rule and to enrich the Ottoman repertoire of power. At the same time, studying the manners in which certain expressions were employed may reveal tensions between competing claims and political projects. To illustrate this point, I now turn to examining in some detail the use of the expression "the Ottoman Dawla" (or al-Dawla al-'Uthmāniyya) in the 16th and 17th centuries.

\subsection{Ottoman Devlet/Ottoman Dawla}

In what is perhaps the most systematic study of the meaning of the term dawla during the Mamluk period (1250-1517), Jo Van Steenbergen $(2016,55)$ observes that

[i]n the course of many centuries of Arabic and Islamic history the Arabic noun dawla has appeared as a generic qualifier in many different contexts of rule, with complex meanings that are not always easily rendered in other languages. However, in its semantic essence, as suggested by Arabic lexicographers, dawla is always meant to refer in these contexts of rule to a particular political formation's temporary local monopoly of violence and of access to resources [. . .] But historically the Arabic noun dawla has always also been imbued with the transcendent, religious meaning of a God-given "turn"-the literal translation of the Arabic noun dawla-or term of rule in the monotheist trajectory of human history. In the hearts, minds and ears 
of those who used it, dawla therefore appealed to the idea of a universal empire as much as to that of a territorial state.

The multi-layered nature of the term dawla-a political and authoritative order and a divinely ordained mandate to rule-poses considerable questions when one encounters the use of the possessive adjective attached to it (or the compound noun), as in the case of Dawlat al-Atrāk 'the dawla of the Turks' or al-dawla al'Uthmāniyya in Mamluk Arabic sources. Evidently, Mamluk authors imagined a

trans-regional hierarchy of (West-Asian or even wider) legitimate political leadership, which included Syrian viceroys as well as all kinds of Mongol, post-Mongol and other leaders, and which was topped by the royal persona of the sultan in Cairo. (Steenbergen 2016, 55)

Moreover, this perception of multiple dawlas, each with its own political and institutional orders, was also based on a sense of temporality, hence the succession of several dawlas in Mamluk historiography (Steenbergen 2016, 65).

One could argue that Ottoman authors were not oblivious to the perception of dawla from the Mamluk sources. But Ottoman sources, mostly written in Turkish, tended to focus on the more universal dimensions of dawla or devlet. ${ }^{7}$ For 15 th- and 16th-century Ottoman writers, following Dimitris Kastritsis'

\footnotetext{
${ }^{7}$ The Ottoman authors were drawing on a well-established use of the term dawlat in Persian sources from the Ilkhanid period onward (Allsen 2009, 1-7). I am grateful to Yoni Brack for bringing this piece to my attention and for an illuminating discussion on the use of the term dawlat in the Ilkhanid context.
} 
(2007, 98, 200-3) translation of the term, devlet conveyed a sense of charismatic rule, or, in Hüseyin Yilmaz's (2018, 139, 157) translation, fortune or "auspicious turn to rule." Importantly, while many contenders to the throne may have some degree of devlet, once enthroned, devlet temporarily resided with the ruling sultan. As an early 15th-century source quips with regard to the competition among Ottoman princes during the interregnum, "Although devlet existed in Musa,/The devlet of Mehmed [the future Mehmed I] was truly greater!" (Kastritsis 2007, 219, 226). This is not to say that Ottoman dynasts did not recognise the legitimacy of other Muslim rulers or did not assume that the House of Osman as a whole had a right to rule, but it is important to note that, for the most part, authors writing in Turkish over the course of the 15th through the 17th centuries were quite reluctant to attach a possessive adjective 'Ottoman' to the noun devlet. Instead, in the 16th century, as Y1lmaz $(2018,275)$ has observed, they stressed its eternity.

\subsection{Rumi Authors and Their Use of al-Dawla al- 'Uthmaniyya}

In the second half of the 16th century, several Rumi authors, that is, authors from the core, predominantly Turkish-speaking regions of the Empire, engaged in writing works in Arabic. Being Rumi, it should be emphasised, was not simply a matter of geography. In the context of an expanding empire, it was also a matter of political affiliation with the Ottoman dynasty. These Rumi authors who were writing in Arabic were astutely aware of the con- 
ventions of the Arabic historiographical tradition. In fact, the encounter of what was now the core lands of the Ottoman empire, and of Anatolia more generally, with historical writings in Arabic long predated the Ottoman conquest. Indeed, the inventory of the library of Bayezid II includes historiographical essays and chronicles in Arabic, some of which were even sent directly to members of his close retinue from the Mamluk capital (Markiewicz 2017, 236-40). What is intriguing about the second half of the 16th century is the Rumi authors' experiment with, participation in, and response to the Arabic historiographical tradition.

Perhaps the most extreme example of this engagement is the probably early 17th-century compilation of a text that was falsely attributed to the renowned 13th-century mystic Muhyì alDīn Ibn 'Arabī (d. 1241), titled al-Shajara al-nu'māniyya fì aldawla al-'Uthmāniyya ('the Tree of $\mathrm{Nu}^{\text {'mān }}$ on the Ottoman Rule/Good Fortune'). In this short and popular text, Ibn 'Arabì allegedly foresaw the Ottoman conquest of the Arab lands. As Ahmed Zildzic, who studied in great detail the Shajara and its commentaries, has noted (Zildzic 2012, 85)

[t] he oldest existent copy of al-Shajara comes from the first half of the XVII century, and if we accept that the date is not a later interpolation, we can conclude the text of alShajara as it reached us originated more than a century later than the events it discusses. What is evident, however, is the universal acceptance of the work in the Ottoman cultural and intellectual context.

For our purpose here, the important point is that the late anonymous author used the term al-Dawla al-'Uthmāniyya in the title of the treatise to indicate that it originated in the early 13th 
century in the Arabic-speaking lands. Indeed, one could argue that the invocation of the term was quite antiquarian.

As I have already suggested above, Taşköprüzade was interested in writing an Arabic biographical dictionary that would commemorate the names and deeds of jurists and Sufi masters who were affiliated with the Ottoman dynasty. Clearly, he sought to be part of the Arabic historiographical tradition. Fittingly, the work is replete with references to that tradition and the conventions of the genre of the biographical dictionary. He even decides to call the Ottoman political project al-Dawla al-'Uthmāniyya.

Several decades later, during the reign of Murad III (r. 1574-1595), a third author, Mustafa Cenabi (d. 1590/1591), chose to pen a work in Arabic, a universal history from the creation of the world to the Ottoman dynasty. Cenabi devoted chapters to the various dynasties who ruled the world, from the ancient Persian kings to his patrons, the Ottomans. Throughout, Cenabi (Cenabi Tarihi) selectively employs the term dawla: the Hasanì dawla of Mecca, the Hāshimīi dawla of Medina, the Circassian dawla (the Mamluks), the 'Alawì/Hasanì dawla of Tabaristan and Jurjan, the Samanid dawla, the dawla of Chinggis Khan, the Uzbek dawla, the dawla of the Ak Koyunlu and the Ottoman dawla. Indeed, this list of dawlas seems to reflect the "trans-regional hierarchy of (West-Asian or even wider) legitimate political leadership" (Steenbergen 2016, 55) that one finds in Mamluk sources and the sense that dawla can be divided among rulers and dynasties. 


\subsection{Conclusion}

The macaronic nature of the language that is commonly referred to as 'Ottoman Turkish' is quite well known and frequently mentioned in handbooks for students of the language. Students of 'Ottoman Turkish' are encouraged to study Arabic, Persian, and Modern Turkish/Turkic language and, based on this knowledge, to understand the logic of 'Ottoman Turkish'. This is, of course, an anachronistic perception of languages in general and of 'Ottoman Turkish' in particular, as it assumes fairly well-defined linguistic traditions or languages which are macaronically intertwined. But both Persian and Turkic languages have accumulated over the centuries numerous words that are morphologically Arabic. In many cases, the words retained their 'original' Arabic lexicographical meaning. But this has not always been the case. This linguistic entanglement raises an intriguing question: Where does 'Arabic' end and 'Ottoman Turkish' begin?

This short essay is an attempt to explore these complex dynamics between 'Arabic' and 'Turkish' in the Ottoman lands. My goal is not, to paraphrase Nile Green's $(2019,2)$ comment on Persian in the introduction to the recent volume on the Persianate world, "to promote Arabic [...], but rather to analyze Arabic as a field of sociolinguistic contact, and in doing so recognise the roles of hegemony and competition [...]." Indeed, as Murat Umut Inan $(2019,88)$ argues in his essay on Persian in the Ottoman world in the same volume, the history of Persian-and, one may add, of Arabic - in the Ottoman context is "intertwined with multiple histories of the empire." Much like Persian, Arabic afforded 
Rumi writers a range of possibilities to promote political and intellectual claims, but also engendered anxiety and envy. The manner in which Rumi writers employed the terms al-Dawla al'Uthmāniyya and the anecdote with which I opened this essay capture these possibilities and anxieties.

Furthermore, the tension between devlet and dawla, which draws on the distinction between different linguistic/historiographical traditions, poses a translation challenge: how should one translate al-Dawla al-'Uthmāniyya into, say, English? This translation challenge is what got me interested in exploring the relationship between devlet and dawla in the first place. Moreover, as I have argued elsewhere (Burak 2015, 94-98), in his alShaqā’iq al-nu'māniyya, Taşköprüzade employed Mamluk (and Arabic) historiographical conventions to legitimise and record the history of the Ottoman learned hierarchy and the Sufi masters that were associated with the Ottoman domains. Accordingly, the narrative arc of the Shaqā'iq diverges in terms of its historiographical and, indeed, political assumptions from those of Mamluk biographical dictionaries. Most notably, the Ottoman dynasty is the organising principle of Taşköprüzade's work. Further, when Taşkörüzade's Shaqā’iq was translated by Mehmed Mecdi Efendi (d. 1591) into 'Ottoman Turkish', al-Dawla al-'Uthmāniyya entered 'Ottoman Turkish' historiography. This Turkified expression raises yet another, though related, translation question: how should one translate the 16th-century expression Devlet-i 'Osmaniyye into English? 


\section{References}

Abū Shāma. 1997. 'Abd al-Raḥmān ibn Ismā'īl al-Rawḍatayn fi akhbār al-dawlatayn. Beirut: Mu’assasat al-Risāla.

Allsen, Thomas T. 2009. 'A Note on the Mongol Imperial Ideology'. In The Early Mongol Language, Culture and History: Studies in Honour of Igor de Rachewiltz on the Occasion of his 80th Birthday, edited by Volker Rybatzki et al., 1-8. Bloomington: Indiana University Press.

Blackburn, J. R. 2005. Journey to the Sublime Porte: The Arabic Memoir of a Sharifian Agent's Diplomatic Mission to the Ottoman Imperial Court in the Era of Suleyman the Magnificent. Beirut: Ergon Verlag Würzburg in Kommission.

—. 2012. 'al-Nahrawālī'. In Encyclopaedia of Islam, Second Edition, edited by P. Bearman et al. http://dx.doi.org/10.1163/1573-3912_islam_SIM_5759, consulted online 6 February 2021.

Burak, Guy. 2015. The Second Formation of Islamic Law: The Hanafi School in the Early Modern Ottoman Empire. New York: Cambridge University Press.

2017. 'Between Istanbul and Gujarat: Descriptions of Mecca in the Sixteenth-Century Indian Ocean'. Muqarnas 34: 287-320.

Cenabi, Mustafa. Cenabi Tarihi, Süleymanıe Library, MS Ayasofya 3099.

Cenatar, Mehmet. 2005. 'Mustafa Cenabi'. In Historians of the Ottoman Empire, The University of Chicago: https://ottomanhistorians.uchicago.edu/tr/historian/mustafa-cenabi, consulted online 28 January 2018. 
Çıpa, H. Erdem, and Emine Fetvaci (eds.). 2013. Writing History at the Ottoman Court: Editing the Past, Fashioning the Future. Bloomington: Indiana University Press.

Fleischer, Cornell H. and Kaya Şahin. 2019. 'On the Works of a Historical Nature in the Bayezid II Library Inventory'. In Treasures of Knowledge: An Inventory of the Ottoman Palace Library (1502/3-1503/4), edited by Gülru Necipoğlu, Cemal Kafadar, and Cornell H. Fleischer, 569-96. Leiden: Brill.

Green, Nile. 2019. 'Introduction'. In The Persianate World: The Frontiers of a Eurasian Lingua France, edited by Nile Green, 1-71. Oakland: University of California Press.

Inan, Murat Umut. 2019. 'Imperial Ambitions, Mystical Aspirations: Persian Learning in the Ottoman World.' In The Persianate World: The Frontiers of a Eurasian Lingua France, edited by Nile Green, 75-92. Oakland: University of California Press.

Kafadar, Cemal. 2007. 'A Rome of One's Own: Reflections on Cultural Geography and Identity in the Lands of Rum'. Muqarnas 24: 7-25.

Kaleli, Abdullah. 2014. 'Du'a-name (İnceleme-Çeviri Yazılı Metin-Özel Adlar Dizini-Tıpkıbasım'. MA thesis, Adiyaman Üniversitesi Sosyal Bilimler Enstitüsü.

Kastritsis, Dimitris J. 2007. The Sons of Bayezid: Empire Building and Representation in the Ottoman Civil War of 14021413. Leiden: Brill.

Köker, Ahmet Hulusi (ed.). 1999. Kinalizade Ali Efendi (15101572). Kayseri: Erciyes Üniversitesi Matbaası. 
Mantran, R. 2012. "Alī Pasha Semiz'. In Encyclopaedia of Islam, Second Edition, edited by P. Bearman et al. http://dx.doi.org/10.1163/1573-3912_islam_SIM_0537, consulted online on 06 February 2021.

Markiewicz, Christopher. 2017. 'History as Science: The Fifteenth-Century Debate in Arabic and Persian'. Journal of Early Modern History 21: 216-40.

Mengüç, Murat Cem. 2013. 'Histories of Bayezid I, Historians of Bayezid II: Rethinking Late Fifteenth-century Ottoman Historiography'. Bulletin of SOAS 76: 373-89.

Müneccimbaşı. Jāmi` al-duwal. Süleymaniye Library MS Esad Efendi 1201, 2a.

al-Nahrawālī, Muḥammad b. Aḥmad b. Muḥammad. 2004. Kitāb al-I lām bi-a lām Bayt Allāh al-ḥarām. Cairo: Maktabat alThaqāfa al-Dīniyya.

Pfeifer, Helen. 2015. 'Encounters After the Conquest: Scholarly Gatherings in 16th-Century Ottoman Damascus'. International Journal of Middle East Studies 47: 219-39.

Prochazka-Eisl, Gisela, et al., 2015. Texts on Popular Learning in Early Modern Ottoman Times, volume II: 'The Yield of the Disciplines and the Merits of the Texts': Nev'i Efendi's Encyclopedia Netayic el-Fünun. Cambridge, MA: The Department of Near Eastern Languages and Civilizations, Harvard University.

Rosenthal, Franz. 1968. A History of Muslim Historiography. Leiden: Brill. 
Steenbergen, Jo Van. 2016. 'Appearances of Dawla and Political Order in Late Medieval Syro-Egypt: The State, Social Theory, and the Political History of the Cairo Sultanate (Thirteenth-Sixteenth Centuries)'. In History and Society During the Mamluk Period (1250-1517): Studies of the Annemarie Schimmel Institute for Advanced Study II, edited by Stephen Conermann, 51-85. Bonn: Bonn University Press.

Tāshkubrīzāda (Taşköprüzade), Aḥmad ibn Mușṭafá. 1968. Miftāḥ al-sa'āda wa-miṣbāḥ al-siyāda fì maw ḍū'ăt al-'ulūm. Cairo: Dār al-Kutub al-Hadītha.

—_. 1975. ibn Muștafá al-Shaqā̄iq al-nu'māniyya fì 'ulamā’’ aldawla al-'Uthmāniyya. Beirut: Dār al-Kitāb al-`Arabī.

Tezcan, Baki. 1996. 'The Definition of Sultanic Legitimacy in the Sixteenth-Century Ottoman Empire: The Ahlak-i Ala'i of Kinalizade Ali Çelebi (1510-1572)'. MA thesis, Princeton University.

Winter, Michael. 2016. 'Historiography in Arabic during the Ottoman Period'. In Arabic Literature in the Post-Classical Period, edited by Roger Allen and D. S. Richards, 171-88. Cambridge: Cambridge University Press.

Y1ld1z, Sara Nur. 2012. 'Ottoman Historical Writing in Persian, 1400-1600'. In Persian Historiography, edited by Charles Melville, 436-502. New York: I. B. Tauris.

Y1lmaz, Hüseyin. 2018. Caliphate Redefined: The Mystical Turn in Ottoman Political Thought. Princeton, NJ: Princeton University Press. 
Zildzic, Ahmed. 2012. 'Friend and Foe: The Early Ottoman Reception of Ibn 'Arabi'. PhD dissertation, University of California, Berkeley. 



\title{
5. ARABIC GRAMMAR BOOKS IN OTTOMAN ISTANBUL: THE SOUTH ASIAN CONNECTION ${ }^{1}$
}

\author{
Christopher D. Bahl
}

The transregional transmission of Arabic grammar books from South Asia to the Ottoman Empire contributed significantly to the scholarly curriculum of Ottoman Istanbul and beyond over the 16th and 17th centuries. Based on a study of several manuscripts of al-Muḥammad al-Damāmīnī's (d. 827/1424) and Shihāb al-Dīn al-Dawlatābādī's (d. 848/1445) commentaries (shurūh, sg. sharh), this article will argue that commentaries from South Asia on Arabic grammar treatises from earlier periods circulated widely among learned groups of Ottoman Istanbul. Thereby, they formed a crucial part of the scholarly engagement with the Arabic philological tradition and its broader cultural idiom in the Ottoman Empire. A focus on the variety of manuscripts, their marginalia and paratexts can shed light on cultural

\footnotetext{
${ }^{1}$ I am grateful to Prof. Konrad Hirschler for valuable comments and to several audiences at conferences in Ghent, Berlin, and Oxford for their feedback on earlier drafts of this paper. I thank Alice Williams for her suggestions.
} 
practices in the circulation and reading of philological texts that emerged over the course of the 16th and 17th centuries.

A burgeoning field of scholarship on the early modern Middle East and South Asia has diversified its sources and approaches to the study of elite formation, scribal cultures and text circulation over the last years. Francis Robinson and Maria Szuppe expounded various scholarly connections and a shared canon of Islamicate works across the Ottoman, Safavid and Mughal dispensations (Robinson 1997; Szuppe 2004). Sanjay Subrahmanyam's 'connected histories' across Eurasia interrelated synchronous historical processes on commensurable levels of inquiry to study the workings of cultural encounters (Subrahmanyam 1997 and 2012). In particular, a focus on scribal cultures and traditions of $a d a b$ and $a k h l a \bar{q}$ informed the study of Indo-Persian forms of governance and bureaucracies, mainly across the Mughal world, but with implicitly strong connections across Western Asia (Alam 2004; Kinra 2015). Yet, while there is a general consensus that early modern entanglements facilitated forms of exchange among imperial elites and other sociabilities such as Sufi networks (Choudhury 2016), there is still room for further explorations regarding the empirical and material foundations of such cultural exchanges.

While Persian was central to these trans-imperial connections, Arabic has been considered as a major complementary idiom among mobile imperial and scholarly elites, but for different reasons. On the one hand, Arabic was a significant communicative medium among mobile learned groups between the regions of Gujarat and the Deccan with Yemen and the Hijaz (Robinson 
1997; Ho 2006) but also across the wider Indian Ocean region (Ricci 2011). On the other hand, Arabic served in inquiries relating to a wider Islamicate canon across the disciplines of Quranic exegesis (tafsir) and Islamic law (fiqh) (Ho 2006). Still, it could serve a variety of further social and cultural purposes. Recent studies by Rajeev Kinra on the Mughal bureaucratic elite have pointed out Arabic's integral part in the educational curriculum of a Mughal civil servant responsible for running the day-to-day imperial administrative business (Kinra 2010, 552). Similarly, Khaled El-Rouayheb's recent work on Islamic intellectual currents in the Ottoman Empire made implicit the central place of Arabic philology in the linguistic schooling of scholarly elites (ElRouayheb 2015, 97-105).

Thus, Arabic philology was a requisite for the cultural refinement of the learned elites across early modern Islamicate cultures. Yet, while scholarship has explored the multifaceted terrain of Arabic philology over earlier periods, especially the disciplines of grammar ('ilm al-nahw), rhetoric ('ilm al-balägha) and lexicography ('ilm al-lugha), research into later commentarial traditions is only in its infancy (Simon 1993; Gully 1995; Bauer 2005). At the same time, these studies mainly focus on the Arabic scholarship from the medieval central Arab lands and Persia, but often do not acknowledge contributions from learned centres across other regions.

As I will argue in the following, scholarly contributions from South Asia became more important from the 15th century onwards, when intellectual conversations and debates in Arabic philology extended further to the East. Scholars across the South 
Asian subcontinent composed treatises and commentaries on Arabic syntax, morphology and rhetoric which circulated widely across learned groups of the Ottoman worlds further west by the 16th and 17th centuries (Ahmad 1946). A survey of the manuscript collections of the Süleymaniye Library in Istanbul discloses a large number of copied commentaries in the field of rhetoric by well-known figures such as al-Siyalkūtī, a courtier of the Mughal Emperor Shāh Jahān (Ed. 2018). However, there are also commentaries in the field of grammar from less-prominent figures, such as Muḥammad al-Damāmīnī (d. 827/1424) and Shihāb alDīn al-Dawlatābādī (d. 848/1445). And these are spread across a wide range of the individual collections of the Süleymaniye (Hitzel 1999).

\subsection{Writing Nahw in 15th-century South Asia}

Al-Damāmīnī's and al-Dawlatābādī's contributions to Arabic grammar have to be situated within the wider processes of decentralisation that shaped the political landscape of 15th century South Asia. The declining Delhi sultanate was superseded by a regionalised configuration of courts from Gujarat, Malwa in the West to Jawnpur and Bengal in the East, and the Bahmani kingdom in the Deccan (Schimmel 1980, 36-74; Asher and Talbot $2006,85)$. These new political dispensations began to compete for service elites and scholars and could offer lavish patronage to those seeking to live their lives as migrant scholars. Muhammad al-Damāmīnī (763-827/1362-1424) was born in Alexandria in Egypt and had passed through various educational stages in Mamlūk Egypt and Syria, teaching at the al-Azhar mosque among 
other learned sociabilities (al-Sakhāwī 1934-1937, VII:184-87). His change of career into the weaving business was unsuccessful and after the pilgrimage to Mecca he embarked on a career as a mobile scholar which first brought him to Zabìd in Yemen, but then even further across the Western Indian Ocean to Cambay and Nahrwāla (Patan) in Gujarat (see prefaces in MS Ragip Pasa 1326 and MS Carullah 1941). He received patronage from the court of Ahmad Muzaffar Shāh and composed, amongst other works, three grammar commentaries. The first work, written after his arrival in the western port city of Kanbāyat (Cambay) in Gujarat during the years 820-821/1417-1418, is the Ta liq alfarā'id 'alā tashìl al-fawā'id 'Explanation of the precious pearls on the facilitation of benefits', a commentary on Ibn Mālik's (672/1274) Tashìl al-fawā’id wa-takmìl al-maqāṣid 'The facilitation of benefits and the completion of objectives' (see prefaces in MS Ragip Pasa 1326 and MS Carullah 1941; Fleisch 2017a; 2017b). The second work, composed while he resided in the famous scholarly centre of Nahrwāla in Gujarat in 824/1421, is entitled Tuhfat al-gharīb 'alā l-kalām mughnì al-labīb 'an kutub al$a^{`} \bar{a} r i \bar{b}$ 'Gift of the extraordinary concerning the speech of sufficient understanding on the books of declinations', a commentary on Ibn Hishām's (d. 760/1360) treatise on syntax, al-Mughni allabib (see preface and colophon of MS Bijapur 7; Fleisch 2017b). He then continued his vagrant life and travelled on to the Deccan. A third work, written while on his way from Gujarat to the city of Ahsānābād (Gulbarga) in the Bahmanī realm of the Deccan during the years 825-826/1422-1423, is entitled al-Manhal alșafi fi sharh al-wäfi 'The pure watering place in the explanation of 
the perfect', again a commentary, in this case on al-Balkhï's (d. 8th/14th c.) grammatical work al-Wāfi (see preface in MS Nahw 108). This was presented to the sultan Ahmad Shāh Bahmanī and seems to have been his last scholarly composition before he died in 1424.

Al-Damāmīnī's contemporary Shihāb al-Dīn Aḥmad b. Shams al-Dīn al-Hindī al-Dawlatābādī (d. 848/1445) had a different professional trajectory, but he similarly benefitted from the increasing availability of courtly patronage during the 15th century. Al-Dawlatābādī was born in Dawlatābād in the Deccan, studied in Delhi and after Timur Tamerlane's invasion in 1398 he left and became attached to the court of Sulțān Ibrāhīm Sharqī (804-844/1400-1440) in Jawnpūr as prime judge (qāḍi al-qudāt) and scholar (Nizami 2018). And there he joined a larger group of learned men who turned the court of Jawnpur into a flourishing centre of learning during the 15th century (Würsch 2018). He soon received the title Malik al-'Ulamā') (Nizami 2018). Among the works he composed during his courtly tenure are the commentary Sharh al-Hindi on the famous treatise al-Kafiya by Ibn alHājib (d. 646/1249) as well as the work al-Irshād, a treatment of Arabic syntax (Nizami 2018).

With their texts in the field of nahw both scholars primarily provided crucial commentaries for the refinement of Arabic. The shurūh were written with a South Asian audience in mind that engaged with the Arabic cultural idiom on a different canonical textual background in comparison to what for example al- 
Damāmīnī had been accustomed to in Mamlūk Egypt ${ }^{2}$. Ultimately, such works served to develop skills in the exegesis of Islamic canonical works. And this intellectual purpose had also shaped the textual fabric of these commentaries. Grammar works were thick intertextual re-fabrications of Islamicate canonical texts. Excerpts of Islamic canonical works, specimen of poetry and by the early modern period a diverse commentarial layer had turned Arabic grammar books not only into foundational readings in the acquisition of Arabic language skills, but also substantiated them as digests of Islamicate cultural traditions (Gully 1995).

While these commentaries thereby contributed to the larger discourse and perpetuation of Islamicate textual traditions, the extent of the contribution of al-Damāmīnī's and al-Dawlatābādī's commentaries to different regional and local learned sociabilities can only be gauged by tracing the transmission of their texts as manuscript copies. Marginalia and paratextual elements on manuscripts offer a window into the world of reading practices, the conditions of the perception of texts among audiences and the

\footnotetext{
${ }^{2}$ This becomes especially clear when comparing two of al-Damāminnī's commentaries on the same treatise, one written in Egypt and the other composed in Gujarat. The intertextual variety and reference to scholarly authorities differs considerably, a venue of research that I elaborated on in Bahl (2018).
} 
forms of circulation among scholarly networks (Görke/Hirschler 2011)..$^{3}$

\subsection{Manuscript Circulation in Ottoman Istanbul}

In comparison to al-Damāmīnī, who was an established scholar before he had left Egypt for India, knowledge about al-Dawlatābādī's scholarly background and oeuvre must have slowly spread across scholarly networks from South Asia to Ottoman Istanbul. A survey of his commentaries on nahw in the Süleymaniye Library in Istanbul reveals 30 manuscripts of his Sharh Hindi on the treatise al-Käfiya for the 9th-11th (roughly 15th-17th) centuries, and only one version of the Irshäd, his summary on Arabic syntax. The majority of these versions can be dated to the 16th and 17th centuries. Even if other works circulated in larger quantities, the numbers for the Sharh Hindi point to a considerable circulation of al-Dawlatābādī's texts in Istanbul and beyond. And the general reference to his commentary in various short-hands such as Sharh Hindī, Kitāb Hindī, and simply Hindī suggest that his work had become common parlance in the early modern Ottoman Empire.

Due to fragmentary spatial data, it is often difficult to clearly trace a direct transfer of manuscripts from South Asia to Ottoman Istanbul. The inscription of a specific paratext can serve as a very tentative indicator for an initial circulation of a text in South Asia. Across South Asia the phrase yā kabikaj (the term

${ }^{3}$ The terms and concepts paratexts, hypertexts, intertextualities and other forms of transtextualities throughout this article are taken from Genette (1993; 2001). 
kabikaj refers to wild parsley and 'king of the cockroaches') was often written on the fly-leaf of a book in the belief that this formula would save the manuscript from cockroaches (Steingass 1977) ${ }^{4}$. Adam Gacek (1986) further referred to the regional varieties in the use of such talismanic paratexts locating the use of $y \bar{a}$ kabikaj in the subcontinent. Among the collections in Istanbul, four manuscripts of al-Dawlatābādī's commentary come with this inscription on the fly-leaves and one of them even contains a separate inscription on the folios with the table of contents (see the fly-leaves of MSs Aya Sofya 4501, Darulmesnevi 1504, Laleli 3416, Yusuf Aga 347). However, even if the phrase $y \bar{a} ~ k a b i k a j$ developed in this form in South Asia, the practice of its inscription on manuscripts could have (and probably did) circulated as far as the Ottoman Empire among mobile learned groups. Thus, the use of the phrase $y \bar{a}$ kabikaj can only situate the respective manuscript within a wider circulation of cultural practices and scribal traditions that extended as far as the subcontinent. A more precise assessment of the geographical spread of the use of $y \bar{a}$ kabikaj awaits the study of larger surveys of manuscripts.

Additionally, since references to places were not always provided in the colophons, the exact origin of most of the manuscripts cannot be traced in detail. Yet, some versions demonstrate copying efforts across the Ottoman Empire making manifest a proliferation of the Sharh Hindì among its learned audiences. In two versions the respective scribes located their transcriptions in the city of Constantinople (qustantinizya) (see the colophons in

\footnotetext{
${ }^{4}$ I am grateful to Olly Akkerman for pointing this out to me.
} 
MS Esad Efendi 3082 and MS Sehid Ali Pasa 2453). Still, manuscripts also hailed from other regions of the Empire. MS Carullah 1931 of the Sharh Hindi was copied by a certain Muhammad b. Ahmmad b. Yūsuf in 966/1559 in Kefe (also Kaffa), a city on the south-eastern coast of Crimea, and since the reign of Bayezid II (886-918/1481-1512) a sanjak (administrative subdivision of a province) of the Ottoman Empire (Orhunlu 2018). These examples indicate multiple local demands and interests for al-Dawlatābādī's commentary.

Al-Dawlatābādī's text circulated across different scholarly sociabilities in the early modern period and thereby had a crucial share in the learned encounters across the field of Arabic philology. Paratextual profiles on several of his manuscripts demonstrate the minutiae of multiple interpersonal transmissions of the commentary and thereby a high velocity of the text. MS Lala Ismail 635 is a transcription of the Sharh Hindi with the appended hawāshì 'marginalia' of a certain Ibn al-Qal'ī on al-Dawlatābādī's commentary (MS Lala Ismail 635, fol. 171r). After the transcription of both texts by different scribes, the manuscript was first in the possession of a certain Aḥmad b. Abī [...] al-Maḥāsīnī in $1060 / 1650$ and then came into the possession of a certain 'Abd al-Karīm b. Muhammad b. [...] al-Ḥusaynī in 1073/1662 (see MS Lala Ismail 635, fol. 1r). Similarly, another version of the Kitāb Hindi, which was finished in 1028/1619 with a yā kabikaj note, was transmitted (naqala) and owned (șăhabahu) by at least three different people and annotated extensively in this process (MS Laleli 3416, fol. 1r). Al-Dawlatābādī had arrived in the scholarly circles of the Ottoman world. 
Similar paratextual profiles of extensive circulation mark al-Damāmīnī's commentaries, in principle his Tashìl al-fawā'id and the Sharh al-Mughnī or Tuhfat al-gharïb on Ibn Hishām's work of grammar, which, given the numbers of 19 and 35 manuscript versions respectively, circulated more prominently than the Manhal al-șâfi, with only four copies. Most importantly, the circulation of his commentaries was subject to larger changes in the paratextual anatomy of Arabic manuscripts. These can highlight the high degree of incorporation of these commentaries into learned sociabilities of Ottoman Istanbul and beyond.

\subsection{The Emergence of the Fihrist}

Manuscripts in Istanbul of both al-Damāmīnī's and al-Dawlatābādī's commentaries show that by the late 16th and 17th centuries the fihrist (table of contents) emerged as a new paratextual element. The term fihrist comes with a variety of forms and meanings stretched out over a considerable period. Here, I want to distinguish between two types of fihrists, the internal and the external. The internal fihrist refers to the authorial table of contents and constitutes an intertextual feature that often appears at the end of the muqaddima 'introduction' or 'preface' to a work. Internal fihrists form crucial textual elements of transition in an introduction after outlining authorial intention, reason, method and purpose of a work, framed in religious formulae and a localisation in a scholarly genealogy. They offer a 'road map' for the reader, locking the successive evolution of ideas of the work into a set of succinct terms or phrases. Thereby they precondition the 
reading experience by previewing how the larger argument is going to unfold successively. In general, the internal fihrist sprang from the pen of the authors, although the layout in manuscripts could be changed later on by the respective scribes.

In contrast to the internal fihrist, I want to focus on the use of the external fihrist in manuscripts of al-Dawlatābādī's and alDamāmīnī's grammar commentaries, meaning a table of contents that was added subsequently by a reader or scribe. While the different forms of authorial internal fihrists indicate potential perusals of a text, manuscript notes in the form of paratexts, marginalia and other reading statements partially document the actual textual engagement of a reader with a text. ${ }^{5}$ They register time and place, when and where a reader intervened or engaged with the text. Needless to say, this does not provide a full account of a reader's intellectual encounters with an oeuvre. Nevertheless, these manuscript notes can indicate changing cultural engagements through their own emergence or alteration over time. Most importantly, the focus on the intertextuality of matn and paratexts provides a perspective that goes beyond the interpretative exercise of a text. It encompasses its appropriation by a reader and thereby the historical significances it had in its perusal at a particular point in time. This means that texts could be appropriated in various ways, which highlights changing cultural practices among communities. ${ }^{6}$

\footnotetext{
${ }^{5}$ A strong argument for tracing such textual engagements in a different context was made in Krimsti (2019, 202-44).

${ }^{6}$ For a more detailed discussion of the fihrist, see Bahl (2018, chapter 4).
} 
For the current purpose, I argue that the emergence of external fihrists during the late 16th and early 17th centuries on manuscripts of al-Damāmīnī's and al-Dawlatābādī's texts underscore their incorporation into scholarly curricula in Ottoman Istanbul. Readers introduced this device to render the texts more accessible. Here, I refer to the external fihrist that does not spring from the pen of the author but was added by a reader at a later stage. I base this argument on an extensive survey of alDamāmīnī's texts and their 58 manuscripts, as well as on 30 manuscripts of al-Dawlatābādī 's text. Such a survey reveals a period of relative absence, relative because there might have been individual cases where such a fihrist was added to the manuscript but did not survive because it would have been located among the more vulnerable fly-leaves, which could have easily been torn away. Still, with the absence of 'tables of contents' for the 15th century, and their appearance during the late 16th and throughout the 17th century, there is a diachronic argument to be made. And although 16th and 17th century copies are empirically based on earlier 15th century transcriptions, they do not feature fihrists from the 15th century. As far as my research has shown, only late 16th and 17th century copies come with fihrists. Their appearance throughout the 17 th century indicates a change over time in these Arabic manuscript cultures.

The more common appearance of external fihrists suggests a historical trend that took off during the early modern period in the wider field of Arabic philology. Four of the 30 manuscripts of al-Dawlatābādī's Sharḥ Hindī survive with a fihrist. Similarly, 
al-Damāmīnī's texts, as they survive on manuscripts in the Süleymaniye in Istanbul, show that the process of fihristisation was not an all-encompassing phenomenon. Altogether 35 transcriptions of either al-Damāmīnī's hindì or yamanì commentary on Ibn Hishām's Mughni al-labīb survive among the Süleymaniye collections. Only one transcription of the hindi commentary, the Tuhfat al-gharib, comes with a fihrist, and this version was copied in 1092/1681 (MS Carullah 1941). Of the four transcriptions of the al-Manhal al-șāfi in Istanbul again only one version has a fihrist, however not dated (MS Haci Selim Aga 1170-001, fol. 1v-2r). Yet, of the 19 copies of the Ta'liq al-farā'id in Istanbul, eight versions entail a fihrist and these versions date to the second half of the 16th and the 17th century (see MS Hekimoglu 888, MS Murad Molla 1675, MS Murad Molla 1676, MS Murad Molla 1677, MS Sehid Ali Pasha 2413, MS Sehid Ali Pasha 2414, MS Laleli 3176, MS Fatih 4909). Two of these versions can be pinned down to a circulation within Istanbul and from Mecca to Istanbul, and thus the wider Ottoman world of the mid-16th century (MS Muradmolla 1675, fol. 248r; MS Hekimoglu 888, fol. 445r).

Scribes and readers added external fihrists to the fly-leaves of a manuscript version. Three manuscripts of al-Dawlatābādī's Sharh Hindī come with a fihrist (MS Darulmesnevi 504, MS Servili 306, MS Yazmabagislar 342). All three are decorated in different ways. MS Darulmesnevi 504 was copied in 1027/1618. It simply consists of an enumeration of terms and sections of the treatise and its commentary, not in the form of a list, but spread out across the two pages together with corresponding folio numbers. MS Servili 306 is not dateable. Here, the fihrist contains a similar 
set of terms, but their arrangement is ordered and framed through a grid pattern, each field containing one term and the respective folio number across three pages. MS Yazmabagislar 342 , copied in $978 / 1571$, contains a fihrist that only stretches across one half-folio (probably incomplete).

Style and execution suggest several characteristics and functions of these fihrists. Firstly, their location on the fly-leaves before the title-page marks the process of creating the fihrist as separate from the transcription of the matn (main text). Readers or scribes most probably added it later after the completion of the manuscript copy. Secondly, this is further corroborated with the addition of folio numbers. Folio numbers locate the respective grammatical phenomena in the manuscript. Thus, the foliation broke up the text and made it more accessible. Significantly, this also enhanced the readability of the text, since readers could now browse through the fihrist to look up a specific grammatical term or phenomenon which they wanted to study. Thirdly, these terms or phenomena were formalised or standardised in all three manuscript copies. The fihrist functioned like an index that helped a reader navigate the text.

Thus, individual readers began to engage with these texts by creating a fihrist for individual manuscript versions. I argue that readers introduced this device to render the texts more accessible, which would serve them in their study pursuits. The overall location among the fly-leaves defined the paratextual characteristics of the external fihrist as a meaningful written elaboration of a hypertextual appropriation of a text. In general, they 
functioned as practical guides and provided a condensed overview of a work's contents. Fihrists in manuscripts of alDamāmīnī's texts worked in a similar way. They were added to the manuscript at a later stage and appear before the title-page and the introduction to the text. Chapters, sections, important terms and phenomena were often referred to with a particular folio number. In one of the Istanbul versions of the Tuhfat algharīb the fihrist ma $\bar{a}$ l l-kitāb 'index of what is in the book' goes over one and a half folios before the start of the matn's foliation and was marked as completed with the symbol tamma at the end (MS Carullah 1941, fly-leaves). Chapter names were written in red and section titles in black. They were specified with a folio number and corresponded with their counterparts in the matn in red ink. In other cases, fihrist, matn and marginalia seem to be written in the same hand, yet the fihrist still was a final addition, because the foliation of the work conformed with the numbers given in the table of contents (MS Carullah 1941, fly-leaves). In contrast to this, a version of the Manhal al-șâfi entitled fihrist $h \bar{a} d h \bar{a}$ al-kitāb 'index of this book' is produced without foliation (MS Haci Selim Aga 1170-001, fol. 1v-2r). The fihrist offers only a bullet-point summary of grammatical terms and phenomena covered in this commentary.

Changing paratextual profiles in manuscripts of alDamāmīnī's and al-Dawlatābādī's texts document changing textual practices of scribes and readers in this period. They emphasise the high degree to which al-Damāmīnī's and al-Dawlatābādī's texts had become a part of scholarly engagements with Arabic grammar in Ottoman Istanbul and beyond. Thus, both examples 
showcase empirically substantiated transregional connections between early modern South Asia and the Ottoman Empire and how such forms of text transmission were shaped by readers and their needs in the field of Islamicate learned pursuits.

\section{References}

\section{Arabic Manuscripts}

Al-Damāmīnī, M. Ta lìq al-farā'id 'alā tashìl al-fawā'id. MS Ragip Pasa 1326. Süleymaniye Library, Istanbul.

—. Ta lìq al-farā'id 'alā tashìl al-fawā’id. MS Hekimoglu 888. Süleymaniye Library, Istanbul.

—. Ta lìq al-farā’id 'alā tashìl al-fawā’id. MS Murad Molla 1675. Süleymaniye Library, Istanbul.

—. Ta lìq al-farā’id 'alā tashìl al-fawā’id. MS Murad Molla 1676. Süleymaniye Library, Istanbul.

—. Ta lìq al-farā'id 'alā tashìl al-fawā’id. MS Murad Molla 1677. Süleymaniye Library, Istanbul.

—. Ta'lìq al-farā’id 'alā tashïl al-fawā’id. MS Sehid Ali Pasha 2413. Süleymaniye Library, Istanbul.

—_. Ta'lìq al-farā’id 'alā tashïl al-fawā'id. MS Sehid Ali Pasha 2414. Süleymaniye Library, Istanbul.

—. Ta'lìq al-farā'id 'alā tashìl al-fawā'id. MS Laleli 3176. Süleymaniye Library, Istanbul.

—. Ta Tìq al-farā’id 'alā tashil al-fawā'id. MS Fatih 4909. Süleymaniye Library, Istanbul.

_. Tuhfat al-gharīb 'alā l-kalām mughnì al-labīb 'an kutub al$a^{\complement} a \bar{r} i \bar{b}$. MS Carullah 1941, Süleymaniye, Istanbul. 
—_. Tuhfat al-gharìb fi l-kalām 'alā mughnī al-labïb. MS IO Bijapur 7, British Library, London.

__ al-Manhal al-șafiy fi sharh al-wāfìy. MS Haci Selim Aga 1170-001. Süleymaniye Library, Istanbul.

__. al-Manhal al-șafì fi sharh al-wāfiy. MS Sehid Ali Pasa 2535. Süleymaniye Library, Istanbul.

—_. al-Manhal al-șafiy fi sharh al-wäfiy. MS Nahw 108. Salar Jung Museum Library, Hyderabad.

Al-Dawlatābādī, Shihāb al-Dīn. Al-Irshād. MS Husrev Pasa 663. Süleymaniye Library, Istanbul.

—_. Sharḥ al-Hindì 'alā l-Kāfiya. MS Aya Sofya 4501. Süleymaniye Library, Istanbul.

—_. Sharḥ al-Hindī 'alā l-Kāfiya. MS Darulmesnevi 504. Süleymaniye Library, Istanbul.

—_. Sharḥ al-Hindī 'alā l-Kāfiya. MS Esad Efendi 3082. Süleymaniye Library, Istanbul.

—_. Sharḥ al-Hindī 'alā l-Kāfiya. MS Hamidiye 612. Süleymaniye Library, Istanbul.

—_. Sharh al-Hindì 'alā l-Kāfiya. MS Lala Ismail 635. Süleymaniye Library, Istanbul.

—_. Sharh al-Hindī 'alā l-Kāfiya. MS Laleli 3416. Süleymaniye Library, Istanbul.

—_. Sharh al-Hindī 'alā l-Kāfiya. MS Sehid Ali Pasa 2453. Süleymaniye Library, Istanbul.

—_. Sharh al-Hindì 'alā l-Kāfiya. MS MS Servili 306. Süleymaniye Library, Istanbul.

—_. Sharḥ al-Hindì 'alā l-Kāfiya. MS Yazmabagislar 342. Süleymaniye Library, Istanbul. 
—. Sharh al-Hindì 'alā l-Kāfiya. Yusuf Aga 347. Süleymaniye Library, Istanbul.

\section{Secondary Literature}

Ahmad, M. G. Z. 1946. The Contribution of Indo-Pakistan to Arabic Literature. From Ancient Times to 1857. Lahore: Sh. Muhammad Ashraf.

Alam, Muzaffar. 2004. The languages of political Islam. India, 1200-1800. Chicago: University of Chicago Press.

Asher, Catherine B., and Cynthia Talbot. 2006. India before Europe. New York: Cambridge University Press.

Bahl, Christopher. 2018. 'Histories of Circulation: Sharing Arabic manuscripts across the Western Indian Ocean, 1400-1700'. PhD dissertation, SOAS, University of London.

Bauer, Thomas. 2005. 'Rhetorik: Arabische Kultur'. In Rhetorik: Begriff - Geschichte - Internationalität, edited by Gert Ueding, 283-300. Tübingen: Niemeyer (= Gert Ueding [ed.]. 2007. Historisches Wörterbuch der Rhetorik 8:111-37. Tübingen: Niemeyer).

Choudhury, Rishad. 2016. 'The Hajj and the Hindi: The Ascent of the Indian Sufi Lodge in the Ottoman Empire". Modern Asian Studies 50/6, 1888-931.

Eds. 2018. 'al-Siyālkūtī'. In Encyclopaedia of Islam, Second Edition, edited by P. Bearman, Th. Bianquis, C. E. Bosworth, E. van Donzel, W. P. Heinrichs. http://dx.doi.org/10.1163/15733912_islam_SIM_7082, consulted online on 30 January 2018. 
El-Rouayheb, Khaled. 2015. Islamic Intellectual History in the Seventeenth Century: Scholarly Currents in the Ottoman Empire and the Maghreb. New York: Cambridge University Press.

Fleisch, H. 2017a. 'Ibn Mālik'. In Encyclopaedia of Islam, Second Edition, edited by P. Bearman, Th. Bianquis, C. E. Bosworth, E. van Donzel, W. P. Heinrichs. http://dx.doi.org/10.1163/1573-3912_islam_COM_0336, consulted online on 21 February 2017.

. 2017b. 'Ibn Hishām'. In Encyclopaedia of Islam, Second Edition, edited by P. Bearman, Th. Bianquis, C. E. Bosworth, E. van Donzel, W. P. Heinrichs. http://dx.doi.org/10.1163/1573-3912_islam_COM_0326, consulted online on 21 February 2017.

Gacek, Adam. 1986. 'The Use of kabikaj in Arabic Manuscripts'. Manuscripts of the Middle East 1: 49-53.

Genette, Gerard. 1993. Palimpseste: Die Literatur auf zweiter Stufe. Translated by W. Bayer and D. Honig. Frankfurt: Suhrkamp.

—_. 2001. Paratexte: Das Buch vom Beiwerk des Buches. Frankfurt: Suhrkamp.

Görke, Andreas, and Konrad Hirschler. 2011. 'Introduction: Manuscript Notes as Documentary Sources'. In Manuscript Notes as Documentary Sources, edited by Andreas Görke and Konrad Hirschler, 9-20. Beiruter Texte und Studien 129. Würzburg: Ergon-Verlag.

Gully, Adrian. 1995. Grammar and semantics in Medieval Arabic: A study of Ibn-Hisham's 'Mughni l'labib'. Richmond (Surrey): Curzon Press. 
Hitzel, Frédéric 1999. 'Manuscrits, livres et culture livresque à Istanbul'. In Livres et lecture dans le monde ottoman, thème sous la responsabilité de Frédéric Hitzel, 19-38. Revue des mondes musulmans et de la Méditerranée 87-88.

Ho, Engseng. 2006. The Graves of Tarim: Genealogy and mobility across the Indian Ocean. Berkeley: University of California Press.

Kinra, Rajeev. 2015. Writing self, Writing Empire: Chandar Bhan Brahman and the Cultural World of the Indo-Persian State Secretary. Oakland: University of California Press.

. 2010. 'Master and Munshi: A Brahman Secretary's Guide to Mughal Governance'. Indian Economic and Social History Review 47/4: 527-61.

Krimsti, Feras. 2019 ‘Arsāniyūs Shukrī al-Hakīm’s Account of His Journey to France, the Iberian Peninsula, and Italy (17481757) from Travel Journal to Edition'. Philological Encounters 4: 202-44.

Nizami, K. A. 2018. 'al-Dawlatābādī'. In Encyclopaedia of Islam, Second Edition, edited by P. Bearman, Th. Bianquis, C. E. Bosworth, E. van Donzel, W. P. Heinrichs. http://dx.doi.org/10.1163/1573-3912_islam_SIM_1751, consulted online on 31 January 2018.

Orhonlu, Cengiz. 2018. 'Kefe'. In Encyclopaedia of Islam, Second Edition, edited by P. Bearman, Th. Bianquis, C. E. Bosworth, E. van Donzel, W. P. Heinrichs. http://dx.doi.org/10.1163/1573-3912_islam_SIM_4096, consulted online on 26 January 2018. 
Ricci, Ronit. 2011. Islam Translated: Literature, Conversion, and the Arabic Cosmopolis of South and Southeast Asia. Chicago and London: University of Chicago Press.

Robinson, Francis. 1997. 'Ottomans-Safavids-Mughals: Shared Knowledge and Connective Systems'. Journal of Islamic Studies 8/2: 151-84.

Schimmel, Annemarie. 1980. Islam in the Indian Subcontinent. Leiden: Brill.

Simon, Udo Gerald. 1993. Mittelalterliche arabische Sprachbetrachtung zwischen Grammatik und Rhetorik: 'ilm al-ma'ānì bei asSakkāki. Heidelberg: Heidelberger Orientverlag.

Steingass, Francis. 1977. Persian-English Dictionary. London.

Subrahmanyam, Sanjay. 1997. 'Connected Histories: Notes towards a Reconfiguration of Early Modern Eurasia'. Modern Asian Studies 31/3: 735-62.

- 2012. Courtly Encounters. Translating Courtliness and Violence in Early Modern Eurasia. Cambridge, MA and London: Harvard University Press.

Szuppe, Maria. 2004. 'Circulation des lettrés et cercles littéraires: Entre Asie centrale, Iran et Inde du nord (XVe-XVIIIe siècle)'. Annales: Histoire, Sciences sociales 59/5-6: 997-1018. Würsch, Renate 2018. 'Abū l-Fath b. 'Abd al-Hayy b. 'Abd alMuqtadir'. In Encyclopaedia of Islam, THREE, edited by Kate Fleet, Gudrun Krämer, Denis Matringe, John Nawas, Everett Rowson. http://dx.doi.org/10.1163/15733912_ei3_COM_22611, consulted online on 31 January 2018. 


\title{
6. BASTARDS AND ARABS
}

\author{
E. Khayyat
}

Herr, du sollst den Streit beenden, der die Welt entzweit.

So wie du bist haben unsere Alten den beschrieben, der es tun wird. Frieden müssen wir haben von den Arabern... Reinheit, nichts als Reinheit wollen wir...

Jackals, from Kafka, "Schakale und Araber"

Commenting on Ziya Pasha's (1825-1880) anthology Harabat, the great poet Tevfik Fikret (1867-1915)—one of the pioneers of modern Turkish poetry—suggests that "even the sahib-i fazl,," which is to say 'the author of [this] gift or treasure', but also, as Fikret underlines, "the father of [this] illegitimate child [...]," confessed to the shortcomings of his final product (Fikret, 1898). ${ }^{1}$ Ziya Pasha started off his anthology with disclaimers, explains Fikret, and announced his regrets already in the Introduction to Harabat "with a thousand pîç-tâb-ı derûn."

\footnotetext{
${ }^{1}$ Sahib-i fazll: sahib is literally 'master' or 'owner'. The expression could alternatively be read 'the recipient of this blessing or grace', fazl referring to Ziya Pasha's God-given talent, describing Ziya Pasha as blessed. In addition to 'that which is given as a gift or favour', fazhl, referring to Harabat, could be interpreted as 'the great service' Ziya Pasha provided. I use Ziya Pasha (1291-1292).
} 
Fikret thus comes unglued already in the second paragraph of his critical essay on Harabat, showing off his twisted command of Ottoman Turkish. He demonstrates what a poet could make with the words of elsine-i selase 'the three languages, i.e., Arabic, Farsi, and Ottoman Turkish', the tri-lingual combination of the Ottoman Empire. Derûn is 'deep' and pîç is 'bastard'; pîçtâb 'distress or trouble' and tâb 'strength, light, or sparkle', also the act of 'annealing or tempering', and much more. Pushing things a little, one could easily hear تاب as تبع or 'print', since corrupting (bastardising?) Arabic, in writing as in speech, is quite the Turkish habit. Ziya Pasha's three-volume anthology (mecmua-i müntehabât, in Fikret's vocabulary) of Ottoman Turkish poetry, which was one of a kind when it was published between 1874-1875, contains poems in elsine-i selase. Its multilingualism (avant la lettre, as it were) was considered its main shortcoming by Ziya Pasha's fellow reformists and revolutionaries, who were calling for the elevation of the oral tradition in vernacular Turkish over and against elsine-i selase around the time when Harabat was published. Vernacular Turkish was the cornerstone of the Ottoman Turkish future that these revolutionaries sought to build through their literary-political activism (Levend 1972; Lewis 1999). ${ }^{2}$ Instead Harabat covers and builds on Arabic and Farsi literary canons and focuses on Ottoman poetry under the influence of these traditions to develop a canon of modern Ottoman letters.

\footnotetext{
${ }^{2}$ The canonical history of the Turkish vernacular from the perspective of Turkish modernity is Levend (1972), which is somewhat teleologically minded. Also see Geoffrey Lewis (1999).
} 
How does Ziya Pasha express his regrets, then, according to Fikret? Through a thousand painful sighs from the depths of his heart? Through a thousand adopted bastards in his orphanage of an anthology? Through the displaced, bastardised poems of the old? Through Arabic and Farsi poems of time immemorial that Ziya Pasha adopted as his very own, perhaps? Through the poems that do not belong to us but that we have made our ownArabic and Farsi poems that, so deeply ingrained in our hearts and souls, are now part of our way of expressing ourselves, for better or for worse? Then again, what does Harabat show us when it sheds light on, prints, tempers the traits and movements in the depths of our souls? If the origins of Ottoman Turkish language, culture, literature, and self-expression-according to the logic of Harabat-might also be Persian and/or Arab, and thus perhaps even doubtful, what does that make of Ottoman Turks? Could the latter be the source of the anguish Fikret reads into Ziya Pasha's words?

Many before and after Fikret, including the giants of Turkish criticism, such as Namik Kemal (1840-1888) and Mehmet Fuat Köprülü (1890-1966), Riza Tevfik (1869-1949), and Ahmet Hamdi Tanpınar (1901-1962), scrutinised Ziya Pasha's Ottoman Turkish canon as it took shape in this unique anthology. ${ }^{3}$ They asked questions similar to the ones I summed up above, at times refuting the premises that guide Ziya Pasha's choices while acknowledging his ambition and great service, or sympathising with his politics while raising objections to some of his specific

${ }^{3}$ See Tahrib-i Harabat, 1303. Riza Tevfik's 'Harabat ve Harabati' was published in Yeni Sabah (1944). See also Fuad Köprülü (1917). 
choices. Yet almost every critic since Kemal has made a point of addressing our reformist Pasha's revolutionary agenda and his reactionary attitude in Harabat as paradoxical. It is high time we scrutinise the theologico-political premises underlying Ziya Pasha's sense of literary history to make better sense of this most productive paradox. Ottoman Arabic was central to the theologico-political horizon that shaped Ziya Pasha's branch of what I shall refer to as Islamicate humanism, just as Harabat had an absolutely crucial role to play in the history of this Islamicate humanism at large. Harabat both fulfils and destroys that humanism-it announces the end of Islamicate humanism right at the peak of its centuries-long, cross-cultural trajectory, hailing the beginning of a new era. Gerschom Scholem's pioneering vision on the paradoxical moments of Jewish history will guide us to account for this productive paradox.

Unfortunately, by focusing almost exclusively on the limited role that Harabat played in the history of modern Turkish and Turkish literary modernity, critics, scholars, and students of Ziya Pasha have obscured the immense potentials Harabat still carries. The pure 'Turkish vernacular' that Ziya Pasha's fellow reformists and revolutionaries, and Ziya Pasha himself at one point, sought to elevate for the future of the Ottoman people, was not a reality at that point in time, but more of an idea or an ideal to pursue. Harabat's emphasis on Arabic, Farsi, and Ottoman Turkish, or the tri-language of the Ottoman Empire over and against the ideal of a Turkish vernacular, articulates another, a much older idealism, while carrying that idealism to its radical conclusions. A review of Harabat's languages and literatures, and, 
finally, its Arabic canon, in the following pages will provide an opportunity to acknowledge these unaccounted-for aspects of Harabat, while raising an uncanny question: that of the relevance of Ottoman Arabic today.

\subsection{The Bastards}

Fikret's 1898 'Harabat'tan Bir Sahîfe', or 'A Page from Harabat', was a response to the reformist and/or nationalist critics of Ziya Pasha's anthology, who found the anthology's selection and multilingualism a little too reactionary. As mentioned, Harabat was published tri-lingually and covered the millennium-long history of Islamicate verbal arts in many of its genres and forms, from the qasaid to khamriyyat. The first volume, from which I have chosen a page to analyse closely in the concluding section of this essay, contains 37 Arabic, 38 Farsi, and 22 Ottoman Turkish qasaid. The curious thing is that, like Fikret and his other critics, Ziya Pasha was a reformist-a proto-nationalist of sorts, no less, and a member of the revolutionary Young Ottoman movement, who himself had a particular interest and investment in the vernacular, everyday, 'simple' Turkish, or Turkish as the tongue of the simple Ottoman folk.

About a decade before Harabat, when he and other likeminded reformists published a newspaper named Hürriyet in London exile, Ziya Pasha wrote a ground-breaking essay on reading 
Figure 1: Harabat title page

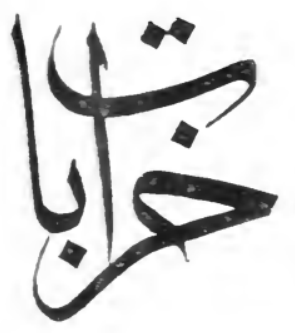

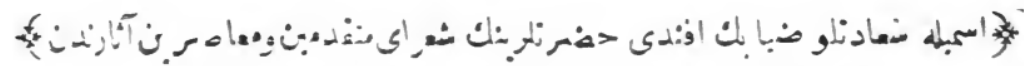

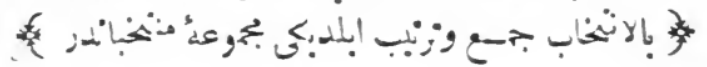

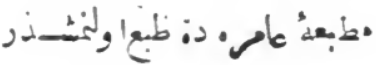

$$
\begin{aligned}
& \text { في شعبان }
\end{aligned}
$$


and writing in the Ottoman language. 'Poetry and Prose', which was meant to translate 'literature' in the modern, Western sense, is an essay about the insurmountable impossibility of drafting ground-breaking essays in Turkish. Not that our Pasha lacked the gift. But the language in which he wrote did not allow such a thing, the essay suggests.

Ziya Pasha and his comrades had fled the Empire because of their oppositional views, which were not perceived favourably by the Sublime Porte. They had become outcasts, living far away from their fellow Ottoman subjects. These concerned intellectuals, also known as the Young Ottomans, felt an urgency to reach out to those whom they took to be the true 'subjects' of Ottoman imperial history, which is to say the Ottoman multitude, to warn them of the difficulties ahead. The problem was not just that they had no option but to publish their oppositional views in the London-based Hürriyet, which was smuggled to Istanbul through the British embassy. Ziya Pasha and other luminaries, from our Pasha's perspective, had difficulty reaching out to the people even when they lived right in the heart of the Ottoman capital. The distance between the vernacular and their written, literary, Ara-

\footnotetext{
${ }^{4}$ Ziya Pasha's essay, 'Şiir ve İnşa ['Poetry and Prose']' was published in the London-based Hürriyet in 1868. For the story of the newspaper, see Mardin (2000). Among some sources about Young Ottomans and Ziya Pasha in this context are Ebüzziya (1973); Akçura (1981); Kaplan (1948) and Yetiş (2000), which has a comparative discussion of the pasha's essay and its significance. Additionally, Tanpınar (2006) addressed the significance of the essay on multiple occasions.
} 
bic- and Farsi-infused high Ottoman Turkish made literary address (in the modern sense), which is to say communicative action, or, more generally, mobilisation, practically impossible:

İşte bu sebebledir ki elân

Türkîde yok irticâle imkân

For this reason, in our day and age

Authenticity is not possible in Turkish (Harabat $1: \mathrm{v})^{5}$

In search of that vernacular, that pure medium, 'Poetry and Prose' challenged its readers to ask if Ottomans have, or ever had, a language of their own in which to produce poetry and prose free of Arabic and Farsi, and whether there existed a literature in that language, an archive of wordy material, per concrete evidence. The pasha responded in the affirmative, but with reservation, since he also seemed to admit that one cannot take this kind of thing as given, just as one cannot take the identity of one's biological father or mother as given.

Why else would he call for the standardisation of orthography for Ottoman Turkish, the language of the ruling Ottoman Turks, if not in search for a birth certificate of sorts? Our pasha also recommended the promotion of mass literacy, to turn to the streets of the Empire, to the oral tradition in the vernacular, where the living language of the ruling Ottoman Turks could perhaps be found. His thinking, therefore, was that the true Ottoman

\footnotetext{
${ }^{5}$ I translate ارتجال as 'authentic self-expression', relying on context here. In other contexts it can be translated 'speaking wittily extempore, successful improvisation, or clear extempore expression of what is in one's mind'.
} 
language, the live language of the living multitude, and its literature, were potentially out there, but in an immaterial, non-tangible way in the people's mouths. So were the Ottomans as a unique nation: out there, yet nowhere to be found in the flesh, as if their unique identity, language, and culture (as distinct fromyet similarly to-the French, the British, Arabs, or Persians) amounted to hearsay. For as of Ziya Pasha's day, Ottomans (unlike the French, the British, Arabs, or Persians) existed in an ephemeral way, or, rather, more like a promise or potential, or, better still, silenced and invisible. That potential had to be objectified and the promise fulfilled, and the literary-humanistic archive - the birth certificate-organised and printed in actual, material books so that Ottomans might rightfully acknowledge their father- or mother-tongue and raise their voice.

Once the living language was elevated in this manner, and all these other measures were taken, then the sort of address such as the one Ziya Pasha sought to draft would easily reach the addressee-the people-and the interpellation would be felicitous. The Turk then would stop being Turk in name only and turn to, come to the name Turk. When Ziya Pasha drafted the essay in London, however, none of these conditions, and not even the condition of a uniform orthography, had been met yet. What sort of other changes the measures he listed would incite, or whether or not the creation of the conditions Ziya Pasha desired-or the interpellation itself, for that matter-would amount to fabricating an Ottoman Turkish language, literature, and identity, did not seem to concern him at this point. In other words, he was not 
concerned with the validity of the premises justifying the engineering of a new media technology. The Ottoman masses had to be mobilised if the Empire was to survive, and mobilisation required a new media technology_of that much he was certain.

From the point of view of the future of the Empire, then, that "Türkîde yok irticâle imkân" at that point in time, or the present silence and invisibility of the vernacular Ottoman Turkish identity and tongue, appeared as an urgent problem to be addressed. What turns out to be problematic in this moderately optimistic, future-oriented point of view, which is emblematic of the haste that marks the late Ottoman intellectual universe, would appear in a completely different light when Ziya Pasha moved on to develop an alternative, strictly historical perspective on the very same issues. Ziya Pasha's call in 'Poetry and Prose' voiced the concerns of his generation, which feared the unforeseeable future unfolding before them with the hasty reforms, oppressive rulers, and silent masses of the Sublime State. Harabat, in turn, takes a pause, and views the same state of affairs from the perspective of the Islamicate past, offering a sort of intellectual history on the silence or invisibility in question.

Perhaps Ziya Pasha himself took a first step in pursuit of the prescriptions of 'Poetry and Prose' when he put together Harabat. One could consider this anthology, then, the birth certificate that he called for-one that he himself drafted after a decade of research.

He set to work with his own archive, which had enabled and motivated him to consider his cultural identity unique and distinct from any other. He apologises in his Introduction, drafted 
in verse, for his limited sampling bias, which Fikret does not fail to underline, but, at the same time, does not consider significant. ${ }^{6}$ Ziya Pasha organised the poems he grew up with, systematising, to the best of his ability, the one and only literary cultural archive of his era, collecting traditional verses in elsine-i selase. Harabat provides us with insight into the making of the traditional Ottoman intellectual and his/her lifeworld and, therefore, also outlines the fundamentals of the sort of humanism underlying such Bildung. The oral tradition in vernacular Turkish also figures in Harabat, but in a rather more critical manner, while Ziya Pasha of Harabat, looking back at his own intellectual journey, does not, of course, even consider offering translations of the Arabic and Farsi poems of his selection into Turkish.

Nor can he disentangle the centuries-old knots or cut off 'Turkish' poetry and prose from the Arabic and Farsi of his very own Bildung. In Fikret's terms, when Ziya Pasha, and, through him, the proto-nationalist Young Ottoman movement, look into their father's or mother's face from up close, they end up finding themselves in sorrowful doubt, at a paralyzing moment of decision, and yet before a future ripe for poetry as well. ${ }^{7}$

In the section of his "Introduction" to Harabat that addresses the motives behind his compilation of the poems, Ziya Pasha praises vernacular Turkish poetry for its educational value, describing his exposure to folk literature as an early station in his

\footnotetext{
6 Ziya Pasha's 'Introduction' (Mukaddime) was soon after published separately as Mukaddime-i Harabat (1311).

${ }^{7}$ The poetry of the sort I have in mind here is that of the poet in the

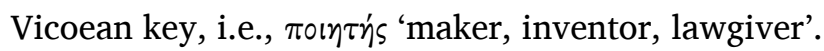


intellectual journey and an inspiration for his own early verse. What marks this moment in his intellectual journey, though, is some half-learned, childish pride, and inability to handle criticism:

Kim şïrime atsa tane taşı

Uğrardı benimle derde başı

Hicv idi muârıza cevâbum

Şemşir-i zeban idi kitabum

Whoever threw stones at my poems

Would get in trouble with me

Sarcasm was my response to opposition

Scimitar of the tongue my constitution (Harabat 1, iv)

One can surmise that folk literature in any language of the Ottoman universe could potentially serve the same purpose, which is initiation into culture. Mastery over cultural matter would require more than mere initiation. For soon after his exposure to folk literature, Ziya Pasha laid his hands on two diwans in Ottoman Turkish, the study of which proved to be a humbling experience for him. Then again even that was just another step in his intellectual trajectory. Only after reading Farsi poetry did he find true enlightenment, he admits, beginning to figure out what a poem is and what it takes to be a poet proper, or to claim mastery over words, speech, and culture:

Amma okudukda Gülistan'ı

Derk etmeğe başladım lisânı ${ }^{8}$

Yet only after reading Golistan

\footnotetext{
${ }^{8}$ The lisân at issue here is the 'poetic' or Farsi language.
} 
I began to understand the tongue (Harabat 1, v)

To be a poet one must leave behind the childish pride that comes with the gift, then-the gift of a mother tongue and talent. One must learn to look beyond and even overcome the self (Harabat 1 , xi). Talent is a must to be a poet, but it is only one of the conditions for being a poet proper. Talent needs to be cultivated through learning and morals, through something like a humanities education:

Şâni-i şurüt-ı şâiriyyet

Tahşil-i maârif ü fazilet

İlim olmasa şâir olmaz insan

Dilsiz söze kadir olmaz insan

The second condition for becoming a poet

Is the study of culture and manners

There is no poetry without wisdom

One cannot command words without tongues (Harabat 1, $\mathrm{x})$

The humanities training of this sort requires moving beyond Turkish for the Turkish pupil, beyond the oral tradition and more, as we shall see shortly. This is not to say that Harabat disregards issues concerning the state of Turkish that Ziya Pasha voiced in 'Poetry and Prose'. Again, Harabat simply reframes Ziya Pasha's earlier questions in 'Poetry and Prose'. Ziya Pasha leaves behind his terror at the unforeseeable future of the Sublime State, along with his youthful haste, resentment, and pride. He develops a new perspective on the circumstances he observes in Turkish, which reflects a peculiar historicism and even realism, in so far 
as Harabat was based on his own actual, material library and lived experience.

According to the Ziya Pasha of Harabat, the very nature of the Turkish tongue is corrupt, or bastardised, as Fikret would say, due to the immense influence of the Persianate cultural universe on Turkish and the insistence of some Ottoman poets on imitating the great Iranian masters in Turkish:

Taklid ile çün lisân bozulmuş

Evzân-ı arazi ğâib olmuş

Çıktıkça lisân tabiatinden

Elbette düsser fesahatinden

For imitation corrupted the tongue

Verses of the land vanished

The more the tongue betrays its nature

The weaker its ability for expression (Harabat 1, v)

The source of all the difficulties Ziya Pasha observes in Turkish and the weakness of the Ottoman Turkish tongue is the confusion that results from such influence corrupting the nature of Turkish. Instead of elaborating more on what the true nature of Turkish might be, Ziya Pasha of Harabat welcomes what he finds in his archive and interprets his contemporary moment of 'weakness' and corruption in the history of Turkish as a station on a centuries-long cultural trajectory. First, he suggests that the Turkish condition is not unique; that Iranians once imitated Arabs in the exact same way that some Ottoman gentlemen of his day imitated the Iranians:

Türki'de değil bu hâl evvel

Olmuş idi Fâriside muhtel

Anlar da edip lisânı tecdîd 
Etmiş Arab'a sühanda taklid

It is not in Turkish that this happened first

Farsi too once got corrupt

They too refreshed their tongue

And imitated the Arabs in discourse (Harabat 1, v)

Imitation leads to interesting outcomes in the case of Farsi. Its bond with Arabic only strengthens and eventually 'perfects' Farsi, enabling the Persianate cultural universe to dominate the Muslim world before the Ottoman Turks took the stage:

Zira Arabi lisânla evvel

Olmuş idi Fârisi mükemmel

For it was with the Arabic tongue

That Farsi reached perfection (Harabat 1, $\mathrm{x}$ )

Addressing what appears to be weakness in Ottoman Turkish requires not a search for the true nature of Turkish from this perspective, then, but to go beyond imitating Iranians, just as to get to the Persianate peak of Islamicate humanism, Iranians had to stop imitating Arabs, appropriated the Arabic archive, and produced in Arabic as well. The evident weakness of Turkish, similarly, required appropriating Farsi and reaching out all the way back to the source of learning to dig out wisdom.

The source of wisdom, the origin of learning, the ultimate reservoir of humanism in this mental theatre is Arabic. Arabic also serves as the measure of all things in this regard. It is not entirely clear whether Ottoman Turkish would be 'weaker' or stronger after appropriating Farsi and Arabic, or whether the goal here is to praise or condemn what Ziya Pasha regards as Turkish 
weakness or corruption. Then again, using his recurrent metaphors of the seas, rivers, and oceans, Ziya Pasha suggests that Turkish and Farsi are but two rivers when it comes to wisdom, while Arabic is the ocean:

Var ise de bazı fazla noksan

Evzân-ı Arab'dır anda evzân

Biz anlara nisbeten cedidiz

Güya ki Arablar'a hafidiz

Âşâr-ı Arab'dır ümm-i irfan

Bunlar iki nehrdir o umman

If we are deficient or excessive at times

Arabic metre is its metre [measure]

We are novices by comparison

Being supposedly Arabs' heirs

Arabic poetry is the mother of wisdom

It is the ocean: the other two, rivers (Harabat 1, v)

The continuity Ziya Pasha relies on here-from Arabic to Farsi and Ottoman Turkish-is based on the theologico-political horizon of Islamicate humanism and its sense of history, which I will address at length in the next section with Tanpinar's guidance. Suffice it to say that the obligation to study Arabic is the obligation to have a particular mindset, if not historical consciousness, for Ziya Pasha:

Şïr-i Arab'a tevessül eyle

Nahv ü lügata tevaggul eyle

Nazm-ı kudemâ vü fenn-i târih

Gül-nahl-i fesahate bün ü bih

Embrace Arabic poetry

Study its syntax and vocabulary 
The poems of the old and the science of history Are the root of this rose sapling of self-expression (Harabat $1, \mathrm{x}$ )

Harabat, therefore, is a literary historical quest that, with its peculiar realism, forced our pasha to contradict the revolutionary politics he articulated in his earlier, proto-nationalist call to zoom in on and elevate the Turkish of the simple folk. Harabat shares the observations about the state of Turkish that Ziya Pasha first voiced in 'Poetry and Prose', but, elaborating on a historical continuity leading to that state of affairs, it offers an alternative, more complex path to literary-political action for the future. It still calls for action, like 'Poetry and Prose', but to 'perfect', or democratise the Ottoman tongue in a different way-through a more rigorous investment in Islamicate humanism by way of completely appropriating the Arabic and Farsi languages, literatures, and libraries into the Ottoman Turkish lifeworld.

From Harabat on there are two paths before the Ottoman Turkish intellectual history. Either dive deeper into that ocean of harabat, devour that ocean of wine-more to follow on harabat and wine poetry-and have Turkish, Arabic, and Farsi get further ruined and bastardised; or set Ziya Pasha's archive, library, and that orphanage of an anthology on fire, claim poetic license for a new era, and start from scratch. Ziya Pasha comes to opt for the former, for, additionally, there is still a huge potential in Ottoman Turkish, according to him, when one considers it a fruit of Islamicate humanism.

If Arabic is the true ocean of our ancient wisdom where the Farsi and Turkish rivers must meet-flowing backwards if need be-it is potentially Ottoman Turkish, or rather elsine-i selase as 
the native-Ottoman tri-language, that is the ocean of an infinite future where Arabic might finally become one with Farsi and Turkish. The three of them then would dissolve into one another to create something completely unprecedented: an ocean of oceans (bahr-l â'zam as opposed to umman; Harabat 1 , ix-x). ${ }^{9}$ That would truly 'perfect' Ottoman Turkish—by dissolving it.

Then again, for some, Harabat's realism was so destructive, so ruinous, that none of this was feasible after its publication. For this realism had made both the Islamicate past and the Turkish future mere phantasy. I shall clarify how and why I read 'realism' into Harabat's mental theatre, and how this realism differs from realism in the Western sense, at the end of the next section. Suffice it to remember for now that Harabat's literary-political vision was based on Ziya Pasha's actual library and archive, his real and material books, as opposed to the ideal, the pure phantasy of a distinctly Turkish identity, vernacular, or literature. Let me first explain how and why Ziya Pasha's critics found his work 'ruinous'.

Ziya Pasha himself wrote traditional poetry-his verse Introduction to Harabat is of the same genre. He was truly a harabati. Harabat is both 'the tavern' and 'ruins', and it is the proverbial and real gathering place of poets (who are called the harabati literally 'the wasted') to sing poems, literally being ruined and laid waste with the divine ecstasy of the words of poetry or with

\footnotetext{
${ }^{9}$ Alternatively, for a recent discussion of Ziya Pasha's anthology within the context of world literature, see Arslan (2017).
} 
wine. ${ }^{10}$ The poems of the harabati directed one to the drunkenness of the wine, where one gave up on worldly concerns and differences to give in to whatever one was, and guided other perplexed, inquisitive souls to do so as well. This amounts to turning and turning in circles, like the whirling dervishes, to avoid reading too much into this world, and to go about one's business in divine ecstasy. Once, the word harabat in Farsi and Ottoman Turkish had a more general, mystical connotation within these parameters, but as the Ottoman Turkish literary modernity evolved, and especially after the immense impact of Ziya Pasha's Harabat, in Turkish the word came to mean more specifically the canon of pre-modern Islamicate poetry, as opposed to Turkish literature in the modern sense, while harabati came to refer specifically to the author of traditional poetry. Ziya Pasha's work and the stir it created would over time suppress the immensely rich connotations of the word harabat in Turkish, then. This is to

\footnotetext{
${ }^{10}$ On Islam and wine, see Wensinck and Sadan (2018), and also Ahmed (2016). Harabat once referred to both the proverbial gathering place of mystics, poets, and lovers of poetry, and the actual space of worship and meditation of the Sufis (tekke or hankah); see Uludağ (2017). Dabashi (2013) explains:
}

Persian literary historians have concurred that the word [kharabat] originally meant a 'house or tavern of ill repute' but was eventually appropriated by the mystics to mean a place that they frequent by way of suspending all hypocritical pretense to piety.... The idea is that there are places that you can frequent that will dismantle your beliefs, and yet, in doing so, will also restore your faith. The proverbial tavern in Persian poetry is that kharabat. 
say that if Ziya Pasha, with Harabat, contradicts his own revolutionary politics, and comes out as rather reactionary than progressive according to his own proto-nationalist vision, this is not to say that his Harabat is necessarily of the harabat of old either.

Some of his critics suggested that Ziya Pasha's scandalous work served as a bookend to the tradition, that Ziya Pasha's work at large did not open up new horizons and venues of action, but merely created an impasse. Harabat's path to harabat, accordingly, was a dead end. From this point of view, Harabat articulates the absence of a distinctly Turkish culture and identity (as distinct from Arabic and Farsi, to say the least) in Ottoman Turkish history not merely to terrorise Ziya Pasha's comrades. Its perspective on harabat also makes something new out of the material in Ziya Pasha's library, of his literary cultural archive. It makes out of a lively, mystical, proverbial gathering place, which was at once a place of worship and celebration, performance and deliberation, something that comes close to a canon in the European sense, or something like a proverbial cemetery. The OttomanTurkish literary cultural history Ziya Pasha framed, so that Ottoman Turks might know about their ancestry, turned the mystical harabat and its vibrant tradition into history, thereby ruining it, while it also ruined the reformist project to elevate vernacular Turkish and the nationalist vision of a future-oriented, Turkish cultural history. This latter judgment belongs to Namık Kemal, the poet-prophet of modern Turkey and one of Ziya Pasha's closest friends, whose Tahrib-i Harabat, meaning the destruction of the harabat or the damage Harabat brought about, was only the beginning of the torrent of criticism Ziya Pasha would receive in 
the coming decades. According to this school of thought, Ziya Pasha's work was ultimately 'ruinous', his Arabic and Farsi threatening to make out of the Turks mere bastards, helpless drunkards with no wisdom whatsoever. ${ }^{11}$

Yet "there is only Harabat," writes Fikret defending Ziya Pasha, "and non-other [sic] than Harabat"-that Harabat ruined nothing but remained, even almost three decades after its publication, the only edifice, the only anthology worthy of the name (Fikret 1898, 67). Whether one takes Harabat to be ruinous or regards it as an edifice that survived the test of time, it should now be clear that by all accounts Harabat marks a crucial moment of an extremely difficult, painstaking decision-a moment that lasted over half a century, no less. This is because, from the point of view of Ahmet Hamdi Tanpinar, Harabat both fulfils and destroys Islamicate humanism. That is how Harabat makes space for the articulation of modern Turkishness. I shall explain what this slightly more complex critique of Harabat's Arabic entails in the next section, titled 'The Rings'.

In the section after 'The Rings', titled 'The Arabs', we will see what the Ottoman Arabic of the sort we find in Harabat does to Arabic language and literature. For Harabat bastardises not only 'Turkish', but Arabic as well. With its peculiar canon of Arabic poetry, it takes us beyond any idea of Arabic language and literature as the language and literature of Arabs. Harabat's reactionary vision of Arabic could also be interpreted as a progressive model for the study of Arabic today. As if to embarrass our

${ }^{11}$ Thus concurs Köprülü (1917), for instance. Also see Bilgegil (1972). 
Figure 2: Tahrib-I Harabat title page

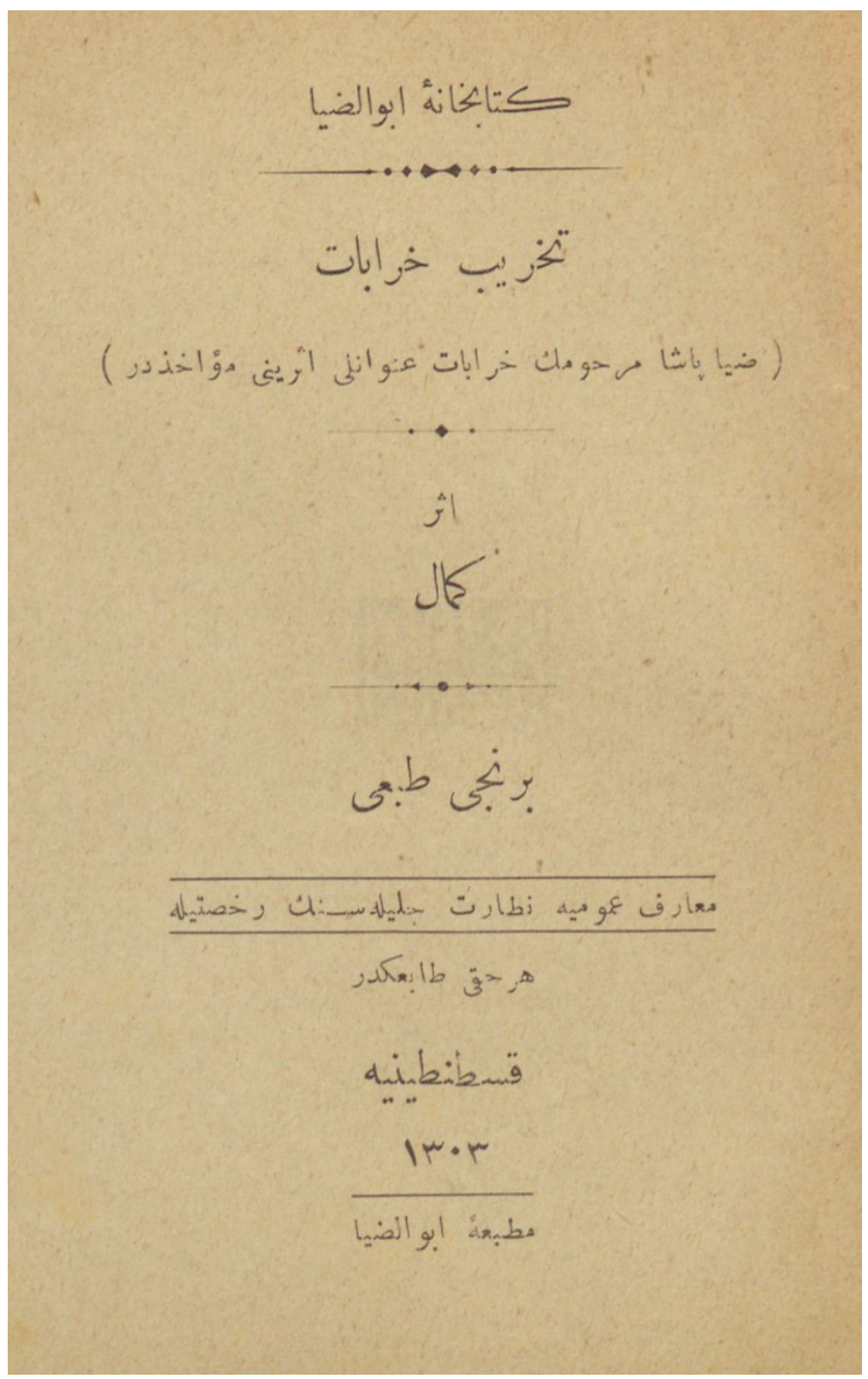


contemporary departments of Arabic in the US and elsewhere, Ziya Pasha's Arabic language and literature are Ottoman and Turkish, African, South Asian, and European all at once: it is 'global Arabic'.

\subsection{The Rings}

Young Ottomans Namık Kemal and Ziya Pasha, despite their revolutionary thirst, managed to cling to tradition, thus also to appear reactionary at times, thanks to their belief that the modern Western values and ideals they so admired had already been announced by Islam in its golden age. Modern democracy, for instance, was essentially the fulfilment of Islamic principles of faith for them. ${ }^{12}$ The Qur'ān was the source of the law before which all persons were already equal, which conviction they could not stop explaining over and over again by turning to the Book and the hadith. To this end they developed a new critical vocabulary and political concepts as based on the sources of sharia. Through biat (the 'election' of the caliph by the community of Muslims) they argued for the parliamentarianism of Islam, or through meshveret for the Islamic sources of a politics of consensus and so on and so forth (Mardin 1962; Çiçek 2010).

\footnotetext{
${ }^{12}$ Ottoman Turkish intellectuals-from the drafters of the Tanzimat declaration (1839), which announced the first major reforms towards modernity and secularisation, to Young Ottomans and revolutionary Young Turks-often emphasised the continuities between modernity and Turkish or Islamicate pre-modernity. Historians of the late Ottoman era often find such rhetoric disingenuous, and the piety involved in it as rather opportunistic or pretentious.
} 
Tanpınar's response to his predecessors' simultaneously revolutionary and reactionary, somewhat Eurocentric, yet equally Islamist mindset suggests that to have access to that mental theatre, one must be ready to rethink the fundamental concepts of the critique, beginning with history, historiography, tradition, and progress, and all these as they relate to the future and the past. Tanpınar does not agree with Ziya Pasha or Namık Kemal, yet he affords them the benefit of the doubt, and knows how to learn from them, too. This article is an attempt to learn from Tanpınar and Ziya Pasha in the same spirit.

Like Ziya Pasha, whom he regards as the "prototypical intellectual of the Tanzimat era," Tanpinar $(2006,19)$ thought that Ottoman Turkish letters followed "Arabic and Persian letters as the last great creative ring circling our common civilisation." This observation reads like a prose translation of the lines from Ziya Pasha's Introduction to Harabat that I have addressed above in a different context: Arabic, Persian, and Turkish are but three seas joining together in the Ottoman tongue to make up the ocean of oceans, or the ocean of Islamicate humanism (Harabat 1, ix-x). There is something distinct about the Ottoman language after all, yet this distinctiveness does not sit well with the thought of a history of a distinctly Turkish identity in the modern, European sense.

This distinctiveness has to do with a potential for (or the threat of, according to Tanpinar's double-dealing) radical fluidity or 'diffuseness', in Tanpinar's vocabulary, as opposed to homogeneity and groundedness. As mentioned earlier, one must trace the theologico-political premises underlying Ziya Pasha's thought of 
an ocean of oceans to get a better sense of the singularity of his Ottoman mindset. This is exactly what Tanpınar did, interpreting the cultural history of the 'Muslim Orient' (Müslüman Şark) against the background of the millennia-long development of identity and self-expression in the West, while ascribing a crucial role to Ziya Pasha in this history.

Tanpinar did not think that Islam was born as democracy avant la lettre. Yet he underlines that it is almost impossible to be guilty of blasphemy in Islam so long as one practices worship and verbally attests to the One-the practice or the performative, or the performance generally, being the core of this religion of the deed as opposed to faith (Tanpınar 1969, 41). This is why Islam could effortlessly accommodate countless contrary theological views and all sorts of mysticisms, Sufisms and orthodoxies alike, for Tanpinar.

There is indeed something radically democratic about Islam in its very essence, then, according to Tanpinar: already at its birth, Islam comes with a set of "democratic principles" (Tanpinar 1969, 43). Nevertheless, this democracy arrives "before its time," says Tanpinar, as if prematurely, and involves no sanctions or enforcement mechanisms to be politically relevant in modern times. In Tanpinar's view, these principles articulate an idea of justice without legal mechanisms; moreover, they do not allow historical, or rather historiographic space in the Islamicate intellectual universe for this idea to evolve.

Since Allah, unlike God in Christianity, is absolutely devoid of any human quality, and since Islam does not accommodate original sin and unequivocally denies the Incarnation as mere 
idolatry, it does not offer a human tragedy of salvation or allow for a human "notion of historical intentionality" to develop (Tanpınar 2006, 43). "Tragic realism" is not a possibility in the Islamicate lifeworld, nor is a tragic (as opposed to comic) view of mundane, human reality: "in a world that is no more than the variety of transient manifestations of the same absolute being that would always return to itself," there could not be anything of tragic import (Tanpınar 2006, 39). The Muslim Oriental does not "own up to the real," earthly life, but instead denies and ignores as immaterial its pomp, glory, poverty, wealth, or inequality (Tanpınar 2006, 44). Accordingly, "in our former civilization," ideally, "human beings would never even imagine standing before their own fate... the human found its true dimensions not in relation to this mundane world, which is nothing more than shadow play... but in his grand destiny in infinity" (Tanpinar 2006, 40). Now, paradoxically, this also means that Muslims once sought to be at constant peace with their earthly destinies in indifference-such indifference is the ideal to strive for in Islam.

Islam ends up preventing the emergence of class consciousness, moreover, and thus the class structure in the Muslim Orient according to Tanpinar, which in turn disables the "struggles that have been the heart and soul of progress in the West." This overly accommodating, a little too democratic attitude disables intellectual disagreement and trivialises opposition (Tanpinar 2006, 43). It renders all oppositional politics equally relevant or irrelevantas a result, even the alterity of the pre-Islamic world is easily subsumed into the Islamicate lifeworld. 
All the knowledge of "humanity's past was ascribed to Islam" and yes, "anachronistically" if need be. Greek antiquity was embraced as part of a struggle between Islam and blasphemy, explains Tanpinar, which was resolved for good with the arrival of the Muslim peak of human history and civilisation (Tanpinar 2006, 38-39). Plato, for instance, was admired for "having defended Islam" long before Islam's arrival. The true alterity of ancient, pagan cultures and civilisations was never recognised in Islamicate cultures. Needless to say, this indifference toward alterity, which is at once an ideal of diffuse or fuzzy self, could also be interpreted as an expression of a boundless humanism. ${ }^{13}$

Diffuseness and disintegration mark the Islamicate idiom in a variety of ways for Tanpinar. Above all, it is what structures Muslim Oriental self-expression. For instance, the pre-modern Muslim Oriental mind, ideally, had hardly any investment in prosaic composition, argues Tanpinar, although there are many exceptions, of course, and many historical movements that contradict the ideal. Regardless, this horizon has implications for temporal culture generally, but also for historiography and, eventually, for the development of a historical consciousness. Islamicate civilisational trajectory resembles "running backwards in time," which is to say that, while world history evolves, and identity and self-expression mature in other parts of the world, the Islamicate lifeworld progresses in the exact opposite direction for Tanpınar $(2006,35)$. While Tanpınar appears to regard this Islam

\footnotetext{
${ }^{13}$ The 'fuzziness' of premodern, non-Western identities has been an important issue for subaltern studies. The studies of Chatterjee (1993; 1996) are among the most often quoted in this context.
} 
as an obstacle on Muslim Oriental peoples' path to self-expression, his comparativism enables him to elaborate on the distance between two alternative horizons-generally speaking, one Western and the other Muslim Oriental-shaping different ways of being and saying, and leads him to surprising conclusions as well.

The essence of 'Muslim Oriental art' as a form of self-expression is the beyit (couplet), Tanpinar argues, slightly overstressing the Muslim Oriental difference: the fragmented couplet as opposed to the solid 'stanza' of European poetry. The plotdriven 'narrative' that binds statements into stories or novels, or the 'frame', visible or invisible, of the Western plastic arts, contradicts the basic premises of this aesthetics. Tanpınar argues that the second line of most couplets appears redundant, unnecessary or superficial. The saying in the first line gives a motif. The second line says almost nothing, interrupts the discourse by way of expressing a forceful submission to form. It follows the first line strictly formulaically, thereby making the overall couplet-the form-appear empty of content, transforming the words of the couplet into an embellishment of the motif introduced in the first line. One half of the couplet annuls the content promised in the other, thereby rendering the couplet primarily, or even purely style. Individual couplets resemble precious stones bearing motifs. Couplets, ideally, should not join together in a singular and meaningful, plot-driven work or composition, regardless of the length of the poem. This is where style meets political theology in Tanpınar's literary history.

Now, on the one hand, this ideal, Islamicate-poetic way of making things with words could not have enabled the writing of 
novels or histories proper because it was stuck to the intransitivity of the Muslim tongue. Tanpinar translates all this into the language of the society. After Louis Massignon, he argues that "there is no time in the Muslim Orient, but only moments" (Tanpinar 2006, 32). The sort of teleology that could enable plot-driven story-telling and narratives-history or fiction-does not sit well with this logic. Again, there are numerous exceptions to the rule, of course, and Tanpinar addresses them as well, but critically. "Islamicate civilization was forever bound to its golden age around which it was formed," writes Tanpınar, which is to say that its progression could not be easily reconciled with a future-oriented teleology (Tanpinar 2006, 38). There is progress here-backward as it may be, according to Tanpinar's reasoning-toward the golden age of Islam, and there are stages to this trajectory.

Let us get to the 'exceptions' to the rule or the deviations from the ideal I have been mentioning in passing, to make better sense of the stages in the development of the idea. Based on what we have seen, and given that the Islamicate mindset as Tanpinar has it is an obstacle on Muslim Oriental peoples' path to selfexpression, one would think that every deviation from this Islamicate path would be a welcome development from Tanpınar's perspective. Obviously, it is also a simple fact that histories, historical fictions, and plot-driven narratives abound in every era of Arabic, Farsi, and Ottoman Turkish as well. Then again, in Tanpinar's mind, it is as though the Islamicate ideal affects Arabic, Farsi, and Ottoman Turkish in different ways and to different degrees, and it is in Ottoman Turkish that we come closest to the 
ideal, for better or for worse. It is here that Tanpinar's conclusions become slightly ambivalent.

As expressed earlier, Ottoman Turkish letters follow "Arabic and Persian letters as the last great creative ring circling our common civilization" (Tanpinar 2006, 19). Despite the peculiarities of Islamicate-poetic writing described above, "[Arabs] had embraced some sort of narrative vision," writes Tanpınar-one that enables a sort of historical consciousness in the modern, European sense (Tanpınar 2006, 19). After all, pre-Islamic Arabic poetry, the Qur'ān, and later poetry and prose in Arabic at least involve linguistic continuity that easily lends itself to the building of a library in Arabic; not in the form of an actual, national library of sorts, but as an accumulation of books that reference and build on each other, i.e., an archive of writing. Persia-the second ring circling "our common civilization"-preserves its language and the library that it had built before Islam, and thus also the ability for self-expression, because Islam finds "Iranians in a particular geography and at the end of a war that concludes decisively." Yet the ability of Persians to Islamise themselves, to heed the Quranic call and merge with the Islamicate ocean is greater than the Arabs', accordingly, in so far as Islamised Persia embraces the Arabic archive as theirs alongside their own.

Then again, it is as though in Tanpınar's mind, these previous 'rings' fail to completely Islamise those whom they encircle. It is in Ottoman Turkish that we reach the peak-or the rock bottom-of this overall civilisational track. It is as though, in the final ring - the Oriental Turkish ring-Islam becomes more of what it was meant to be from the outset, fulfilling itself, again for 
better or for worse in Tanpinar's double-dealing. It is with the Turk-who did not come to the name Turk-that the Islamicate idiom sets on its most adventurous journey. Let us see what makes this all-engulfing, final creative ring so different.

There is a radical diffuseness, fuzziness to the Muslim Turk from the outset-some sort of separation from the origin, language, self, and earthly reality as well. It is this diffuseness that seems to have always already been the ultimate Islamicate-humanist horizon in Tanpınar's mind, as we have seen, i.e., the closest proximity to the 'golden age' of Islam, which remains in the past while shaping "our common civilization" traversing the future (Tanpinar 2006, 19).

Unlike Persians, Turks turn Muslim as small groups of people here and there, slowly and only gradually and as they move from one region to another. Until the 15th century, Turkic peoples only "struggled to control the changing conditions of life," moreover, which is why they could not even imagine building a library-a library in the sense that I have mentioned above, as an accumulation of books referencing and building on each other to enable, over time, a language of self-expression (Tanpinar $2006,46)$. Only after the 15 th century does the last great creative ring circling "our common [Islamicate] civilisation" emerge.

From the 15th century on, as Muslim Turks built their library and Islamicate idiom, they had already become a little too Muslim, a little too integrated into "our common civilization," expressing themselves, but only from within the boundaries of the common civilisation. Writers of "the last great creative ring circling our common civilization," thus, while writing in Turkish, 
also mastered, read, and wrote in the common languages of the Muslim world to build on its common civilisational archive. They read and wrote in elsine-i selase and even miraculously merged these tongues in their poems. As a result, 'alien' linguistic sensitivities-the prosodic laws of Arabic and Farsi-and vocabulary came to dominate Turkish self-expression.

Ottoman Turkish poets often borrowed words from the people's mouths, from the shared tongue of the common Turkish people, to mix them up with Arabic and Farsi and to subject them to the laws of these 'alien' tongues. Their art would thereby take those people, the humble Turks, beyond the cultural, linguistic, ethnic, etc. walls they were surrounded by and have them merge with humanity at large in the ocean of "our common civilization." Such was the social character of the harabati's craft: "The ability to express one's self with such ready-made elements, to say what one had to say in this manner, which is what our old poetry mastered, constitutes both the weakness and the astonishing attraction of the Oriental imagination" (Tanpinar 2006, 33).

At the peak of the history of this Islamicate cultural trajectory, Ottoman Turkish poetry, over-determined as it was by the influences of multiple traditions, had become so "abstract" (mücerret) that it was hardly communicative. Its "world of imagination" was more of a toolbox containing the imagery, figures, syntax, and vocabulary that had already become frozen over the previous centuries of our common civilisation. It was in fact more craft than art at this point (Tanpinar 2006, 31). It was precisely these conditions, though-this "abstract" and overdetermined, 
frozen language and its frozen world of imagery, motifs, and figures-that reduced this poetry to pure voice. Voice, in turn, enabled the most concrete (muayyen) praise of a most concrete beauty and provided us with a most concrete way of loving, too (Tanpinar 2006, 22). No made-up story, narrative, or history could produce or match such purity of voice. This voice, Tanpinar explains, was the most essential element and greatest accomplishment of Ottoman poetry-a voice that, like the Arabic callto-prayer that one still hears in Turkey, called for a particular way of being and living-in-common, constantly transforming the lives of people by way of finding its way to the people's mouths in recitations.

Having turned into pure style and voice over many a century, the language of Muslim Oriental poetry at its Turkish peak did not and could not depict mundane reality and its imperfections. Concrete reality was denied all imperfection in this tongue: "An entire inner world is visible in this literature, with gardens of roses and tulips painted in colors distilled through thousands of different kinds of alembics, with scents of spring and amber and all the refinements of a wisdom tired of pursuing life" (Tanpinar 1969, 55). Yet it continued to express and represent, as if in an endless recitation of a prayer in a partly familiar, foreign tongue, something far bigger, more real and equally this-worldly, with a clear voice: love for the Muslim way of life, for the real and everyday life of an entire Muslim humanity. It was the very "reflection on the individual of the order of a life-in-common whose entire history was built around the One and is nothing 
other than the violent and passionate struggle to defeat everything that is other than the One" (Tanpinar 1969, 25). Everything moves around the One in this mental theatre (Tanpinar 1969, 25). There is only One Source that anyone and everything came from and would return to.

As the entire world turns around the One, earthly fortunes and all other accidents being immaterial under His infinite power and beauty, the human selves become one, too. What is at stake here is the making of a "common life of mankind on earth" then, and in Tanpinar's Muslim Orient, poems and books were the building blocks for this edifice (Auerbach 1953, 552). Muslim Orient "constantly pushed its given limits" to reach out beyond the self, to undo the self dialectically to this end (Tanpinar 2006, 44). The cure that the poetry of the Muslim Orient prescribed to those who could not get over the self and come to terms with the infinite power and beauty of the One, for those who got distracted by the countless stories, wealth of events, and differences in this world, was wine. This is how Tanpinar accounts for the main figures and motifs of Islamicate letters: love, separation, desire, the passion and struggle to be one with the world and the One, and-perhaps most significantly-wine. Hence the significance of Harabat, of its multilingualism and its ocean-like coverage of the entirety of "our common civilization," and its ambition to merge Arabic, Farsi, and Turkish together with indifference toward earthly differences.

Ottoman Turkish poems, thus, lead to the fulfillment of what Tanpınar repeatedly describes as diffuseness and disintegra- 
tion, of the speaking self, of language and discourse itself, analogous to the way the beyit, itself an image of diffuseness, was based on the disintegration of its dual nature, and the disintegration of the overall work (Tanpinar 2006, 21, 32, 46). By the 19th century, written, poetic Turkish had hardly anything distinctly Turkish about it-it was not even called Turkish; thus, it disabled 'Turkish' self-expression in the distance between the written and living languages. This poetry, the only means of self-expression, destroyed almost everything distinctly Turkish about the Turk. It dragged the Turk closer and closer to the singular, common humanity of "our common civilization," as if to have the Turk deserve the designations that the Western imagination reserved for the simultaneously fabulous and terrible Turk of Orientalism. ${ }^{14}$ This 'Ottoman Turkish' discursive formation required "always to speak from without one's self, even to live outside one's own self.... This type of self-denial of the speaking self, a self-denial of such persistence" is "rare" indeed (Tanpınar 2006, 28).

Here we also have the two sides of a "latent conflict" Tanpınar traces in his history: the living Turkish of the humble and the language of Islamicate humanism (Tanpinar 2006, 20). The former lives secretly in people's mouths and can hardly make it to the archive; the latter carries in itself the traces of its struggle against the self and the living tongue, thus archiving that conflict as well. Until the 19th century, Islamicate humanism is always one step ahead of the living Turkish tongue, mind, and self within the parameters of the dialectic outlined above. In the meantime,

${ }^{14}$ See Khayyat (2018) for some commentary on this Turk and references. 
the gap between the living tongue and the written word, between the humble and the poet-historian, grows bigger and bigger. According to Tanpinar, in the late Ottoman era the distance between harabat's poetry and the language of the humble, illiterate, simple-Turkish-speaking Anatolian multitudes had become insurmountable. It is as if Ziya Pasha's traditional poems had gradually lost their social character and their voice. Toward the middle of the century there comes a moment when, no longer able to reach out to the life-in-common or to find nourishment there, this poetry turns into a mere affront to the self and nothing more. This is the moment when harabati turn into wasted souls producing bastards at best, just "insulting Turkishness," as it were.

By the time Harabat was compiled, right at the peak of a centuries-long crescendo, Ziya Pasha and his expression of pure joy at the persistent "self-denial of the speaking self" that, paradoxically, was also the very means of self-expression of the human of his Islamicate humanism, had become inaudible. The three volumes and languages of Harabat were simply inaccessible precisely to the simple-Turkish-speaking multitude. His humanism had left behind the very people whom it was meant to unite and bring into the fold of "our common civilization," of Muslim humanity. Despite having reached a peak, Islamicate humanism could no longer even come close to fulfilling its task at this point. In its flight "backward in time," it had left behind an entire future, the living tongue of the living people, and consequently, the people themselves. This is to say that the figure of the 'fabulous' Turk, finding perfection in ultimate diffuseness in Ziya Pasha's 
Harabat, also announces the end of the Islamicate humanism of "our common civilization," making space for the modern Turk.

\subsection{The Arabs}

This interpretation of Harabat from the point of view of Turkish modernity and as the 'fulfilment in destruction' of Islamicate humanism might remind some the readers the way in which the great Gerschom Scholem (1973) interpreted another moment in Ottoman history, but from the point of view of modern Jewish history. I have in mind Scholem's disgraced messiah, Sabbatai Sevi of Izmir. For Scholem, modern Jewish history begins with Sabbatai's conversion to Islam, which left this messiah's followers with one of the most difficult paradoxes in the history of religion. From Sabbatai on, salvation becomes a strictly this-worldly matter in Jewish thought for Scholem, Sabbatai's antinomianism being more of a tragic inevitability than mere disaster. Needless to say, Sabbatai's apostasy is not the end of Jewish history for Scholem, nor do I wish to suggest that Harabat is the end of the history of Islam or Turks. The point is that both Sabbatai Sevi and Ziya Pasha mark turning points in their respective cultural historical trajectories. There is no doubt that the theologico-political horizon of Harabat belongs to an earlier moment in Islamicate cultural histories, a moment that since the publication of Harabat, has become history, and in part thanks to Harabat.

This analogy should clarify the way in which I interpret Harabat here: just as Scholem had a keen eye on the ways in which Sabbatai fulfilled pre-modern Jewish history while destroying it, opening up a new horizon for a variety of Jewish futures, 
so Harabat is capable of guiding us today as the yardstick that it is, exposing us to a bygone horizon for a number of possible Islamicate futures. Only some of those 'futures' came to take hold of our present. This is to say that it is important to underline the potentially enabling aspects of Harabat's mental theatre as we observe the way in which it serves as a bookend to a centurieslong history. This is how, in the footsteps of Tevfik Fikret, I open 'a page from Harabat' here.

Fikret opens a random page to prove the anthology's worth, hence the title of his essay. The page that I have reproduced here is not random like the one Fikret chose: it is a page from the table of contents of the first volume of Harabat. The page lists Ziya Pasha's choice of canonical Arabic qasidahs that are as indispensably Ottoman Turkish as the canonical qasidahs in Ottoman Turkish in his mind. Under the title 'el-Qasâidü'l-'Arabiyye', the page gives us a sense of the canon of Ottoman Arabic literature, which is quite different from the canon of Arabic literature we teach today in contemporary academia.

Let us start with some of Ziya Pasha's remarks, which put this page, his Ottoman Arabic canon, or his Ottoman Turkish bastardisation of the canon of Arabic poetry, into context. His verse Introduction to the anthology contains separate sections that describe the different statuses and statures of Turkish, Persian, and Arab poets within the Ottoman cultural universe. The section 
Figure 3: Table of contents from Harabat

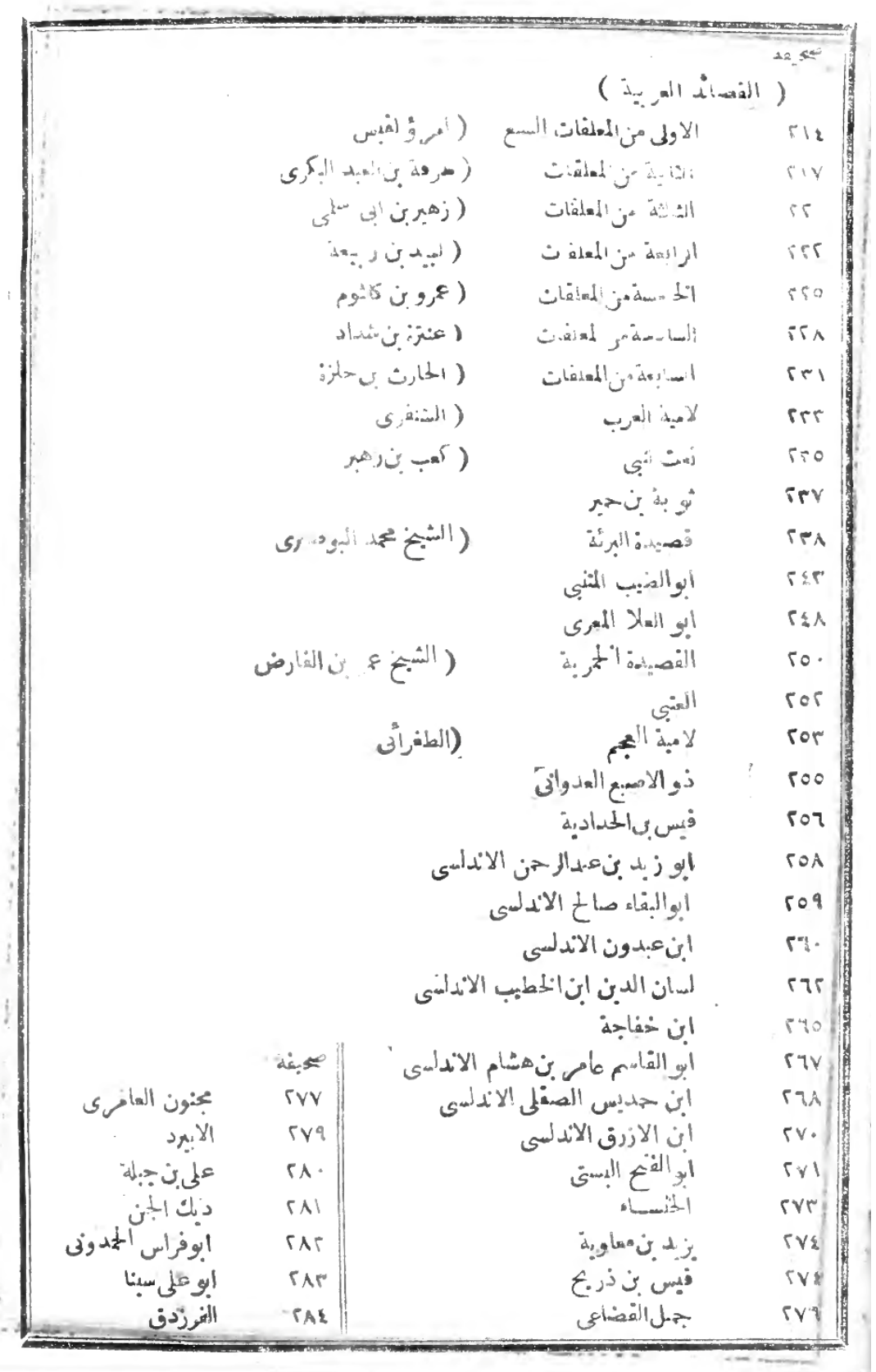


titled 'Ahval-1 Şuara-yı Arab' determines three eras for Arabic poetry: primal, middle (or mediocre), and recent. Alternatively: preIslamic, Islamic, and contemporary. Pre-Islamic Arabic poetry is that of al-Rāwiya's seven poets, the Mu'allaqat, or the suspended odes. There is nothing surprising here, of course. What is surprising is the way Ziya Pasha perceives these poets.

Given my description of the political theology that found its penultimate expression in Harabat, one might assume that our pasha's 'reactionary' outlook would lead him to look down on the $M u$ 'allaqat or perhaps attempt to Islamise-or why not, even exclude the pagan Arab poets from his anthology altogether. Not only does Harabat embrace the $M u^{\prime}$ 'allaqat wholeheartedly, it also appropriates them, making the quintessentially Arabic seven odes Ottoman Turks' very own, while Ziya Pasha just cannot sing enough praises for them:

Hakka ki Muallât-ı Seb'a

Hayret virir âşinâ-yı taba

Anlarda hakâyı-ı belagat

Anlarda menâbi-i fesahat

Kuran eğer etmeseydi iskât

Bunlar idi eblâğ-ı makâlât

Truthfully the seven suspended

Are a source of wonder for the learned

At times the truth of rhetoric

At others the source of eloquence in expression

Had the Qur'ān not taken them down

They would remain supreme articulation (Harabat 1, xxiii) 
Then comes the Qur'ān. The miraculous Book, or the miracle of the Qur'ān, brings about nothing less than destruction to the poets of the old, to those great men who, along with their $\mathrm{Mu}^{\prime} a l-$ laqat, lose their lustre vis-à-vis the penultimate Poem:

Mahv etdi anı Kitab-i Muciz

Zâil oldı güneşle yıldıı

The miraculous book destroyed their moment

The sun and the stars then expired (Harabat 1, xxiii)

This is because the beauty and originality of the Book's poetry, according to the doctrine of $i$ (jaz al-Qur'ān, or 'the inimitability of the Qur'ān' are bound to remain unmatched forever. ${ }^{15}$ After all creaturely talent is no match to the power of God:

Kur'an ne aceb olursa faik

Mahlûka şebih olur mu Hâllk

The superiority of the Qur'ān can only be a wonder

How could the mortal match up to the Creator (Harabat

1, xxiii)

It is not only the Almighty's power that is the issue here. Once the Qur'ān takes the stage, the Book elevates Arabic to its ultimate peak-and this peak, or the beauty of Quranic Arabic, does not belong exclusively to some crafty loquacious men and women of good fortune and stature. That language and that poetry belong to anyone and everyone.

On the one hand, from then on Arabic is 'level' or 'smooth', as opposed to oscillating between the great performances of one

\footnotetext{
${ }^{15}$ For a general introduction to the topic, see Martin (2019). For an elaborate introduction, see Larkin (1998), and Rahman (1996).
} 
great orator or another and the Arabic of the simple, illiterate folk. On the other hand, from the Qur'ān on, anyone and everyone is a poet.

What Muslims celebrate every laylat al qadr is not only the power of God Almighty. ${ }^{16}$ Every year Muslims remember and celebrate 'the night of empowerment', or the night when the revelation began in the depths of a cave, as the illiterate Prophet miraculously learned to read/recite the penultimate Poem to share it with humanity as a whole, including the illiterate majority or the simple folk. The ultimate 'message' of the Qur'ān, then, is that we can all be poets-that the Qur'ān gives us voice:

Ol rütbe Arab lisânı emles

Ez-tab ile şâir anda herkes

At this stage the Arab tongue goes smooth

With its lustre turns everyone a poet (Harabat 1, xxiii)

Thus, with the Quranic (and literary-humanistic) revolution, Arabic becomes radically democratised, as it were. Ziya Pasha's way of building a hierarchy between different stages of Arabic poetry proves his indebtedness to this very traditional, yet hardly ever discussed, aspect of the Muslim Mind and the literary politics of the Qur'ān.

For Ziya Pasha does not just appropriate the pre-Quranic Arabic $M u^{\prime}$ allaqat, but goes so far as to take the logic of the Quranic revolution to its radical conclusions when he continues to draw a rigorous hierarchy in his interpretation of Islamicate Arabic poetry.

\footnotetext{
${ }^{16}$ For a general introduction see Marcotte (2018).
} 
He does not feel obliged to hold in high regard Arabic poetry drafted by Muslims in his evaluation out of religious concerns, but rather prioritises the idea of poetry as it took shape with the Qur'ān, or the very politics of literature, as it were, of the inimitable Qur'ān. For instance, right after the miracle of the Quranic revolution, things go south in Arabic. The middle, or Islamicate Arabic poetry in Ziya Pasha's periodisation is also flat out mediocre in comparison to pre-Islamic Arabic poetry, and it starts with the coming to power of Umayyads:

Andan sonra gelen kabile

Başlar Emeviyye devletiyle

Ancak zâil olup bedâvet

Yokdur bu takımda eski lezzet

The tribes that come after

Start with the Umayyad State

Yet with the end of the badawi ways

This new folk no longer please (Harabat 1 , xxiv)

Here the problem is that a dynasty gets established in Damascus, betraying the political-theological horizon and the literary politics of the Qur'ān. This ends up damaging Arabs morally, equates the Islamicate idea of freedom to bondage, and transforms Arabic poetry into mere worship or praise of power:

Çün Şam'da saltanat kuruldu

Ahlak-ı Arab da fasid oldu

Mecidd oldu redâ ete muhavvel

Hürriyet esarete mübeddel

Bünyân-ı duruğ olub müesses

Medh-i ümerâya düşdü herkes

For a dynasty was founded in Damascus 
And left Arabs morally damaged

Evil replaced sublimity

Freedom became slavery

A wall of lies was erected

All began to merely praise the powers that be (Harabat 1 , xxiv)

Moreover, Muslim conquests mix Arabs with non-Arabs, which renders 'secular' Arabic less poetic, a little too levelled perhaps, even if out of necessity. Arabs become one with the اعجام (unidiomatic, vulgar-tongue-speaking) and the power of Arabic poems diminish:

Icem ile oldular muhâlit

Etdi bu da kadr-i şiiri sakıt

They mixed with the vulgar ones

And this diminished the power of poems (Harabat 1, xxiv)

Yet this state of affairs translates into the empowerment of Farsi poems, the two seas of Arabic and Farsi joining together to open a new chapter in the history of Islamicate humanism. Moreover, while Farsi becomes empowered thanks to its encounter with Arabic, this does not mean that Farsi becomes the exclusive literary language of the new era: Iranian poets drafting their verse in Arabic take the stage at this point, Iranians inheriting the glorious literary Arabic past and returning Arabic its poetic lustre.

As we have seen in the previous section, this second ring of Islamicate humanism would later meet its end when the Ottoman Turkish ring comes to encircle both Farsi and Arabic. Ziya Pasha's 
canon of Arabic poetry reflects a continuity that constantly underlines this dialectic. I would like highlight some of his choices to make this point clearer.

I will not dwell on all the great Arab poets whose works we still consider part of the Arabic canon today and who also take their rightful place in this anthology, but instead underline the choices that make Harabat unique in its strategy. Right after the Mu'allaqat, Ziya Pasha's anthology gives us Lāmiyyāt 'al-Arab by the quasi-legendary poet of the pre-Quranic universe, namely AlShanfarā. Not much later, though, we find Lämiyyāt 'al-Ajam by Al-Togharayi of Isfahan in Harabat's canon of Arabic poetry, which was Al-Togharayi's response to Al-Shanfarā. Ziya Pasha amplifies Al-Togharayi's voice with his choice to reflect the sort of continuity he had in mind as the history of a developing Islamicate humanism.

Then comes a rather more surprising and obvious set of choices that bring us to the moment of the Europeanisation of Arabic. Out of thirty-seven poets in Ziya Pasha's Arabic canon, eight of them, which is to say almost a quarter, are from Spain: Ebû Zeyd bin 'Abdu'r-rahman al-Andalusî, Ebu'l-Beqâ Sâlih alAndalusî, Ibn 'Abdûn al-Andalusî, Lisânu'd-dîn Ibn al-Hatîb alAndalusî, Ibn Hafâce, Ebu'l-Qâsım 'Amir bin Hishâm al-Andalusî, Ibn Hamdîs al-Sıqıllî al-Andalusî, and finally Ibn Al-Azraq al-Andalusî.

Other choices of Ziya Pasha, for instance, to include in the canon Abd al-Salam Ibn Raghbân al-Himsî's—-known as Dik alJinn of Homs-suggest that our Pasha did his best to cover as 
Figure 4: 'Ahval-1 Şuara-yı Arab’ title page

\begin{tabular}{|c|c|}
\hline 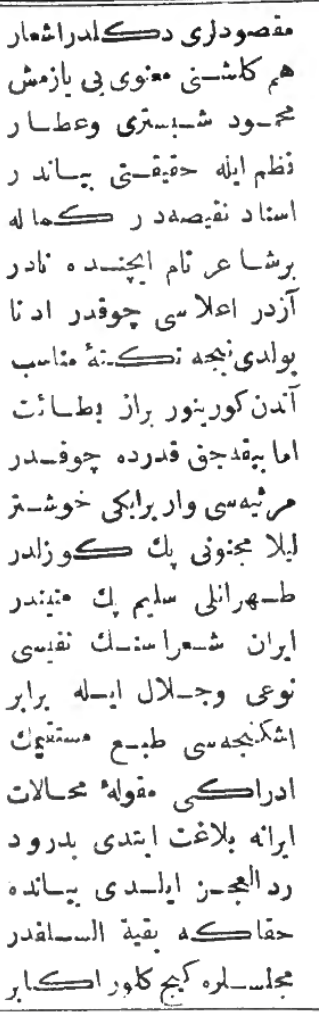 & 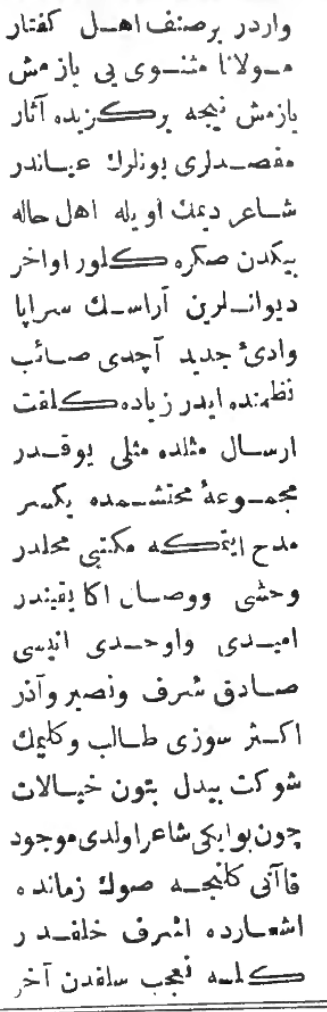 \\
\hline \multicolumn{2}{|c|}{ احوال شعراى عرب } \\
\hline 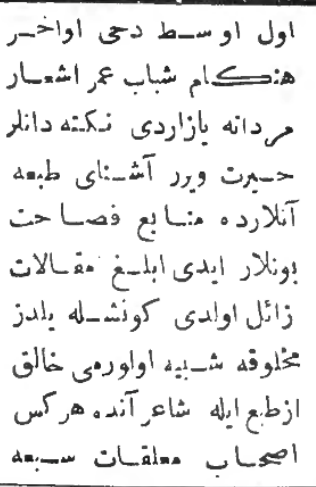 & 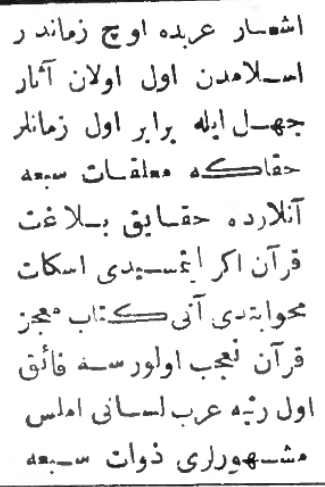 \\
\hline
\end{tabular}


much ground as possible and had an almost geographic and inclusive vision as he sought to provide a genealogy of the globalised Arabic of his times. Dik al-Jinn, a contemporary of Abu Nuwas and one of the masters of Abu Tammam, is hardly studied along with these illustrious figures, but was included in Harabat probably because of his famously ruinous ways, his drunkenness and debauchery.

Thus, in Harabat step by step the glorious tongue of the miraculous Book, or Quranic Arabic, becomes globalised, as it were-not simply through Arab conquests or 'colonialism' of one sort or another, but by appropriations of Arabic by the newly Islamised masses of the world, and/or through the bastardisation of Arabic, to go back to Fikret's terms. In other words, if modern Turkish is to be analysed within the context of a broader history of vernacularisation-vernacularisation of writing, of knowledge, and of power-then elsine-i selase must be interpreted within the context of the vernacularisation of Arabic itself. The latter, despite being the heart and soul of Islamicate intellectual histories more generally, is hardly ever addressed seriously by critics.

Arabic may not be the only language that went through vernacularisation of this order. Perhaps one might be so creative as to lay the grounds for comparing Ottoman Arabic to medieval Latin, or the 'Middle Latin' of 'Catholic cosmopolitanism'. I was more interested in elaborating the unique character of Arabic from the point of view of the late Ottoman intellectual universe, and the very specific theologico-political context that nourished 
this universe. Additionally, it may be the case that the vernacularisation of Arabic as a theologico-political matter (or of Latin, for that matter) does not sit well with, or cannot even have a place in, our modern historical narratives of vernacularisation and the democratisation of language. This is the reason why I welcome Fikret's vision and prefer the term 'bastardisation'.

Let me be clear that the bastardisation in question is no mere metaphor here: Harabat's Arabic contains many errors and typos, some of which could be considered ruinous mistakes in a dissertation on Arabic poetry today. For instance, Harabat has the name of one of the greatest figures of classical Arabic poetry, namely Abu Firas al-Hamdani's name in this table of contents as or al-Hamdouni. Then again, with respect to the liberties and limitations that Ottoman Turkish appropriation of Arabic reflect within the overall context of Islamicate humanism, this is hardly surprising-suffice it to say that one of the most popular names in modern Turkish is Mehmet, and Turkish armies are known to consist of mehmetçiks or 'little Mehmets', from the prophet's name, محمد.

There is no doubt that Harabat was an imperialist, Ottomanist and also 'Islamist'-and 'Sunni'-although this is beyond the scope here. It reflects a certain degree of bias and bigotry, no doubt, especially when it is considered an anthology of Islamicate or even pan-Ottoman poetry and literature, and given what it lays claim to and appropriates and what it excludes. It merely reflects the ruling Muslim Ottoman Turks' self-perception at a crucial moment in the history of the Ottoman Empire. With its emphasis on the Islamicate pasts, and the insistence on the place of Ottoman 
Turks in Islamicate history, Harabat is at the same time an Islamicate-humanist response to the burgeoning Turkish nationalism.

When Harabat was published, the ideal of a pure Turkish vernacular was still in the process of taking shape in the minds of revolutionaries and reformists, among whom we must count Ziya Pasha himself, as I have explained. The pure Turkish vernacular was not a reality yet, but at best a literary-political ideal. For no one wrote or spoke that pure vernacular. Arabic never became one with Farsi and Turkish in that ideal Ottoman Turkish tongue, or rather in elsine-i selase as the native-Ottoman tri-language. No one wrote or spoke that language either, and therefore, it, too, was a literary-political ideal. Both vernacular Turkish and elsine-i selase as the native-Ottoman tri-language were ideals, then-and they nourished two conflicting ideologies.

Clearly Harabat presents Ottoman culture and literature as the peak of Islamicate civilisation, and in that there is a degree of Ottoman Turkish pride and nationalism. This said, it is the paradoxical—most productively paradoxical—nature of this bias and pride that I find more interesting, and more instructive as well, with respect to the study of Islamicate pasts. Let me summarise this paradoxical condition once again.

In the mental theatre of Harabat, Ottoman-Turks stand right on top of the peak of the history of Islam. They are the perfect Muslims right at the end of that history, but only in so far as they are the most selfless, only in so far as their 'identity' and distinctiveness amount to the penultimate self-denial that fulfils the Islamicate-humanist ideals within the parameters I have outlined above with Tanpınar's help. In other words, what we have 
here is also a politics of 'anti-identitarianism' that necessitate religiously systematic acts of self-denial-acts of literature no less-in favour of a common Muslim humanity. "This type of selfdenial of the speaking self, a self-denial of such persistence" is "rare" (Tanpınar 2006, 28).

This is also what Harabat reflects with its Arabic canon. Paradoxically, then, the degree to which the Ottoman Turks could distance themselves from everything that made them a unique and distinct collectivity, the readiness with which they embraced Arabic and Farsi as their own at the expense of a unique culture, language, and identity, and the fanaticism with which they embraced the Islamicate-humanist ideals to develop a language and literature that over time would become completely self-destructive, make them unique and distinct and place them right on the peak of this civilisational track.

How inclusive this 'self-denial' was or could have been is another question-suffice it remember, though, that in the context of Ottoman Arabic, the appropriation of pre-Quranic Arabic and the pagan $M u^{\prime}$ allaqat, notwithstanding recognition of their alterity, displays at least an attempt to take the logic of self-denial in question to another level and move toward embracing nonMuslim antiquity in the name of an Islamist politics. This Islamism beyond Islam, which is in no way modern or unique to Ottoman Turkish outlook, was perhaps on the path toward an even more inclusive humanism within the history of Islamicate civilisation.

For the Islamist-humanist readiness to embrace the other's language and words as one's own did require Ziya Pasha to take 
other steps in that regard. The ambition to always look beyond and eventually overcome the self, having paved the way to what Tanpınar describes as Ottoman Turkish 'self-denial', additionally requires learning European languages in the present for our pasha: Ister isen anlamak cihan Öğrenmeli Avrupa lisânı Etmiş orada fünün terakki Tahsilden eyleme tevakki Bilmek gerek andaki funünu Terk eyle taassub-u cününu Ansız kişi tâm şâir olmaz Bir kimse lisânla kâfir olmaz If you wish to comprehend the world You must learn European tongues

Science has progressed there

Never fear its study

You must know the science of the present

You must avoid fanaticism and bigotry

Without the present there is no poetry proper

Learning a tongue is no apostasy (Harabat 1 , xi)

But let us go back to Harabat's Ottoman-Arabic canon. With the 'Ottoman Turkish' Mu'allaqat, we observe an exemplary moment in the history of Islamicate humanism. In conclusion, I contend that Ziya Pasha's canon of Arabic poetry as a whole is another extraordinary achievement that perfectly articulates the basic premises of what I am tempted to call 'literary-political Islam'. This literary-political Islam, with its 'reactionary' vision of Arabic, could also be a progressive model for the future of the study of Arabic today-as 'global' Arabic. 


\section{References}

Ahmed, Shahab. 2016. What Is Islam? The Importance of Being Islamic. Princeton, NJ: Princeton University Press.

Akçura, Yusuf. 1981. Tanzimat Edebiyatında Türkçülük İleri: Şinasi ve Ziya Paşa. Ankara: KB.

Arslan, Ceyhun. 2017. 'Canons as Reservoirs: The Ottoman Ocean in Ziya Pasha's Harabat and Reframing the History of Comparative Literature'. Comparative Literature Studies 54 (1): 731-48.

Auerbach, Erich. 1953. Mimesis: The Representation of Reality in Western Literature. Translated by Willard R. Trask. Princeton, NJ: Princeton University Press.

Bilgegil, Kaya. 1972. Harabat Karşısında Namık Kemal. Istanbul: Irfan.

Chatterjee, Partha. 1993. The Nation and Its Fragments: Colonial and Postcolonial Histories. Princeton, NJ: Princeton University Press.

— 1996. 'The Manifold Uses of Jati'. In Region, Religion, Caste, Gender and Culture in Contemporary India, vol. 3, edited by T. V. Satyamurthy, 281-92. Delhi: Oxford University Press.

Çiçek, Nazan. 2010. The Young Ottomans: Turkish Critics of the Eastern Question in the Late Nineteenth Century. New York and London: Tauris.

Dabashi, Hamid. 2013. Being a Muslim in the World. London: Palgrave Macmillan.

Kaplan, Mehmet.1948. Namık Kemal, Hayat ve Eserleri. Istanbul: İstanbul Üniversitesi Edebiyat Fakültesi Yayinlari. 
Khayyat, Efe. 2018. Istanbul 1940 and Global Modernity. London: Rowman \& Littlefield.

Köprülü, Fuad. 1917. 'Harabat'. Yeni Mecmua 10: 186-88.

Larkin, Margaret. 1998. 'The Inimitability of the Qur'ān: Two Perspectives'. Religion and Literature 20: 31-47.

Levend, Agah Sırrı. 1972. Türk Dilinde Gelişme ve Sadeleşme Evreleri. Ankara: TDK.

Lewis, Geoffrey. 1999. The Turkish Language Reform: A Catastrophic Success. Oxford: Oxford University Press.

Mardin, Serif. 2000. The Genesis of Young Ottoman Thought. Syracuse, NY: Syracuse University Press.

Marcotte, Roxanne D. 'Night of Power.' Encyclopaedia of the Qur'ān, edited by Jane Dammen McAuliffe. http://dx.doi. org/10.1163/1875-3922_q3_EQSIM_00299, consulted 19 July 2018.

Martin, Richard C. 'Inimitability'. Encyclopaedia of the Qur'ān, edited by Jane Dammen McAuliffe. http://dx.doi.org/ 10.1163/1875-3922_q3_EQCOM_00093, consulted 19 July 2018.

Pasha, Ziya. 1868. 'Şiir ve İnşa'. Hürriyet 11, September 7: 4-8.

—. 1291-1292 [1874-1875]. Harabat. 3 vols. Istanbul: Matbaa-i Âmire.

—. 1311 [1893]. Mukaddime-i Harabat. Istanbul: Matbaa-i Ebüzziya.

Rahman, Yusuf. 1996. 'The Miraculous Nature of Muslim Scripture: A Study of 'Abd al-Jabbār's Ijjāz al-Qur'ān'. Islamic Studies 35: 409-24. 
Scholem, Gershom. 1973. Sabbatai Sevi: The Mystical Messiah, 1626-1676. London: Routledge Kegan Paul.

Tanpınar, Ahmet Hamdi. [1946] 2006. Ondokuzuncu Asır Türk Edebiyat. Istanbul: YKY.

—_ 1969. Edebiyat Üzerine Makaleler. Istanbul: MEB.

Tevfik, Ebüzziya. 1973. Yeni Osmanlılar Tarihi. Istanbul: Kervan. Tevfik, Fikret. 1303 [1886]. Tahrib-i Harabat. Istanbul: Matbaa-i Ebüzziya.

—. 1898. 'Harabat'tan bir Sahife'. Servet-i Fünûn 395: 67-71.

Tevfik, Riza. 1944. 'Harabat ve Harabati'. Yeni Sabah 2372, December 29: 6 .

Uludağ, Süleyman. 'Hankah'. Islam Ansiklopedisi. http://www.is$\underline{\text { lamansiklopedisi.info/?idno }=160068 \& i d n o 2=c 160028 \# 2}$, consulted 17 July 2017.

Wensinck, A. J., and Sadan, J. 'Khamr'. Encyclopaedia of Islam, Second Edition, ed. by P. Bearman, Th. Bianquis, C. E. Bosworth, E. van Donzel, W. P. Heinrichs. http://dx.doi.org/ 10.1163/1573-3912_islam_COM_0490, consulted 19 July 2018.

Yetiş, Kazım. 2007. Dönemler ve Problemler Aynasında Türk Edebiyat. Istanbul: Kitabevi. 


\section{READER}





\title{
1. BODL. MS. HEB. C. 72/18: A LETTER BY ISAAC BAYT 'ATTṬĀN TO MOSES B. JUDAH (1480S)
}

\author{
Dotan Arad and Esther-Miriam Wagner
}

\section{Transcription}

\section{Recto}

1.

יודה

2.

3.

4.

5.

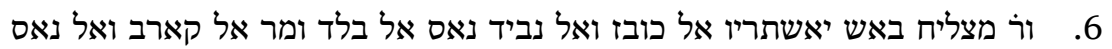

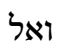

7.

8.

9.

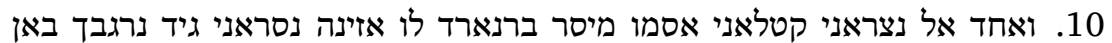

תאקף

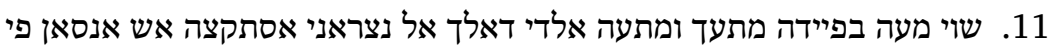

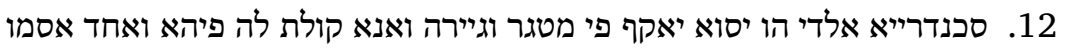

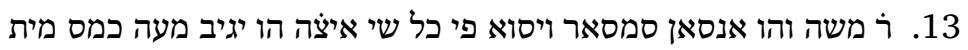

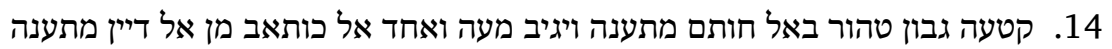

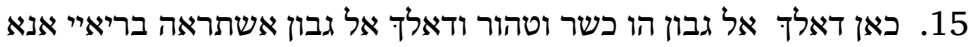

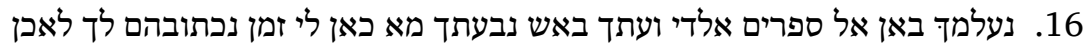


17. מן דאלף אלדי ועת[ך] מוסרע יגיאוף וסלם מן גהתי כתיר לשלום ה"ר אברהם

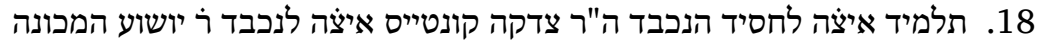
ושלום

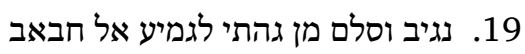
20. מהיי לאמרך יצחק בית עטאי לגמי ועל

\section{Verso}

3
3.
3.

\section{Arabic Transcription}

\section{Recto}

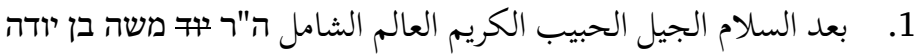

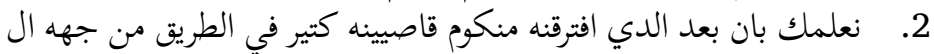

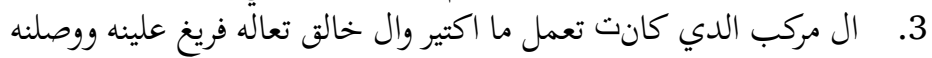

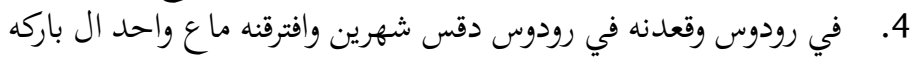

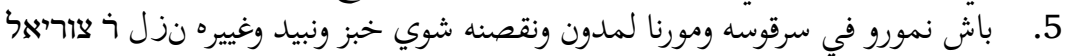

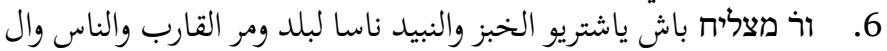

$$
\begin{aligned}
& \text { 7. } \\
& \text { 8. }
\end{aligned}
$$

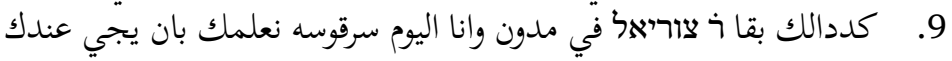

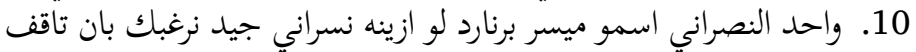

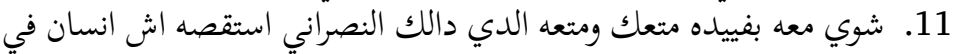

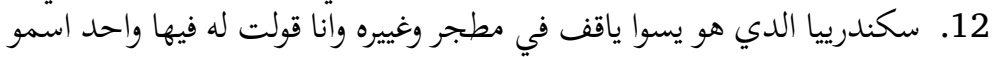

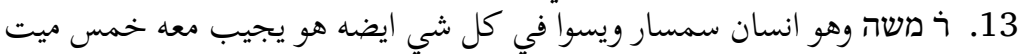

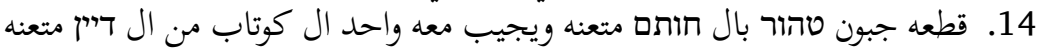

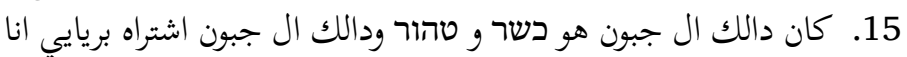

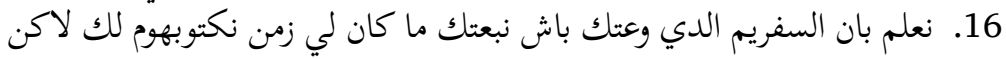

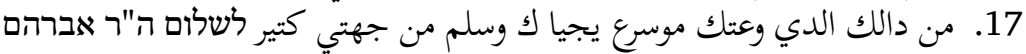

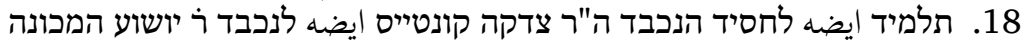

$$
\begin{aligned}
& \text { ושלום }
\end{aligned}
$$

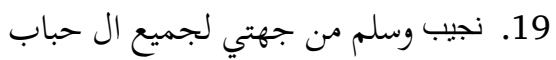


20. مهيي لامرك יצחק בית עטאן

Verso

3.
4.
3.

\section{Translation}

\section{Recto}

(1) After greetings to the dear, the beloved, the honourable, the one of comprehensive knowledge, the honourable rabbi Moses $b$. Judah (2) we inform you that after we separated from you, we travelled for a very long time because of the (3) ship which could not do much better, but the Creator, may he be exalted, showed us the way out and we arrived (4) in Rhodes and stayed in Rhodes Daqas[?] for two months. We departed with a barca (5) in order to go to Syracuse, and went to Modon. We were lacking bread and wine, and other (things). Rabbi Șuriel and (6) Rabbi Maṣliah went down (from the ship) in order to buy bread and wine [from] the country people, and then the (small) boat went off (to the shore), with both the (non-Jewish) people and the (7) Jews on it. Then a pair of ships approached in order to seize our ship. (8) They revealed themselves, and (when) we saw this, we cut the hawser and fled, while the Jews remained in Modon. (9) So Șuriel remained in Modon and I am now in Syracuse. I inform you that (10) one of the Catalan Christians will come to you, his name is Messer Bernard Lo Azina. He is a nice Christian. I want you to 
support (11) him somewhat, for your and his benefit: this Christian inquired about someone in (12) Alexandria who is (his) equal, to support (him) in the market place, and in other things. I told him: there is someone in (Alexandria), his name is (13) Rabbi Moses. He is an agent and equal (to you) in every regard. Also, he will bring with him 500 (14) pieces of kosher cheese with our seal, and he will bring with him a letter from the Dayyan (Jewish judge), (15) also (certifying) that this cheese is indeed kosher and pure. He bought this cheese under my advice. (16) I inform you that the books which I promised you to buy for youI did not have time to write them for you, but (17) those which I promised to you-I am making haste so that they will arrive at yours (soon). Relay from me many greetings to Rabbi Abraham (18) Talmid, and also to the honourable hasid Ședaqah Contias (?), and also to the honourable Joshua known as (19) Najīb, and greet for me all the loved ones. And shalom. (20) Ready for your command, Isaac Bayt 'Aț̣ān.

\section{Verso}

(1) for the beloved, the pleasant, the honourable (2) the lovely, you man greatly beloved ${ }^{1}$ (3) the honourable Rabbi Moses b. Judah (4) from Syracuse to Alexandria.

\section{Commentary}

In some Judaeo-Arabic letters from the 15th century we start to see features that later regularly occur in Judaeo-Arabic Ottoman letters, such as plene spelling of short vowels; the shortening of

${ }^{1}$ Dan. 10.11 . 
long final [a] and subsequent spelling with ה; reflections of the raising of [a] vowels and other dialectal vocalisms; tafkim (velarisation) and tarqi $q$ (de-velarisation) of consonants; non-standard personal pronouns and suffixes; the common occurrence of biimperfect forms and inclusion of vernacular vocabulary.

\section{Recto}

\section{Line 2}

'we separated'. Classical Arabic long final $\bar{a}$ is spelled with throughout the letter.

\section{Line 4}

'Daqas' (דקס). The meaning of this word is not clear, but it appears here to be the name of a locality.

'barca'. A kind of a small boat (in Spanish and Italian).

\section{Line 5}

באש. The word baš is used throughout this letter as the connective 'so that', which points to the Moroccan background of the writer; see Wagner (2014, 148-49).

Line 6

יאשתריו 'they buy' probably reflects dialectal North African morphology of III-y verbs, according to which the final radical is treated like a strong consonant. See also ובקיו 'they stayed' in line 8.

\section{Line 10}

Tarqiq of [ș] in נסראני 'Christian', although earlier in the line it is spelled in its CA form. 
Line 11

reflects the North African form ash, for CA aysh.

Line 12

Tafkim of [t] in מטגר 'market place'. 


\title{
2. THE PURIM SCROLL OF THE CAIRENE JEWISH COMMUNITY
}

\author{
Benjamin Hary
}

The Purim Scroll of the Cairene Jewish Community (megillat pūrim il-mișriyyinn) was probably composed by the spiritual leader of the Jewish community in Cairo, Rabbi Samuel (or Solomon) Sidilio. The Scroll records events following the deliverance of the Jews from the tyrannical rule of Ahmad Pasha, self-appointed governor in Ottoman Egypt in 1524. The community established the 27th of Adar as a day of fasting and the 28th of Adar as a festive holiday to be celebrated after the manner of Purim. On that day the Scroll was read in the local synagogues. There are two versions of the Scroll among the Cairene Jewish community. One is more detailed, mentions names of people and places, and exists in both Hebrew and Egyptian Judaeo-Arabic. The other is shorter, more general, and has survived only in Hebrew. Both versions are critically edited using several manuscripts, translated, and linguistically analysed in Hary (1992).

\section{Transcription}

Adler, Folio 4b 
13. געלוה סולטאן עליהום ונאדו פי

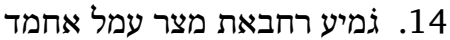
15. באשה סולטאן עלא מצר ועלא גמיע 16. קראהא. ולמא עמל סולטאן 17. גדד אל טולם עלא אל נאס אלדי

\section{Adler, Folio 5a}

$$
\begin{aligned}
& \text { 1. } \\
& \text { 2. } \\
& \text { 3. } \\
& \text { 4. מחל אן סמעו אן אחמד באשה ובלד } \\
& \text { 5. } \\
& \text { 6. } \\
& \text { 7. } \\
& \text { 8. }
\end{aligned}
$$

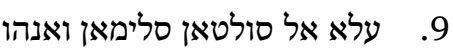

$$
\begin{aligned}
& \text { 10. עמל סולטאן פי מצר } \\
& \text { 11. פחוזנו חוזנן שדידן ועטים } \\
& \text { 12. גדא. ולאפו ذופן עטים }
\end{aligned}
$$

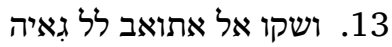

$$
\begin{aligned}
& \text { 14. ואיצא גמיע אהל אל מדינה ذאפו } \\
& \text { 15. ذופן עטים. ושקו תיאבהום }
\end{aligned}
$$

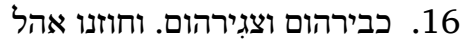

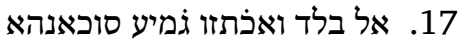

\section{Arabic Transcription}

\section{Adler, Folio 4b}

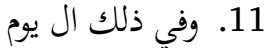

$$
\begin{aligned}
& \text { 12. وقت طلوع احمد باشه لل قلعه }
\end{aligned}
$$

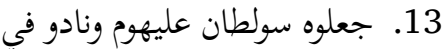

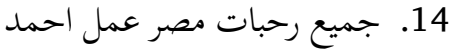

$$
\begin{aligned}
& \text { 15. باشه سولطان علا مصر وعلا جميع احمد عمديع }
\end{aligned}
$$




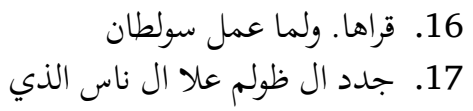

\section{Adler, Folio 5a}

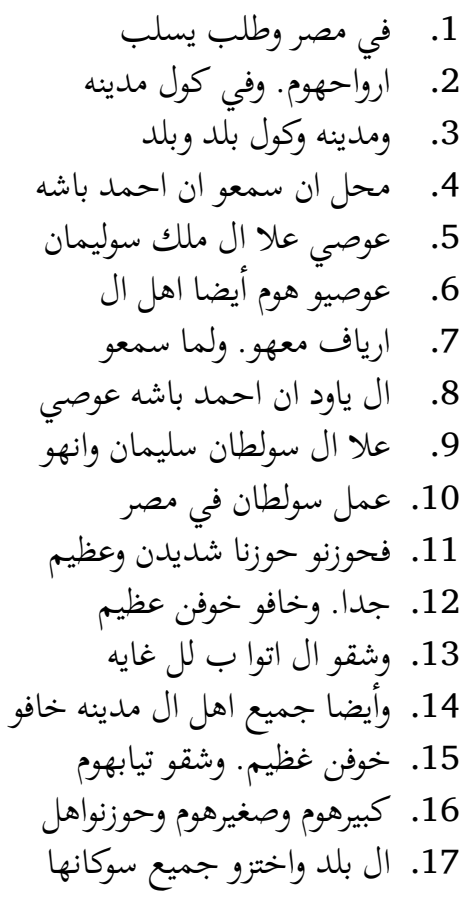

\section{Translation}

(4b) On that day when Ahmad Pasha went up to the Citadel, they appointed him Sultan and (subsequently) people proclaimed in all the squares of Cairo that Ahmad Pasha had become the Sultan of Egypt and all of its towns. When (Ahmad) became the Sultan, he renewed the oppression over the people in Cairo, (5a) seeking to rob them of their wealth. In every district and town, whenever it was heard that Ahmad Pasha had rebelled against King Suleiman, the people of the countryside also rebelled with him. When 
the Jews heard that the Pasha had rebelled against Sultan Suleiman and that he had become the Sultan in Egypt, they grieved tremendously, became very fearful, and tore their clothes into pieces. ${ }^{1}$ Furthermore, all the residents of the city became anxious, too, and both the young as well as the old tore their clothes. The townspeople became sorrowful and all of its dwellers became humiliated.

\section{Commentary}

\section{Folio 4b}

\section{Line 11}

אל יום The separation of the definite article from its following noun and its manifestation as a separate written morpheme is common in Late Judaeo-Arabic (Khan 1991, 225; Hary 2009, 110-11).

\section{Line 12}

טלוע /tuluc/ reflects the preference in Egyptian Judaeo-Arabic for the vowel /u/ (Rosenbuam 2002, 37; Hary 2017, 16-17, 20-21) and the pattern / $\mathrm{fu}^{\mathrm{C}} \mathrm{ul} /$, which is widespread in Egyptian JudaeoArabic (equivalent to standard Egyptian Arabic /ficil/; Hary 2009, 117-18). For the pattern /fu'ul/ see also עוציו (line 5); (line 6); חוזנו (lines 11, 16).

\section{Line 13}

\footnotetext{
${ }^{1}$ Literally: 'they tore their clothes very much'. As is well known, the tearing of clothes is a sign of mourning in the Jewish tradition.
} 
סולטאן reflects the (almost) obligatory spelling of short /u/ with a waw in the Hebraised orthography in Late Egyptian JudaeoArabic (Hary 2017, 16-17).

Line 15

reflects the Hebraised orthography (Hary 1996) where the 'alif maqșūra bi-șūrati $l-y \bar{a}$ ' is not spelled with a yod (as is more common in the Arabicised orthography in Classical Judaeo-Arabic); rather it is spelled with an 'alef here, perhaps due to Aramaic influence (Hary 1992, 252-53).

Line 17

reflects the frozen form of the relative pronoun in Late Judaeo-Arabic (Hary 1992, 308).

\section{Folio 5a}

Line 8

reflects scribes' avoidance of the combination יהו יאוד for its perceived sacred significance (Blanc 1985, 306; Hary 1992, 90, 270).

\section{Line 11}

חוזנן שדידן and also כופן in lines 12 and 15 reflect the spelling of the tanwin accusative in Late Judaeo-Arabic (when is appears in the texts) with a final nun, rather than final 'alef, as is more common in the Arabicised orthography of Classical Judaeo-Arabic (Khan 1991; Hary 1992, 296-98). 



\section{APPOINTMENT DEED OF A CANTOR IN THE KARAITE COMMUNITY, CAIRO \\ (1575)}

Dotan Arad

\section{Transcription}

MS St. Petersburg, Evr. Ar. II $1378^{1}$

It seems that the document is torn and its end is missing. On the verso there is an appointment deed for the same cantor in Hebrew, but its wording is different.

1.

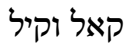
2. כאן חזן כביר 3. ומשרת פי כנסת בית שמחה ומלמד נו'ע'5 והם לא אהלא' לדלך ולא ירצ'א אחד בהם ואלדי (משרת כינס

${ }^{1}$ Published with Hebrew translation in Arad (2016).

2 = בתאריך.

$3=$ = יהפכהו אלהים לטובה.

4 = אלמרחום כבוד ר.

5 = נוחו עדן. 
4. ביחב דלך ומתעצב ענאדה לקול אד' הנ' הג'6 אהרן יצ"ו וכ'ר'7 יוסף אלתוריזי יצ"ו

אלדינים תם אן אלדיינים 5. אלמד' אע'8 אשארו במא ראוה בעין אליראה ואכ'תארו ר' יהודה אלתוריזי הרופא

יצ"ו יכון חזן כביר

6. לאנה נעים קול ומבין בכל ענין ואנה יכון משרת פי בית הכנסת לאנה אהלא' לדלך

ואנה

7. יכדם תלת סנין בלא ג'אמכיה ואנה יסמע לקול אלדיינים אלמד' אע' ולא יכאלפה פי

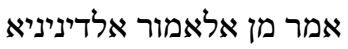

8. ואנה יקים בואג'באת כדמת בית הכנסת כמא כאנו אלמשרתים אלדי כאנו קבלה

ואנה יקים

9. בואג'באת אלחזון שמחות חופות ומילות ואבילות ואנה לא יתכלף ען פעל שי מן דלך

לא לכביר

10. ולא לצג'יר ואנה יתואצ'ע מע אלקהל ויתנהג עמם בטוב לב וידרוש שלום הקהל

גדולם וקטנם

11. ואנה לא יתקלק9 מן דלך ולא יקול אנא באעמל בלא ג'אמכיה מא לאחד עליא חכם

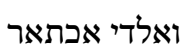

12. אפעלה ואלדי מא אכתארה מא אפעלה ואנה יכדם עדוה וצאחבה פי הנא ועזא

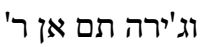

13. יהודה אלתוריזי אחצ'רוה וסמע ג'מיע מא כתב עליה אע' תם אנה רצ'י בג'מיע מא

דכר אע' יהודה אלית

14. וקבלה עליה כמא דכר אע' טואל אלמדה אלמד' אע' תם בעד דלך חתמו אלדינים

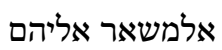

15. באן לא סביל לאחד מן אלקהל בר' יה'10' יתקדם עליה ולא יבתדלה [ל]אנה מא

ביעמל דלך [אלא לשם]

16. שמים ואן לא סביל לאחד יעאנדה ול[...] [ג] מיע מא פעל וכל דל[ד] חצל ברצ'אהם

${ }^{6}=$ אדוננו הנשיא הגדול.

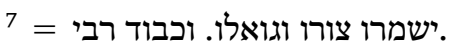

8 = אלמדכורין אעלאה. See Wehr (1994, 749), مذكور اعلרורי.

${ }^{9}$ Should probably be: יתקלקל

$10=$ ברוכים יהיו. 


\section{Arabic Transcription}

1. لما كان بتا' نهار الاثنين כ"ח شهر اب יא"ל سنه ה'ש'ל'ה' ליצירה حصل قال وقيل

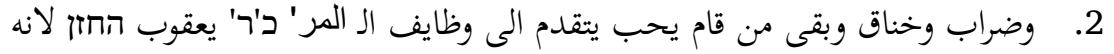
كان חזן كبير

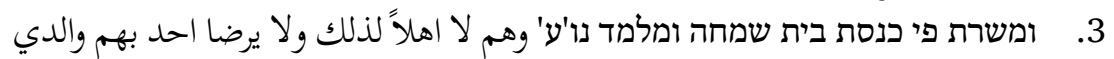
4. بيحب دلك ومتعصب عناده لقول אד' הנ' הג' אהרן יצ"ו וכ'ר' יוסף אלית אלתוריזי יצ" אלדינים ثم ان الדיינים

5. المد' اع' اثارو بما راوه بعين الיראה واختارو ר' יהודה אלתוריזי הרופא יצ"ו يكون חזן كبير 6. لانه נעים קול ומבין בכל ענין وانه يكون משרת في בית הכנסת لانه اهلاً لدلك وانه

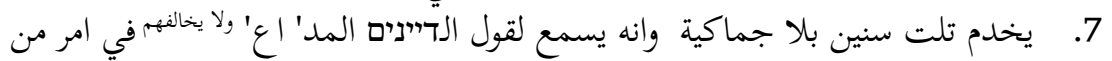
الامور الدينينيا؟ 8. وانه يقيم بواجبات خدمة בית הכנסת كما كانو الמשרתים الدي كانو قبله وانه يقيم

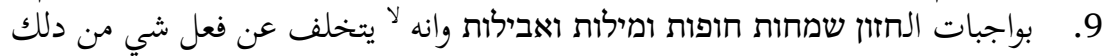
لا لكبير 10. ولا لصغير وانه يتواضع مع الקהל ויתנהג עמם בטוב לב וידרוש שלום הקהל גדולם וקטנם

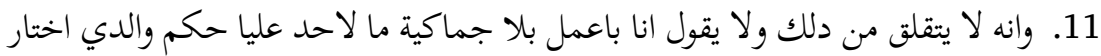

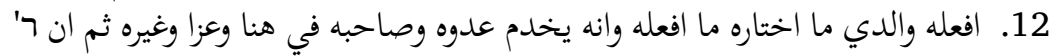

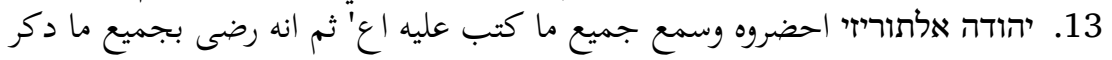

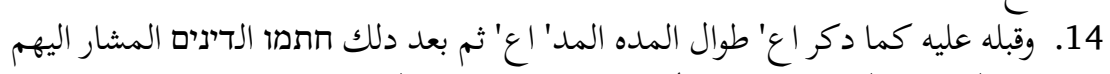

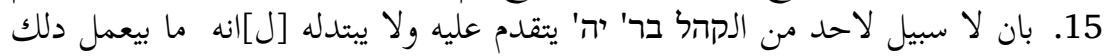
[אלא לשם لע. 16. שמים وان لا سبيل لاحد يعانده ول[ [..] [ج][ميع ما فعل وكل دل[ك] حصل برضاهم

\section{Translation}

With God's help (1) On the date of Monday, 28th of Av, may God turn it for the better, of the year 5335 of the creation $[=1575$ 
$\mathrm{CE}],{ }^{11}$ prattle $^{12}(2)$ and quarrel and dispute had happened. Everyone who wanted to be appointed to the duties of the late, the honourable R. Jacob the cantor, because he was the chief cantor (3) and a beadle in the Bet Simcha synagogue, and a [children's] teacher-may he rest in heaven-was found unsuitable for it. None of them was acceptable. He who (4) wants it stubbornly stood up against our master, our great Exilarch Aaron-may his Rock and Redeemer [=God] protect him-and against the honourable R. Joseph al-Tawrīzī-may his Rock and Redeemer protect him-the judges. Thus, the aforementioned (5) judges ordered, according to what they saw "with the eye of fear [of God]," and chose R. Judah al-Tawrīzì the physician-may his Rock and Redeemer protect him-to be a chief cantor, (6) because he has a pleasant voice and he is expert on every matter; and to be a beadle of the synagogue, because he is suitable for it. He will (7) serve 3 years without salary; ${ }^{13}$ and should obey the aforementioned judges' orders; and he should not disobey them in any religious matter. (8) He should fulfil the duties of the synagogue's service, as the former beadles have done; and he should fulfil (9) the duties of the cantorship in weddings, circumcision

${ }^{11}$ According to the Rabbanite calendar, 28th of Av 5335 occurred on Thursday, 14 August 1575. The Karaite calendar was not predetermined in that period. The date of the deed could be, therefore, one of the close Mondays to the Rabbanite date (11.8.1575 or 18.7.1575) or even a month later, if the Karaites added one month to the Hebrew Calendar that year.

${ }^{12}$ See Wehr (1994, 933): قال وقيل / قيل وقال 'long palaver; idle talk, prattle, gossip’. See also Kazimirski $(1860,837)$ قال وقال وقال

${ }^{13}$ See Kazimirski $(1860,329)$. 
celebrations, and mourning ceremonies, and should not be negligent $^{14}$ in doing any of it, in neither large nor (10) small matters. He should behave humbly with the congregation and relate to them with good heart, and greet the congregation, their old and their young (11), and not do it lazily. ${ }^{15}$ He should not say: "I am working without salary, nobody has a claim on me, and I will do (12) only what I choose"; and he should serve his friend as well as his enemy, in greetings and condolences and the like. Then R. (13) Judah al-Tawrīzi was brought, ${ }^{16}$ and heard all of what is written about him above, and he agreed with all that was mentioned above (14) and accepted it for himself, according to what is mentioned above for the aforementioned period. After that, the aforementioned judges assigned (15) that it is not possible ${ }^{17}$ for any of the congregation (members) - may they be blessed-to be appointed instead of him, nor to replace him, ${ }^{18}$ because he is doing it only "in the name (16) of heaven" [ = with pure intentions], and there is no option for any to object to him with obstinacy. And $[\ldots]$ everything that was done. All of that happened of their [free] will...

\footnotetext{
${ }^{14}$ See Blau (2004, 193), خلف.

${ }^{15}$ See Hinds and Badawi (1986, 715), تقلقل.

${ }^{16}$ Before the judges.

${ }^{17}$ See Wehr (1994, 461), سبيل; Friedman (2016, 558), כאן לה סביל.

${ }^{18}$ I have not found the eighth form of the root بدل in the dictionaries. This is perhaps a scribal error for what should read יתבדלה. Blau (2004, 36) attests to the existence of بدل in the eighth form, translating 'to profane', but this meaning is not appropriate here.
} 


\section{Commentary}

Line 2

ובקי. Used as auxiliary verb; see Blau (2006, 47); Friedman (2016, 60).

Line 4

ביחב. Bi-imperfect 'he wants'. 


\title{
4. AHARON GARISH, METSAH AHARON
}

\author{
Nahem Ilan
}

A commentary on Deuteronomy, MS London Or. 10704 (Gaster Collection 930), fols. 97a-99b:

\section{Transcription}

וקולה פין (!) יש בכם איש או אשה או משפחה או שבט אשר לבבו פונה היום מעים (!)

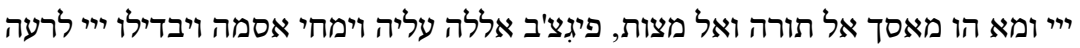

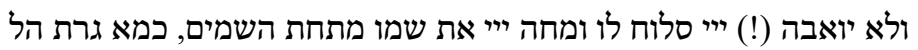
מעשה גרא פי ואחד ואסמה שמואל, וכאן חכם עצ'ים, וזאל פיה אלקצא ונשתמד, וצאר ערל, ועבר פי דת אל ערילים, וערף פי דת אלדי להום, וצאר אויב

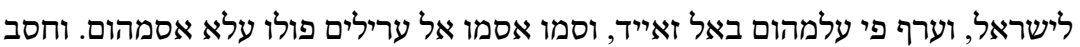
פי באלו אן יפני ג'מעיית ישראל בר מנן, וגזר עלא ישראל אן יפניהום ולא יכלי בר מנן להום (97ב) אתר. פראח לענד אל צולטאן אל ערילים וקאל לה: האדול אל יהוד עד[...] לנא, ופי צלאה אלדי להום, ביודעו עלינא, ובירידו לנא אל וחיש, והום אעדא אל כובאר

לנא, אסמע מני ואפניהום מן אל דוניא. ואלדי ידכול לדיינא נסתבקי להום אתר, ואן ידכול לדיינא נבקיה. פג'אובו אל אל (!) צולטאן וקאל לה: באיי חוג'ה נג'י עליהום חתא

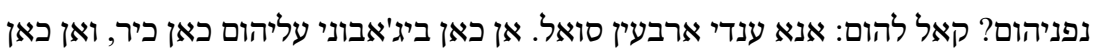
מא ביג'אובוני עליהום, ואלא אפניהום ג'מיעהום ג'ומלת אן ואחדה.

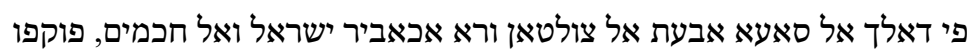
קודאם אל צולטאן ואל דיואן ואל וזרא ואל אומרא. פוקף דאלך אל משומד אל רשע אל סאלאות

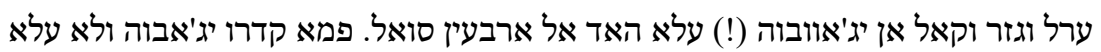

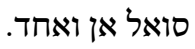


פבכיו ג'מעית ישראל בכא אן שדיד, וקאלו: יא מולאנא אל סולטאן, בנטלוב מנך רחמה, ותרחמנא אנך תעטינא מוהלת ארבעין יום עלא קדר ארבעין סואל אלדי ביריד יסאלנא האדא אל רג'ול. פחט אללה סוֹ פי קלבה אל רחמה, ואעטאהום מוהלת ארבעין

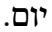

פג'ו לבית (98א) הכנסת וצלו ואתחננו קודאם אללה סו וגזרו תענית פי אל צבור, ובעתו רוסלא לג'מיע אל מודן אלדי קריבין אליהום, אנהו יצומו ויתחננו קודאם אללה סו. תם אנה ואחד מן אל רוסלא ראח וג'אב מודת עשרין יום. והו פי אל עשרין יום, ואלא צאדף רג'ול שיך וכביר ומחתרם. סאל לדאלך אל רגול וקאל לה: איש לך חאגה פי האד אל בלד? קאל לה: יא סידי, ענדך תעלם אן אל יהודים פי שודה עצ'ימה, ואכדו מוהלה מן אל סולטאן ארבעין יום, ומצ'ת מנהא עשרים יום, בקא עשרין יום אאכר, ובר

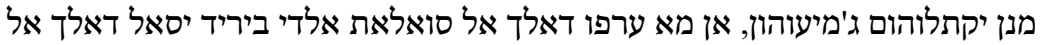
רשע לל יהוד. ג'אובו דאלך אל שיך וקאל לה: לא תכאף, אגלוס ענדי, ומא יציר לכום אלא אל כיר ואל סלאמה. פאגצבן וקעד ענדה מודת יח יום, בקי עליה יומין מן אל עשרין.

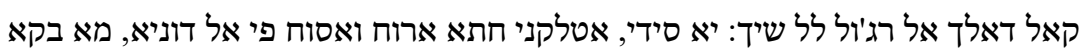
לי צבר אני אקעוד הל יומין. קאל לה: יא ולדי, טוול רוחך וכון מסתעקד באללה סוֹ, באנה

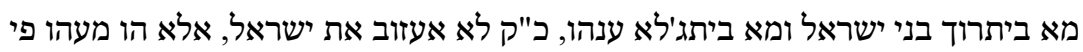
כול שדה, כ"ק עמו אנכי בצרה.

אל שיך כאן ענדה (98ב) ברכה מלאנה מייה. קאל לה: קום אל יום חתא נצלי בעריה לאללה סוֹ, ונדעיה לגמעיית ישראל אן ינצרהום עלא דאלך אל רשע. פקאמו אתניהום

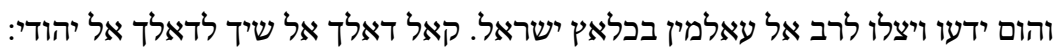
אשלח תיאבך חתא אנזל אנא ואיאך נעמל טבילה פי האד אל ברכה. שלח דאלך אל רג'ול תיאבו, וג'ו מלאכים אכדו אל דאלך אל תיאב ווצלוהום לחמאם מדינת אל יהוד אלדי פיהא דאלך אל גזרה. ונזלו חתא ינטבלו, וטלעו אתניהון פי דאלך אל חמאם. קאל דאלך אל רג'ול לל שיך: יא סידי, נחנא מן גאבנא להאד אל מכאן? קאל לה אל שיך: אסכות ואנצ'ור עגאייב אללה סוֹ.

פלמא וצלו להארת (!) אל יהוד, נצ'רו אל צולאם מאסכין אל יהוד, ועמאלין ביחצ'רוהום לחצ'רת אל סולטאן. קאל להום דאלך אל שיך: אפרגו האדא אל יהוד ואנא אטלע לחצ'רת אל סולטאן ואעטיה ג'ואבאתה. פאכדו דאלך אל שיך וקדמוה לל סולטאן. 
וקאל לל סולטאן ואל חאצ'רין: יג'י האד אל רגול ויסאלני. אין רדת סואלתה (!)

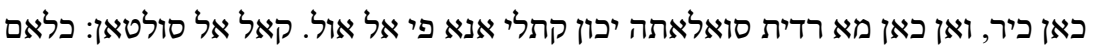

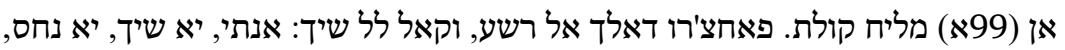
אנת תקדר תרוד לי גואבאתי? קאל לה: יא רשע, אנא בקדרת אלהים אלהי ישראל סוֹ, באקדר ארוד לך ג'ואבאתך. לאכן אנא באתכלם כלמה באגאזת אל סולטאן ואל חאצ'רין, ואנא כדאלך ענדי בעץ' סואלאת. אן מא רדתהון, יכון דמך חלאל, אני אקתלך. קאל דאלך אל רשע: נעם, והכדא יציר.

פקאם דאלך אל רשע עלא חילה וסאל אל ארבעין סואל, ורדהם דאלך אל שיך ג'מיעהום, וצאר ישראל יכלצו באל סלאמה. קאל דאלך אל שיך: יא מולאנא אל סולטאן, ואנא באריד אן ירוד סואלי. פסאלה אול סואל ותאני סואל ותאלת סואל ומא קדר יג'אווב (!) ולא ואחד. פאל חין אלתזם דאלך אל רשע אל קתל. קאם דאלך אל שיך

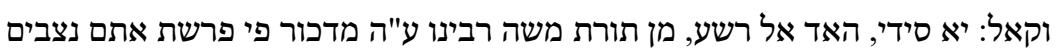
אנה מצירה ינקלב אסמה, ותג'ו אנתו ותסמוה פולו. ונחנא כאן ענדנא אסמו שמואל.

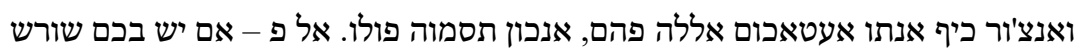

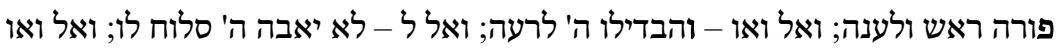
אלאכראנייה - ומחה ה' את שמו מתחת השמים. פי דאלך אל סאעא קאל אל שיך: יא סבע, אטלע וכוד נציבך. פאנשק אל חיט המתות המתום וטלע סבע אן כביר וקתלה, ומא כלא מנה אתר. ודאר אל סבע חתא יפתרס לל סולטאן.

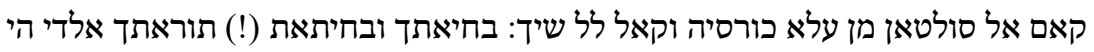

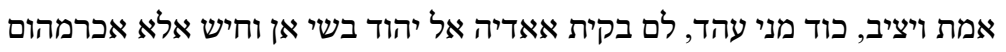

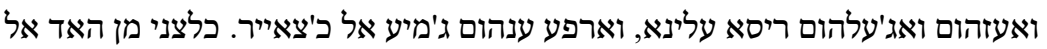

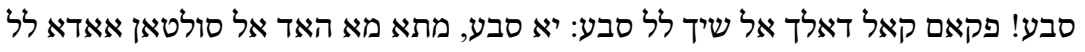

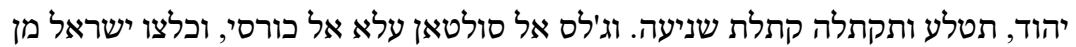
דאלך אל צרה. ומתל מא כלצו ישראל מן יד אל רשע, כדאלך יכלצו ישראל מן כל צרה וצוקה, ויהי ייי אלהים עמנו כאשר היה עם אבותינו, אמן וכן יהי רצון. 


\section{Arabic Transcription}

وقوله פין (!) יש בכם איש או אשה או משפחה או שבט אשר לבבו פונה היום מעים (!) יי" وما هو ماسك ال תורה وال מצות, فيغضب الله عليه ويمحي اسمه اיבדילו (!) ייי לרעה ולא יואבה (!) ייי סלוח לו ומחה ייי את שמו מתחת השמים, كما جرت هل هل מעשה جرى في واحد واسمه שמואל, وكان حكم عظيم, وزال فيه القضاء ונשתמד, وصار ערל, وعبر في דת ال ערילים, وعرف في דת الذي لهوم, وصار אויב לישראל, وعرف

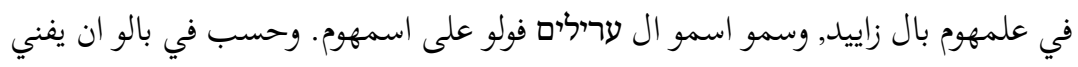
جمعييت ישראל בר מנן, וגזר على ישראל ان يفنيهوم ولا يخلي בר מנر لهوم (19) (197) اتر.

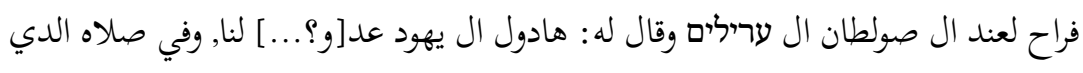

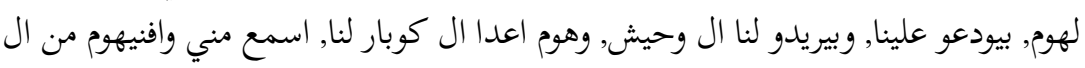

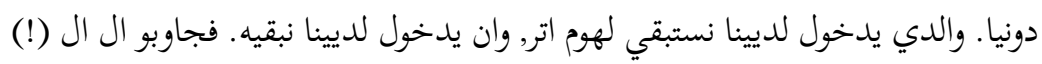

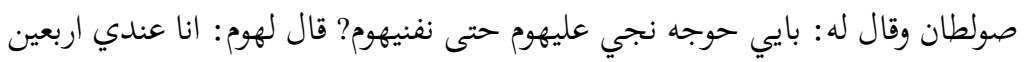

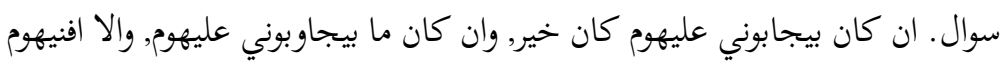
جميعهوم جوملت ان واحده. في دالك ال ساعا ابعت ال صولطان ورا اكابير ישראל وال חכמים, فوقفو قودام ال

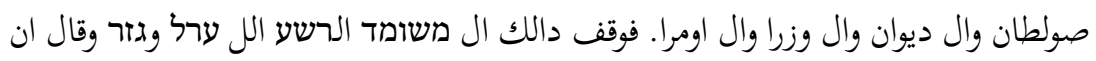

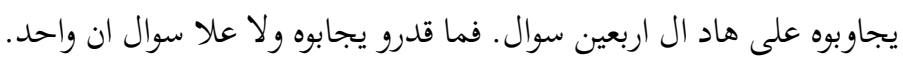

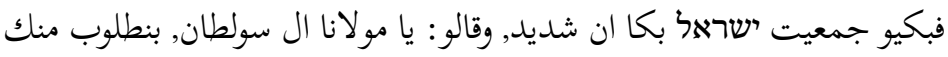
رحمه, وترحمنا انك تعطينا موهلت اربعين يوم على قدر اربعين سوال الدي بيريد يسالنا هادا

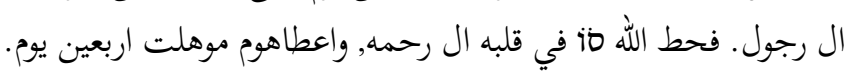

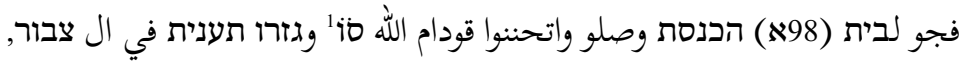
وبعتوا روسلا لجميع ال مودن الدي قريبين اليهوم, انهو يصوموا ويتحننو² قودام الله ما.

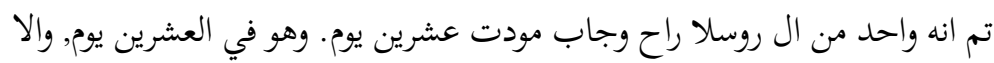

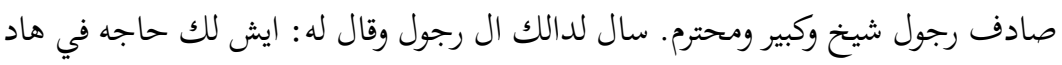

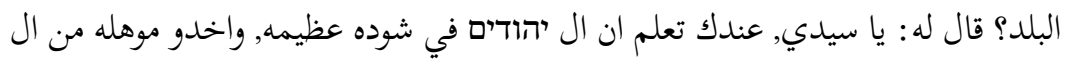

\footnotetext{
1 سبحانه وتعالى
}

${ }^{2}$ This could be a case of borrowing from the Hebrew verb יתחנן 
سولطان اربعين يوم, ومضت منها لاשרים يوم, بقا عشرين يوم اخر , اבר מנر يقتلوهوم

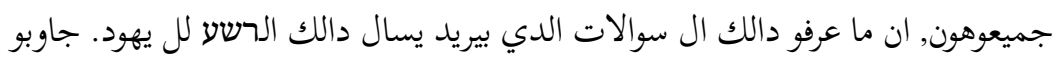

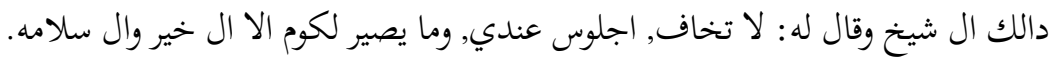

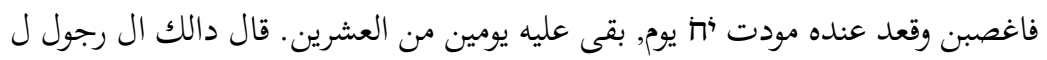

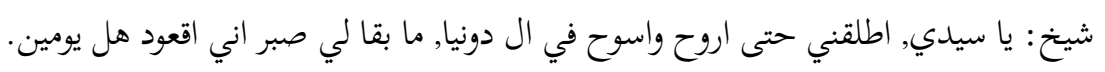

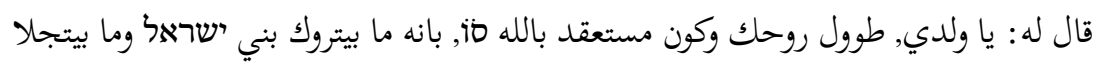

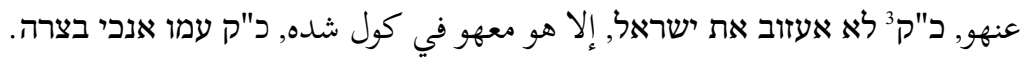

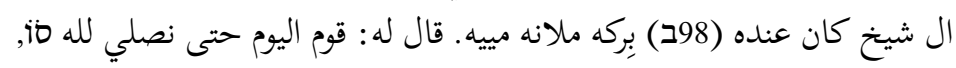

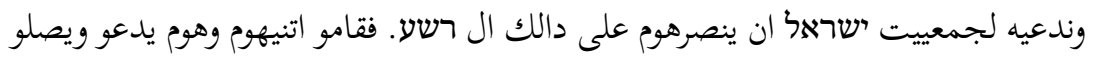
ل كرب ال عالمين بخلاص ישראל.

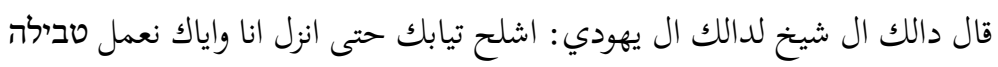

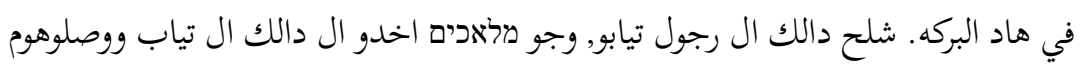

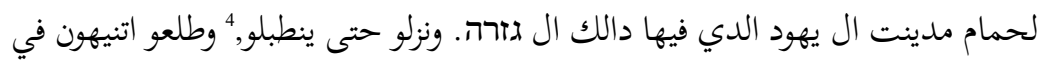

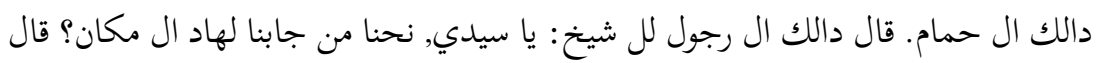
له ال شيخ: اسكوت وانضور عجاييب الله مأ.

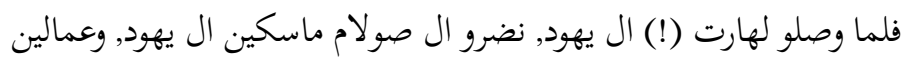

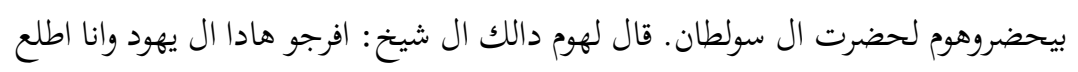

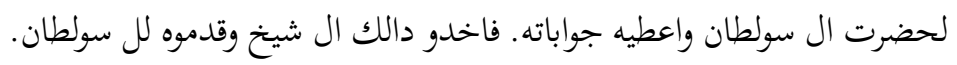

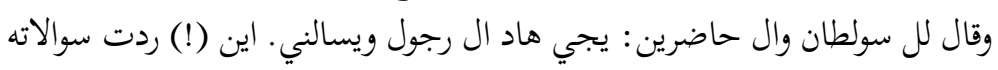

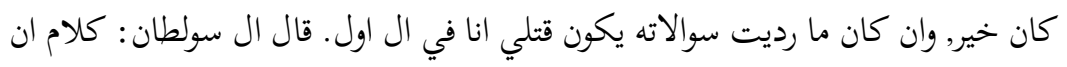

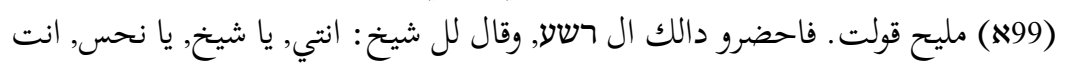

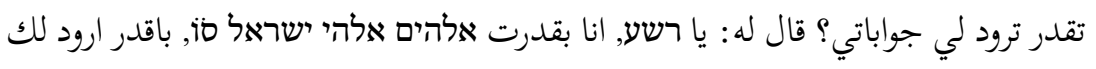

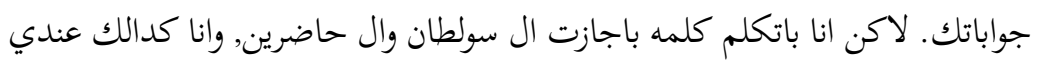

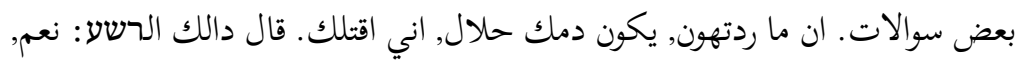
وهكدا يصير.

3 كما قال 3.

${ }^{4}$ Borrowing from the Hebrew verb טבל, means dive in the water, or go under water. 
فقام دالك الحسل على حيله وسال ال اربعين سوال, وردهم دالك ال شيخ

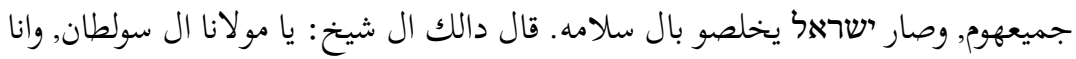

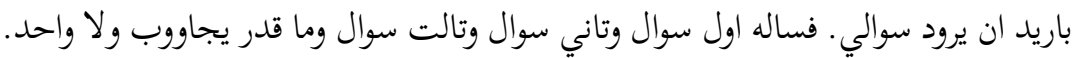

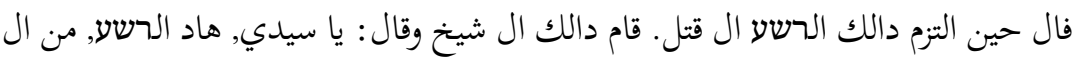
תורת משה רבינו ע"ה مدكور في פרשת אתם נצבים انه مصيره ينقلب اسمه, وتجو انتو

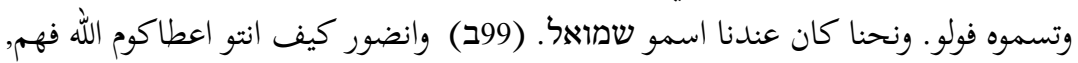

انكون تسموه فولو. ال ف (פ) - אם יש בכם שורש פורה ראש ולענה; وال واو - -

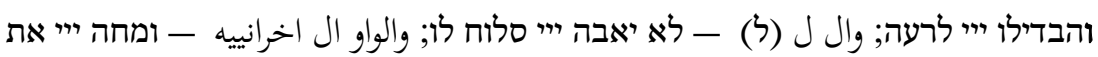
שמו מתחת השמים. في دالك ال ساعا قال ال شيخ: يا سبع, اطلع وخود نصيبك. فانثق ال حيط وطلع

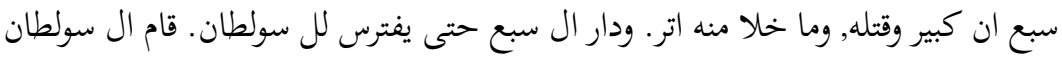

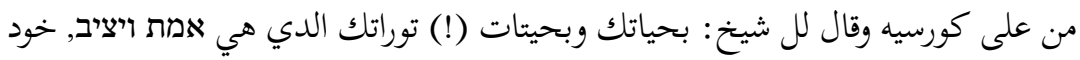

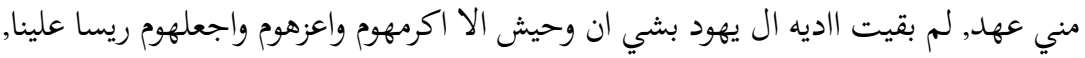

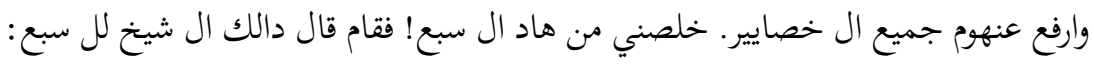

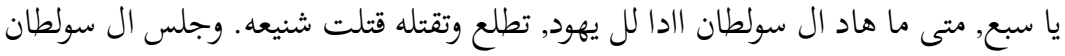
علا ال كورسي, وخلصو ישראל من دالك الكاد سولئ.

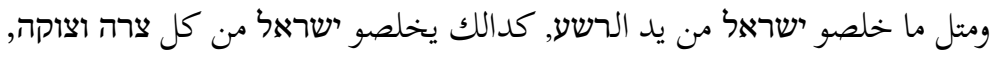
ויהי ייי אלהים (!) עמנו כאשר היה עם אבותינו, אמן וכן יהי רצון.

\section{Translation}

And his saying "lest there should be among you man, or woman, or family, or tribe, whose heart turneth away this day from the Lord" (Deut. 29.17) and he does not take hold of the Torah and the commandments, then the Lord shall be angry at him and shall blot out his name, and the Lord shall separate him unto evil [...] and will not be willing to pardon him [...] and shall blot out his name from under heaven" (Deut. 29.19), just like: 
The story of a person named Shmuel, who was a great scholar, and he converted and became a Christian, and learned their religion, and became an enemy of Israel, and he became an expert in their ideas. The Christians called him Paulo. He thought to diminish the community of Israel-May it not befall us! He decreed to destroy Israel and not leave-May it not befall usany (97b) survivors. So he went to the gentile Sultan and told him: "These Jews are our enemies, and in their prayers they curse us, they only want evil for us, and they are our worst enemies. Listen to me and I shall destroy them from the world. Whoever choses to convert to our religion we shall keep alive." The Sultan answered him: "On what pretext are we going to destroy them?" He told him: "I have forty questions. If they answer them, so be it; and if they don't, I shall surely destroy them all at once."

At that moment the Sultan sent for the Jewish leaders and scholars, and they came before the Sultan, the Prime Minister, ministers, and princes. That evil convert stood there and decreed, and said they needed to answer those forty questions. They could not answer, not even a single question.

The community of Israel wept hard, and said: "Our master the Sultan, we ask you for mercy, please spare us and give us an extension of forty days for the forty questions this man wants to ask us." God almighty put mercy in his heart, and he gave them a forty-day extension.

They came to the (98a) synagogue, and prayed and beseeched God almighty, and decreed a communal fast, and sent messengers to all the nearby towns to fast and pray to God almighty. 
One of these messengers went missing for twenty days. On the twentieth day he saw an honoured, distinguished old man. The old man asked that person: "Do you have any business in this town?" He said: "Sir, you should know that the Jews are in serious trouble, and have received a forty-day extension from the Sultan, twenty of which have already passed. Twenty days are left, and-May it not befall us-they will kill everyone, if they don't know the questions this evil man wants to ask the Jews." The old man answered him: "Don't be afraid. Sit with me, and you will have nothing but good and peace." Against his will he sat with the old man for eighteen days. With two days left out of the twenty, the man told the old man: "Sir, please let me go and I will go wander the world. I have no patience left in me to wait these two days." He told him: "My son, be patient, and believe in God almighty, who will not leave the sons of Israel and will not desert them, as it is said "I will not forsake my people Israel" (1 Kgs 6.13; altered version), but he is with them in all trouble, as it is said "I will be with him in trouble" (Ps. 91.15).

The old man had (98b) a pool full of water. He told him: "Get up today in order we will pray to God almighty, and ask him on behalf of the community of Israel, to help them with that evil man." The two of them rose, and they were calling and praying to the Lord of the World for the redemption of Israel. That old man said to that Jew: "Take off your clothes, so that you and I can get into this pool for ritual immersion." The man took his clothes off, and angels came and took the clothes, and brought the men to the bath in the town of the Jews in danger of the 
decree. They went down for ritual immersion, and the two immersed in that bath. The man said to the old man: "Sir, who brought us to this place?" The old man said to him: "Be quiet and see the greatness of the Lord almighty."

When they got to the Jewish neighbourhood, they saw the evil ones taking the Jews to bring them to the Sultan. The old man told them: "Let these Jews go, and I will come to the Sultan, and give him his answers." They took the old man and brought him to the Sultan.

He said to the Sultan and the others who were present: "Let this man come and ask me. If I answer his questions, good; and if I don't answer his questions, kill me first." The Sultan said: "Well (99a) spoken." They brought the evil man, who said to the old man: "You, worthless old man, you can give me my answers?!" He told him: "Ho, evil one, I-with the power of God almighty, God of Israel—can give you your answers. But I will say something, with the permission of the Sultan and those present. I also have a few questions. If you don't answer them, your blood shall be permitted, and I will kill you." The evil man said: "Yes, and so be it."

That evil rose and asked the forty questions. That old man answered him all of them, and Israel were saved in peace. The old man said: "Our master, the Sultan, I want him to answer my questions." So he asked him a first question, and second and third, and he couldn't answer a single one. He immediately was condemned to death. That old man rose and said: "Sir, that evil man is mentioned in the Torah of Moses-may he rest in peacein the portion of Atem Nitsavim 'Ye stand', and that eventually his 
name will be changed, and you would call him Paulo, and with us his name was Shmuel. See how God has given you wisdom to call him Paulo (פולו):

פ - אם יש בכם שורש פורה ראש ולענה; ו - והבדילו ייי לרעה; ל - לא יאבה ייי סלוח לו; ו - ומחה ייי את שמו מתחת השמים! $\mathrm{P}$ - 'lest there should be among you a root that beareth gall and wormwood' (Deut. 29.17); W - 'And the Lord shall separate him unto evil out' (v. 20); L - 'The Lord will not spare him' (v. 19); W - 'and the Lord shall blot out his name from under heaven' (v. 19).

At that moment the old man said: "Lion, go out and take your share!" The wall broke open and a big lion came out, who killed him and left no remains. The lion turned around to kill the Sultan. The Sultan rose off his throne and told the old man: "By your life and the life of your Torah, which is true, take a promise from me that I will do nothing evil to the Jews, only respect and glorify them, and make them chiefs over us, and remove all troubles from them. Save me from that lion!" The old man rose and told the lion: "Ho, Lion, when this Sultan is ill-favoured toward the Jews, come out and kill him in a shameful death." The Sultan sat on his throne and Israel were saved from that trouble.

And as Israel were saved from that evil, they shall be saved from any trouble and calamity, "and may God be with us, like he was with our fathers" (1 Kgs 8.57). Amen. 


\section{Commentary}

The story brought here is unusual in two dimensions: it is the only folk story mentioned in Metsah Aharon, and it reflects a cultural setting that was foreign to Aleppo Jewry in the early 16th century. However, it fits well with Rabbi Aharon Garish's cultural background. The commentary was based mostly on Midrashim and early Agadot, Torah commentaries (Rabbenu Hananel, Rabbi Avraham Ibn Ezra, Hizkuni, Nahmanides, Bahya ben Asher, Rabbi Yaacov ben Asher [Bacal Ha-Turim], the Tosafotists), Rabbi Yehoshua Ibn Shu'ayb's sermons, Maimonides (Mishne Torah and The Guide for the Perplexed), and Arba'a Turim-Orah Hayyim. Therefore, his cultural world was a blend of the best of Europe's composition-Spain, Provence, France, and Ashkenaz.

The background for this story is the public polemics that took place between churchmen, particularly converts, and Jewish leaders in Spain and France, especially during the 13th-14th centuries, which was unknown to the Muslim Orient. While strange to the Aleppo lifestyle, it shows that the thrilling plot, the eventual miraculous resolution, and anchoring the story in Torah verses were enough to include it in the commentary. It is a reflection of the commentator's (or his ancestors') cultural world, a heritage passed on from generation to generation, dearly cherished.

Various considerations (literary, linguistic, stylistic, and educational) suggest that it started as an oral sermon given by 
Rabbi Aharon on Shabbat Nitsavim, which later resulted in it being included in the written commentary. ${ }^{5}$

${ }^{5}$ This story is found in a shorter version in Havlin (1995, 176-177), and the arena there is Provence, probably the 12th Century. See also Ilan (1996, esp. 181-184, 207-210). 


\title{
5. KITĀB HAZZ AL-QUḤŪF (1600S) ${ }^{1}$
}

\author{
Humphrey Taman Davies
}

Al-Shirbīnī's work, which he probably wrote in or soon after 1686, is perhaps unique in pre-20th-century Arabic literature, and unusual in any pre-20th-century scholarly literature, in focusing on the countryside as a cultural, social, economic, and religious site in its own right. The work, which is in two parts, surveys, in the first, the three estates of rural (effectively, northeastern Egyptian Delta) society: the peasant (and above all the poor peasant) as cultivator or fallāh; the country pastor or faqih; and the mendicant rural Sufi or faqiir. A further section analyses and mocks bad verse written by peasants and other marginal figures (e.g., a Mamluk emir of Ethiopian origin). The second part of the work analyses at length and with numerous digressions a forty-seven-line poem, supposedly written by a peasant called Abū Shādūf. The poem describes its supposed author's rise and fall, evolves into an extended lament for the delicious foods that, in his decline, the poet can only dream of eating, and ends with the poet's describing his project to restore his fortunes by going to the city and stealing slippers from outside a mosque. The book winds up with a miscellany of anecdotes, mostly about grammarians.

${ }^{1}$ Reprinted from Davies (ed.) (2016, I:65-78, 122-27, 129-31). 
The thrust of the argument throughout the book is that country people are coarse (kathif) and their natures cannot be changed; they contrast in all things with the city dweller, who is refined (latiff). Coarseness in this context includes physical grossness, moral turpitude, and ignorance. Of particular concern to the author are the false claims to knowledge made by 'people of the countryside'; in a number of scenes, Azhari scholars are challenged to a battle of wits by a village man of religion, the hollowness of whose learning is exposed and ridiculed by his opponents.

There is evidence that, against the conventional notion of cultural decline, literacy increased during the Ottoman period, in part because of the spread of the kuttāb, a school in which young children memorised the Qur’ān and achieved basic literacy and numeracy. As a result, as Nelly Hanna (1998, 102-3) writes, "many more people knew how to read and write beyond those who were attached to institutions of higher education" and literacy spread, especially among artisans and tradesmen. It is possible that the traditional gatekeepers of learning became alarmed by this process and that the author, of whose career little is known beyond his having been at some point a bookseller, was commissioned to write Brains Confounded to undermine claims to knowledge by the non-scholarly non-elite. According to this interpretation, then, the 'people of the countryside' are but standins for the great unwashed in general, and for those who threatened the scholarly hegemony over knowledge in particular.

The comic impact of Brains Confounded depends on two conceits. The first is that the Ode and other verses ascribed by 
the author to peasants are indeed of rural origin and represent actual rural literary production. This is obviously untrue, and we assume that such verses were manufactured by al-Shirbīni or others of his milieu to be the butt of their satire. The discovery of a short work dating to some forty years before Brains Confounded and containing some of the same poems satirised by al-Shirbīni offers an intriguing hint that such writings may have been in fashion in the second half of the 17th century.

The second conceit is that such verse merits the deployment of the tools of etymological, grammatical, rhetorical, and historical analysis developed by Arab philologists for the elucidation of the fundamental texts of their culture, such as the Qur'ān and classical verse, even while the author is at pains to stress that the material that is the object of these critical attentions is innately ridiculous and unworthy of consideration as literature by virtue both of its 'rural' language and the low social status, and concomitant vices, of its creators.

Taken as a whole, al-Shirbīnī's work provides an example of Arabic comic writing at its best, its arguments at base serious, its techniques inventive, its energy never flagging. It also provides, in its multiple digressions into subjects as diverse as fleas and farting, an intriguing window into the mind, or perhaps the mental lumber room, of an educated man of the mid-Ottoman period in Egypt.

The first two excerpts are from a passage in the first part of the work entitled 'Accounts of What Happened to Peasants Who Went to the City'. They exemplify the presentation of the peasant as irredeemably gross, both physically and morally, and touch on 
a number of frequently recurring themes: the peasant's trip to the city (Cairo) to pay taxes to his 'master' (the local tax-farmer, usually a Mamluk), such trips inevitably leading to misadventure; Turkish as a shibboleth of the elite; and the peasants' terror of forced labor. The second set of excerpts focuses on the pretensions to knowledge of the rural faqih 'country pastor', and his actual ludicrous ignorance, which render him easy prey for the 'well-instructed'.

\section{Transcription}

\subsection{2}

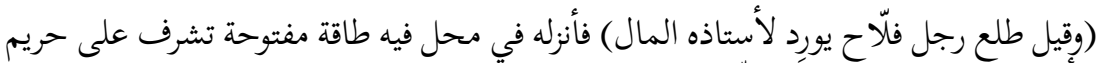

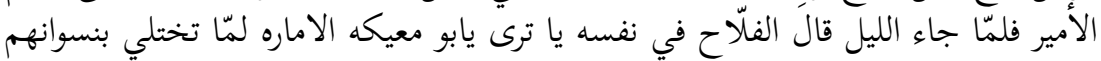

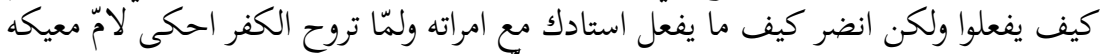

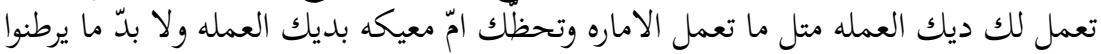

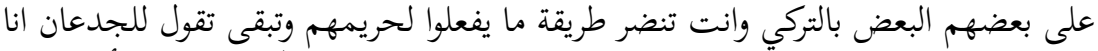

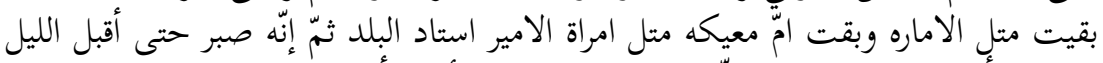

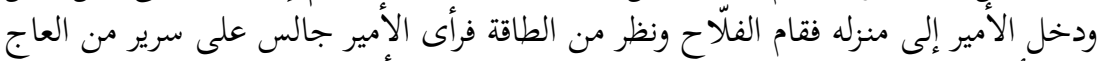

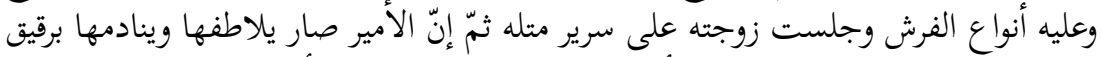

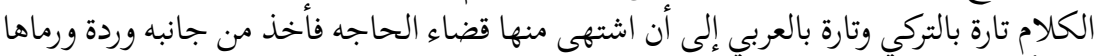

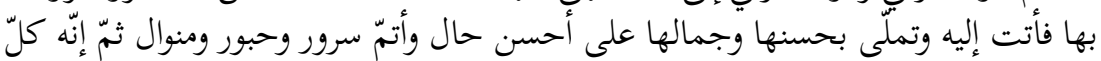
واحد منهما انضجع على سريره ونام

\subsection{3}

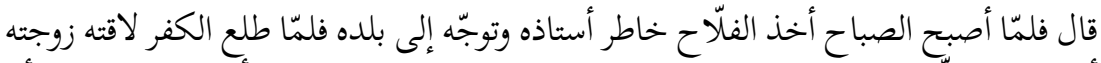

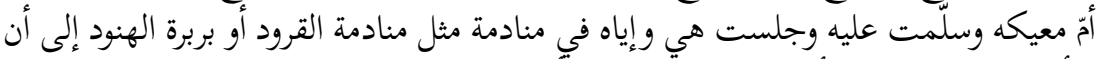

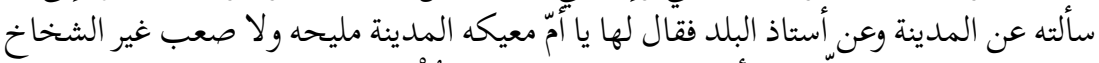

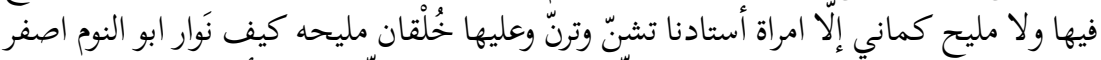

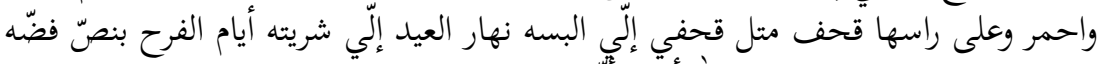

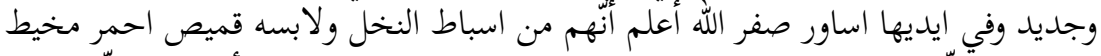

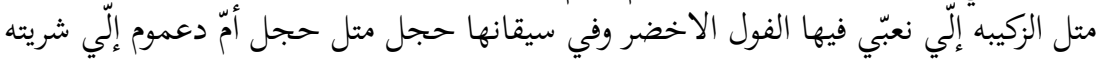




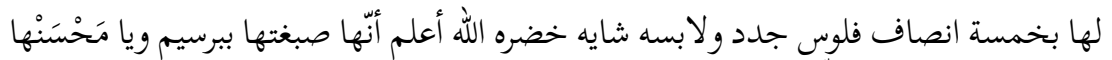

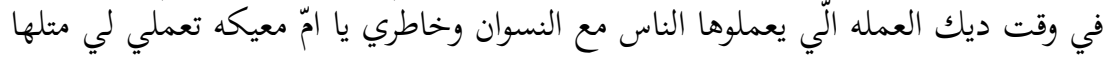

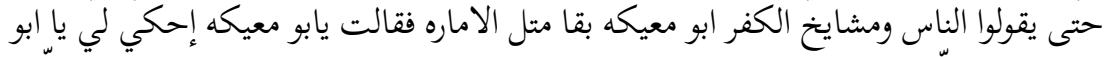

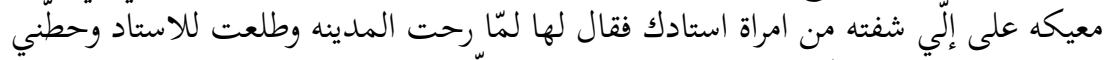

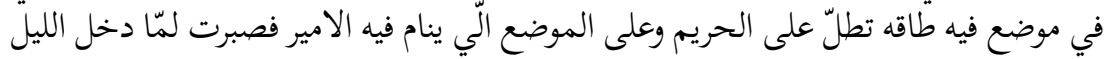

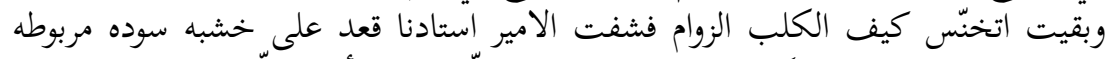

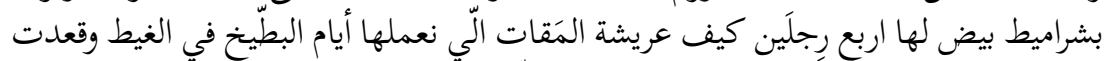

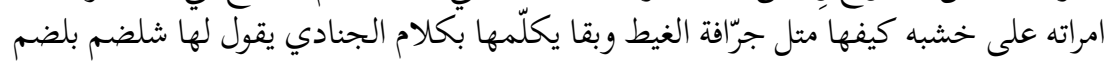

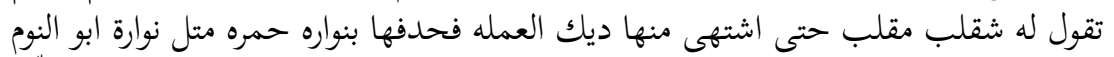

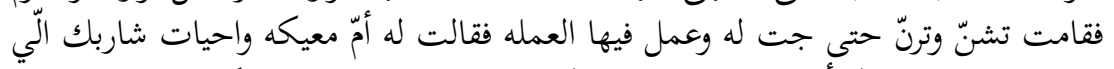

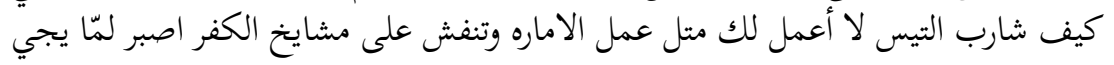
الليل تبلغ مرادك كيف الكيد

\subsection{4}

قال فصبر الفّلاح حتى دخل الليل فقال لها اقعدي في مَدْود الحماره وانا أقعد في مدود البها البقره

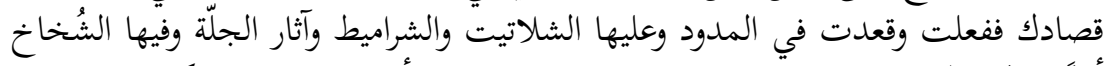

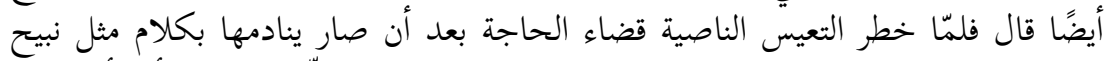

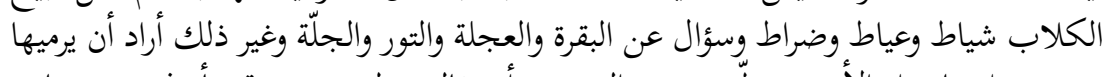

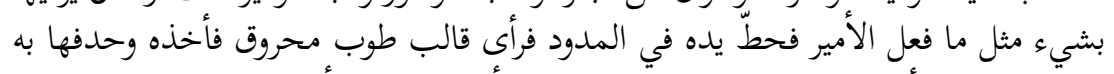

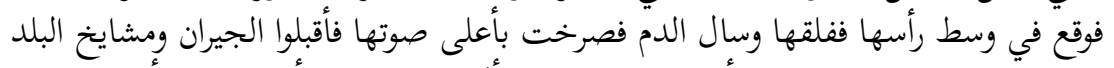

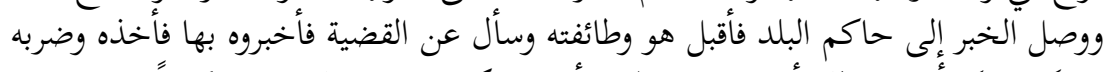

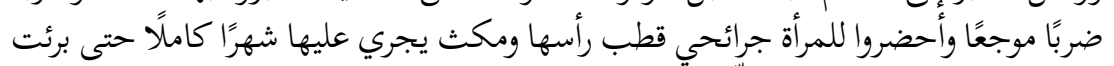

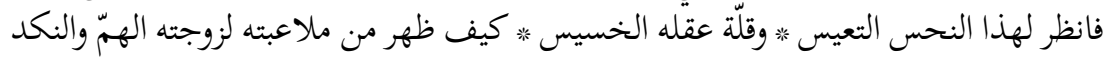

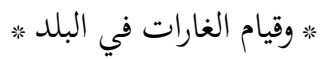

\subsection{5}

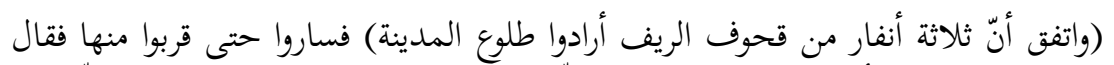

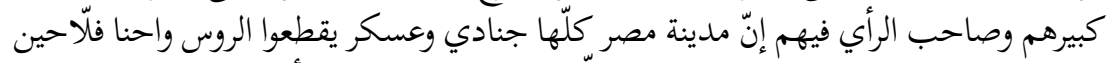

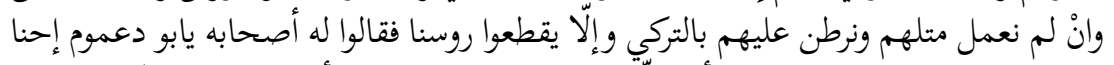

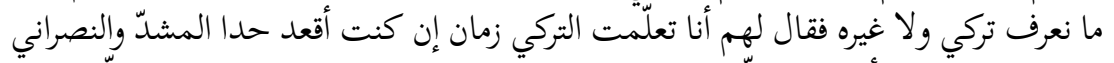

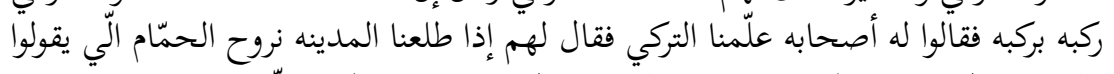

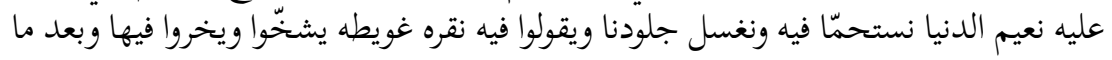

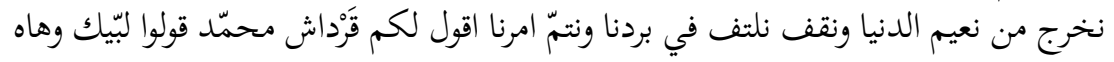




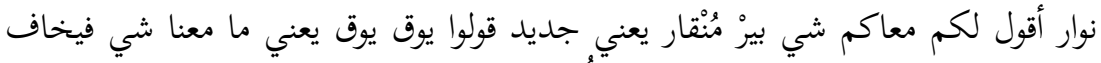

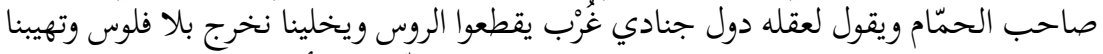

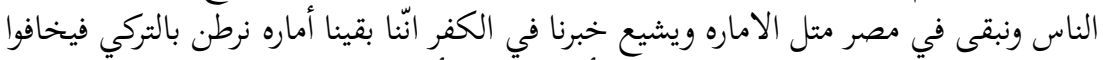

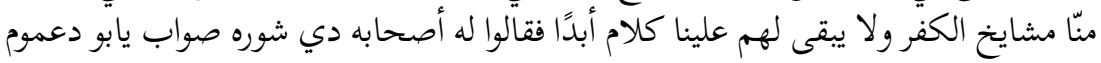

\subsection{6}

قال فساروا حتى طلعوا مصر وسألوا عن الحمّام فدلّوهم عليه فدخلوا وشلحوا الزعابيط وأرموا

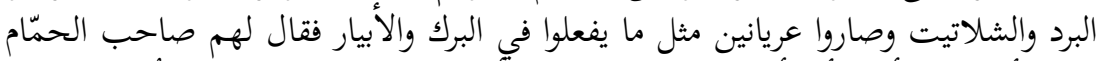

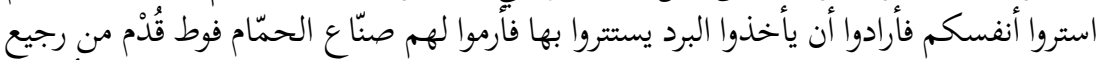

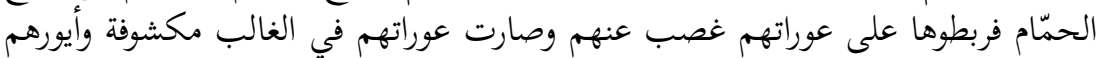

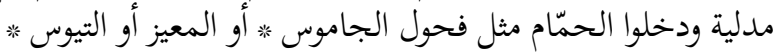

\subsection{7}

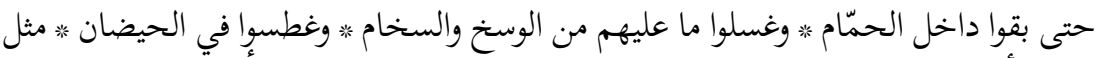

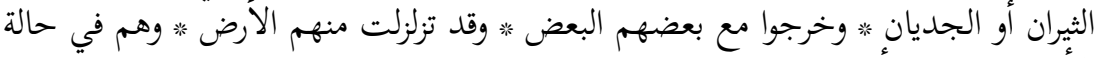

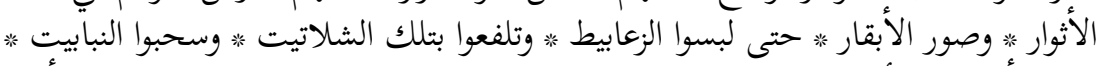

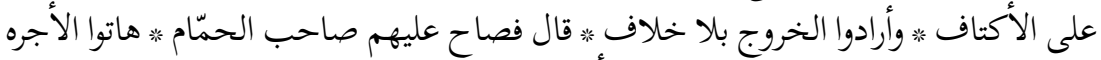

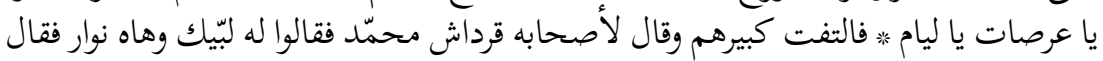

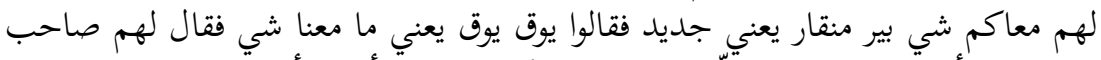

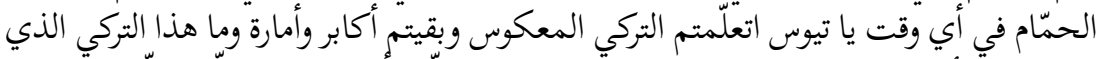

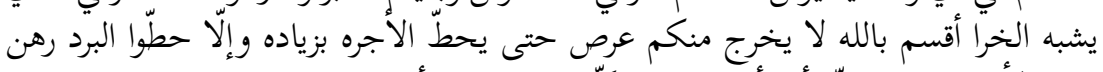

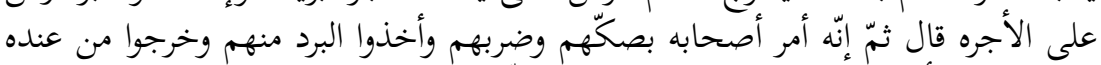

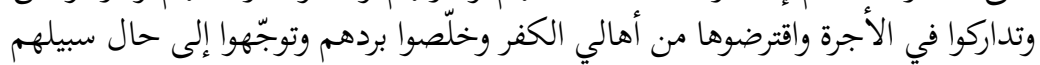

\subsection{8}

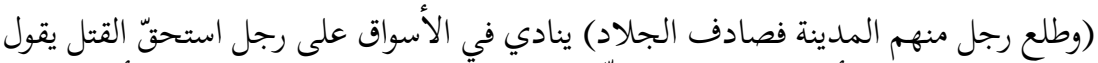

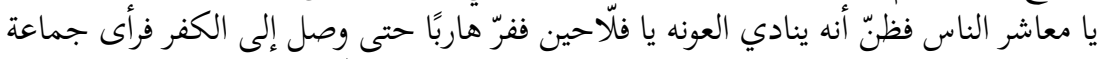

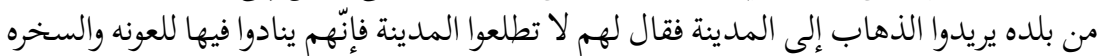

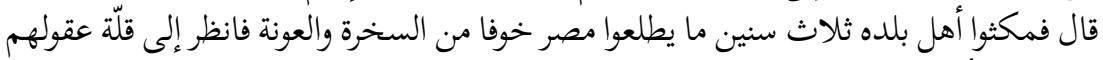
وخساسة رأيهم 


\subsection{4}

(وسأل فقيه ريف بعض العلماء) وقال له مرادي أقرأ الجُرّومية على مذهب الإمام الشافعي فضحك عليه من جهله وطرده

\subsection{5}

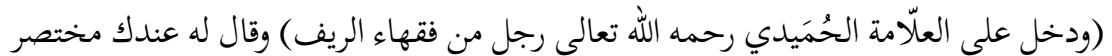

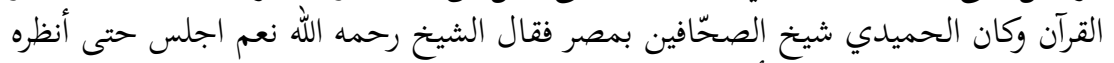

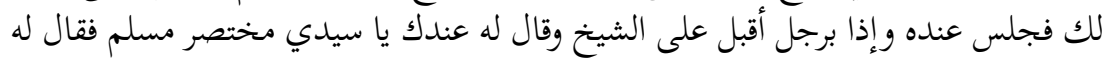

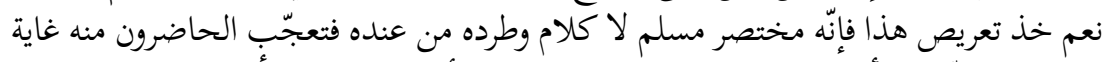

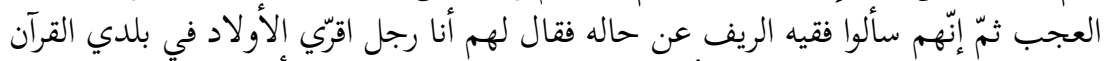

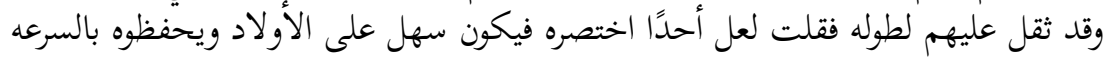
فضحك عليه الحاضرون ومضى إلى حال سبيله

\subsection{6}

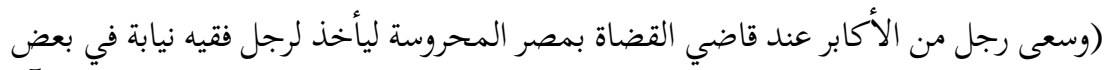

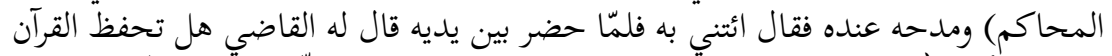

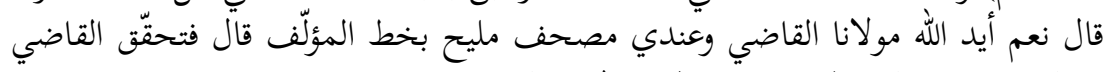
جهله وضحك عليه وطرده فمضى إلى حالى حال سبيله

\subsection{7}

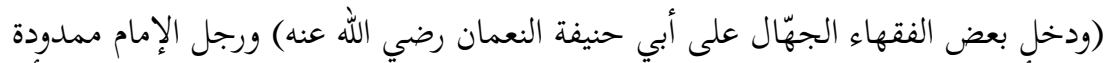

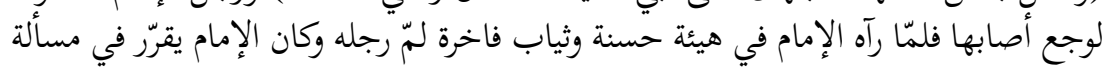

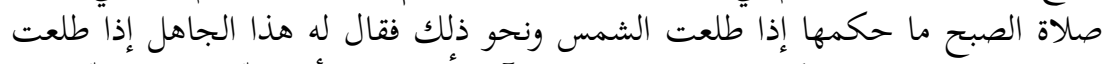

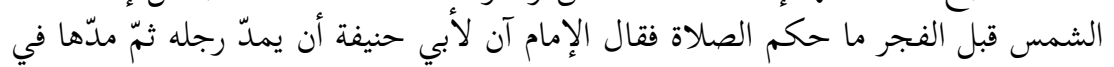
وجهه ومضى على درسه ولم يلتفت إليه الفيه

\subsection{8}

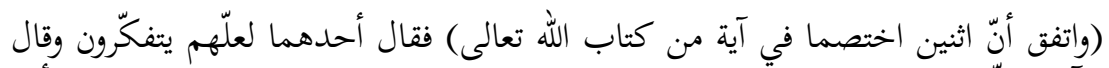

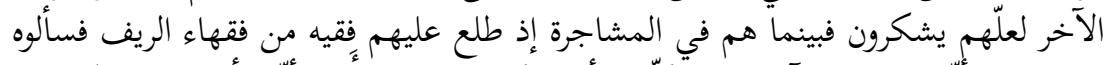

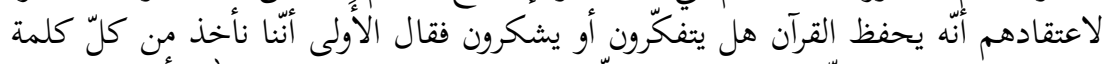

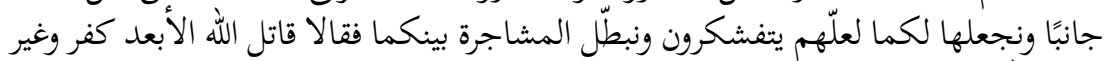
كلام الله 


\subsection{2}

(ودخل بعض العلماء قرية من قرى البحر بنواحي الجبل) فرأى محلًّ يشبه المسجد وفيه البقر

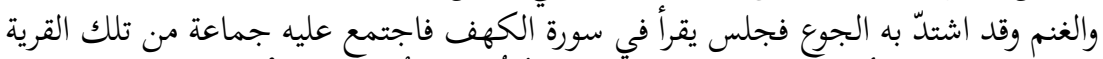

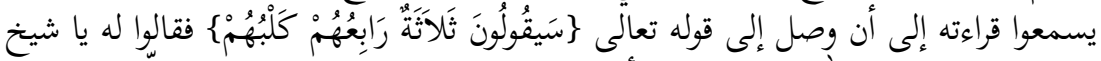

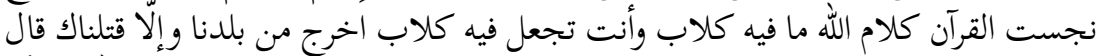

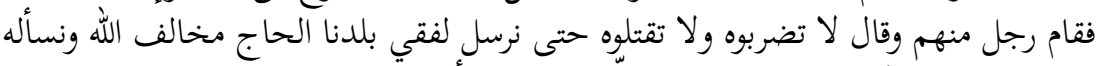

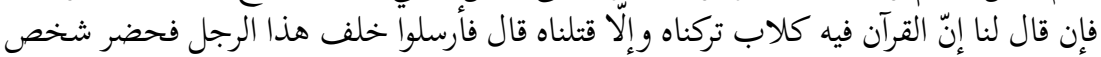

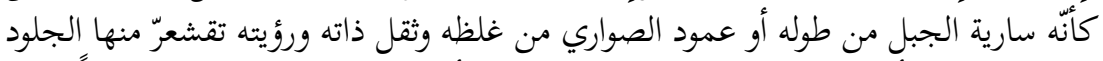

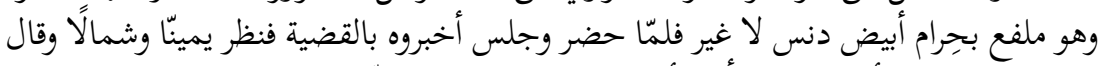

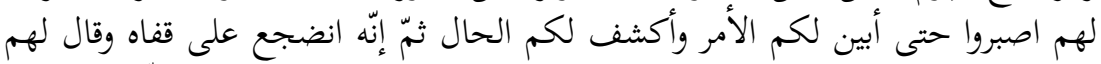

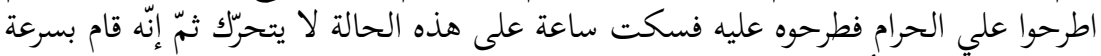

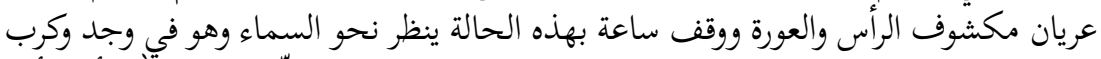

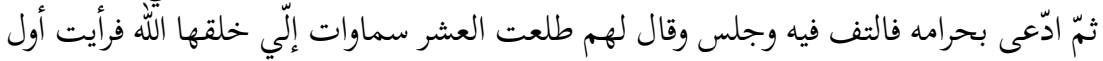

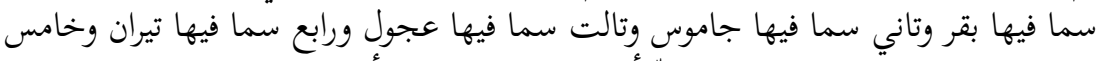

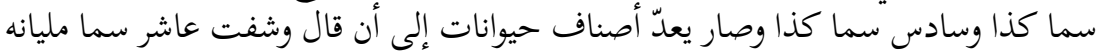

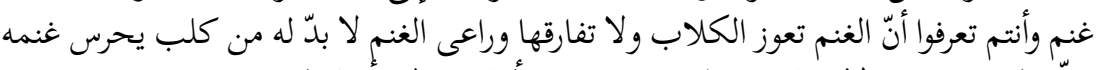

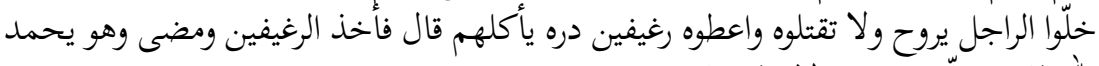

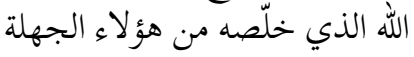

\section{Translation}

Accounts of What Happened to Peasants Who Went to the City

\subsection{2}

And it is said that a peasant came and brought his master his taxes and the latter put him up in a room that had an aperture that overlooked the private quarters of the emir. When night came the peasant said to himself, "I wonder, Abū Mu'aykah, what the emirs do with their women when they're by themselves. Just watch what your master does with his wife and when you go back to the hamlet you can tell Umm Mu'aykah to do it like the emirs 
and she'll pleasure you the very same way. I bet they spout gibberish to one another in Turkish. ${ }^{2}$ Just you watch the way they do it with their women and you'll be able to tell the brave lads, 'Now I'm just like the emirs and Umm Mu'aykah's like the wife of the emir, the master of the village!" So he waited patiently until night came and the emir entered his house. Then the peasant got up and, looking through the aperture, saw the emir sitting on a bed of ivory furnished with all kinds of coverings, and his wife came and sat on another just like it. The emir engaged with her in gentle talk and conversation of a refined sort, now in Turkish and now in Arabic, till, desiring to consummate the act with her, he took a rose from his side and tossed it at her, and she came to him and he luxuriated in her comeliness and beauty to his heart's content, and with the most perfect pleasure, satisfaction, and abandonment, after which each one lay down on his own bed and went to sleep.

\subsection{3}

Come morning, the peasant took leave of his master and set off for his village. When he reached the hamlet, he was met by his wife, Umm Mu'aykah, and she greeted him and they sat down together for a conversation like the converse of apes or the jabbering of Indians, and so it went until she asked him about the city and about the master of the village, and he told her, "Umm Mu'aykah, the city's a fine place and there's nothing that's hard

\footnotetext{
${ }^{2}$ As the language of the Ottoman élite, Turkish was the shibboleth of the military caste.
} 
there except for pissing! ${ }^{3}$ And there's nothing so fair either as our master's wife-she jingles and jangles and wears clothes pretty as poppy flowers, red and yellow, and on her head she wears a cap just like the one that I wear at the Feast that I bought when we got married for a silver piece and a copper piece, and on her wrists she has yellow bracelets made of God only knows whatdate stalks or something. She was wearing a red shift sewn like the sacks we pack fresh-picked beans in and on her legs were anklets like Umm Du'mūm's ${ }^{4}$ that I bought her for five silverpieces-worth of coppers and she was wearing a green jacket, God only knows what she'd dyed it with-clover or something. How fine she looked when they did the thing that people do with women, and I want you, Umm Mucaykah, to do it for me just like she did, so that the people and the shaykhs of the hamlet say, 'Now Abū Mu'aykah's just like the emirs!' Said she, "Tell me, Abū Mu'aykah, what you saw your master's wife do, Abū Mu'aykah." He told her, "When I went to the city and went to the master's and he put me in a room with an aperture looking down into the private quarters and the room where the emir sleeps, I waited till night came, crouched like a snarling dog. Then I saw our master the emir sit down on a black wooden thing tied together with white rags. It had four legs, just like the squash trellis

${ }^{3}$ The reference seems out of place because it has no equivalent in the earlier part of the story. However, jokes about peasants not being able to find a place to relieve themselves in the city are central to other stories that occur later $(1.12 .1,2)$ and were apparently a stock element in the mockery of peasants.

${ }^{4} \mathrm{Umm}$ Du'mūm: presumably a second wife. 
that we put up in the fields at the watermelon harvest. His wife sat down on a wooden thing of the same sort, like the shovelsledge they use to flatten the fields. He started talking trooper talk to her, saying, 'Humpety-tumpety!' and she answered, 'Upsydownsy!' and so it went on till he wanted to do it with her. Then he heaved a red flower like a poppy at her and she got up jingling and jangling and went to him and he did it to her." Said Umm Mu'aykah, "I swear by your billy-goat whiskers, I'll do it for you like the emirs do and then you can preen yourself in front of the shaykhs of the hamlet. Be patient until nightfall and you will attain your desire!"

\subsection{4}

So the peasant waited till night and then said to her, "You sit in the donkey's trough and I'll sit in the cow's in front of you!" So, she did as he said and sat down in the trough in her rags and tatters and traces of dung, not to mention the piss that was on her. When the miserable wretch decided to consummate the act-after he'd engaged with her in converse sweet as the barking of dogs, with hubbub and hullabaloo and farting and questions about the cow and the calf and the ox and the dung cakes and so forth-he wanted to toss something at her as the emir had done, so he put his hand into the trough and saw a piece of burnt brick, which he took and heaved at her. The brick hit her in the middle of her head and cracked it open and the blood ran and she screamed at the top of her lungs, and the neighbors and the shaykhs of the village came and the news reached the chief of 
police of the village, who proceeded to the place with his entourage and enquired into the matter. They told him what had happened and he took the man and beat him severely; and they got the woman a surgeon, who sewed up her head and spent a whole month treating her before she recovered. Observe this wretch with luck ungraced and the stupidity of his mind debased, and how, from his clowning with his wife, sorrow, woe, and mayhem in the village grew!

\subsection{5}

And it happened once that three clods from the countryside decided to go to the city. When they were almost there, their leader and counselor said, "The city of Cairo is all troopers and footsoldiers that cut off people's heads, and we are peasants, and if we don't do as they do and gabble at them in Turkish, they'll chop off our heads." "Abū Du'mūm," said his companions, "we know nothing about Turkish or anything else!" "I learnt Turkish long ago," he answered them, "when I used to sit next to the bailiff and the Christian, knee to knee." So his companions said to him, "Teach us Turkish!" "When we get to the city," he said, "we'll go to the bathhouse, which people call Heaven on Earth, and take a bath and wash our hides-they say it has a deep hole that they shit and piss in! As we're leaving Heaven on Earth and are wrapping ourselves in our cloaks and about to be on our way, I'll say to you, 'Kardeş Mehmet!' ('Brother Mehmet!') and you say, 'At your command!' and 'Hah! Ne var?' ('Huh! What's up?'). 
Then I'll ask you, 'Do you have bir munqār?'5 meaning a copper piece, and you say, 'Yok yok!' meaning 'No, we don't.' Then the bathhouse keeper will get scared and say to himself, 'These are foreign troopers who chop off people's heads!' and he'll let us leave without paying and everyone will stand in awe of us and we'll be treated in Cairo like emirs. Word will spread in the hamlet that we've become emirs and speak Turkish, and the shaykhs of the hamlet will be afraid of us and they'll have no more authority over us at all!" "Sound thinking, Abū Du'mūm!" said his companions.

\subsection{6}

So, they proceeded until they reached Cairo and asked for the bathhouse, and the people directed them to it and they entered, shedding their woolen wraps and throwing their cloaks and the rest of their rags on the ground and leaving themselves naked, just as they do at the ponds and wells. "Make yourselves decent!" the bathhouse keeper told them, and they were about to take their cloaks and cover themselves with those when the bathhouse workers threw them some old, used towels. Like it or not, they had to tie these over their privates, though these remained for the most part exposed, and, penises wagging, they went into the bathhouse, looking like buffalo bulls or billies and bucks.

\footnotetext{
${ }^{5}$ Munqār, i.e., mangrr, an Anatolian Ottoman copper coin, the equivalent of the Egyptian copper piece jadid; see further Pamuk (2000, 38).
} 


\subsection{7}

Once inside, they washed off the muck and the mire, plunging into the tanks like young oxen or kids, and emerged again all together, the ground shaking beneath them as in a tremor, like oxen in condition and cattle in apparition. Then they donned their cloaks, wrapped themselves in their rags, shouldered their cudgels, and were about to leave without more ado, when the bathhouse keeper shouted after them, "Hand over the money, you pimps, you cheats!" At this the leader turned and said to his companions, "Kardeş Mehmet!" to which the others replied, "At your command!" and "Hah! Ne var?" and he said, "Do you have bir munqār?" meaning, "a copper piece" and they answered, "Yok yok," meaning "No, we don't." The bathhouse keeper said to them, "When did you bucks learn this Turkish that sucks and become big men and emirs, and what is this Turkish that sounds like shit? I swear to God, not one of you pimps leaves till he hands over the entrance fee and then some, or you leave your cloaks as pledges for it!" Then he ordered his friends to kick them and beat them and they took their cloaks from them and the peasants left and came up with the fee, which they borrowed from the people of the hamlet, and they redeemed their cloaks and went on their way.

\subsection{8}

And one of these people went to the city and arrived just as the public executioner was crying out "Oyez!" in the marketplaces apropos of a man who had been sentenced to die. The peasant thought that he must be calling, "All peasants to the corvée!" and 
fled back to the hamlet. There he found a party from his village about to set off for the city, so he said to them, "Don't go up to the city, for they're summoning people to the corvée!" and the people of his village then went for three years without going to Cairo, for fear of the corvée. Observe their stupidity and the baseness of their thinking!

Further Anecdotes Showing the Ignorance of Country Pastors

\subsection{4}

And a country pastor asked a question of a scholar, saying to him, "It is my wish to read the Jurrūmiyyah ${ }^{6}$ according to the school of the Imam al-Shāfici." The man mocked him for his ignorance and threw him out.

\subsection{5}

And a country pastor visited the learned scholar al-Ḥumaydī, may the Almighty have mercy on him, and asked him, "Do you have an abridged Qur'ān?" Shaykh al-Humaydī being Shaykh of the Book Traders in Cairo. The shaykh, God have mercy on him, told him, "Certainly. Sit down while I find it for you." So, he sat down. Then another man came to the shaykh and said to him,

\footnotetext{
${ }^{6}$ I.e., the al-Ājurrūmiyyah of Abū 'Abd Allāh Muhammad ibn Dā'ūd alSanhājī, known as Ibn Ājurrūm (672/1273 or 1274 to 723/1323), "the most widely known and used Arabic grammatical textbook of all time [in which] the whole of Arabic grammar is reduced to about a dozen printed pages of easily memorised rules and stereotypical examples" (Carter 1998, 308). The point of the story is that the country pastor does not know the difference between grammar and jurisprudence.
} 
"Sir, do you have an abridged Muslim." "Indeed I do," said the shaykh: "Take this wretch, for he's an abridged Muslim, no two ways about it!" and he threw the pastor out. Those present were utterly amazed and asked the pastor about himself and he told them, "I am one who teaches the children in my village to read the Qur'ān, but they find it boring because it's so long, so I thought maybe someone had abridged it, which would be easier for the children and allow them to memorize it quickly." Those present mocked him and he went his way.

\subsection{6}

And a certain grandee exerted his influence with the chief judge in Divinely Protected Cairo to get a post for a pastor as a deputy judge in one of the courts, singing the man's praises. The judge said, "Send him to me." When the man was before him, the judge asked, "Have you memorized the Qur'ān?" and the man replied, "Yes indeed, God aid Your Worship, and I've got a lovely copy in the author's own handwriting!" The judge saw how ignorant he was and mocked him and threw him out, and he went his way.

\subsection{7}

And an ignorant country pastor paid a visit to Abū Ḥanīfah al$\mathrm{Nu}$ 'mān-may God be pleased with him-at a moment when the imam had his leg stretched out in front of him because of some pain he was suffering from. When the imam saw that the man

\footnotetext{
${ }^{7}$ I.e., an abridged version of the famous collection of Prophetic traditions entitled The Reliable Collection (al-Jāmi` al-Ṣaḥịh), compiled by Muslim ibn al-Ḥajjāj (d. 261/875).
} 
was of dignified appearance and dressed in fine clothes, he drew in his leg. At the time, the imam happened to be giving instruction on the question of the morning prayer and what rule applied should the sun rise during the prayer and so on. ${ }^{8}$ The ignoramus asked him, "What's the rule for the prayer, if the sun rises before dawn?" Said the imam, "It seems it's time for Abū Hanīfah to stretch out his leg again!" and he did so in the man's face and went on with his teaching and paid him no further attention.

\subsection{8}

And it happened that two men differed over a verse of God's Word, one saying la'allahum yatafakkarūn ("perhaps they will bethink themselves"), the other lacallahum yashkurūn ("perhaps they will be grateful"). ${ }^{9}$ While they were arguing, a country pastor appeared, and, believing him to have memorized the Qur'ān, they asked him, "Is it yatafakkarūn or yashkurūn?" That ignoramus told them, "The best thing to do is for us to take a little from each word and make it yatafashkarūn, ${ }^{10}$ and put an end to your quarreling." "God strike you dead!" they said to him. "He has blasphemed, and changed the word of God!"

\footnotetext{
${ }^{8}$ Prayer must not be performed at the precise moment of sunrise, noon, or sunset. Traditions deal with the validity of the dawn prayer if initiated before but completed after sunrise.

${ }^{9}$ The occurrence of nearly identical passages in the Qur'ān increases the difficulty of memorising it. The phrase la-'allahum yatafakkarūn occurs in three places (Q A'rāf 7.176; Naḥl 16.44; Ḥashr 59.21), while la'allahum yashkurūn occurs once (Q Ibrāhīm 14.37).

${ }^{10}$ Yatafashkarūn has no meaning, but is reminiscent of yatafashkalūn 'they are confused or disordered'.
} 


\subsection{2}

And a scholar entered one of the villages on the banks of the river close to the desert and saw what looked like a mosque, with cattle and sheep and goats in it. He was extremely hungry, so sat down and recited from Sūrat al-Kahf, ${ }^{11}$ and a group of people from the village gathered around to listen. However, when he came to the words of the Almighty "Some will say, 'They were three, their dog the fourth',"12 they said to him, "Shaykh, you have defiled the Qur'ān! God's Word has no dogs in it, and you have put dogs in it! Get out of our village before we kill you!" One of them, however, stood up and said, “Don't beat him or kill him till we've sent for the pastor of our village, al-Ḥājj Mukhālif Allāh ${ }^{13}$ and asked him. If he tells us that the Qur'ān has dogs in it, we'll leave him be. If not, we'll kill him!" So they sent for this man and an individual appeared, tall as a flagpole on a mountain and bulky and heavy in physique as the Pillar of the Columns, so that just looking at him was enough to make the skin crawl. He was enveloped in a filthy white blanket and nothing else. When he came and had sat down, they informed him of the situation. He looked to the right and to the left and then said to them, "Be patient till I reveal you the truth and discover you the essence of the matter!" Then he lay down on his back and told them, "Throw the blanket over me!" which they did. He remained thus for a while without speaking or moving, then suddenly leapt up, naked, head

\footnotetext{
${ }^{11} \mathrm{Q}$ 18, Sūrat al-Kahf.

${ }^{12} \mathrm{Q}$ Kahf 18.22.

${ }^{13}$ Mukhālif Allāh literally 'He who disagrees with God'.
} 
and privates exposed, and stood thus for a while gazing into the sky in a state of ecstatic agony. Eventually, he called for his blanket and wrapped it about him and sat down. "I have visited the Ten Heavens that the Almighty created," he said, "and I saw that in the First Heaven are cows and in the Second Heaven buffalos and in the Third Heaven calves and in the Fourth Heaven oxen and in the Fifth Heaven such-and-such and in the Sixth Heaven such-and-such" and he went on enumerating the various types of animals until he said, "and I saw that the Tenth Heaven was full of flocks of sheep and goats, and as you know flocks need dogs, which they are never without, and the shepherd has to have a dog to guard his flocks. Let the man go and do not kill him, and give him two loaves of corn bread to eat!" So the scholar took the two loaves and went away, praising the Almighty for saving him from those ignoramuses. 



\title{
6. A WEAVER'S NOTEBOOK FROM ALEPPO (10TH/16TH CENTURY)
}

\author{
Boris Liebrenz and Kristina Richardson
}

At the end of the 10th/16th century and the beginning of the 11th/17th century, the Aleppine Kamāl al-Dīn, a weaver by profession, kept a notebook. ${ }^{1}$ Only a small fragment of it seems to have survived, held since the early 19th century in the Forschungsbibliothek Gotha in Germany. The remaining folios, from the years 997 and 998, contain descriptions of political and economic events, of meetings with friends and events in the market, or the weather; obituaries; riddles and sayings; stories and excerpts from books on history, religion, and law; a multitude of poems, many of his own making; in short, anything that this weaver deemed interesting to record at any point.

Kamāl al-Dīn had a keen interest in reading, literature, and scholarship, but was not a career scholar himself. While he had studied several sciences to some degree in his youth (fol. $55 \mathrm{v}$ : alma'qūlät wa-l-fiqh wa-'iddat 'ulüm), his only teacher held a minor post and remains unknown outside of Kamāl al-Dīn's notebook.

\footnotetext{
${ }^{1}$ The notebook, its place in Arabic literature, as well as the biography of its author are the object of an extended study that will accompany our edition of the text, to appear within the series Bibliotheca Islamica at the Orient-Institut Beirut.
} 
Colloquial language is a feature of the poetic genre called zajal, in which the author works several times. He does not willingly employ it in his prose. Kamāl al-Dīn certainly makes several smaller mistakes in these passages. Yet his idiosyncrasies rarely exceed contemporary manuscript practices. These practices include the replacement of an 'alif maqșüra with a $y \bar{a}$ ', of a hamza with a $y \bar{a}^{\prime}$, or the omission of the points on the $t \bar{a}^{3}$ marbutta. Thus, the sole instance of the word اعطيطك in our sample probably serves as an attempt to introduce an element of spoken language into the story and to mark the speaker as an uneducated worker.

For the edition, we have adopted a set of orthographic standardisations to make the text more accessible: $t \bar{a}^{3}$ marbūta with points; 'alif maqșūra without dots; hamza where necessary. We have also added some modern punctuation.

\section{Transcription}

Story of a hashish addict

MS Gotha orient. A 114, fol. 7r

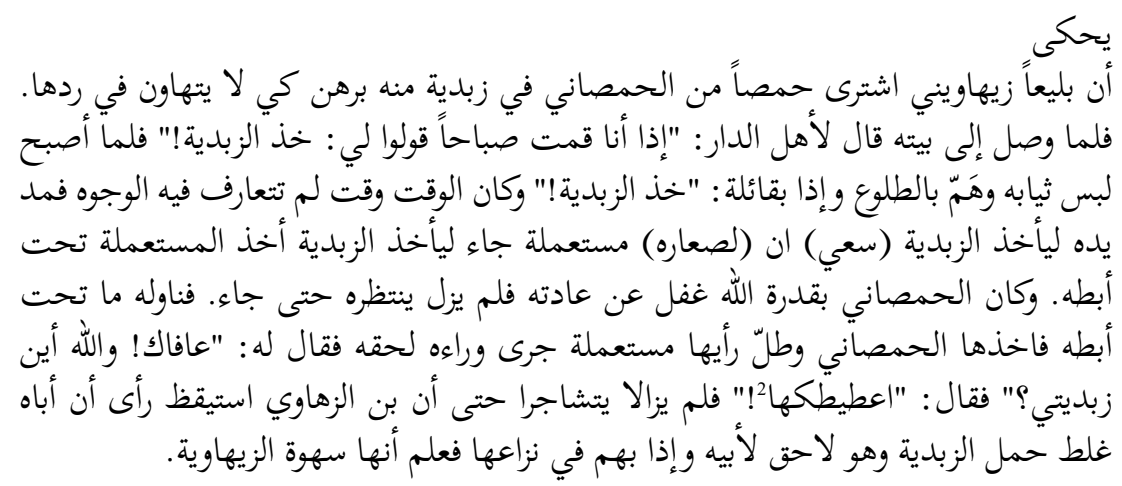

كذا، والصواب: أعطيتك إياها. 2 


\section{Translation}

It is told

that a hashish swallower bought hummus from the hummus vendor in a zabdiyya bowl that he borrowed from him against collateral, so that he wouldn't neglect to return it. When he came home, he said to the people of the house: "When I get up in the morning, say to me: Take the zabdiyya!" And when he awoke, he dressed and wanted to get out, there was a woman saying: "Take the zabdiyya!" This was at a time when one could not tell faces apart. So, he stretched out his hand to take the zabdiyya, (...) there was a chamber pot. He wanted to take the zabdiyya, but took the chamber pot under his armpit. And the hummus vendor, through God's power, against his usual habit, waited until he came. He handed over what he had under his armpit and the hummus vendor took it. When he saw that it was a chamber pot he came after him, reached him, and said: "Please! By God, where is my zabdiyya?" He said: "I gave it to you!" They wouldn't stop arguing until the son of the hashish addict woke up and saw that his father had erred in picking up (what he thought was) the zabdiyya. When he reached his father, there they were, fighting over it. Then he realised that the cause was the absent-mindedness of hashish addicts.

\section{Commentary}

زيهاويني. Cf. the form الزهاوي later in the same story. It is clear already from Kamāl al-Dīn's own use of the term in several locations (see the stories on fol. $22 \mathrm{v}$ and the judge on hašǐs on $58 \mathrm{r}$ ) that it must have something to do with drug abuse. Furthermore, 
a connection is apparent with زيّيه, which Șafī al-Dīn al-Ḥillī (d. 749/1350) used to mean 'hashish'. In his commentary on alHillì's verse, Bosworth (1976, II: 309) noted the following: "Zìh 'hashish' is a common term in the literature of hashish consumption from Ayyūbid and Mamlūk times onwards, with zayyāh occurring for 'hashish addict' (...)."

زبدية. A large bowl or deep dish.

. Meaning it was too dark to discern shapes.

أعطيتك إياها Instead of. 


\title{
7. SELECTIONS FROM ARABIC GARSHŪNİ MANUSCRIPTS IN THE BRITISH LIBRARY
}

\author{
Michael Erdman
}

In the history of writing and literacy in the Middle East, Arabic written in Syriac characters, known as Arabic Garshūnī, presents us with an interesting, yet often forgotten, example of cultural adoption and adaptation. Arabic Garshūnī, similar to other allographic traditions, did not have a standardised orthography on which authors and scribes might base their writings. Nonetheless, the general need for language to function as a means of communication and wide dissemination of information implied that certain patterns were adhered to across the Christian Arab world. Previously, the corpus of Arabic Garshūnī manuscripts was limited to Levantine and southern Turkish sources, but an increase in our access to digitised manuscripts from Iraq and other regions has helped to broaden our understanding of this particular means of recording and reproducing cultural heritage (McCollum 2014, 16-19).

Within the patterns referred to above, the use of Syriac graphemes to represent Arabic sounds can be broken down into three separate categories: those for which there is a one-to-one correspondence between Arabic and Syriac graphemes; those 
cases in which Syriac lacks a unique means of representing an Arabic phoneme or grapheme; and a third subset in which the Syriac script represents Arabic phonemes through the use of diacritics. It should be noted that the distinction between phoneme (a unique sound in a phonetic system) and grapheme (a unique letter in a writing system) is important here. The decision to match a grapheme to a grapheme, a phoneme to a phoneme, or a phoneme to a grapheme (and vice versa) tells us as much about the copyist's grasp of Classical Syriac and Classic Arabic as it does about their particular dialect of spoken Arabic (McCollum 2014, 227).

The first category of mappings presents the least difficulties. Here, a one-to-one correspondence is established and is easily recognizable. Thus, the Arabic letter $b \bar{a}^{3}$, for example, is represented by the Syriac letter bèt. Within this category, however, we also find that the core Arabic graphemes function as representatives of the Arabic graphemes based on them, regardless of pronunciation. In this respect, the Syriac yōd is used for both the Arabic $y \bar{a}^{\prime}$ and the Arabic 'alif maqșūra, despite the latter's pronunciation as an 'alif.

The second group of graphemes are slightly more problematic, but they do reveal the pre-modern scribe or writer's understanding of phonetics. Take, for example, the velarised consonants, for which there are two graphemes in Syriac and four in Arabic. In general, those who wrote in Garshūnī sought to replicate sounds by both the șâdē with a dot over it and the tẹt with a dot under it. This raises the question of vernacular pronuncia- 
tions of these letters among the Arabic-speaking Christian communities of the Middle East. In particular, it focuses our attention on the merging of the velarised phonemes in some dialects, such as Lebanese, which are still present in others, such as Najdì and Khalījī Arabic.

Finally, the third collection of graphemes is the most unstable: those that can be represented fully in Syriac with the help of diacritics, the most common of which is the rukāka , a dot below the letter. Here, the Arabic ghayn is rendered with the Syriac gāmal and a dot below, the traditional Syriac means of rendering the voiced pharyngeal fricative. Occasionally, a conscientious scribe would also use a qūshāyā, or a dot above the letter, to indicate that it was to be read as the corresponding non-spirantized letter in Arabic. The problem with this group of graphemes is that the usage of the dot is far from routine. The reader is thus left asking herself if this phenomenon-which rarely impedes comprehension-is a reflection of vernacular phonology or simple laziness on the part of the scribe.

A final remark must be made on additional markers used in Arabic texts. The hamza, although a separate letter according linguists, never features in Garshūnī texts. When it would sit on an 'alif, waw or $y \bar{a}$ ' in Arabic, the basic grapheme is used. Harakāt may or may not be included in a text and almost always follow the Arabic system, rather than either of the two Syriac systems in use. Similarly, two dots over the letter assist us in determining whether a final $h \bar{e}$ is intended to be a $t \bar{a}^{3}$ marbūta or a final $h$. Lastly, the shadda occasionally appears in its Arabic form. On other occasions, it shows up as a tilde over the doubled consonant 
or a neighbouring one. Gemination was rare enough in Classical Syriac that it did not merit its own special diacritic.

The full listing of the most common orthography is found in the table below:

\begin{tabular}{|c|c|c|c|c|c|}
\hline Arabic & Garshūnī & Arabic & Garshūnī & Arabic & Garshūnī \\
\hline 1 & r & ش & $\Sigma$ & b & סף \\
\hline ب & $=$ & ص & 5 & ن ن & - \\
\hline ت & $x / d$ & ض & t.s & g & o \\
\hline$\dot{~}$ & $x$ & $b$ & $\downarrow$ & ي & , \\
\hline ج & $->$ & ظ & $t / t$ & 。 & m \\
\hline$\tau$ & w & $\varepsilon$ & $\sim$ & $s$ & - \\
\hline$\dot{r}$ & $n$ & $\dot{\xi}$ & $\lambda$ & $T$ & $r$ \\
\hline د & i & ف & 9 & ؤ & 0 \\
\hline ذ & 3 & ق & مـ & ة & $\ddot{m}$ \\
\hline J & $i$ & 5) & $i / n$ & s & , \\
\hline j & 1 & \rfloor & \lrcorner & s & , \\
\hline س س & $\infty$ & & & & \\
\hline
\end{tabular}

In traditional Syriac texts, similar to those in Hebrew and Arabic, the letters are also assigned numerical values. These numbers are often denoted by a line over the individual graphemes. This tradition was carried over into many of the Garshūnī texts used in this section.

The traditional Syriac system of numeration is as follows (Healey 2005, 93):

\begin{tabular}{|c|c|c|c|}
\hline Syriac Grapheme & Numeral & Syriac Grapheme & Numeral \\
\hline r & 1 & \lrcorner & 30 \\
\hline 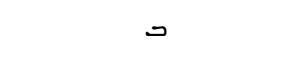 & 2 & ס & 40 \\
\hline 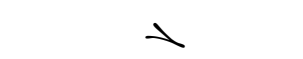 & 3 & - & 50 \\
\hline$x$ & 4 & $\infty$ & 60 \\
\hline m & 5 & $\sim$ & 70 \\
\hline a & 6 & و & 80 \\
\hline
\end{tabular}




\begin{tabular}{cc|cc}
$i$ & 7 & 5 & 90 \\
$w$ & 8 & 5 & 100 \\
$t$ & 9 & $i$ & 200 \\
, & 10 & $x$ & 300 \\
$u$ & 20 & $x$ & 400 \\
\hline
\end{tabular}

\title{
British Library Or MS 4435; 12 r
}

\section{Transcription}

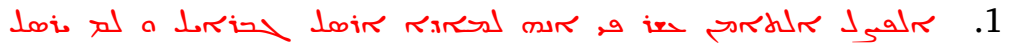 \\ în \\ 2.

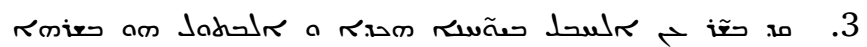 \\ 4.

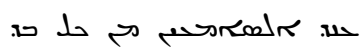

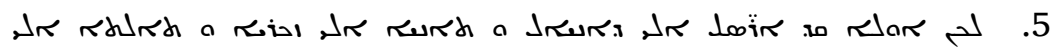 \\ S \\ 6.

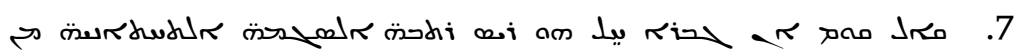

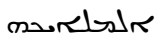 \\ 8. \\ 9. \\ 10.

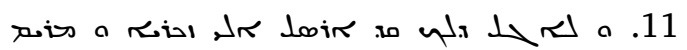

\section{Arabic Transcription}

$$
\begin{aligned}
& \text { 1. الفصل التامن عشر في انه لمادا ارسل جبرايل و لم يرسل ملاك اخر. } \\
& \text { 2. } \\
& \text { 3. }
\end{aligned}
$$

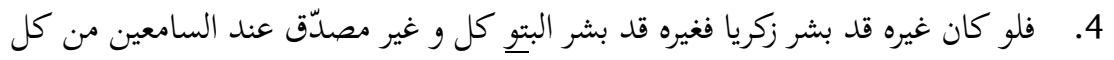

$$
\begin{aligned}
& \text { بل } \\
& \text { 5. لكن اولا قد ارسل الي دانيال و تانيا الي زكريا و تالتا الي مريم }
\end{aligned}
$$

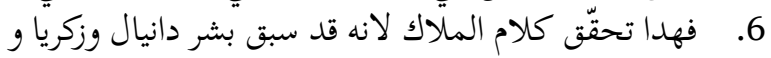




$$
\begin{aligned}
& \text { 7. } \\
& \text { 8. }
\end{aligned}
$$

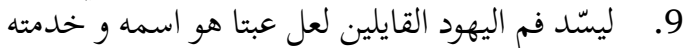

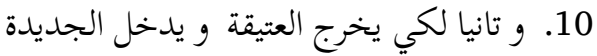

$$
\begin{aligned}
& \text { 11. و و لاجل دلك قد ارسل الي الي زكريا و مريم }
\end{aligned}
$$

\section{Translation}

(1) Section 18, regarding why Gabriel was sent and not another angel. (2) We say that it was the same as in the case of Daniel, (and) when Gabriel came to Zachariah. (3) He similarly presaged the pregnancy (of Elizabeth) with John and he also brought good tidings to the Virgin. (4) So, if it had been someone else who brought good tidings to Zachariah, it would also have been someone else who brought good tidings to the Virgin. And someone else would have been believable to the listeners in any case. (5) But first He sent [him] to Daniel, and second to Zachariah, and third to Mary. (6) This proves the words of the angel, because previously he brought good tidings to Daniel and Zachariah. (7) Some people said that Gabriel is the head of the lower stream of His angels. (8) And He sent this one because his name was already associated with Daniel in the Old [Testament] (9) in order to shut the mouths of Jews who were saying that perhaps his name and task were not to be taken seriously; (10) and secondly so that he [Gabriel] would leave the Old [Testament] and enter the New [Testament]. (11) And for that reason, He sent him to Zachariah and Mary.

\section{British Library Or MS 7205, 1v}

A book of Christian theology in questions and answers 


\section{Transcription}

$$
\begin{aligned}
& \text { 1. } \\
& \text { 2. } \\
& \text { م مאلd } \\
& \text { 3. }
\end{aligned}
$$

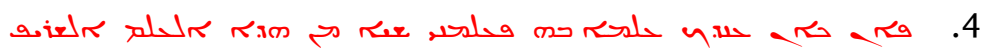

$$
\begin{aligned}
& \text { yirastro }
\end{aligned}
$$

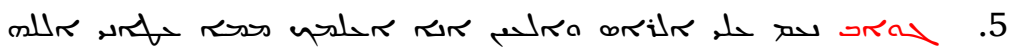

$$
\begin{aligned}
& \text { 6. }
\end{aligned}
$$

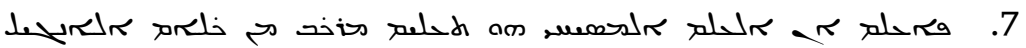

$$
\begin{aligned}
& \text { r }
\end{aligned}
$$

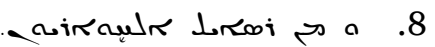

$$
\begin{aligned}
& 9 \\
& \text { 10. } 0 \\
& \text { 11. }
\end{aligned}
$$

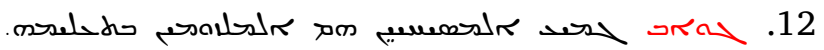

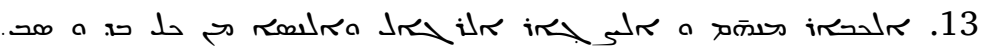

\section{Arabic Transcription}

$$
\begin{aligned}
& \text { 1. } \\
& \text { 2. }
\end{aligned}
$$

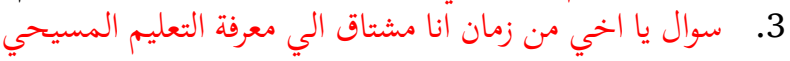

$$
\begin{aligned}
& \text { 4. }
\end{aligned}
$$

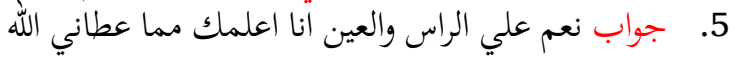

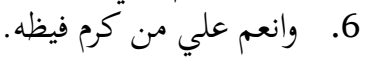

$$
\begin{aligned}
& \text { 7. فاعلم ان ألعلم المسيحي هو تعليم مركب من كلام الانجيل المقدّس }
\end{aligned}
$$

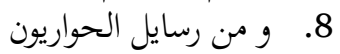

$$
\begin{aligned}
& \text { 9. و و كوساطة هذا الكلام المسيحي تعلم ما ينبغي له } \\
& \text { 10. و و ما هو طروري لامر خلاصه الآبدي. } \\
& \text { 11. سوال اتدري من هم الملزومين ان تعلموا هدا التعليم المفيد }
\end{aligned}
$$

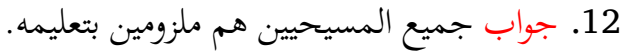

$$
\begin{aligned}
& \text { 13. الكبار منهم والصغار الرجال و النسا من كل بدو سبب. }
\end{aligned}
$$




\section{Translation}

(1) In the name of the Father, the Son and the Holy Ghost, the Sole God, amen. (2) The Book of Teaching for a Christian, by means of Questions and Answers between the teacher and the student. (3) Question: Oh, my brother, for some time now, I have been doubtful about the Teachings for Christians. (4) If you are in possession of any knowledge about it, impart upon me something from this honourable, blessed knowledge. (5) Answer: Yes, on [my] head and [my] eye, I will teach you what God has given me (6) and has bestowed upon me from the garden of his abundance. (7) I shall teach [you] that Christian knowledge is teaching composed of the Word of the Holy Gospels (8) and from the epistles of the Apostles. (9) And as a medium of this, the Word of the Lord [Messiah] taught what was necessary for this, (10) and what was essential, for the issue of eternal salvation. (11) Question: Tell [me], who are they who should learn this useful teaching? (12) Answer: All Christians are required to learn it. (13) Adults among them and children; men and women; for all desires and reasons.

\section{Commentary}

The above extracts come from two Garshūnī Arabic manuscripts housed at the British Library. I have sought to mirror the texts as closely as possible, and have therefore left in as many idiosyncrasies as can be reflected in a word-processed document.

Information about the provenance of these manuscripts is scant at best. For the most part, British Library records provide 
only the title of the work, its pagination, and the date of its acquisition. Garshūnī manuscripts were sourced from across the northern Middle East, including modern day Syria, Turkey, and Iraq. As such, they represent the copying traditions of these communities.

The first extract, Or. 4435 is a collection of stories to be told at Christian festivals. I have chosen a short extract explaining angelic visitation. The manuscript itself was likely copied in the 19th century in the vicinity of Malatya, Turkey (Margoliouth 1899, 42). More information can be gleaned from the catalogue of Forshall and Rosen (1838) for the second extract, Or. 7205. This Catechism in the form of questions and answers, we learn from the catalogue, is likely to have been penned in the 15 th or 16th century. An addition at the back of the manuscript tells us that it was purchased by Father Elyas from Father Suleiman of Mosul in 1799. From this we know that the work was likely still in use until the end of the 18th century (Forshall and Rosen 1838, 101).

Most of the unique attributes of Garshūnī mapping can be seen in both manuscripts. Consider, to start with, the repurposing of the têt, equivalent of the Arabic $t \bar{a}$, as a $d \bar{a} d$, which is seen only in the extract from Or. 7205 :

Or. 7205

Line 6

of. fayțihi [fayḍihi] 'his abundance' 
Line 10

in๖ țarūrī [ḍarūrī] 'necessary'

Next, we find in the two texts the use of the gämal to reflect both the Arabic jim and ghayn:

Or. 4435

Line 2

Lrin Gibrā'il [Jibrā'il] 'Gabriel'

Line 4

mic a fa-law kān gayroh [fa-law kāna ghayrihi] 'if it were not him'

Or. 7205

Line 5

דra gawāb [jawāb] 'answer'

Line 13

in shal-ṣigār [al-ṣighār] 'the small ones'

Finally, the following examples demonstrate the lack of transference of complete Arabic orthography into Arabic Garshūnī, with an example of a lack of hamza:

Or. 4435

Line 11

$\perp^{\prime}$ li-agal [li-ajli] 'because'

Or. 7205

Line 8

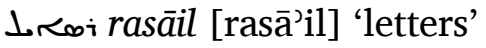

As a final remark, the texts under examination, along with many of the other Arabic Garshūnī texts in the British Library collections, do not demonstrate usage of Syriac lexical items in any notable proportion. Nonetheless, it is interesting to point out the 
carry-over of some of the biblical names in their Syriac orthography, such as

Or. 4435

Line 2

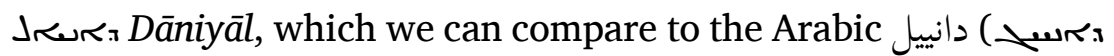
in Arabic Garshūnī orthography) and the Syriac Sarux. 



\section{EXCERPT FROM YŪSUF AL-MAǴRIBİ'S DAF` AL-IȘR 'AN KALĀM AHL MIṢR (1606)}

Liesbeth Zack

The following is an excerpt from Daf' al-iṣr 'an kalām ahl Miṣr, 'Removing the burden from the speech of the Egyptians' (henceforth Daf' al-iṣr), written in the year 1014-1015/1606 by the Egyptian Yūsuf 'Abū al-Mahāsin Jamāl al-Dīn b. Zakariyyā b. Ḥarb al-Mag̉ribī al-Mișrī al-'Azharī (ca. 1562-1611).

Al-Magribī was born and raised in Cairo as the descendent of North African immigrants. He grew up in the Ibn TTūlūn quarter, which was the meeting point for North African pilgrims, and the living quarter of a large number of North African immigrants. After first being set up in the fabric trade by his uncles following the death of his father, al-Magribī went to study at al-Azhar University and subsequently worked in a government position. AlMağribī knew Persian and Turkish and translated some literary works from these languages into Arabic, but these translations have not survived. ${ }^{1}$ He does, however, comment on Turkish and

\footnotetext{
${ }^{1}$ For more information on al-Magribī's life and works, see Zack (2009, 9-19).
} 
Persian words and phrases and cites some poetry in these languages in Daf' al-iṣr.

Daf‘ al-issr is a dictionary of Egyptian Arabic words that alMaġribī checked for consistency with Classical Arabic, mainly using al-Fīrūzābādī's (1329-1415) al-Qāmūs al-Muhịt as his reference, but also citing from the Qur'ān and hadìth and from Classical Arabic poetry. Al-Magribì introduces the Egyptian words and phrases by the word yaqūlūna 'they say', which was usual in the so-called laḥn al-'āmma literature. Al-Mağribī was acquainted with this genre, having written an arrangement of, and appendix to, al-Harīrī's Durrat al-gawwās fì awhām al-xawāṣ̦. However, alMagribī's objective was the opposite of that of the lahn al-'ämmaliterature, because whereas the authors of lahn al-' $\bar{a} m m a$ works set out to correct 'mistakes' that people made in the Arabic language, al-Mağribī’s purpose for writing Daf‘ al-iṣr was to prove that many words and expressions that were generally thought to be 'incorrect' actually had equivalents in the Classical Arabic language (Zack 2009, 31-32; see Pellat (2012b) on lahn al-'āmma literature). If a word used in the Egyptian dialect was found with the same meaning either in one of the Classical Arabic dictionaries, in the Qur'ān or hadìth, or in Classical Arabic poetry, alMaǵribī would classify it as șahịh 'correct'; if not, he would comment in terms of lam yu lam 'it is unknown', wa-laysa ka-dālik 'it is not like this', gayr șahịh 'incorrect', and similar phrases (Zack 2009, 50-51). 
Besides being an important source for Egyptian Arabic in the 17th century, ${ }^{2} D a f^{`}$ al-iṣr also contains numerous interesting observations on Egyptian culture, such as games, food and drink, clothing, and household utensils. Al-Mağribī also makes comments about his own friends and acquaintances as well as about noteworthy events, as the selected text fragment will show. AlMağribī often digresses from the original word under discussion. Most of his comments were triggered by reading something in alQāmūs al-muhịt that interested him or that reminded him of something that he had experienced. This is demonstrated in his entry for tabtab 'to pat', where a note in al-Qāmūs al-muhịt about the nickname tabātabā for someone who pronounced the $q \bar{a} f$ as $t \bar{a}^{2}$ reminded him of one of his own acquaintances with the same speech impediment.

Only one manuscript of Daf' al-issr has survived-the autograph, which is kept in the St. Petersburg University library (catalogued under no. MS OA 778). In its present form, it consists of 134 folios, but originally it contained 25 kurrāsas 'quires', of which quires 3-13 have been lost. The manuscript appears to be a first draft of Daf' al-iṣr, as there are a large number of corrections, additions, and comments (such as unzur 'look up') added in the margins in the author's handwriting. ${ }^{3}$ An abbreviated version, based on the complete manuscript, was written by Ibn Abī

${ }^{2}$ Another important source is Yūsuf al-Širbīnīs Hazz al-quhūf fĭ šarh qașid Abi Šādūf, description by Davies (1981), text edition and translation by Davies (2016).

${ }^{3}$ For more information on the manuscript and the contents of Daf‘ alișr, see Zack (2009, 21-35). 
al-Surūr (1589-1590). This book, titled al-Qawl al-muqtadab fimā wāfaqa lugiat ahl Miṣr min lugat al-'arab 'The abbreviated speech concerning what corresponds in the language of the people of Egypt to the language of the Arabs', contains only one-third of the original lemmata of $D a f^{c}$ al-istr, namely those that had the same meaning in Egyptian Arabic and Classical Arabic. Furthermore, it is stripped of all cultural information, poetry, and anecdotes, which is precisely what makes Daf' al-issr an important source of information on Egyptian language and culture in the 17 th century. ${ }^{4}$

The excerpt from $D a f^{\prime}$ al-iṣr presented here is from the chapter $b \bar{a}$ ', section $t \bar{a}^{\prime}$ and the first part of section 'ayn. Note that words are arranged according to the last letter of the root, like in other dictionaries, such as Lisān al-'arab and al-Qāmūs al-muhịt, so that, for instance, the word ' $a z a b$ is found in chapter $b \bar{a}$ ', section 'ayn. The excerpt starts on fol. 16r line 10 of the manuscript, and ends at fol. $17 \mathrm{r}$ line 13 . The orthography is kept exactly as it was written in the manuscript. The text fragment is followed by a translation and commentary.

\section{Transcription}

fol. 16r

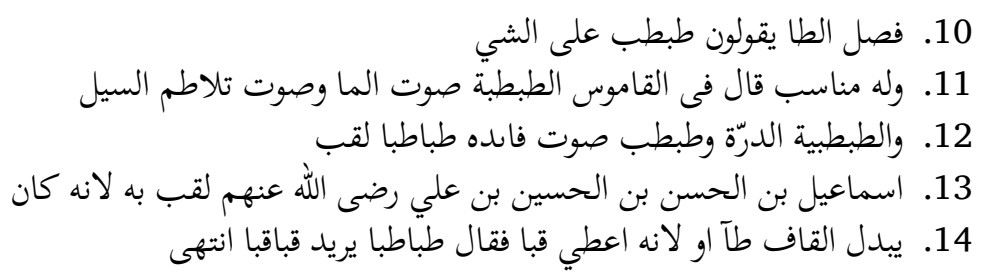

${ }^{4}$ For more information on al-Qawl al-muqtadab see Zack (2009, 35-36). 


$$
\begin{aligned}
& \text { 15. قال الفقير وقد سمعت المرحوم ابن الشيخ الغيطي وكان يبدل حروفا }
\end{aligned}
$$

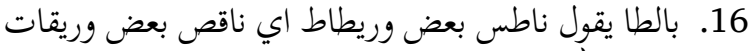

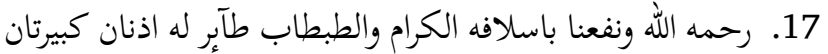

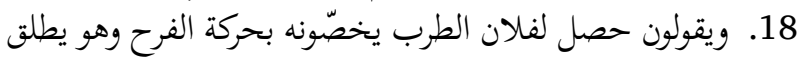

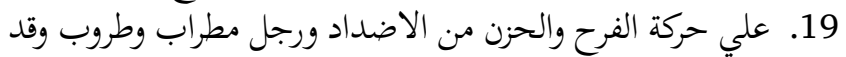

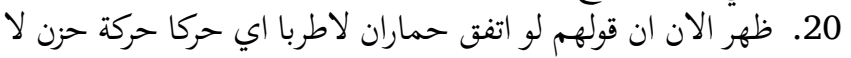

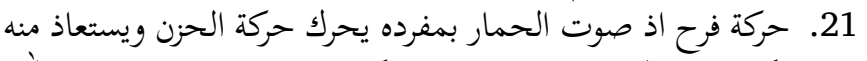

\section{fol. $16 \mathrm{v}$}

1. ويقولون طاب للّني يلعبون به وطابة للكرة ايضا

2.

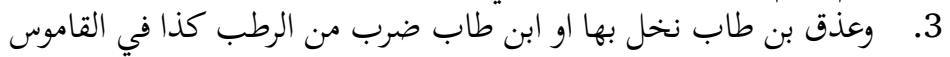

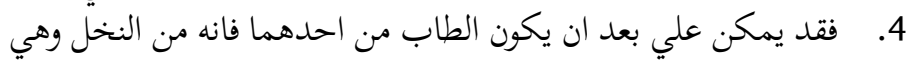

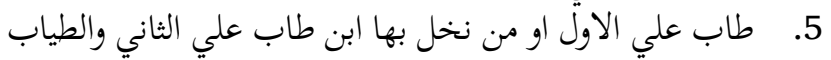

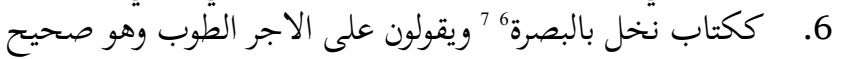
7.

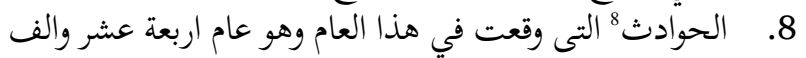

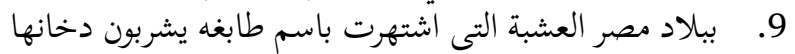

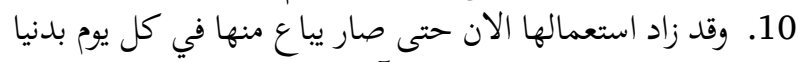

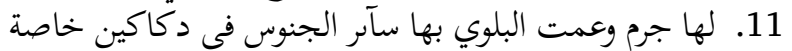

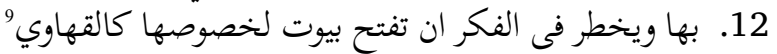

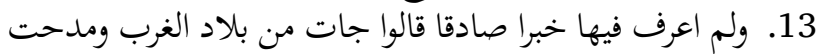

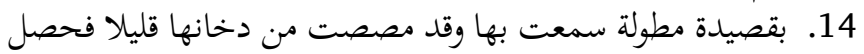

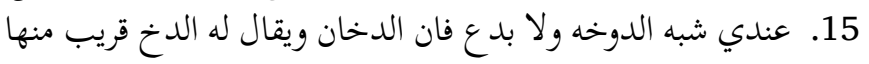

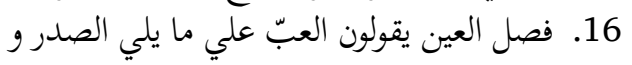

\footnotetext{
انظر الطاب والطابه

واما الطابة فلم تعلم صح : Margin

${ }^{7}$ Margin: ويقولون طاوب لفلان اي انه طاطا في السلام عليه انظرها فيم صليح

${ }^{8}$ Sic.

بيع منها كل رطل بثلاثة ذهب
} 


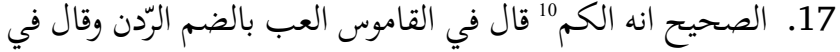

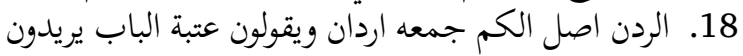

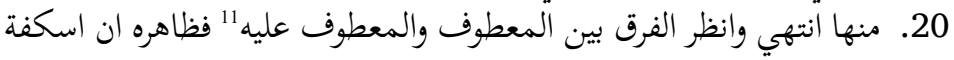

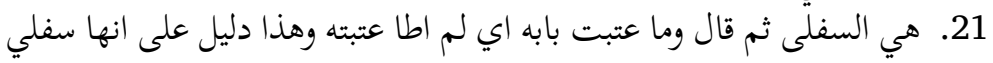

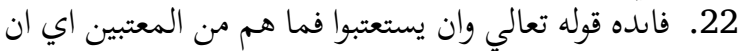

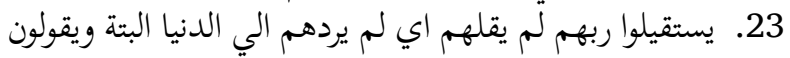

fol. $17 \mathbf{r}$

$$
\begin{aligned}
& \text { 1. عرقب الدابة اذا قطع عرقوبها وهو صحيح واما المثل المشهور }
\end{aligned}
$$

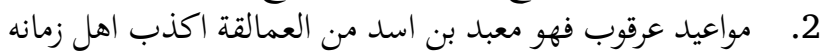

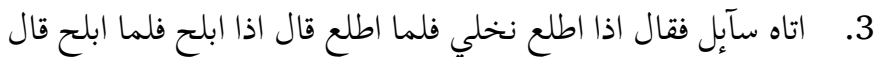

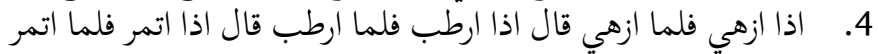

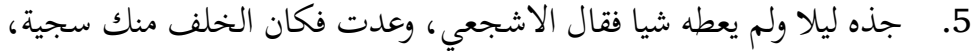

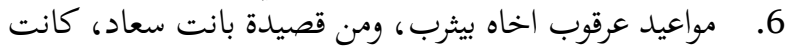

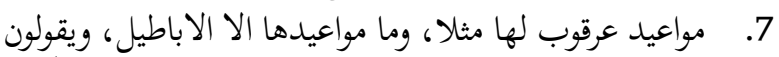

$$
\begin{aligned}
& \text { 8. }
\end{aligned}
$$

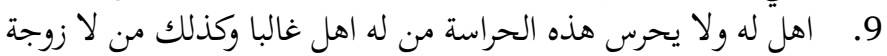

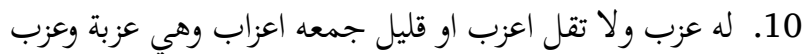

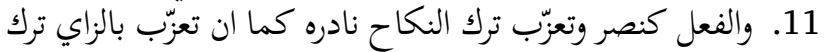

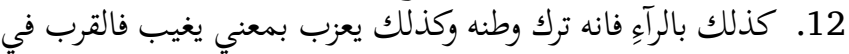

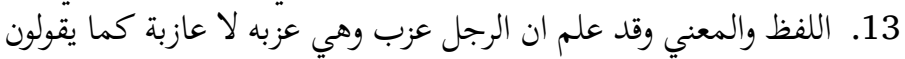

\footnotetext{
10 Margin: العب الكم

11 Margin: انظر الفرق
} 


\section{Translation}

\section{fol. $16 \mathrm{r}$}

(10) Section țā'. They ${ }^{12}$ say: țabțab 'alā al-šay, (11) and this has an equivalent. ${ }^{13}$ [Al-Fīrūzabādī] said in al-Qāmūs: "al-țabțaba is the sound of water and the sound of the dashing of the torrent (12) and al-tabtabiyya is a whip and tabtab is a sound." Interesting fact: "țabătabā is the nickname (13) of Ismā'îl b. al-Hasan b. alHusayn b. 'Alī-may God be pleased with them-which was given to him because he used to (14) replace $q \bar{a} f$ with $t \bar{a}$, or because he was given a $q a b \bar{a}^{3},{ }^{14}$ so he said: tabătabā, but he meant qabāqabā", end [of the quotation]. (15) The faqï ${ }^{15}$ said: I heard the late son of sheikh al-Gayțî, who replaced letters (16) with $t \bar{a}^{\text {'}}$, say nātis ba'd wurayțāt, that is, nāqis ba'd wurayqua $t,{ }^{16}$-(17) may God rest his soul, and we have profited much from his noble ancestors-"Al-tabțāb is a bird with big ears". (18) They say: so-andso experienced al-tarab, which they apply to the agitation ${ }^{17}$ of joy,

\footnotetext{
${ }^{12}$ I.e., the Egyptians.

${ }^{13}$ I.e., it can be found in al-Qāmūs al-Muhịt.

${ }^{14}$ An outer garment with sleeves.
}

${ }^{15}$ Al-Magribī always refers to himself in the third person with the epithet al-faqir 'the poor', or 'living for the Lord alone' (see Nizami 2012 for the use of this term in the context of Sufism). Al-Magribì had connections with some of the Sufi orders in Cairo (see Zack 2009, 15-16). 16 "some little papers are missing"

${ }^{17}$ Lane (1863-1893): "طَرَبْ Emotion, or a lively emotion, or excitement, or agitation, or unsteadiness [...] by reason of joy or grief [...]" (1888a); حَرَكة motion; commotion; agitation" (556b). 
and it is used [in Classical Arabic] (19) for the agitation of both joy and grief, [so this is] one of the words with two opposite meanings, and "a man who is mutrāb and țarūb."18 (20) It seems now that the saying "if two donkeys happen to meet, [their voices] agitate," means that they evoke the agitation of grief, not (21) joy, because the voice of a single donkey evokes grief, from which one should seek protection, (22) so what would it be like if it were doubled? Interesting fact: tarib "like katif" is the name of the horse of the Prophet-God bless him and grant him salvation."

\section{fol. $16 \mathrm{v}$}

(1) They say tâab to [the game] they play, and also țāba to the counter. ${ }^{20}$ (2) I do not know a corresponding [word in Classical Arabic] for these two words. ${ }^{21} \mathrm{Al}-t+\bar{a} b a$ in the [Classical Arabic] language is "wine, and Tayba is al-Madina, (3) and ' $a d q q i b n$ țāb is a type of date palm in [al-Madina], or ibn țāb is a type of date."

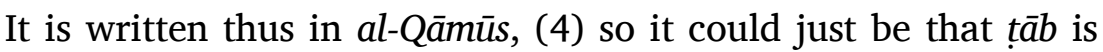
[derived] from one of these two, because it is [made] from the palm tree, so it is (5) tâa from the first one, or it is from the palm trees in [al-Madīna] [called] $i b n t a \bar{a} b$, from the second one. And

\footnotetext{
${ }^{18}$ This means that these are the two adjectives derived from the word tarab, i.e., 'a man who is filled with joy or grief'.

${ }^{19}$ That is, with the same vocalisation as katif.

${ }^{20}$ Literally: 'ball'. See the Commentary below for a discussion of the Egyptian Arabic terms in the text.

${ }^{21}$ Margin: Look up țāb and țāba.
} 
tiyāb (6) like kitāb is a type of palm tree in Bașra. ${ }^{22,23}$ They call baked bricks țüb, and this is correct, (7) and [they call] joking muțāyaba, which is also correct. One of the events (8) events [sic] that happened this year, which is the year $1014,{ }^{24}(9)$ in the land of Egypt, is the herb that has become known under the name of tāboga 'tobacco'. They inhale ${ }^{25}$ its smoke, (10) and its use has now increased to the point that it is being sold every day in a world (11) full of vice and it has become a general necessity, all types in designated shops, (12) and now the idea has come up to open special houses for it like cafés. ${ }^{26}$ (13) I don't have reliable information about it. They say that it came from the West, and it is praised (14) in a long poem that I have heard. I have sucked up a little bit of its smoke and got (15) a kind of dawxa, dizziness, and no wonder, because duxxān 'smoke', which is also called $d u x x$, is close to it. ${ }^{27}$ (16) Section 'ayn. They say $a l-b b$ to that which is next to the chest, but (17) the correct [meaning] is that it is the sleeve. [Al-Fīrūzābādī] said in al-Qāmūs: "al-'ubb with the vowel $u$ is al-rudn, the sleeve," and [al-Fīrūzabādī] said about

\footnotetext{
${ }^{22}$ Margin: As to țāba, it is not known; correct.

${ }^{23}$ Margin: They say: he țāwb to someone, which means that he bowed his head in greeting to him, look this up.

${ }^{24}$ 1605-1606 CE.

${ }^{25}$ Literally: 'drink'.

${ }^{26}$ Margin: A rațl of it is sold for three gold pieces. [Note: the rațl is a unit of weight.]

${ }^{27}$ Here, al-Magribī makes a connection between dawxa 'dizziness' and duxx 'smoke', because they sound similar.
} 
(18) rudn: "the base of the sleeve, its plural is ardān." 28 They say: 'atabat al-bāb, with which they mean (19) that which is at the bottom of the door, and what is written in the Qāmūs is that it is "uskuffat al-bāb, the threshold of the door, and the upper part (20) of it," end of quotation. ${ }^{29}$ It appears that uskuffa (21) is the lower part; then [al-Fīrūzābādī] said " $m \bar{a}$ 'atabtu bābahu means: I did not step upon his threshold," and this is a sign that it is the lower part. (22) Interesting fact: the words of the Sublime and if they ask amends yet no amends shall be made to them ${ }^{30}$ mean that if (23) they ask their Lord to forgive their fault, he will definitely not do so, which means that he will not return them to the world. They say

\section{fol. $17 \mathbf{r}$}

(1) he ' $a r q a b$ the riding animal, if he hamstrung it, which is correct, and as for the famous expression (2) "the promises of 'Urqūb, this is "Macbad b. Asad, one of the Giants, who was the most untruthful person of his time. (3) Once a beggar came to him, so he told him: when my palm trees put forth the spadix [I will give you alms $],{ }^{31}$ so when that happened, he said: when it brings forth

\footnotetext{
${ }^{28}$ Margin: $a l-b b$ is the sleeve.

${ }^{29}$ Margin: Look up what the difference is between the two conjuncts. [Note: Al-ma'tüf and al-ma'tüf 'alayhi: a word to which another word is conjoined, for instance by the particle of conjunction wa-, in this case: uskuffat al-bāb wa-l-ulyā minhā.]

${ }^{30}$ Qur'ān 41:24, translation by Arberry (1963, II:187).

${ }^{31}$ See Lane $(1863-1893,1919 c)$ for the meaning of أطلع النخل. The طَّع., translated by Lane as the spadix (1921b) is a fleshy stem with small flowers that turn into dates if the palm tree is female.
} 
dates, so when that happened, he said: (4) when the redness appears in the dates, and when that happened, he said: when the dates become ripe, so when that happened, he said: when the dates become dry, and when that happened, (5) he cut them off at night, and did not give [the beggar] anything." Al-Ašja ${ }^{(32}{ }^{32}$ said: "You made a promise, but not fulfilling it was in your character (6) Like the promises of "Urqūb to his brother in Yatrib." And from the poem $S u^{\complement} \bar{a} d$ is gone: ${ }^{33}$ (7) "The promises of 'Urqūb were for her a model tall-tale promises, empty talk." They call (8) someone of the night guards 'azab 'bachelor', which has an equivalent, because in the [Classical Arabic] language ' $a z a b$ is "someone who does not (9) have a family", and someone who has a family as a rule does not do this [night] watch, and someone who does not have a wife (10) is also a ' $a z a b$, "and do not say $a^{c} z a b$, or it is rare; the plural is $a^{c} z \bar{a} b$ and the feminine ' $a z a b a$ and ' $a z a b$, (11) and the verb is like nasara; ${ }^{34}$ and ta'azzaba means he abstained from marriage." A curiosity: just like ta'azzaba with a zāy means 'to abstain', (12) so also with a $r \bar{a}$, ${ }^{35}$ because it means that he left his land, and likewise $y a^{c} z i b u$ with the meaning 'to be absent', so the proximity is in both (13) the pronunciation and the

${ }^{32} \mathrm{Abū}$ 'Āmir Ibn Šuhayd al-Ašğa'ī (992-1035) was an Andalusian poet, man of letters, and vizier. See Pellat (2012a).

${ }^{33}$ This is from the lammiyya known as the Burda, by Ka`b b. Zuhayr, a contemporary of the Prophet. See Basset (2012). Translation of this verse by Sells (1990, 149).

${ }^{34}$ I.e., it has the vowels $a-a$, so 'azaba.

${ }^{35}$ I.e., $t a^{c} a z z a b a$ and $t a^{c} a r r a b a$ have the same meaning. 
meaning. It is known that the man is ' $a z a b$ and the woman ' $a z a b a$, not ' $\bar{a} z i b a$ as they say.

\section{Commentary}

This section is divided into two parts: the first will discuss the orthography of the Classical Arabic component of the text, and the second part will focus on the Egyptian Arabic entries.

\section{Classical Arabic: Orthography}

The main body of the text, which consists of al-Magribī's comments on the Egyptian Arabic words under discussion, and contains quotations from al-Qāmūs al-muhịt and other dictionaries, the Qur’ān, hadìth, and poetry, are all in Classical Arabic in terms of morphology, syntax, and vocabulary. However, the orthography is not according to the standards of Classical Arabic, but follows patterns that are well-known from Middle Arabic texts. AlMagribī's biography shows that he was an educated man, who studied at the Azhar University, was interested in the Arabic language, and had good knowledge of dictionaries and other works on linguistics. He also composed poetry in Classical Arabic. This is indicative of his excellent knowledge of the Arabic language. The fact that the orthography he used does not adhere to the standards of Classical Arabic can therefore not be attributed to insufficient knowledge of the language. As Lentin (2011) points out, "many writers have left us works written both in faultless or even sophisticated Classical Arabic and works written in Middle Arabic. For those writers at least, one has to abandon the idea of their inadequacies in Classical Arabic." We have to bear in mind 
that in many text editions, the orthography has been standardised by the editors, and that many Classical Arabic texts originally contained Middle Arabic features (Lentin 2011). In fact, the history of Arabic orthography has not been sufficiently studied yet; in order to do so, more text editions that are faithful to the original orthography need to be published (Den Heijer 2012). As for Daf' al-ișr, the most important orthographic features are highlighted in the sections that follow (see also Zack 2009, 77-83).

\section{The hamza}

The hamza has been omitted in many cases. As the text is in Classical Arabic, this omission of the hamza is unlikely to be indicative of its loss in the pronunciation. Rather, as Blau (2002, 32) suggests, it could reflect "an ancient orthographic habit preserved also through N[eo-]A[rabic] influence."

Some examples of omission of the hamza (see also Blau 2002, 32-33):

initial hamza: اي 16r, ln. 16 (ألاضداد) 16r, ln. 19 (الأضداد).

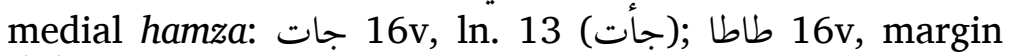
(شأطأ) 17r, ln. 5 (شيئا).

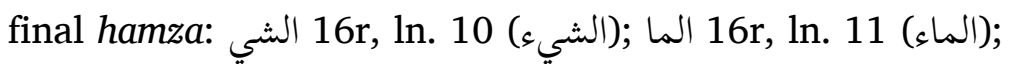
16r, ln. 16 بالطاء).

When the $y \bar{a}^{3}$ is the seat of the hamza, it is written below the $y \bar{a}^{\prime}$, e.g., طآير 16r, ln. 17 (طائر) 17r, ln. 3 سآئل 16). It can also be omitted, as in فابده 16r, ln. 12 (فائدة); 16v, ln. 11 (سائرة).

${ }^{36}$ And other instances; in such cases, only one line number is given here. 


\section{The madda}

The madda is sometimes omitted, e.g., in الان 16r, ln. 20 (الآن.). However, more interesting is that the madda is added on the 'alif

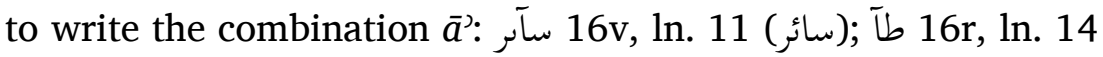
(ط). Often for good measure an extra hamza is added as well:

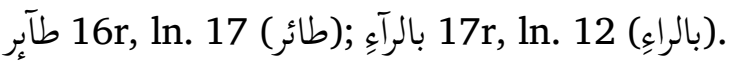

The $y \bar{a}$ ' and 'alif maqșūra

The $y \bar{a}^{\prime}$ and alif maqșüra are often used interchangeably. alif maqsūra instead of $y \bar{a}$ : في 16r, ln. 11; 16r, ln. 13; 16v, ln. 8.

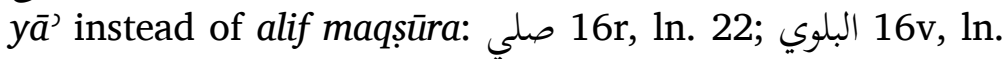
11; 17r, ln. 4; 17r, 1n. 12.

\section{The $t \bar{a}^{3}$ marbūta}

The $t \bar{a}^{3}$ marbüta is often written without dots, even if it is the first part of a genitive construction. Examples: الطابه 16v, margin; 16v, ln. 15; نادره 17r, ln. 11; عزبه 17r, ln. 13.

\section{Egyptian Arabic Lemmata}

tabtab 'to pat': this entry provides a good example for how alMag̀ribī comments on Egyptian Arabic vocabulary. In most cases he does not give a definition of the word under discussion, assuming that his readers know what it means. In Egyptian Arabic, tabtab is used nowadays with the meaning of 'to pat' (Badawi and Hinds 1986, 530b; see also Dozy 1881, 2:21b); the combination with 'alā given by al-Magribī makes it likely that it meant just that in the 17th century, but the quotation from al-Qāmūs almuhit does not give the exact same meaning. The entry also shows 
how al-Maġribī integrates anecdotes about his own acquaintances and events from his own life into the dictionary.

al-țarab 'agitation': as in al-Maġribī's time, in modern Egyptian Arabic it is used to mean only pleasure, not sadness, but more specifically the pleasure derived from listening to singing (Badawi and Hinds 1986, 534a).

$t \bar{a} b$ 'the tâa-game': the game of $t \bar{a} b$ is still played today in Egypt. It is a "game for two players with stone counters and four strips of palm branch, each strip having one green side and one white side; the strips are thrown against a vertical surface and the various combinations of green and white govern the movement of the stones on a grid drawn in the dust" (Badawi and Hinds 1986, 528a). Lane (1863-1893, 55-58) gives a detailed description of the game and how it is played (Zack 2009, 74, 243; see also Dozy 1881, 2:65a-b).

țāwb 'to bow one's head in greeting': no references found in Classical Arabic or Egyptian Arabic dictionaries.

țūb 'bricks': from Coptic $\tau \omega \omega \beta \varepsilon$ 'brick' (Crum 1939, 398a; Badawi and Hinds 1986, 548b). The reason that al-Magiribī does not refer to its non-Arabic origin is that al-Fīrūzābādī (1999, 103a), alMagrribī's main source, does not mention that it is a loanword.

muțāyaba 'joking': as in Classical Arabic (Lane 1863-1893, 1952c).

țābga 'tobacco'. Tobacco was introduced in Egypt in 1603-1604 (Matthee 2012), two years before al-Maġribī wrote Daf' al-iṣr (Zack 2009, 70-71). His comments show how tobacco very rapidly became popular, with special shops and coffee houses where 
customers could smoke being established within the two years of its introduction. Al-Magribī did not view the smoking of tobacco favourably, as he comments on how he tried it and became dizzy and considered it a vice. He returns to the subject of tobacco on fol. $75 \mathrm{v}$, where he mentions that there were discussions about whether it was permissible to smoke tobacco while fasting during Ramadan, with one sheikh ruling that it was indeed allowed. AlMagribi found this reprehensible (he mentions this anecdote in the lemma radil 'depraved'). Badawi and Hinds (1986) do not mention the word tâabga for tobacco, and neither does Spiro (1895). ${ }^{37}$ It is mentioned by Steingass $(1884,162 \mathrm{~b})$ as $t a b \dot{g}$ and by Dozy (1881, 2:141a) as tibg.

' $b b$ 'bosom of a garment'. It still has the same meaning in modern Egyptian Arabic, vocalisation ' $i b b$ (Badawi and Hinds 1986, 558b; ' $u b b$ in Classical Arabic, where it means 'base of the sleeve', as demonstrated in the quotation from al-Fìrūzābādī mentioned by al-Mağribī).

'ataba 'threshold'. According to al-Magribī, this applied only to the lower part of the door frame, but in modern Egyptian Arabic it is both the lower and upper part (Badawi and Hinds 1986, $558 b)$.

'arqab 'to hamstring', i.e., incapacitate by cutting the hamstring tendon. The word is still in use in modern Egyptian Arabic (Badawi and Hinds 1986, 574a).

\footnotetext{
${ }^{37}$ Badawi and Hinds (1986) mention tumbāk / țumbāk (136a, 546b) and duxxān (282a). Spiro (1895) mentions the Turkish tutun (68a) as well as duxxān (194b).
} 
'azab 'member of the night guard': this meaning was derived from the original meaning 'bachelor', because only men who did not have a family would work in the night guard. ${ }^{38}$ Dozy (1881, 2:124a) mentions 'milice bourgeoise'. The 17th-century meaning of 'member of the night guard' disappeared in the 19th century, as it is not mentioned by Spiro (1895, 396b). Badawi and Hinds (1986, 574b-575a) mention only the forms ' $a{ }^{c} z a b$ and ' $\bar{a} z i b$ 'bachelor', not ' $a z a b$, although they do mention the feminine form 'azaba (alongside ' $a z b a<{ }^{\prime} \bar{a} z i b a$ ).

${ }^{38}$ See Cezzâr (1962, 32) for more information on the night guard in Ottoman Egypt. 



\title{
9. LEBANON: CHRONICLE OF AL-ȘAFADĪ (EARLY 17TH CENTURY [?])
}

\author{
Jérôme Lentin
}

In the first annex to their edition of al-Ṣafadī's chronicle (about the period 1612-1624) Bustānī and Rustum (1969, 208-41) published a section dealing specifically with the years (1613-1618) Fahr al-Dīn spent in Italy. For them, al-Ṣafadī (a scholar born in Safad, who studied in Al-'Azhar in Cairo, and the author of learned works as well as of travelogues) is not the author of this text, an opinion which seems reasonable, but is not shared by all scholars.

A recent edition is the 2007 volume Rihlat al-'Amï Fahr alDīn 'ilā 'İtāliyā, 1613-1618. Faḩr al-Dīn al-Ma'nī al-țānī, ḥaqqaqahā wa-qaddama lahā Qāsim Wahb. Beirut: Al-Mu'assasa al-'arabiyya li-l-dirāsāt wa-l-našr and Abu Dhabi: Dār al-Suwaydī li-1-našr wa-l-tawzīi (Irtiyād al-'’âāāq).

\section{Transcription}

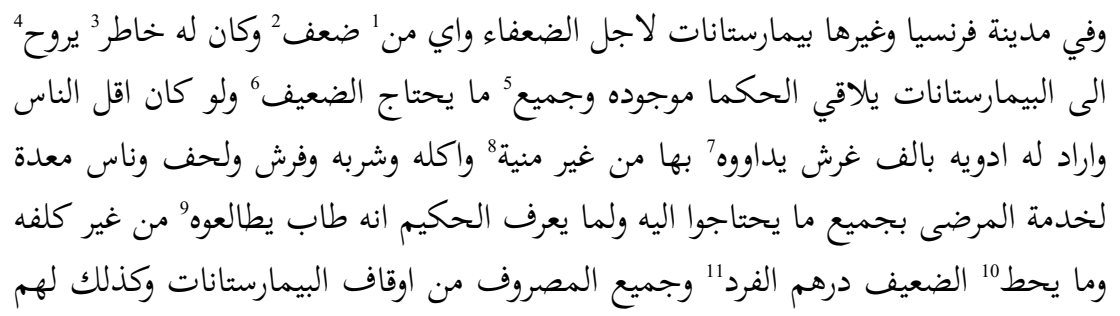




$$
\begin{aligned}
& \text { ديوره فيها خدامين }{ }^{13} \text { ومراضع كلما خلق ولد للنسوان } 14 \text { من الذي } 15 \text { تحت القسط او من }
\end{aligned}
$$

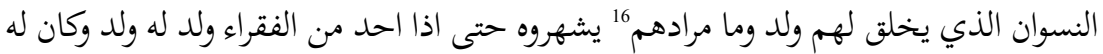

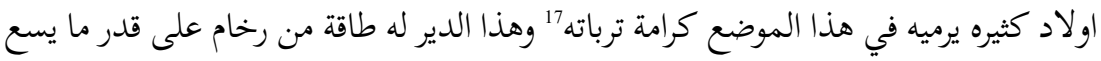

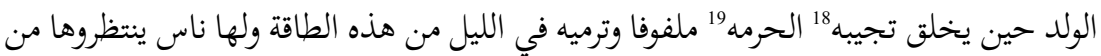

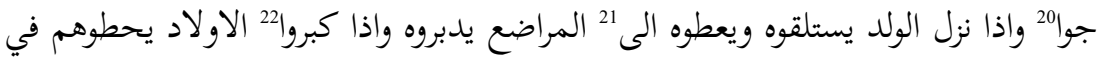

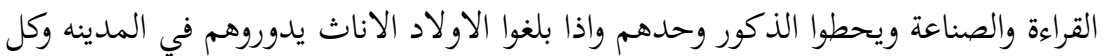

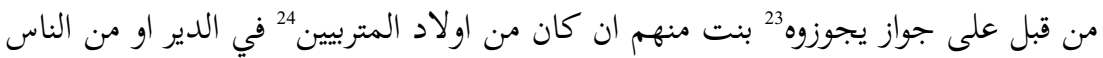

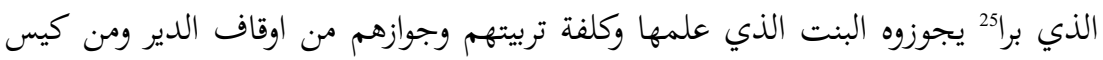

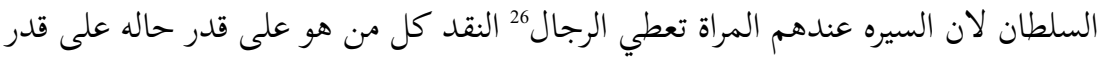

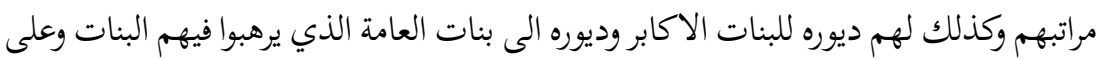

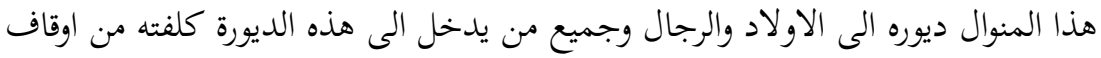

$$
\begin{aligned}
& \text { الدير واولاد الاكابر ياتيهم من اهلئم الاولم ولرجال }
\end{aligned}
$$

\section{Translation}

In the town of Florence, as in others, there are hospitals for ill people. Whoever falls ill and wants to go to the hospital will find there doctors and everything needed by an ill person. Even those with the most limited means, if medicines costing one thousand piasters are necessary, they treat them without any return obligation. They also get food, drink, bed, and blankets. People are there ready to provide all the care patients need. When the doctor sees that the ill person has recovered, they let him out without paying anything: he doesn't pay a single dirham. All these expenses are funded from the endowment income [waqf-s] of the hospitals. They also have monasteries with attendants and wet nurses. Every time a woman of disrepute gives birth to a child, or a woman wants to keep the birth of her child a secret, or even when a poor man with many children has a [new] child, [in all 
these cases] they can leave the child at this place, to have it brought up. This monastery has a marble window the size of a new-born child. The woman brings the baby in swaddling clothes and drops it at night through this window. People are there inside waiting for her and when the baby comes down, they catch it and give it to the wet nurses who take charge of it. When the children grow up, they pay for them to learn to read [and write] and to learn a handicraftbut only the boys. As for the girls, when they reach puberty, they go around the city with them and marry any one of these girls to whoever agrees to do so. Whether it is to one of the children raised in the monastery or to one of the people outside, they give to him as a wife the girl he has singled out. The costs of their upbringing and marriage are covered by the endowment income of the monastery and at the expense of the sultan, because this is their way of doing things: the woman gives to the man the dowry-each according to his situation and to their [respective] rank. They also have monasteries for the daughters of the notables and monasteries for the daughters of the common people, where they turn them into nuns. And the same goes for the monasteries for boys and men. All those who enter the monasteries [in the case of the children of the common people] have their costs paid from the endowment income [waqf-s] of the monastery. As for the children of the notables, they are funded by their families.

\section{Commentary}

1 اي من 'ayman 'whoever' (colloquial).

2 ضعف 'to get sick, to fall ill' (colloquial); compare no. 6. 
3 له + (subjunctive) imperfect 'to want, wish, desire to, to feel like doing sth' (colloquial).

${ }^{4}$ ح rāh (and less frequently rawwah) is the usual verb in MA for 'to go' and 'to go to'. For this last meaning, the more stylistically elevated نوجّه is also widely.

5 + noun / pron. is the most common quantifier in (Levantine) MA for 'all'; 'whole, entire', even before a singular (pro)noun.

6 الضعيف 'ill, sick' (compare no. 2).

7 يداوg. The (colloquial) -ū form (and not -ūn) is used most of the time in MA for the second and third person plural of the imperfect; the -ün form is used either in classicising passages or as a marked form, for instance after final conjunctions (contrary to Classical usage). Compare the many other examples of $-\bar{u}$ forms in this text: يحطوهم ,يدبروه ,يستلقوه ويعطوه رينتظروها ,يطالعوه ,يحتاجوا

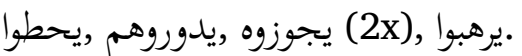

8 منية. Colloquial, see Barthélemy (1935-1969, 804); see also Dozy (1881, vol. II, p. 616).

طالع is used with its colloquial meaning 'to throw out, pull out, remove, dismiss, expel', etc.

10 حط 'to put, place', here figuratively 'to pay (an amount of money)' (colloquial).

11 fard = 'one and only, one and the same'; this construction, $\varnothing+\mathrm{N}$ sing. + art. + فرد + is mainly used after a negation, as is the case here; it can be as a whole modified by the article (الدرهم الفردم: i.e., [الفرهم الفرد). See Lentin (1997, 312). 
12 (ديورا also) is the most frequently used (colloquial) plural of دير 'convent, monastery' in Ottoman MA texts (see Lentin 1997 184-186, §4.3.7.5).

.خدامين. The formerly mpl oblique case sound form -in is predominantly used in MA regardless of the syntactic function of the noun (the $n$ being generally retained in construct state). The Classical nominative -ūn form is reserved for stylistically marked use. انق ولد لـ lit. 'a child is created (born) to...' (colloquial hiliq); compare the following ولد له ولد (speaking of a man).

15 للنسوان من الذي. Invariable الذي is extremely common in MA. Compare الناس الذي بران من النمان.

16 ما مرادهم يشهروه. Most probably a transposition of colloquial ma bidd-hon yišəhrū.

17 ترباته. Colloquial verbal noun of rabbā (tərbāy, tarbāye, etc.).

18 تجيبه $18 \bar{a} b$, yžỉ 'to bring' is probably the most frequently used colloquial verb in MA, and can be considered a typical 'plain MA' verb.

19 الحرمه 'the woman' (colloquial).

20 lit. 'from inside'. Colloquial žuwwā (adverb and preposition, construct state žuwwāt) 'inside' and barrā (barrāt) 'outside' are widely used in MA.

(and ديوره الى بنات العامة (21). The use of الى الى الاولاد والرجال. where either Classical or colloquial Arabic would have J, is typical of a frequent MA procedure whereby a partial correspond- 
ence between a colloquial and a Standard preposition is generalised into total interchangeability (often bringing about a pair of stylistically contrasting variants).

22 كبر 'to get old' (colloquial kibir).

23 .يجوزوه and Colloquial forms (compare Classical Arabic zawāj and zawwaja).

24 مت 24 . is morphologically colloquial (mitrabbyinn). ${ }^{25}$ برا. See no. 20.

الاولاد is the colloquial singular form (rž̌žal), whereas in it is the plural (Classical rijāl, colloquial ržāl). 


\title{
10. A JEW'S TESTIMONY REGARDING A STATEMENT MADE IN HIS PRESENCE BY A MUSLIM, TESTIFIED ON MONDAY 20TH KISLEV 5418 (1657)
}

\author{
Werner Diem
}

\section{Transcription}

אייש חאל (2) ذאטרד עלה יעקב וחק וחק סועוב² עלייה קדר מא (3) סועוב עלה אוכתו ואמראתו ואכתר ופי יום אין גא אל (4) ذבר אין מא עוודשי רוחת נפתש פי נחיית אל בסאתין (5) ואנא ראייח קבלני וואחד מסלם רפיקי בייאע לבן וכונת (6) אנא ויעקב נדذול ונכרוג פי בייתו למא כונא נרום לסוכר (7) פי קאלי אל מסלם אל לבאן יא חג מ"ח אייש דאייר (8) תעמל הנא פי קולתלו מא תערף יעקב רפיקי טלע (9) ליילית אמס ידפן וליידאת ווארח3 ומא עאווד פי קאלי אל (10) לבאן תעאלה מעי נרוחו נפתשו עליה פרוחנא פתשנא (11) ומא לקיינשי פי4 תאני יום גא אל לבאן מחמל באל לבן (12) יביעו הנה פקאלי אנה נצרת אתניין מרמיין מכסרין (13) איידיהום ורגלייהום ואל דם נאזיז מן

${ }^{1}$ Published in Diem (2014, 9-10). Reproduced from the journal Mediterranean Language Review with kind permission of the editor, Prof. Matthias Kappler.

2 סועוב for ${ }^{2} u b$.

3 ווראח for. ווארח

פי 4 here fi- $(<f a-)$. 
רוסהום פי טל פיהום (14) אל לבאן פי ערף יעקב פי קאללי אל לבאן תעאלה מעי (15)

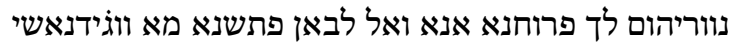

\section{Arabic Transcription}

$$
\begin{aligned}
& \text { اييش حال (2) خاطرك عله يعقب وحق وحق سوعوب علييه قدر ما (3) سوعوب عله اوختو }
\end{aligned}
$$

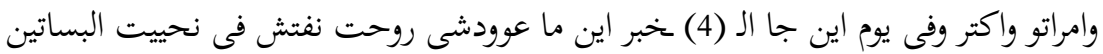

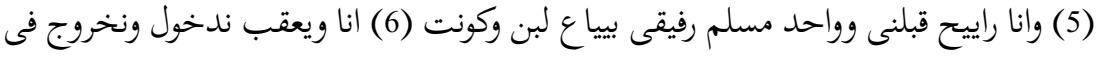

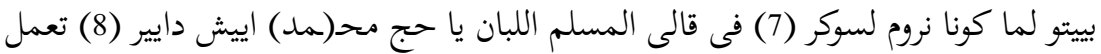

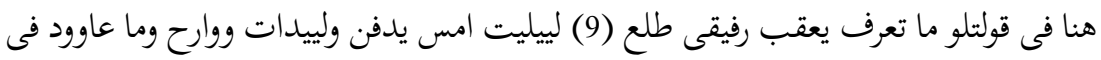

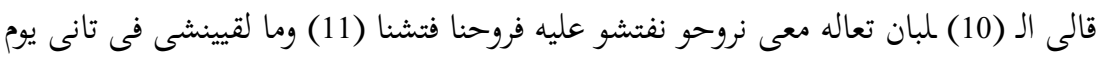

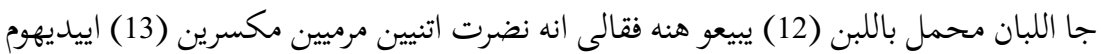

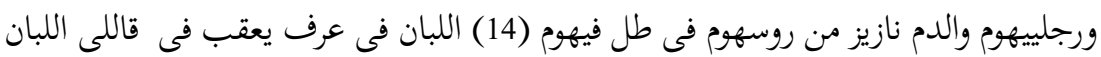

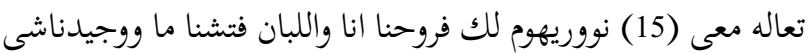

\section{Translation}

What do (2) you think about Jacob? Seriously, I was very sad about him, as (3) were his sister and wife, and even more. On the day when the (4) news reached (us) that he had not returned (home), I went to look (for him) near al-Basātīn. (5) While I was walking, one of the Muslims, a friend of mine, a seller of milk, met me. (6) Jacob and I had frequented his house when we wanted sweets. (7) The Muslim milkman said: "O Hajj Muh(ammad), what are you doing (8) here?" I said to him: “Don't you know that Jacob, my friend, went out (9) yesterday night to bury little girls, he went and did not come back." Then the milkman (10) said to me "Come with me! We'll go and look for him!" So we went to look, (11) but did not find him. On the next day, the milkman came carrying milk (12) in order to sell it here. He 
said to me: "I saw two who had been struck down, with broken (13) hands and feet, and blood oozing from their heads." When the milkman looked down on them, (14) he recognised Jacob. So, he said to me: "Come with me! (15) I will show them to you." Then the milkman and I went to look for them, but we did not find them. 



\title{
11. A JEW'S TESTIMONY REGARDING A STATEMENT MADE IN HIS PRESENCE BY A MUSLIM (1681) ${ }^{1}$
}

\author{
Werner Diem
}

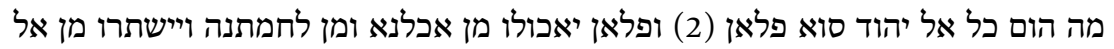

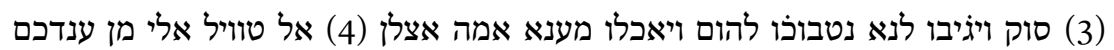

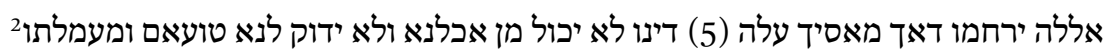

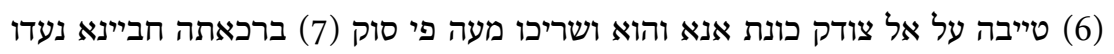

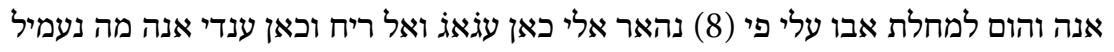

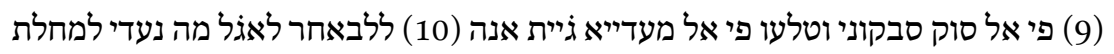

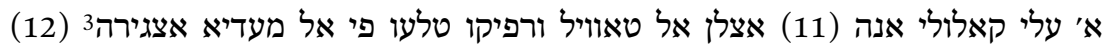

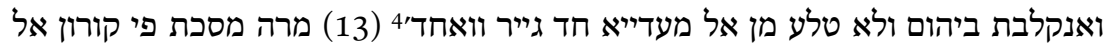
בקרה היא אלי טלעת ביתום וליע

\section{Arabic Transcription}

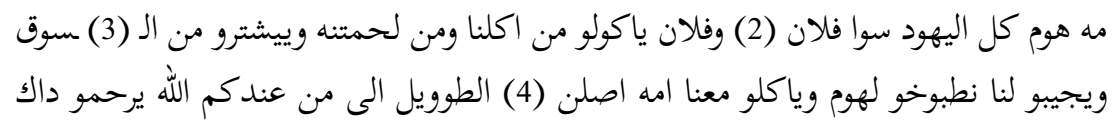

${ }^{1}$ Published in Diem (2014, 22-23). Reproduced from the journal Mediterranean Language Review with kind permission of the editor, Prof. Matthias Kappler.

${ }^{2}$ Based on mu'āmala.

${ }^{3}$ Phonetic spelling instead of אל צגירה.

${ }^{4}$ Feminine form, abbreviated at the end of the line. 
ماسيك عله (5) دينو لا يكول من اكلنا ولا يدوق لنا طوعام ومعملتو (6) طيببه عل الصودق

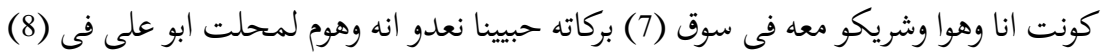

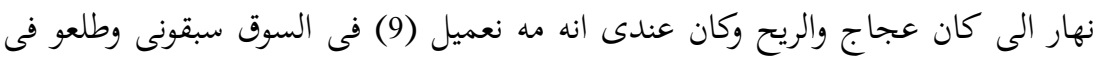

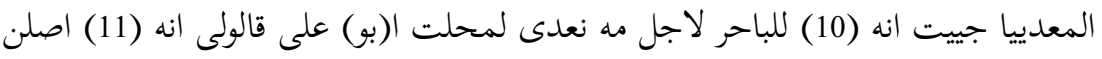

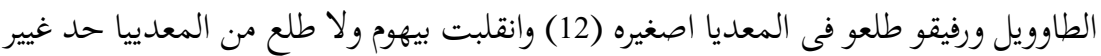
وواحد(ه) (13) مره مسكت فى قورون البقره هيا الى طلعت

\section{Translation}

Not all Jews are alike. So-and-so (2) and so-and-so eat from our food and from our meat, and buy from the (3) market and bring (it) to us so that we cook (it) for them, and they eat together with us. Concerning Aṣlān (4) the Tall, who belongs to you (Jews)may God have mercy on him-he adheres to his (5) religion. He does not eat from our food. He does not taste our dishes. His behaviour is (6) excellent in terms of piety. He and I, and his business partner with him, were at the (7) Sūq Barakātih (market). We, they and I, wanted to cross to Mahallat Abū 'Alī on that (8) day, when there was dust and wind. I had something to do in (9) the market, so they went ahead of me and went on the ferry. (When) I came to (10) the river in order to cross to Mahallat 'Alī, they told me that (11) Aṣlān the Tall and his companion went on the small ferry. (12) It capsized with them on board and no one escaped from the ferry except for a woman, who grabbed on to the horns of the cow, ${ }^{5}$ and she (alone) came out of it.

\footnotetext{
${ }^{5}$ The speaker presupposes the listener's knowledge of a cow that had been in the ferry.
} 


\section{A BASRA PASSOVER HAGGADAH WITH JUDAEO-ARABIC TRANSLATION \\ (CA. 1700)}

Omer Shafran

Location of the manuscript: Jerusalem, The National Library of Israel Ms. Heb. $8^{\circ} 713$ [B 296 ( $\left.\left.8^{\circ} 713\right)\right]$.

\section{Transcription}

Aramaic/Hebrew

הא לחמא עניא די אכלו אבהתנה בארעא

דמצרים כל דכפין יתי וייכול כל דצריך

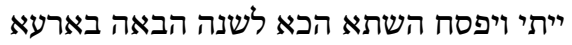
דישרץ השתא הכא עבדי לשנה הבאה בארעא דישרץ בני חורין.

\section{Judaeo-Arabic}

האדא כבז ץ מסכין לֹדי אכלו אבאיינא

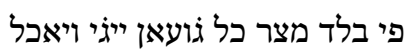
כל מעתאז ייגי וייפסח הסנא נחנא הון לי סנת ל גאייא פי בלד יסראיל הסנא ייפי ויפסח נחנא

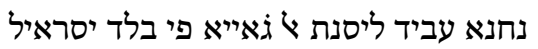
בנין ל מטלוקין. 


\section{Arabic Transcription}

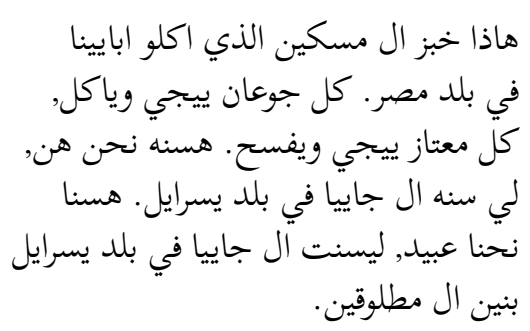

\section{Translation}

'Lo! This is the bread of the afflicted, which our ancestors ate in the land of Egypt; let all those who are hungry enter and eat thereof; and all who are needy, come and celebrate the Passover! This year we are here, but next year we hope to celebrate it in the land of Israel. This year we are slaves here, but next year we hope to be freemen in the land of Israel.' (English translation with slight alterations drawn from Russotto 1912).

\section{Commentary}

The Hebrew/Aramaic influence is obvious in this Judaeo-Arabic passage: the element הסנא has-sana 'this year', is an apocopation of the demonstrative $h \bar{a} \underline{d} i$, as is common on Southern Iraq $\overline{1} .{ }^{1}$ Its use in this context may additionally have been facilitated by the homophonous Hebrew definite article. The verbal form ייפסח yifsah, here 'he will celebrate the Passover', is peculiar to the language of the Jews, and is derived from the festival name Pesah 'Passover'; this verb appears also in the original Aramaic/Hebrew text (see above, יפסח). The structure לי סנת ל גאייא

\footnotetext{
${ }^{1}$ I am grateful to Prof. Clive Holes for this suggestion.
} 
reflects the spoken Arabic of Iraq, where constructions such as sana l-jāya 'next year', bab iš-šārgi 'the eastern gate', and șōb aljanūbi 'the southern direction' are common. ${ }^{2}$ It is an old construction that has disappeared from Modern Standard Arabic, but is still very common in the dialects, and its usage in this place may have been reinforced by its being a calque of the analogous Hebrew construction לשנה הבאה , le-šana (indefinite, thus in this passage) $h a b-b a^{\prime} a$ (definite) 'next year'.

${ }^{2}$ Again, I am indebted to Prof. Clive Holes for his comments on the phenomenon. 



\title{
13. QAHWA 'COFFEE' \\ (16TH-17TH CENTURIES)
}

\author{
Ghayde Ghraowi
}

\section{Transcription}

$$
\text { "قهوة" من دفع الإصر عن كلام أهل مصر للمغربي:1 }
$$

يقولون قهوة للمستخرج من البن وليس في اللغة قال (القهوة الخمرة والشبعة المحمكة واللبن

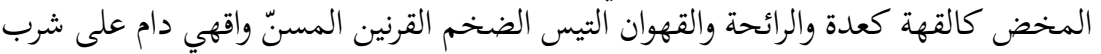

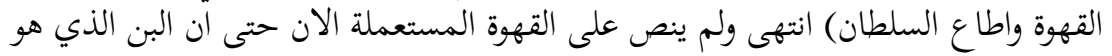

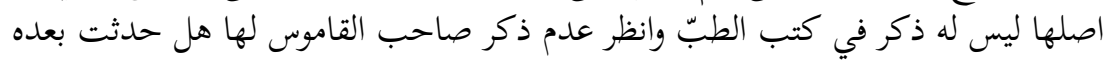

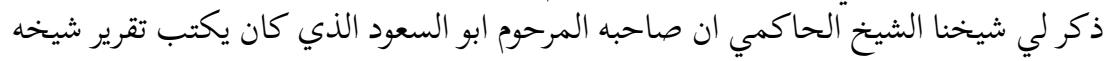

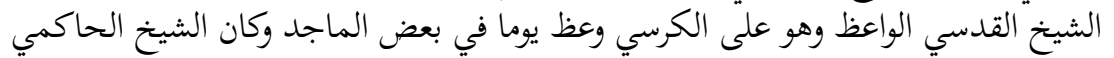

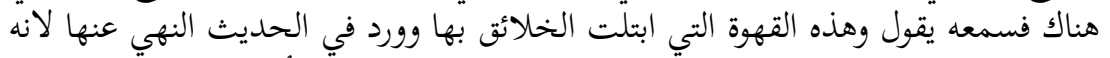

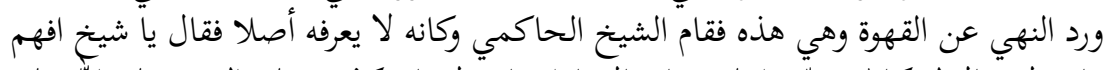

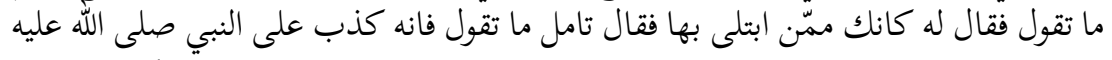

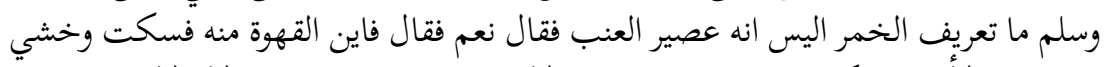

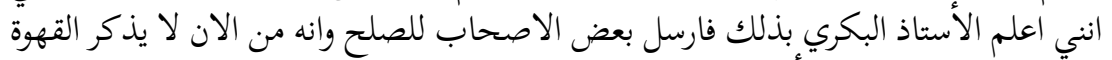

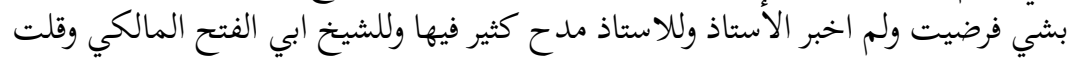

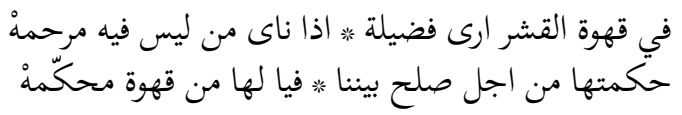

${ }^{1}$ Zack (2009, 202-3). My transcription here follows that of Zack's edition, leaving orthographical particularities from the manuscript source uncorrected. 
شعر قهوة البن لابراهيم ابن المبلط من الكواكب السائرة بأعيان المئة العاشرة للغزي:2

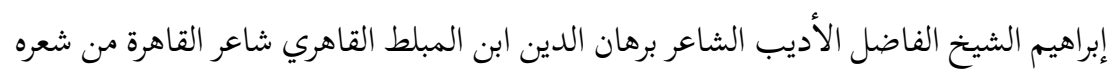

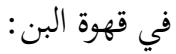

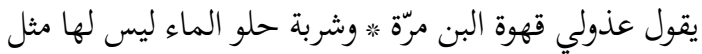

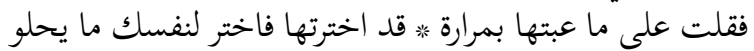

$$
\begin{aligned}
& \text { وقال : وقى البوة في عصرنا * على شربها الناس قد اجمعوا }
\end{aligned}
$$

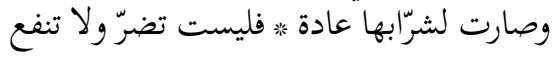

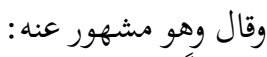

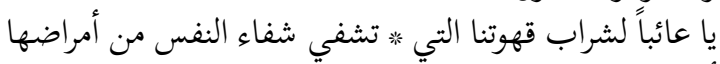

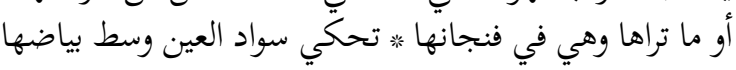

$$
\begin{aligned}
& \text { ولبعضهم في هذا المعنى: }
\end{aligned}
$$

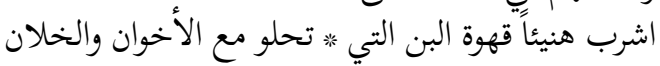

$$
\begin{aligned}
& \text { سوداء في المبيض من فنجانها * تحكي سواد التهاد العين للإنسان } \\
& \text { قلت أحسن منه قولي: }
\end{aligned}
$$

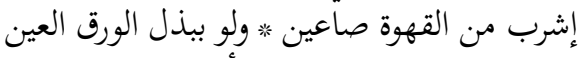

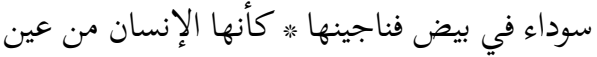

$$
\begin{aligned}
& \text { موشح قهوة البن من ديوان محمد البكري:3 } \\
& \text { أدر القهوة في كأس البها }
\end{aligned}
$$

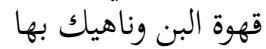

${ }^{2}$ Al-Ghazzī (1979, 3:92-93).

3 Muḥammad al-Bakrī, Dīwān (MS 59 Bibliothèque Nationale du Royaume du Maroc, 1586, fols 99b-100a). It is important to note the coincidence of the manuscript's copy date and the death of its author. Also, the first three stanzas appear in Kīlānī (1965, 194-95). My thanks to Adam Sabra for providing me with the manuscript source. 


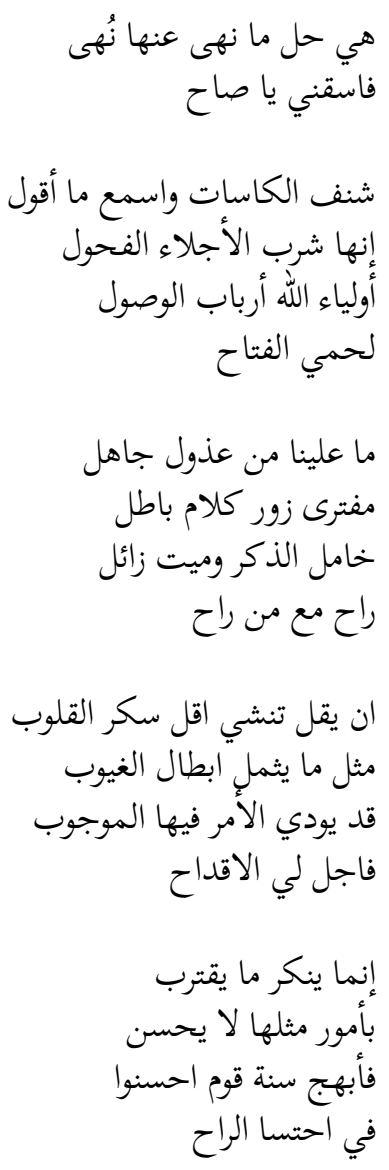

\section{Translation}

'Coffee' from Daf' al-iṣr 'an kalām ahl Miṣr by al-Maghribī:

[The Egyptians] say: coffee (qahwa) for the extract of the bean, but this usage is not in the standardised language [according to 
al-Fayrūzabādī], who says, "qahwa is wine, a thoroughly" satiating drink, and a froth-less, clear ${ }^{5}$ yogurt. It is like qiha/qaha (one of the names of the narcissus) [?] and it is an aroma. The word qahwān means a large aged goat with two horns. The verb $a q h i^{6}$ means to persist in drinking qahwa and to obey the sovereign." These definitions don't indicate coffee used today, and even the bean, which is its source, has no mention in the medical textbooks, so bear in mind their lack of mention by the author of alQāmūs-did it occur after him? Shaykh al-Hâakimī ${ }^{7}$ gave me an account of his deceased companion, Abū al-Ṣa_tūd, ${ }^{8}$ who was writing down the statements of his master, the preacher Shaykh alQudsī one day when he was preaching in one of the mosques. ${ }^{9}$ Shaykh al-Hākimī was there, and heard him say, "Coffee (qahwa) is that with which the people are afflicted, and its prohibition appears in the Hadith. This is so because of the prohibition against qahwa (i.e., khamr)." Then Shaykh al-Ḥākimī stood as if he did not know this already, and said, "O Shaykh, take note of what you're saying." So, Shaykh al-Qudsī said to him, "It is as though you are of those who are afflicted by qahwa." So, alHâakimī replied, "Contemplate what you are saying." And because

${ }^{4}$ While the original reads muhmaka, this is likely an error on al-Maghribï's part, as the edition of al-Qāmūs al-muhit shows muhkama. See al-Shami and Ahmad (2008, 1378).

${ }^{5}$ Makhd (sic - read mahd).

${ }^{6}$ Sic - read aqhā.

${ }^{7}$ As in Zack's study, this figure remains unidentified.

${ }^{8}$ As in Zack's study, this figure remains unidentified.

${ }^{9}$ Mājid (sic - read masājid). 
it seemed that he was lying about the Prophet [he added,] "What is the definition of wine (khamr)? Is it not the juice of grapes?" Shaykh al-Qudsī said, "Yes." So, al-Ḥākimī said, "So, where does coffee fit in this?" He was then speechless and feared that I would inform al-Ustādh al-Bakrīin ${ }^{10}$ of this. So, he sent some companions to make peace over the matter, and to this day he doesn't mention coffee in anything. So, I was pleased, and didn't inform alUstādh [al-Bakrī], who has many poems in praise of coffee-as does Shaykh Abū al-Fath al-Mālikī. ${ }^{11}$ I wrote the following:

I witnessed a virtue in the coffee husk

when he who is without compassion is far

I judged it fairly to make peace between us

as this virtue from coffee is a just arbiter

Entry for Ibrāhīm ibn al-Muballaṭ from al-Kawākib al-sā’ira bia'yān al-mi'a al-'āshira by Najm al-Dīn al-Ghazzì:

The Eminent Shaykh, litterateur, poet Ibrāhīm Burhān al-Dīn ibn al-Muballaṭ al-Qāhirī, poet of Cairo. The following comes from his poetry on the coffee bean:

My critic says, "coffee is a bitter drink

water is the sweet beverage without equal"

So, I replied, "what you disparage with bitterness

I've chosen-So, chose for yourself that which is sweet"

\footnotetext{
${ }^{10}$ Given the prominence of the Bakrī family during this period it is difficult to ascertain to which member this reference is made. Al-Maghribì died nearly a quarter century after Muhammad al-Bakrī, author of the below mentioned_muwashshah. It is possible but improbable that al-Maghribī's reference is being made to the same al-Bakrī.

${ }^{11}$ Muftī and poet who lived in Damascus, died 1567/8.
} 
He has also said:

These days, I see the coffee bean

is what people have agreed upon drinking

Drinking it became a custom

it neither hurts nor helps

He is also noted for these lines:

$\mathrm{O}$ critic of the imbibing of our coffee which cures the soul of what ails it

Or you do not see it, when in its cup

it speaks the eye amidst its white

Another poet has a verse with the same motif:

Drink, savoring the coffee bean

that is sweet with brothers and friends

A blackness within the whiteness of the cup

speaks of the man's eyeball

I [al-Ghazzī] have said even better than this, here:

Drink two cups of coffee

even if it costs an extra coin, silver or gold

A blackness in the white of its cups

as though they were of the man's eyes

Coffee Muwashshah from the Dīwān of Muhammad al-Bakrī: ${ }^{12}$

Pass the coffee in the glass at hand

of the coffee bean, how excellent, how grand

What sound reason considers contraband

\footnotetext{
${ }^{12}$ For commentary on the first three stanzas of this muwashshah see Larkin $(2006,231)$. Note my translation here departs selectively from the literal text in order to retain the rhyme scheme of the poem.
} 
So, friend, for me have a drink poured

Adorn the cups, hear what I disperse it's the drink of the masters of verse Allah's privileged, endowed with his forthcoming force for the protection of the lord

Upon us is an ignorant censor who with invalid speech is a lie dispenser a fleeting death, a memory obscure he has gone with wine, poured

It's said at the slightest drink hearts grow intoxicated just as the brave of the unseen get inebriated the matter now finished, the hearts morally obligated But surely, the glasses I've scored.

Though he denies what he nears there's nothing better than these frontiers people's most joyous practice, they're the best, it appears, at drawing out the wine, poured.

\section{Commentary}

The role of coffee in early modern Ottoman society has been addressed from many historiographical perspectives, from its importance as a traded commodity to the religious-legal debates surrounding its illicit status in Islamic law. What is less understood, perhaps, is the intellectual and literary impact of coffee. Presented here are three samples from the linguistic and literary corpus of 16th- and 17th-century Ottoman Arabic. First, an abridged version of Yūsuf al-Maghribī's (d. 1019/1610), entry on 
coffee (qahwa) in his dictionary of colloquial Egyptian Arabic, followed by a few verses of coffee poetry from Najm al-Dīn alGhazzī's (d. 1060/1650) centenary biographical dictionary. Lastly, a muwashshah (strophic poem) by Muhammad al-Bakrī (d. 994/1586), in which the subject of coffee merges into that of wine, demonstrating the generic link in between the two substances in Arabic literature. While these samples have primarily been translated here for readers' enjoyment, they also invite us to think of coffee as a linguistic and literary problematic during the Ottoman period. 


\title{
14. EGYPT: DAMURDĀŠİ'S CHRONICLE OF EGYPT (FIRST HALF OF 18TH CENTURY)
}

\author{
Jérôme Lentin
}

Chronicle of al-'amīr 'Ahmmad al-Damurdāšì (middle of the 18th century), Al-durra al-muṣāna fí 'ahbār al-kināna (manuscript: British Museum OPB MSS OR 173, copied by Mihâ̄ìl Ṣabbāg̀, Ms pp. 218-19; ed. Crecelius and 'Abd al-Wahhāb 1991, 198; ed. 'Abd al-Rahīm 1989, 121-22) ${ }^{1}$

\section{Transcription}

وبنرجع ' الى عبدين باشا اخر سنتهُ سعوا له فى عبد الله افندي الروزنامجي فاراد قتله

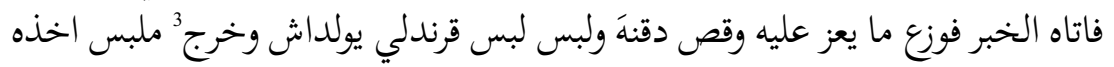

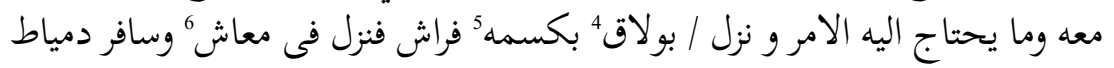

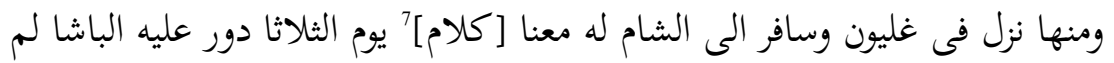

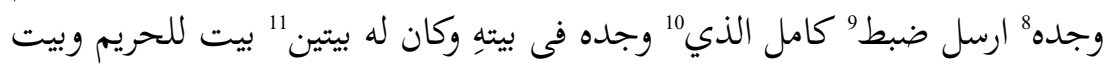

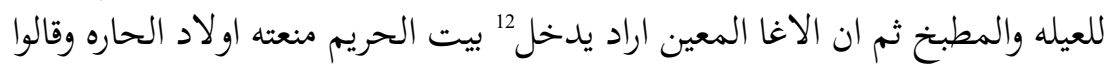

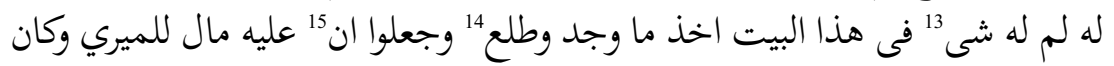

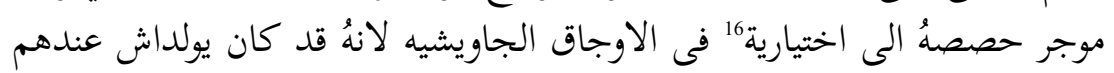

${ }^{1}$ For images see https://ia801308.us.archive.org/zipview.php?zip=/ 21/items/M-0004/09794-.zip: 114/الدرة الدصانة.tif (pp. 217-18); 115/المصانة.tif (pp. 219-20). 


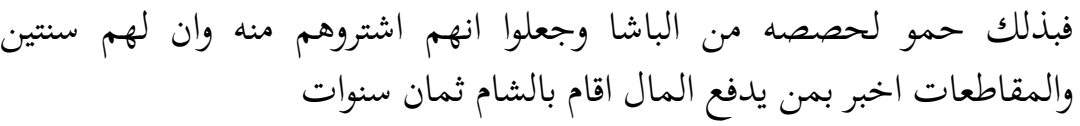

\section{Translation}

(Crecelius and 'Abd al-Wahhab Bakr 1991, 199)

Let us come back to 'Abdīn Bāšā. At the end of his year [as governor], some people worked to set him against 'Abdallah 'Afandī the rūznāmji (executive director of the Treasury) and he planned to kill him. But this latter got informed. He distributed the possessions dear to him, cut his beard, dressed up as a Kalandar dervish [qarandali yūldāš], took a saddlebag where he put clothes and things he could need, and went to Būlāq disguised as a servant. He embarked on a germe boat and sailed to Damietta, from where he embarked on a galleon to Syria. We will come back to him later. On Tuesday, he [ = 'Abdīn Bāšā] searched for him but he could not find him. He ordered that everything that could be found in his house be seized. He [ = 'Abdallah 'Afandī] had two houses, one for his women, and one for his servants and the kitchen. When the appointed ' $\bar{a} \dot{g} \bar{a}$ wanted to enter the house of the women, the people of the quarter prevented him, saying: "He has nothing in this house." The ' $\bar{a} \dot{g} \bar{a}$ [just] confiscated what he had found and left. They [ = 'Abdallah 'Afandī's friends] claimed that he owed money to the land administration and that he had rented his shares to the elders [commanding officers] of the Jawišiyya unit since he was their fellow. By doing that, they protected his shares from the Pasha. They pretended that they had bought them from him two years earlier, and that the renting- 
contracts are the best source of information on who pays. 'Abdallah 'Afandī lived in Damascus for eight years.

\section{Commentary}

${ }^{1} b$ - has inexplicably been omitted in the two editions.

سنته 2 . For damma in \& representing the vowel [u] or [o] of the $3 \mathrm{~ms}$ suffixed pronoun, see Lentin (2012, §3.9, 225-26).

خرج 'saddleback' (classical ḩurj, colloquial ḩərəž).

نزل بولاق In Egyptian MA texts, verbs of movement often take a direct object (as they do in colloquial); cf. سافر دمياط (but note سافر

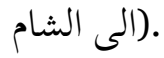

كسم 'clothes, dress' (colloquial).

6 معاش a kind of (small) boat.

${ }^{7}$ [كلام is rightly restored by the editors. This expression is frequently used in the text, as is also common in 'popular' literature, especially in the siras.

8 لم وجده On lam used with the suffix conjugation, see Lentin (1997, 764-67).

9 .رسل ضبط Similar to $b a^{c} a t a / b a^{c} a t$, the verb 'arsal(a) often functions as a factitive auxiliary (see Lentin 1997, §14.5.1, 633-36); the auxiliary verb is generally in the perfect.

10 كامل الذي وجده. In Egyptian MA texts, كامل is the most common quantifier for 'all, whole, entire', even before a singular (pro)noun, as is the case here. It is the exact equivalent of Levantine MA جميع (see text II.9, no. 5).

11 كان له بيتين. The former oblique case of the dual form -ayn/ -e $\bar{n}$ is the dominant form used in MA, regardless of the syntactic function of the noun (exactly like -in in the sound mpl form, see text II.9, no. 13). 
12 .اراد يدخل. Modal auxiliaries are very often asyndetically constructed in MA texts.

13 . For lam negating some types of nominal clauses see Lentin $(1997,782)$.

${ }^{14}$ The colloquial verb طلع is the normal (Near Eastern) MA verb for 'to walk out, go away, leave'.

15 جعلوا ان. For the meaning 'to claim, pretend to', see Dozy (1881, I 198).

16 اختيار Plural of اختيارية. 'old man, senior'.

17 لهم سنتين. Colloquial turn of phrase indicating duration: prep. $l(a)-+$ pers. pron. + noun indicating a period of time + predicative clause 'he... for a (two, three...) year(s)/month(s)'. 


\title{
15. MATENADARAN COLLECTION MS NO.1751: A MEDICAL WORK (1726)
}

\author{
Ani Avetisyan
}

\section{Transcription}

(1) באסם אללה אל רחמאן אל רחים ומא תופיקי אלא איאה יקול אל עבד אל פקיר אלי אלאה אל ואחד אל בארי. (2) מחמד אבן אבראהים אבן סאעד אל אנצארי עאמלה אללה בלטפה "אל חמד ללאה. (3) מנור אל אלבאב ומלהם אל צואב" ובעד פהדא מכתצר ישתמל עלי עלם אל פצד ועמלה. (4) ומא יתצל בה סמיתה נהאית אל קצד פ'י צנאעת אל פצד ורתבתה עלי באבין. (5) "אל באב אל אול פי מא יגרי מן הדי אל צנאעה מגרי אל גזאיאת 1 ואל כליאת והו עשרון פצלא פי חד אל פצד. (6) וכיפיתה ושרוטה ומנאפעה ומא יתעלק בדאלף יתצל בה" אל באב אל תאני פי מא יגרי מן הדי אל צנאעה. (7) מגרי אל גזייאת והו דכר כל ואחד מן אל ערוק אל מקצודה עלי אנפראדה וכיפית פצדה ומנאפעה. (8) ומא יחדר מן כטאה יתופק פיה ואללה אסאלף אן ינפע בה. (9) "אל באב אל אול פי מא יגרי מגרי אל גוייאת ואל כליאת והו עשרון פצלא". (10) אל פצל אל אול פי חד אל פצד הו תפרק אתצאל אראדי יתבעה אסתפראגִ עלי מן אל ערוק. (11) אל פצל אל תאני פי כיפיתה ודאלף הו אן יחס אל ערק קבל אל שד. (12) לינצר חאל אל שראיין פיבתעד ענהא לאנהא לא תצהר בעד אל שד. (13) תם ירבט אעלא מוצע אל עצד רבטא מעתדלא וימלא אל ערוק באל אבהאם ליצהר ויחס באל סבאבה. (14) ליחקק מוצעה ויקיד באבהאם אל יד אל יסרי ליואמן חרכתה תחת אל מבצע. (15) תם יחדת עלי מקדאר גִור אל ערק וירסל אל מבצע בחסבה גִמזא. (16) ויקף וקפה וינצר הל אצאב אל ערק פינתר

1 Two different spellings of the word جزيئات appear in the passage; i גזייאת/גזאיאת which could be a consequence of a copying mistake. 
אל מבצע ליוסע אל פתחה בקדר אל גִרץ. (17) ואן לם יכון אצאב אל ערק סל אל מבצע

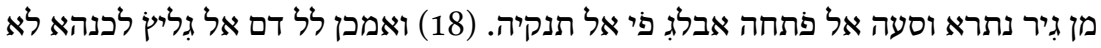
שד סל סריעא ויכשי מנהא אל גְשי ואל טול ובטי אל אלתחאם. (19) ולא יצלח לל ערוק אל דקיקה ואל ערצי סריע אל אלתחאם ויכרה לל דקיקה כוף בתרהא ואל מורב. (20) אופק ואעדל ואדא שד ערק ערק פי אל יד ולם יצהר חל רבאטה ואעיד מרארא ויעלק באל יד שי תקיל ליצהר אל ערק.

\section{Arabic Transcription}

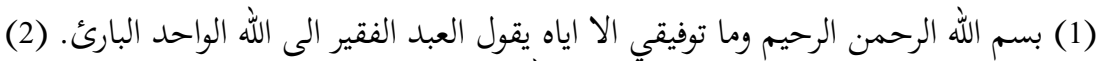

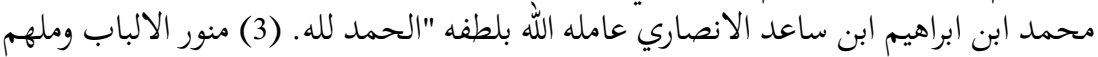

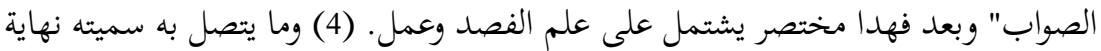

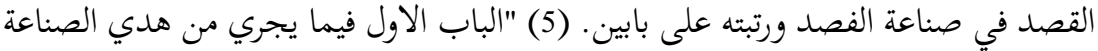

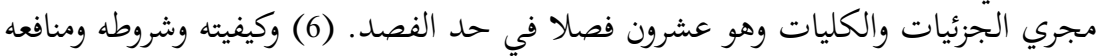

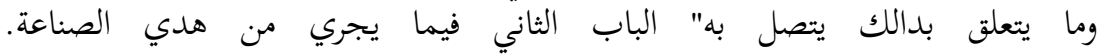

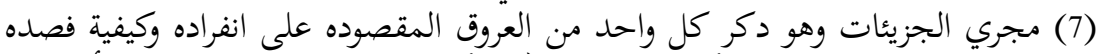

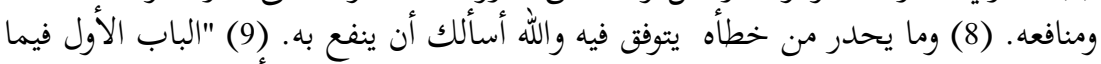

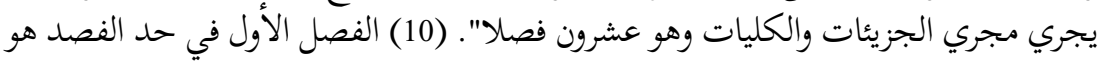

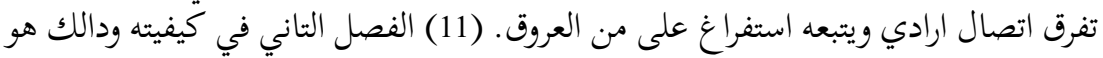

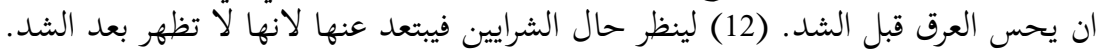

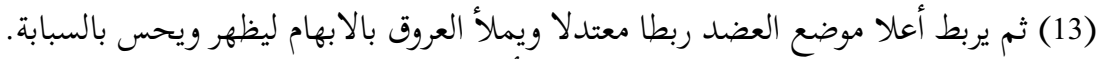

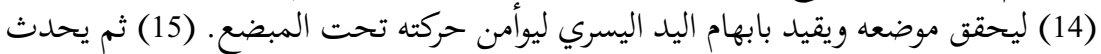

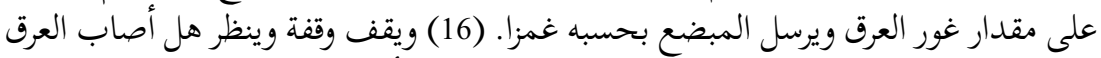

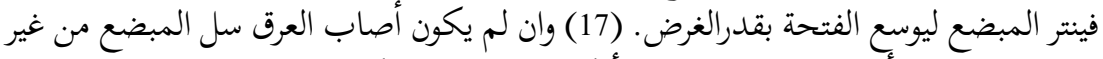

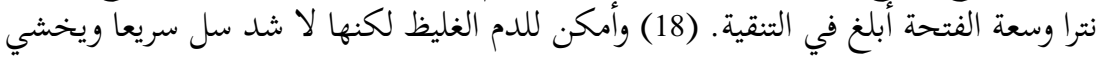

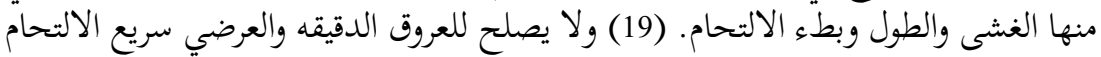

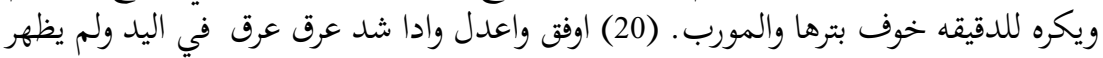
حل رباطه واعيد مرارا ويعلق باليد شي ثقيل ليظهيل ليظهر العرق.

\section{Translation}

(1) "In the name of God, the Merciful, the Compassionate" and my good fortune is only Him, recites the poor self to the One God. 
(2) Muḥammad ibn Ibrahim ibn Sacid al-Anșari, May God, treat him with kindness. (3) Praise be to God, the one who enlightens the hearts and inspires the righteous ones. This compendium contains the science of phlebotomy and its uses. (4) As for the practice of phlebotomy, I called it "The end of search in the art of phlebotomy" and divided it into two volumes. (5) The first volume concerns procedure with regard to the details and generalities of this art. It consists of twenty chapters concerning the manner, (6) conditions, rules and benefit of phlebotomy, and what is related to its practice. The second chapter concerns the details of this art (7) and mentions each individual vein separately, with characteristics of its phlebotomy and benefits. (8) It warns against mistakes that may occur. God, I ask you that there may be benefit in it. (9) The first chapter is concerned what transpires with regard to the details and generalities, and it consists of twenty chapters. (10) The first chapter concerns the manner of phlebotomy, focussing on the separation of voluntary joining, followed by draining of the veins. (11) The second chapter is on its characteristics, and that is to feel the vein before the binding, (12) in order to see the condition of the arteries; and to stay away from them, as they are not discernible after the binding. (13) Then the upper part of the humerus is bound with a moderate tie, veins are filled up (using) the thumbs to become visible and be felt with the forefinger (14) in order to establish its place, and it should be bound with the thumb of the left hand in order to avoid it moving under the scalpel. (15) Then it should be extended, corresponding to the depth of the vein and the scalpel is pointed according to the touch. (16) It should remain in place 
and it should become apparent whether it hits the vein. The scalpel should be inserted to widen the opening as much as intended. (17) And if it does not hit the vein, remove the scalpel without pulling apart the wideness of the opening to facilitate cleanliness (18) and allow the blood to clot, because it does not heal quickly, and from it can occur unconsciousness, prolongation, and slowness of closing. ${ }^{2}$ (19) Fast closing is not suitable for the thin and horizontal veins. It should be detested for thin ones for fear that they might be cut off and tightened. (20) Make it suitable and balance it, and if the vein becomes thick in the hand and the loosening of the binding has not made it become apparent, repeat it several times; and suspend something heavy from the hand in order for the vein to appear.

\section{Commentary}

The late Judaeo-Arabic medical treatise Nihāyat al-qașd fi șinā'at al-faș (henceforth NQSF) of MS No.1751 is written in a register close to Classical Arabic, despite the lateness of the text.

It exhibits regular occurrences of the Classical Arabic demonstratives $h \bar{a} \underline{d} \bar{a}$ and $\underline{d} \bar{a} l i k a$. The vernacular pronoun $h \bar{a} \underline{d} i$ is rare, but also employed in the text (line 5 ). ${ }^{3}$

\footnotetext{
${ }^{2}$ Or 'Allow the blood to clot, however, it does not heal quickly; there is a fear that there would be unconsciousness, prolongation, and slowness وأمكن للدم of closing' according to the earlier Arabic version of the text الغليظ لكنها لا تندمل سريعا ويخشي منها الغشى والطول وبطء الالتحام.

${ }^{3}$ As Wagner $(2010,75)$ has argued, this may reflect Modern Egyptian Arabic di + the presentative prefix hā. It is worth mentioning, that two different spellings of hādi; האדי, הדי are found in the text.
} 
In NQSF the numerals composed of single digits and tens adhere to the rules of the Classical Arabic; (i) they are followed by the accusative singular and (ii) have a single-digit numeral in gender polarity to the counted noun (lines 5, 9). Numerals almost exclusively appear fully written. 



\section{A CLERICAL LETTER BY RAFAEL AL-ṬŪK̄I FROM THE PRIZE PAPERS COLLECTIONS (1758) ${ }^{1}$}

Esther-Miriam Wagner and Mohamed Ahmed

\section{Transcription}

Envelope

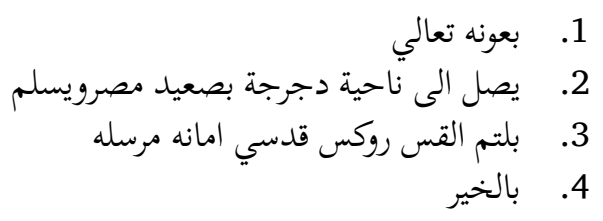

Recto

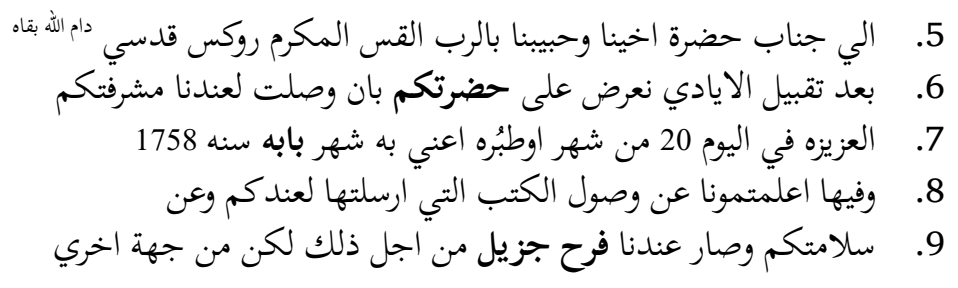

${ }^{1}$ The letter is part of the box HCA 32/212 in the National Archives. Analyses of this letter were previously included in the linguistic description in Wagner and Ahmed (2017). At the time, the authors gave this letter the siglum NAL 46.5, as the letters had not yet been catalogued by the National Archives. 


$$
\begin{aligned}
& \text { 10. صعب علينا موت اخينا المرحوم القس عوض رحمة الله وعزاكم فيه }
\end{aligned}
$$

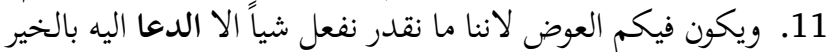

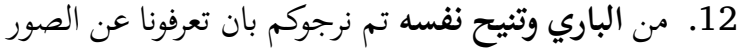

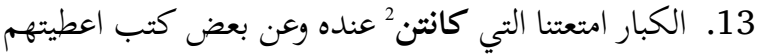

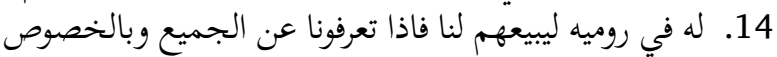

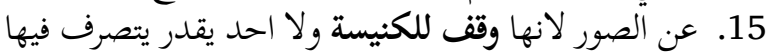

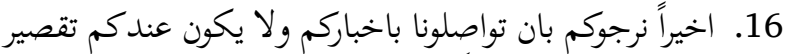

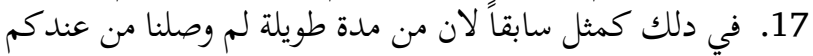

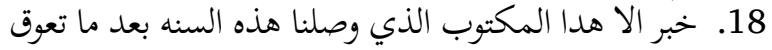

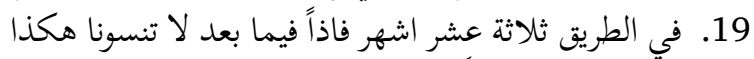

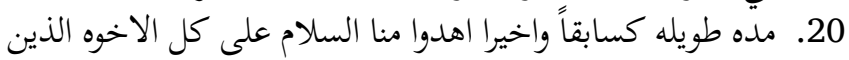

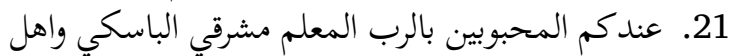

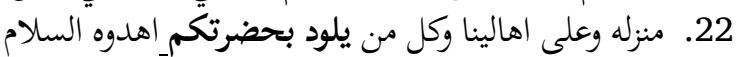

\section{Signature}

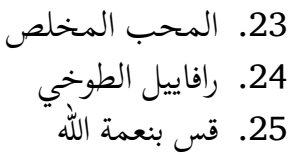

\section{Date}

$$
\begin{aligned}
& \text { 26. سط في } 22 \text { هتور (نوفمبر) } \\
& \text { 27. سنه } 1758 \\
& \text { 28. مسيحية }
\end{aligned}
$$

\section{Translation}

[Written in the hand of Yūhannā Marqūryūs al-Farārjī]

\section{Envelope}

1. With the help of God.

\footnotetext{
${ }^{2}$ Why the nūn was added to this form is not quite clear.
} 
2. (The letter) should arrive to Girga in Upper Egypt, and be delivered

3. into the fingertips of the priest Rūks (?) Qudsì by care of the messenger.

4. In wellness.

\section{Recto}

(5) To the Excellency, our brother and beloved in God, the honourable priest Rūks Qudsī-may God prolong his life. (6) After kissing hands, we acknowledge to your respected self that your precious letter reached us (7) on the 20th of the month Ottobre, i.e., the month Baba, in the year 1758, (8) in which you inform us about the arrival of the books that I sent to you, and about (9) your safety, and we were greatly content to hear that. But on the other hand, (10) we were sorry about the death of our brother, the deceased priest 'Awad-My God's mercy be upon him, and may God give you consolation (11) and may there be recompense for you, because we cannot offer anything but prayers for him and his welfare (12) from the Creator and peace for his soul. Then we would like to ask you to inform us about the large (13) paintings that belong to us that were in his keeping and about some other books we gave to him (14) in Rome to sell on our behalf. So, please inform us about everything, especially (15) about the paintings, because they belong to the Church's charitable organisation (waqf) and no one has the right to dispose of them. (16) Finally, we wish you to keep in touch and not delay in (17) doing as you did previously, because for a long time we have received nothing (18) from you but this letter, which reached us this year 
after a thirteen-month (19) delay. From now on, please do not forget us for such a long period again. (20) Finally, send our greetings to all the brothers who (21) are with you, the beloved in God; the Master Mushraqī al-Bāskī and his family; (22) and to our relatives and to all who are under your protection send our greetings,

\section{Signature}

23. Your sincere friend

24. Rafael al-Ṭūk̄i

25. a priest by God's grace

\section{Date}

26. written on 22nd Hathor

27. of the year 1758

28. of the Lord

\section{Commentary}

There is a marked difference in register within the corpus of Arabic Prize Papers between letters written by merchants and those written by clerics. The clerical letters overall show more literary forms, such as the future particle $s a$ - and much-increased use of the negation particle lam. These forms are used as stylistic markers of the clerical register and were probably introduced through exposure of the clerics to literary Arabic texts, which led to the development of a particular clerical register. 
At the same time, vernacular, non-literary forms occur in particular sociolinguistic circumstances and we also find phonological and morphological Middle Arabic forms similar to those found in the traders' correspondence.

\section{Line 7}

الدعا 'prayer'. As in most Middle Arabic texts, hamza is not spelled. Line 13

من من مدة طويلة لم وصلنا من عندكم خبر 'for a long time, no news reached us from you'. The negation particle lam is a register marker in various Middle Arabic varieties. ${ }^{3}$ In the clerical Prize Paper letters, as in many other Middle Arabic texts, lam has considerably enlarged its functions, and occurs with the perfect, in contradiction to Classical Arabic grammar.

With the imperfect, lam negates the present and with the perfect, past tense forms. The use of lam appears to be related to register in the Prize papers, with clerical writers much more likely to use it than mercantile authors.

\section{Line 15}

13 months'. In most of the Arabic Prize papers under HCA 32/212, there is little marking of the Standard Arabic interdental fricatives $/ \underline{d} /$ and $/ \mathrm{t} /$, and they are usually spelled as $d \bar{a} l$ and $t \bar{a}^{\prime}$. The writer of the letter, Rafael al-Ṭu $\mathbf{k} \underline{i}$, is an exception in his use of marking / $\mathrm{t} /$ with three dots.

${ }^{3}$ For an extensive discussion of lam in spoken and written varieties of Arabic, see Wagner (2010, 141-50). 



\section{A CHRISTIAN MERCANTILE LETTER FROM THE PRIZE PAPERS COLLECTIONS $(1759)^{1}$}

Esther-Miriam Wagner and Mohamed Ahmed

\section{Transcription}

Envelope

$$
\begin{aligned}
& \text { 1. } \\
& \text { 2. يصل الي محروسة مصر يسلم ليد الأخ العزيز الخواجه ديمتري خير } \\
& \text { 3. }
\end{aligned}
$$

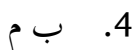

\section{Recto}

$$
\begin{aligned}
& \text { 5. الي جناب الاخ العزيز الخواجه ديمتري المكرم دام الله بقاه }
\end{aligned}
$$

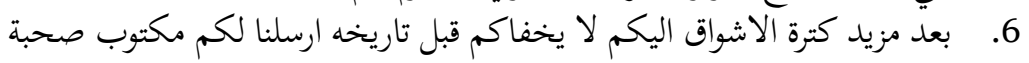

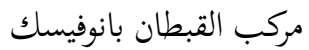

$$
\begin{aligned}
& \text { 7. راكوزي جواب مكاتيبكم انشالله تكونوا اتطلعتوا عليه بخير واخبرناكم بوصول اربعة } \\
& \text { بالاة }
\end{aligned}
$$

\footnotetext{
${ }^{1}$ The letter is part of the box HCA 32/212 in the National Archives. In the analyses for the Prize Papers project, this letter was given the provisional NAL 45.6, as the letters had not yet been catalogued by the National Archives.
} 
8. عصفر وبالتين شمع وستة فروق بن الذين ارسلتوهم من حسابنا علي طريق دمياط 9.

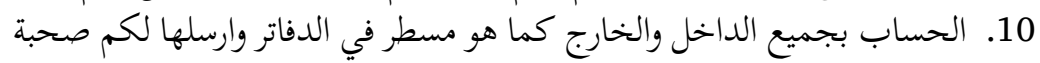

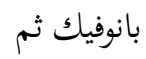

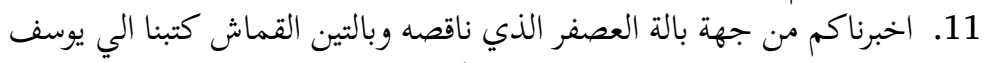

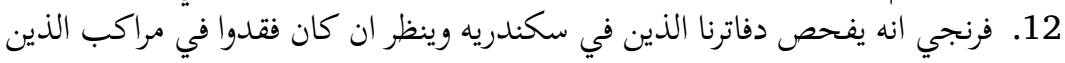
ضاعواً

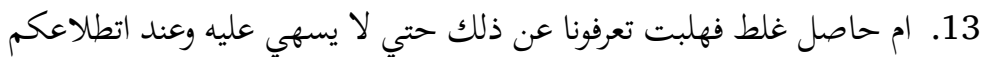

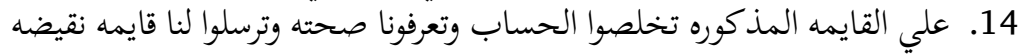

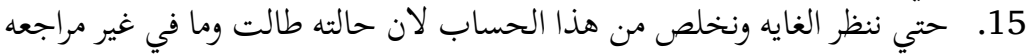

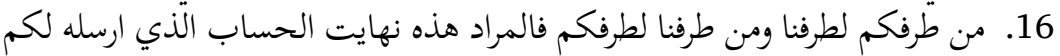

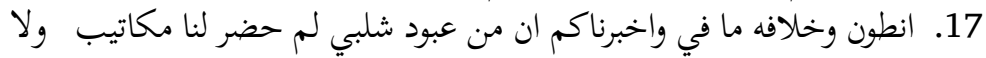
18. عندنا خبر كيف مراده في هذه الحجار انساره الذين ارسلتوهم فالمرجوا

\section{Signature Bottom Left}

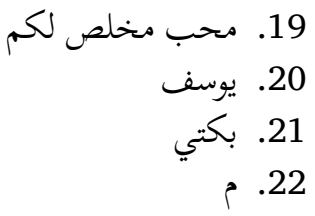

\section{End Right Margin (Date)}

$$
\begin{aligned}
& \text { 23. سنه } 1759 \text { في } \\
& \text { 24. } 16 \text { شهر كانون } \\
& \text { 25. اخرغ }
\end{aligned}
$$

\section{Right Margin}

$$
\begin{aligned}
& \text { 26. يا اخي في حال وصول هذا المكتوب لكم ترسلوا } \\
& \text { 27. له مكتوب وتي وتعرفوه يرسل لنا جوراب هذاب ويعرفنا }
\end{aligned}
$$

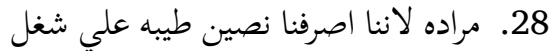

$$
\begin{aligned}
& \text { 29. هذه الحجاره وتركيبهم وهي معطله علينا }
\end{aligned}
$$




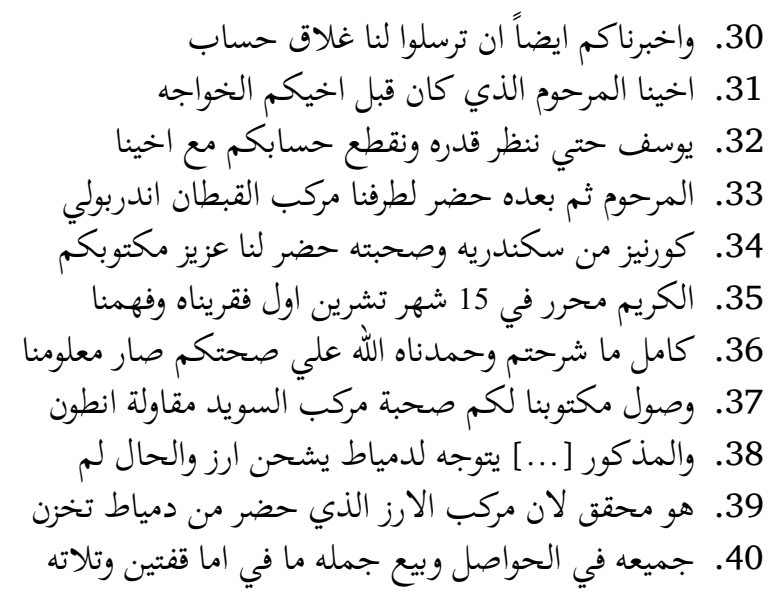

\section{Top Margin}

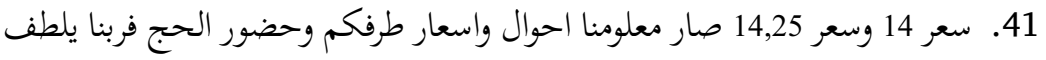

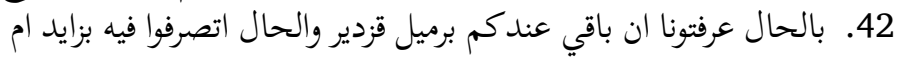

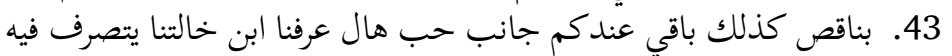

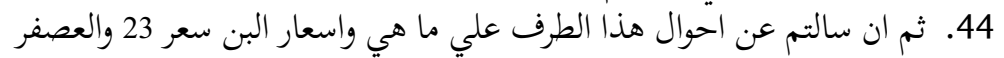

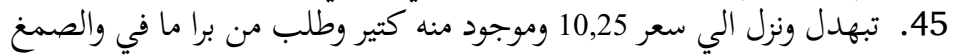

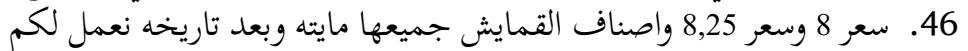

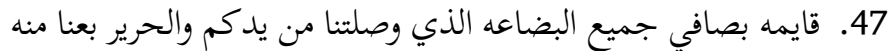

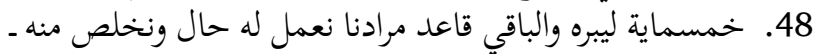

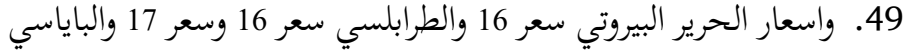

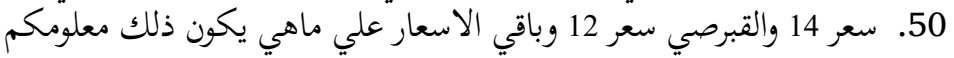

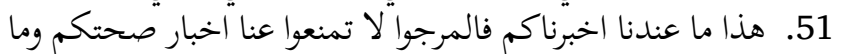

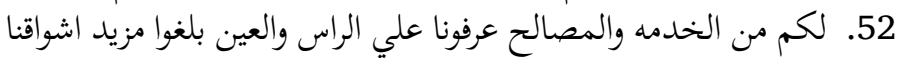

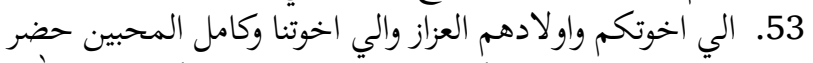

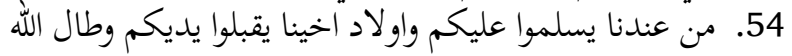

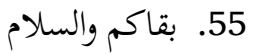




\section{Translation}

\section{Envelope}

1. With the help of God

2. To be sent to Cairo, to the hands of the dear brother Kawāja Dimitri Kayr

3. in well-being

4. $\mathrm{b} \mathrm{m}$

\section{Recto}

(5) To the Excellency, my dear brother Kawāja Dimitri the honourable, may God prolong his life. (6) After (expressing) our intense longing for you, it will not have escaped your notice that previously we sent you a letter with the ship of captain Panofisk (7) Raguzī in answer to your letters. God willing, (the letter) found you well. We informed you about the arrival of the four bales (8) of safflower and two bales of yellow wax and six packets of coffee that you sent on our account via Damietta. When (9) you inform us about the price including expenses, we will register it for you. Also, we told you that Antwān made (10) a list of the income and expenditures as set down in the records, and he sent it to you with Panofisk. Then (11) we informed you about the missing bale of safflower and two bales of cloth. We wrote to Yūsuf (12) Faranjī to check our records in Alexandria and to see if they were lost in the ships which were lost (13) or whether there was a mistake. You should urgently inform us about this so that he does not forget about it. When you have inspected the (14) aforementioned list, you should close the account. You should inform us of its correctness and send us an annulled list 
(15) so that we can see the extent of it, and close the account, because it has taken so much time. There is nothing left but a revision (16) from your side to our side and vice versa. Now, we hope that this will be the end of the account that Antwān sent to (17) you and there is no disparity. We informed you that we did not receive letters from 'Abūd Šalabī, we do not (18) know what his desire for these stones that you sent is. So please

\section{Signature Bottom Left}

19. Your sincere friend

20. Yūsuf

21. Baktī

22. $\mathrm{m}$

\section{End Right Margin (Date)}

23. Year 1759 (written) on

24. 16th of the Second

25. Kānūn

\section{Right Margin}

(26) My brother, when this letter reaches you, you should send (27) a letter to him and inform him to send us a reply and to tell us (28) what he wants, because we spent two good half-dinars on the preparation (29) of these stones and on setting them, which has been delaying us. (30) Also we informed you to send us the final account calculation (31) of our deceased brother, which was (for the period) before your brother Kawāja (32) Yūsuf's (account) so that we would know how much is it, and to cut off your account from the one of our deceased (33) brother. Then, the ship 
of captain Andropoly Korniz arrived in our area (34) from Alexandria, with it came to us your dear honourable (35) letter dated to 15th Tishreen Awwal. We have read it and understood (36) all of what you had explained. We thanked God for your well-being. We knew about (37) the arrival of our letter at yours with the Swedish ship hired by Antwān (38) and the mentioned [...] who had the intention of heading to Damietta to load rice. Well, this is not (39) confirmed, because the rice ship that came from Damietta was stored entirely (40) at the (government) corn stores, and there is no outright sale option, only two or three baskets are available

\section{Top Margin}

(41) at a price 14 and 14,25. We learned about the prices and the conditions (of merchandises) in your area during the time of Hajj, may God (42) give his mercy. You informed us that there is one barrel of tin plating left with you. Now, you should get rid of it (literally: sell it out with profit or loss). (43) Also, there is some cardamom left with you. We informed our cousin to sell it. (44) If you are asking about the news in our area, it is as usual. The coffee price is 23 and the safflower (45) is depreciated, and its price went down to 10,25 . There is enough available, and there is no demand for it from abroad. The gum arabic is (46) priced at 8 and 8.25. All types of clothes sales are dead. Afterwards, we will prepare for you (47) a list of the net of all merchandises that arrived from your side. Concerning the silk, we sold (48) five hundred libra from it; the rest is sitting (on the shelves). We wish that we could manage to sell it. (49) The prices of the Beiruti silk 
is 16, and the Tripolitan is 16 and 17, and the Bāyāsī (50) is at 14 , and the Cypriot is at 12 . The rest of the prices are unchanged; you should know this (51) for now, this is all the news we have. We wish that you do not cut us off from news about your health. Whatever (52) you need and desire, please let us know (we will do it) with pleasure. Send our many greetings (53) to your brothers and their dear children, and to our brothers and all the beloved. People (54) from here are sending you greetings. The children of our brother are kissing your hands. May God prolong your (55) life. Peace.

\section{Commentary}

Line 7

اربعة بالاة 'four bales'. Final $t \bar{a}$ ' is frequently spelled as $t \bar{a}^{\prime}$ marbūta. Line 8

'which you sent' (see also twice in line 12 and in line 18). The use of the plural relative pronoun for inanimate objects is slightly unusual here. The writer, Yūsuf Baktī, appears to favour this hypercorrect form, perhaps seen as more elevated style, as it also appears in another letter of his to a different addressee, interestingly, a Muslim correspondent.

Line 13

'your inspection'. The colloquial itfa'cala stem appears frequently in the mercantile letters of the Prize Papers.

Line 16

نهايت الحساب 'the end of your account'. Just as final $t \bar{a}$ ' may be spelled with $t \bar{a}^{\prime}$ marbūta, so tā marbūta is spelled with $t \bar{a}^{3}$. 
Line 17

'the end of your account'. In the mercantile letters, lam is not as frequent as in clerical letters, but it does occur, here with the perfect to negate the past. 


\title{
18. HִANNĀ AL-ṬABĪB, RIḤLAT AL-SHAMMĀS ḤANNĀ AL-ṬABĪB ILĀA BALDAT ISTANBŪL $(1764 / 65)$
}

\author{
Feras Krimsti
}

Gotha Research Library, Gotha, Ms. orient. A 1550. The text excerpt is selected from folios $14 \mathrm{a}-14 \mathrm{~b}$.

\section{Transcription}

Folio 14a

$$
\begin{aligned}
& \text { 13. بلاودون وصلنا اليها بعد ستة ساعات وطريقها سهل جميل جداً }
\end{aligned}
$$

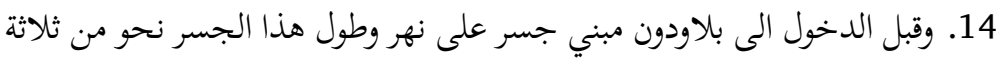

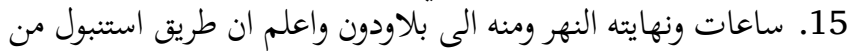

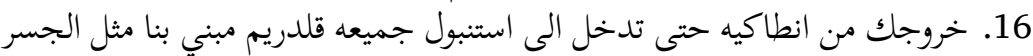

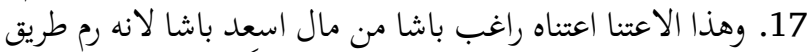

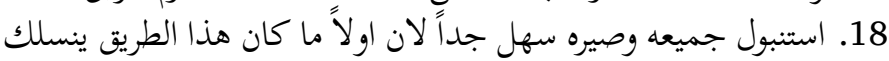

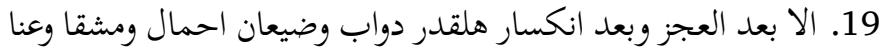

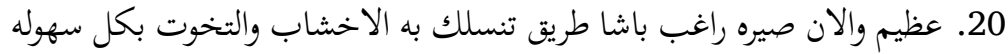

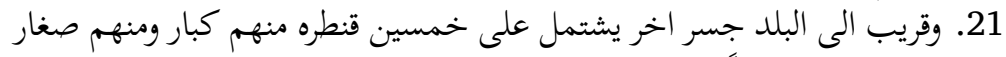

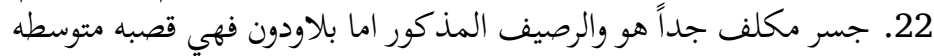

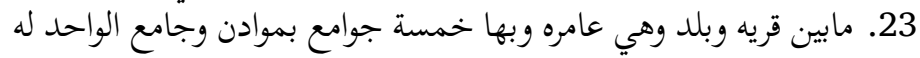

Folio 14b

1. قبه رصاص وهو جامع مكلف وماء هذه البلده جيد وهي بلاد مرخصه لاننا اخذنا 


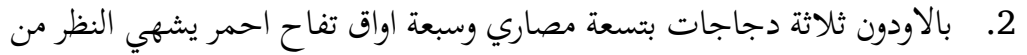

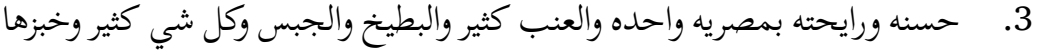

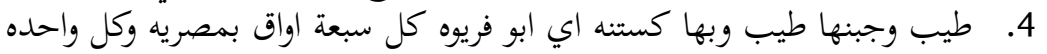

$$
\begin{aligned}
& \text { قدر } \\
& \text { 5. جوزه كبيره وجديد شي ما يجي منه الى هذه البلاد ولهذه المدينه سوق عامر }
\end{aligned}
$$

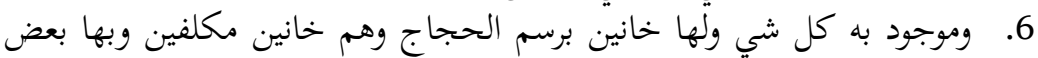

$$
\begin{aligned}
& \text { احجار } \\
& \text { 7. مكلفه مصوره واحجار عليهم صلبان ولها قساطل ماء مكلفات ملات بنا ملوك قدما }
\end{aligned}
$$

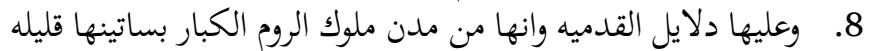

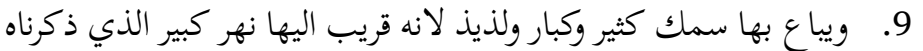

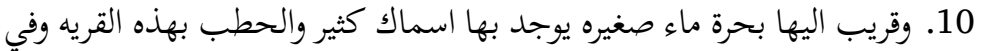

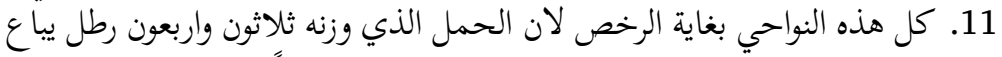

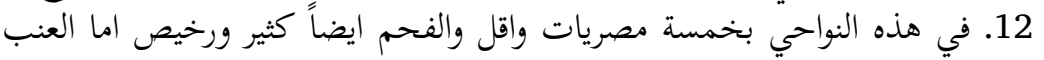

$$
\begin{aligned}
& \text { والجبس هذه الني }
\end{aligned}
$$

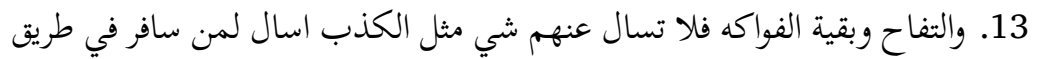

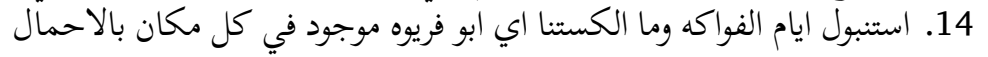

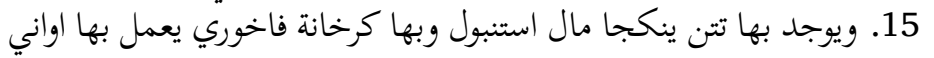

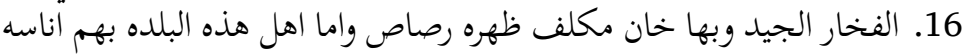

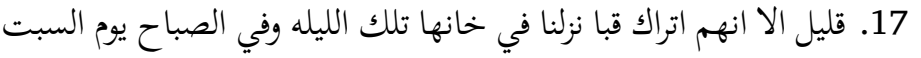

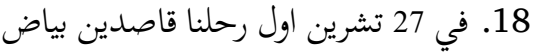

\section{Translation}

Bolvadin

[14a] (13) We reached it after six hours and the road is easy and very beautiful. (14) Before Bolvadin, a bridge was built over the river, and the bridge is about three (15) hours long and leads to the river [=Akar Çayı] and from there to Bolvadin. You should know that the road to Istanbul, from (16) when you leave Antakya until you enter Istanbul, is all kaldırm, built like a bridge. (17) Ragıp Paşa provided this, using As'ad Paşa's money, by repairing the road (18) to Istanbul and making it very easy. Because 
initially one could only pass along the road (19) if one put up with weariness, many an injured beast, the loss of burdens, troubles, and great problems, (20) but now Ragıp Paşa made the road so easy that wood and litters can be transported easily. (21) Close to the town, there is another bridge consisting of fifty arches, big ones and small ones, (22) a very pretty bridge this is with the aforementioned pavement. As for Bolvadin, it is a medium-size keep, (23) between a village and a town, and it is prosperous. In it are five mosques with minarets one of which [14b] (1) has a leaden dome and it is a pretty mosque. The water of this town is also good. It is a cheap town because we bought in (2) Bolvadin three chickens for nine misriya, seven ounces of red apples, which whet the appetite with their (3) beauty and their scent, for a single misriya, many grapes, honey melons, and water melons, a lot of everything. [Bolvadin's] bread (4) is delicious and its cheese is delicious. There are also chestnuts, i.e., Abū Furaywa; seven ounces of them cost a misriya and each single one of them has the size (5) of a big walnut. There is nothing new that would not come to this town. This city has a prosperous market (6) and everything is available there. It has two khāns for pilgrims and they are two pretty khāns. There are some (7) pretty carved stones and stones with crosses on them. [The city] has pretty water fountains, built by ancient kings (8) and displaying evidence of their antiquity, and they come from the big cities of the Greek kings. There are few gardens (9) and a lot of tasty big fish is sold in them, because a big river, which we mentioned before, (10) is close and a small lake with a lot of fish is also close. The wood in this village, (11) and in the entire area, is very cheap because a 
load that weighs thirty and forty rațl is sold (12) in this area for fifty misriya or less, and charcoal is also plentiful and cheap. As for the grapes, the honey melons (13), the apples, and the rest of the fruit, don't ask about them-it is as if they were illusions. Ask someone who travels on the road (14) to Istanbul during the fruit season. As for the chestnuts, i.e., Abū Furaywa, loads of them are available everywhere. (15) There is tütün yananca belonging to Istanbul in [the town], a pottery workshop where good earthenware is produced, (16) and a pretty khan the roof of which is leaden. As for the people of this town, they are hardly civil, (17) just vulgar Turks. During that night, we stayed in the [town's] khān and on Saturday morning, (18) 27 October [1764], we departed, heading to Bayat.

\section{Commentary}

Ḥannā al-Ṭabīb (c. 1702-1775) was a Maronite physician from Aleppo with contacts among bureaucratic circles in Istanbul. While his travelogue in general contains numerous dialectal elements, the text is not colloquial in the strict sense; rather, a striving for the use of classical Arabic can be detected, e.g., in the excerpt sahl jiddan, and not ktïr, for 'very easy'; yūjad bihī asmāk, and not fi asmāk, for 'there is fish'; ayḍan 'also', instead of kamān; etc. It is not clear if the travelogue was intended to be read aloud or silently in a private setting, but the style is generally unofficial, as evinced in the excerpt by the frequent recurrence of casual phrases, e.g., the water of the town is said to be 'good' (jayyid), bread and cheese are 'delicious' (tayyib)—without further speci- 
fication. The narrator addresses the reader directly with imperatives, here, notably, ilam 'you should know' and lā tas'al 'anhum 'don't ask about them'. Also quite notable is the tendency to use emphatic language, e.g., phrases like shi mithl al-kadhib 'it is as if they were illusions.'

Folio 14a, line 16

. Oلدريم. Ottoman Turkish kaldırım 'pavement.'

Folio 14a, lines 17, 19; 14b, line 7

قدما, عنا ,اعتنا, and further instances. The absence of final hamza can be regularly observed in so called 'Middle Arabic' texts. See Lentin $(2011,220)$.

Folio 14a, line 18

صيره سهل جداً 'he made it very easy' (to traverse).

Folio 14a, line 19

هلقدر 'to such a degree', here 'so many'. Ha + l+ qadar is equivalent to the demonstrative construction hädha l-qadar and the result of the assimilation of the demonstrative pronoun. See Kallas (2012, 236-37) and Barthélemy (1935-1969, 870-71).

Folio 14a, line 22; 14b, lines 1, 6, 7, 16

مكلفين here 'pretty'. The extremely frequent use of this word is a peculiarity of Hannā al-Ṭabīb's writing style (in the excerpt six times, in the entire travelogue more around three hundred occurrences). In Arabic, the use of the word mukallif with this meaning is rather unusual. Hannā may have used Ottoman Turkish mükellef, which means 'great, grandiose, magnificent'. 
Folio 14a, line 23

بموادن. Hamza in the plural ma'ādhin is replaced by $w \bar{a} w$. The $d h \bar{a} l$ is replaced by a $d \bar{a}$. Interdentals shifting into postdental plosives are a regular feature in the Aleppo dialect and can be detected elsewhere in 17th- and 18th-century travel accounts. See Kallas (2012, 224-26, especially 225-26).

Folio 14b, lines 2, 3, 4, 12

مصريات or مصاري Plural مصريه / مصريه

Folio 14b, lines 2, 4

اواق) (اوقية plural weight measurement. The Aleppo ūqiyya corresponded to 100 dirhams or 320 gr. See Barthélemy (19351969, 905).

Folio $14 \mathrm{~b}$, line 2

literally 'which impassionate the eye'.

Folio 14b, lines 4, 14

literally 'the father of the little fur'. The kunya refers to the furry shell of chestnuts.

Folio 14b, line 4

قدر 'of the size, of the dimensions'.

Folio 14b, line 5

وجديد شي ما يجي منه الى هذه البلاد. The phrase is syntactically awkward; it supposedly means 'there is nothing new that would not come to this town'; however, the negation 'there is nothing' is missing.

Folio 14b, line 6

kull shi < kull shay' 'everything'. On the absence of final hamza, see above. On the different uses of shi, see also Barthélemy (1935-1969, 421-22). 
Folio $14 \mathrm{~b}$, line 11

حمل ‘the load of a beast of burden'. See Barthélemy (1935-1969, 178).

Folio 14b, line 11

رط a weight measurement. The Aleppo ratl corresponded to the weight of 800 dirhams (2.566 kg). See Barthélemy (1935-1969, 284).

Folio $14 \mathrm{~b}$, line 13

it is as if they were illusions', i.e., they are so fantastic that they can only be made up.

Folio 14b, line 15

تتن ينكجا Probably Ottoman Turkish tütün yananca 'tobacco that burns'. The reference may be to tobacco that is smoked (as opposed to smokeless tobacco).

Folio 14b, line 15

كرخانة Ottoman Turkish kerhane 'workshop', here a 'pottery workshop'. On the dialectal word in Arabic, karkhāna, see also Barthélemy (1935-1969, 709).

Folio $14 \mathrm{~b}$, line 17

قبا Ottoman Turkish kaba 'rough, vulgar'. 



\title{
19. SYRIA 1: CHRONICLE OF IBN AL-ṢIDDĪQ (1768)
}

\author{
Jérôme Lentin
}

The chronicle of Ibn al-Ṣiddīq (Hasan, al-šahīr bi--), Ġarāyib albadāyi` wa-'ajāyib al-waqāyi`, covers the events between $1182 / 1768$ and $1185 / 1771$ and is a contemporary account. We have no information about the author. The manuscript (a unicum) is part of the Wetzstein Collection, in the Staatsbibliothek zu Berlin - Preußischer Kulturbesitz (We II 417, Ahlwardt's catalogue vol. $9 \mathrm{n}^{\circ}$ 9832). The edition by Yūsuf Nu'aysa (1988) is very faulty, full of mistakes and inaccurate readings. Long passages are omitted or mixed up. The text below is taken from the manuscript (p. 70; Ms fo 80b-81a).

\section{Transcription}

$$
\begin{aligned}
& \text { فعلوا اهل حران ما امرهم فراحوا' كبسوا اطراش² ابن احسين ارشيد وجابوهُ3 الى الشام فدري }
\end{aligned}
$$

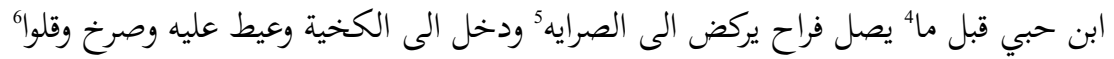

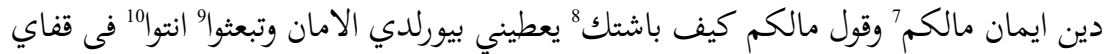

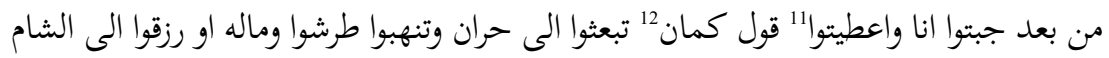

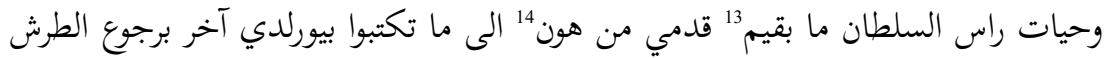

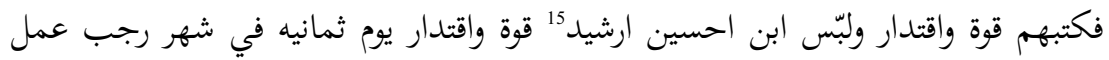

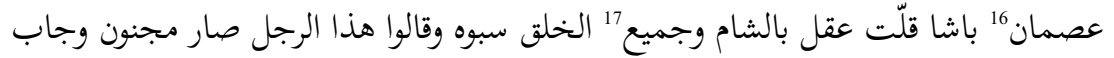

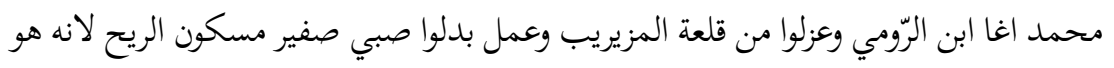




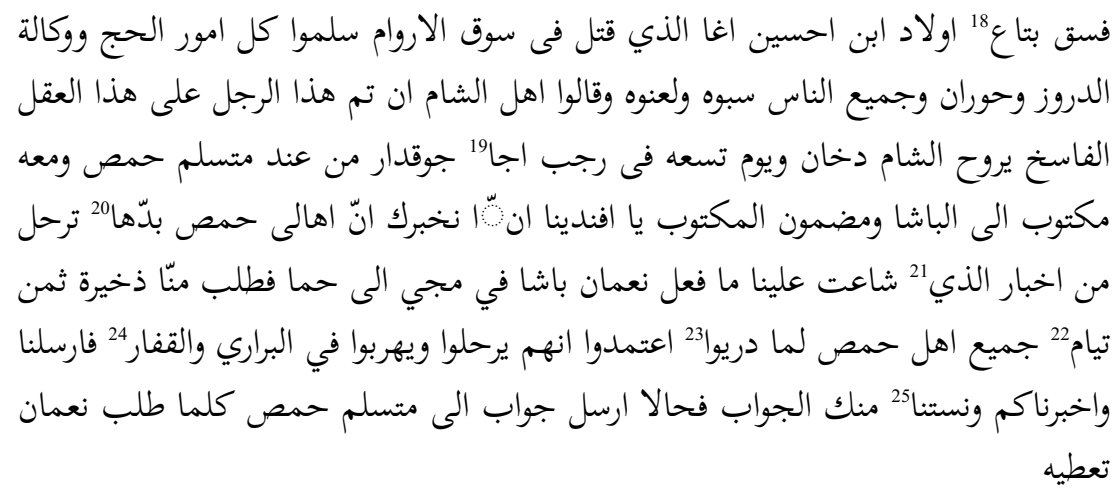

\section{Translation}

The people of Harrān [ = Harrān al-'awāmīd, in the vicinity of Damascus] did what he had ordered them to do and they went and looted the cattle of Husayn Rušayd and brought it to Damascus. Ibn Hibbì got aware of this before its arrival and he rushed inside the Palace to find the kahiya [intendant] and shouted and screamed at him and said: you, man of no faith! You traitor to your word! How is it that your Pasha gives me a written order (buyuruldī) granting me safe-conduct and quarter and that you send [people / messages] behind my back [to harm / discredit me], after I have brought it to you and after you have given your word. Moreover, you send [people] to Harrān to loot his cattle and his goods and livelihoods and bring them to Damascus. By the life of the Sultan, I will not remove my foot from here until you write a new written order ordering that the cattle must go back. He compelled them to write [it] by force. He bestowed marks of honour upon Ibn Husayn Rušayd by force. On the 8 Rajab, 'Uțmān Bāšā behaved improperly in Damascus. All the people insulted him, saying: this man has turned crazy! He let 
Muhammad 'Ā $g \bar{a}$ Ibn al-Rūmī come, dismissed him from the fortress of al-Muzayrīb and replaced him by a mentally ill young boy - because of his depravity with young boys. He entrusted the son of Ibn Husayn 'Ā $\dot{g} \bar{a}$, who had been killed in the Sūq al'Arwām, with the leadership of the pilgrimage, and made him his representative [wakil] for [the region of] the Druzes and Hawrān. All the people insulted and cursed him and the Damascenes said: should that man continue with his depraved mind, Damascus will go up in smoke. On the 9 Rağab a jūqadār (čūhadār) [here: a high rank messenger] sent by the mutasallim of Homs arrived bearing a letter to the Pasha saying: Sir ('Afandinā) we are informing you that the people of Homs are about to move away, because of the news that spread out and reached us about what 'Uțmān Bāšã did when he arrived to Hama: he required of us [that we supply] the provisions for eight days. When the people of Homs heard about that, they decided they would move and run away to the steppe and the desert. We have already sent you a message to inform you and we are waiting for your response. Right away, he sent his answer to the mutasallim of Homs [saying]: Grant 'Uțmān whatever he might ask.

\section{Commentary}

${ }^{1}$ راحو. See text II.9, no. 4.

2 اطراش. The usual plural of this (colloquial) word is trūš; ('a)țā̄̌s is probably a classicising form. 
3 جابوه See text II.9, no. 18.

قبل ما although attested in the Classical language, is most probably the colloquial form of this conjunction.

5 الصرايه. Shift of s > ș; cf. sarāy(a).

ق قلوا 6 qal-lo ( $<$ qāl l-o). Notice also the 'alif wiqāya after the final -o/-u (a common feature of MA orthography); cf. جبتوا tarš-o طرشوا žibt-o, عزلوا rizq-o, عزول razal-o, بدوا badal-o.

7 > *mā l-kum 'not to you' = 'you don't have'.

8 باشتك. Borrowings like $b \bar{a} \check{s} \bar{a}$ often have a $t$ in the construct state (and are often written with a $t \bar{a}$, e.g., باشة, also in the absolute state).

9 تبعثوا. For the $-\bar{u}$ form (and not $-\bar{u} n$ ) of the $2 \mathrm{pl}$ of the imperfect see text II.9, no. 7. The verb $b a^{c} a t a / b a^{\prime} a t$ often functions as a factitive auxiliary (see Lentin 1997, §4.5.1, 633-36); the auxiliary verb can follow immediately or be preceded by the conjunction wa, as in the just following تبعثوا الى حران وتنهبوا 'you send [people] to Harrān to loot his cattle', which could very well be translated 'you let loot his cattle in Harrān'. Cf. also text II.14, no. 9.

${ }^{10}$ انتو colloquial pron. ('intu). Notice also the 'alif wiqāya after the final $-u$ (cf. n. 6).

11 اعطيتوا. The (colloquial) -u form (and not -um) is used most of the time in MA for the $2 \mathrm{mpl}$ and $2 \mathrm{fpl}$ of the perfect.

12 كamān, colloquial adverb.

بقيم: 13 (a)qìm, i.e., $b-+1 c s$ of $q \bar{a} m$, with $i$ theme vowel (cf. Classical 'aqāma) 'to remove'. The $b(i)$ - imperfect, significantly used here in the first person and in reported (direct) speech, indicates modality (here modal future in a strong assertion) as well as the commitment of the speaker.

14 هون hawn/hōn, colloquial adverb. 
ارشيد ارشيد. The initial prosthetic 'alif indicates (in this case) that the noun begins with CC-. Thus, we have to read something like Hsēen and Ršêd (Rašìd is never abbreviated as *Ršid).

16 عصمان *Utmān > 'Usmān > 'Uṣmān.

17 . See text II.9, no. 5.

بتاع is one of the numerous 'genitive particles' used in MA texts (see Lentin 1997, §17.8.2, 745-47). Its particular (qualificative) value here is not frequent.

${ }^{19}$ اجا اža (/žâ) 'to come' (Classical jāa'a) occurs regularly in MA texts.

20 بدّهـا bidd-hā. Colloquial bidd- + pronominal suffix 'to want, wish' or 'to be intending/going to' is common in (the most colloquialising) MA texts.

الذي invariable (see text II.9, no. 15). Also notice the

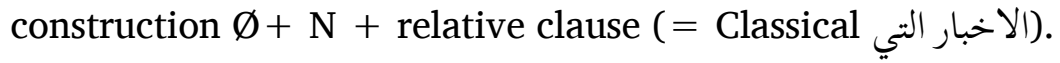

22 colloquial țman-t-iyyām.

23 diryū. Morphologically colloquial (diri 'to become aware, hear').

24 في البراري والقفار. This literary cliché is very common in 'popular' literature, especially in the siras.

25 nistanna (colloquial). 



\section{A LETTER TRANSMITTED BY \\ AMBASSADOR HAJJ MAHDĪ BARGASH \\ FROM SULTAN MUHAMMAD BIN \\ 'ABDALLAH TO SULTAN ABDUL HAMĪD \\ (1789 CE)}

\section{Ahmed Ech-Charfi}

CBH. 226/10511

A letter transmitted by Ambassador Hajj Mahdī Bargash from Sultan Muhammad Bin 'Abdallah to Sultan Abdul Hamīd informing him that he is sending a present of four ships and 536 liberated Ottoman prisoners.

\section{Transcription}

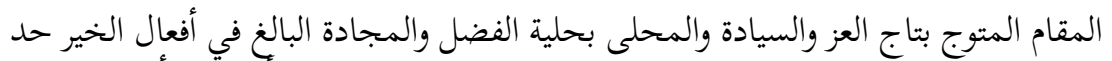

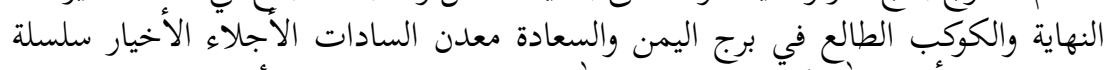

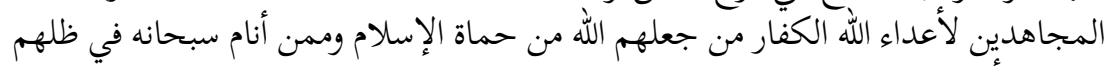

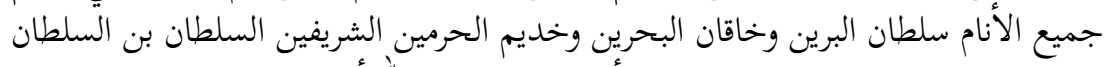

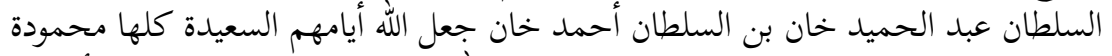

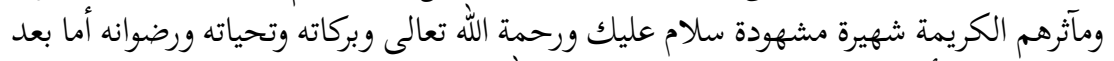

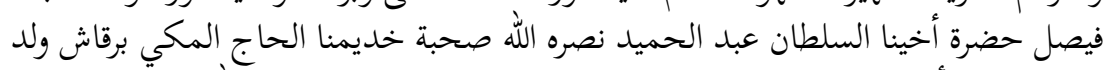

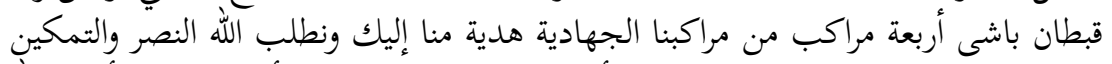

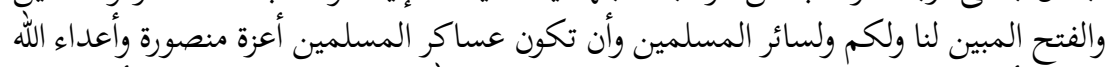

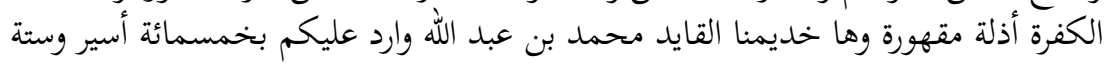




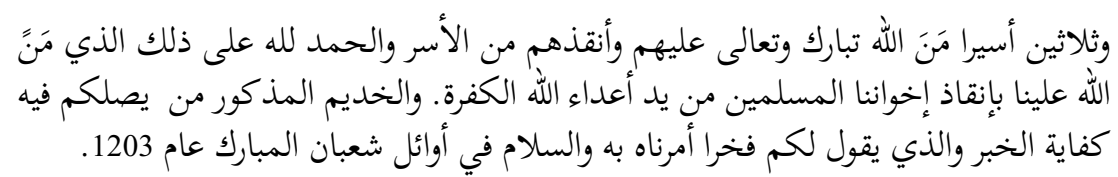

\section{Translation}

Your Majesty, with a crown of splendour and sovereignty and adorned with favours and glory; you, perpetrator of deeds of ultimate generosity; you, a planet in the horoscope of good omen and happiness; you, who come from a lineage of the best noble sovereigns forming a chain of mujāhidin against unbelievers and enemies of Allah, the mujāhidin whom Allah has given the responsibility to protect Islam and provide peace for all people; you, sultan of the two lands, Khagan of the two oceans, and custodian of the two holy mosques; a sultan and son of a sultan; Sultan Abdul Ḥamīd, son of Sultan Ahmed Khan, may Allah grant them everlasting happiness and make their good achievements famous and celebrated; peace, mercy, and blessings of Allah be upon you!

There will be delivered to our brother-Sultan Abdul Hamīd; May Allah make him glorious-by our servant Hajj AlMakkī Bargash, son of Captain Pasha, four of our navy vessels, as a gift from us to you. We ask Allah for glory, empowerment, and further conquests to us and to you and all Muslims so that Muslim armies always prevail and their enemies be vanquished and humiliated. Also, our servant Caid Mohammed bin Abdellah will deliver to you five hundred and thirty-six (Ottoman) prisoners freed by the help of Allah-we thank Him for that and for helping us to liberate our Muslim brothers from the hands of unbelievers, Allah's enemies. The aforementioned servant will provide you 
with more information on the operation he carried out under our order.

Peace be upon you,

Early Sha'bān of the year 1203 



\title{
21. ARAB MERCHANT LETTERS FROM THE GOTHA COLLECTION OF ARABIC MANUSCRIPTS
}

\author{
Boris Liebrenz
}

Arabic letters concerning personal and business matters abound in the pre-Ottoman period, but become extremely scarce afterwards. Since the early 19th century, the Forschungsbibliothek Schloss Friedenstein, Gotha (Germany) has held seven volumes of merchant letters dating from the middle of the 18th century until 1806. Numbering more than 1,600 letters, this repository seems to be the largest one preserved from the period.

The writers and addressees are both Christian and Muslim and examples of both will be given here. There are some overlaps, but in general the Christian letters cover a network of merchants of Syrian origin that operated between Cairo, Alexandria, Damietta, Jaffa, Jerusalem, and Damascus, with mentions of further extensions to Istanbul, Cyprus, and Rhodes. The letters by Muslims (with few Christian examples) belong to several networks of Muslim merchants centred in Cairo. In the case presented here, the network revolves around two brothers Abū Qașișa and letters are exchanged primarily between Jedda, Suez, and Cairo. 
The language of the Christian network is marked by unequivocal embracing of the colloquial. Its features include: loss of gender distinction, plural, or dual; replacement of emphatic consonants with their unemphatic counterparts (מ ;

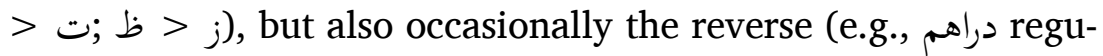
larly becomes ضراهم); case endings lost or wrong (بكل خيراً); negation of all tempi with lam followed by a verb in perfect tense (lam $k \bar{a} n$ ) or even negation with lam with no verb at all (lam huwa $b \bar{a} q \bar{l})$; imperfect verb forms are often prefixed with a ب. The lexicon includes not only several words of Italian and French origin (بوليصه), but also several particles of colloquial usage (šŭ, layš, minšān). The orthography changes with the individual scribes, but some features are prevalent: $t \bar{a}^{\jmath}$ marbūta becomes $t \bar{a}^{\text {’ }}$ and vice versa; plene writing of long vowels that are regularly omitted (ذالك); the 'alif of the article is dropped when the initial hamza is silent (بلسلامة); individual words can be joined into one when

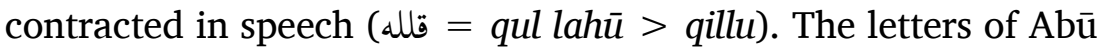
Qașīṣa's network are generally more in line with the grammatical and orthographic rules of written Arabic although any of the aforementioned phenomena may occur.

The address differs between the two networks in layout and sometimes wording. Those from the Red Sea and Egypt are written in one line at the top of the verso side. The Syrians write several lines at the centre of what was the outer side of the folded letter. The same can be observed from other contemporary letters from the Ottoman Empire north of Egypt. This formal feature appears to mark a general division between letters written in 
Greater Syria and north of it (of which the Syrian merchant diaspora is an Egyptian extension to the south) on the one side, and those coming from Egypt, the Arabian Peninsula, and further south, on the other.

\section{Transcription}

MS Gotha orient. A 2837, doc. 1

Fransīs Bernard Dumyān to his cousin Giovanni Rūk / Rocco and his maternal uncle Yūsuf Anțūn Tarjumān Talāmās / Giuseppe Talamas in Damietta. The writer's unnamed sister ${ }^{1}$ is also mentioned in the internal address.

The details of the matter reported in this latter are not always clear to me. ${ }^{2}$ Yet the contours of dramatic events revolving around two fierce legal cases taking place in Rosetta are evolving. They first pitted Fransīs against a powerful consul, while he believes he has the whole community of consuls on his side, securing documents from as far as Istanbul. The second case is that of a murder that had taken place in the Frankish quarter and sees the consuls united against the city's governor, who is unable to present the murderer.

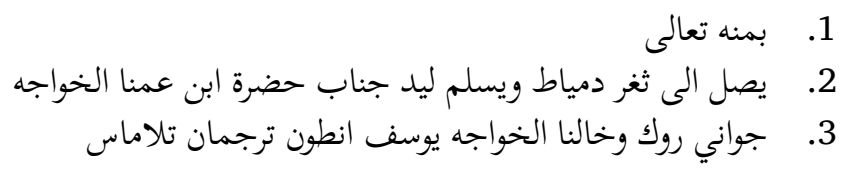

${ }^{1}$ Theresia, according to other letters.

${ }^{2}$ The matter is taken up again in Forschungsbibliothek Gotha, Ms. orient. A 2837, no. 27 (dated Șafar 30, 1219), which this one must precede, since the murder is mentioned as an immediate case here unlike in no. 27. 
MSig. Guiseppe Talamas Inca-

ricato dell'Agenzia d Spagna opera

altiss. Giovanni Rocco in

\section{Damietta}

\section{Recto}

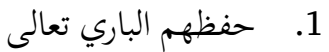

$$
\begin{aligned}
& \text { 2. } \\
& \text { 3. جناب حضرة شقيقتنا المصيونة وابن عمنا سنيور جواني وخالنا سنيور يوسف }
\end{aligned}
$$

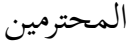

$$
\begin{aligned}
& \text { 4. غب عروض الشوق اليكم مع تزايد الاشتياق لجنابكم المعروض لبين اياديكم }
\end{aligned}
$$

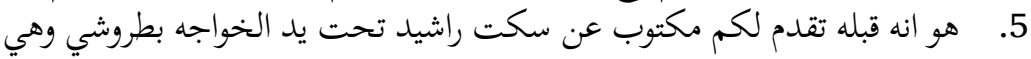

$$
\begin{aligned}
& \text { 6. بوصولنا لاجل الاطمان انشا الله تعالى يكون وصلكم وانتم بخير الان بان } \\
& \text { 7. }
\end{aligned}
$$

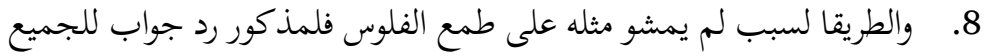

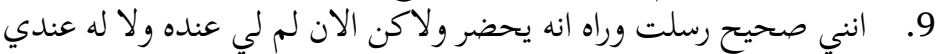

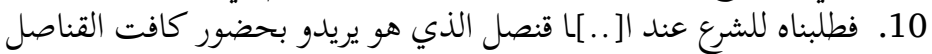

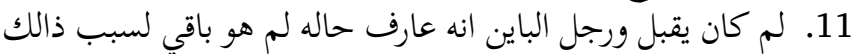

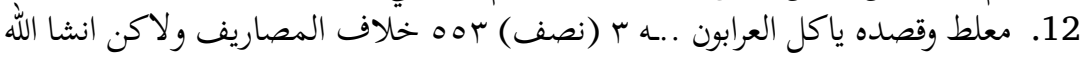

$$
\begin{aligned}
& \text { تعالى } \\
& \text { 13. ووجود المحبين منبظر عينه بوصط كرفوه لان كافت القناصل ختمو لنا الاوراق }
\end{aligned}
$$

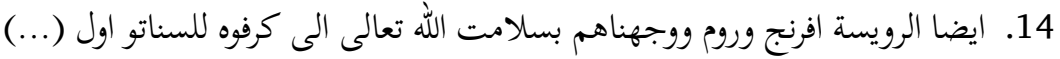

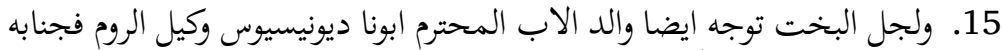

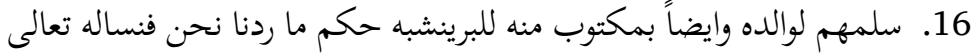

$$
\begin{aligned}
& \text { 17. - 17 د دعاكم فرنسيس }
\end{aligned}
$$

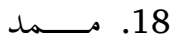

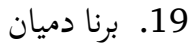




\section{Righthand Margin}

$$
\begin{aligned}
& \text { 22. ان يطول بعمر المحبين فلرجا دايماً تكونو مطمنين }
\end{aligned}
$$

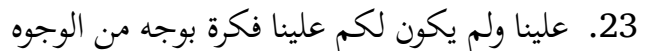

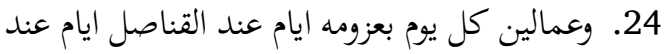

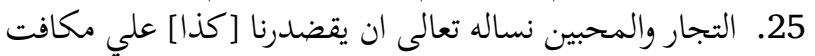

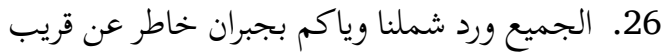

$$
\begin{aligned}
& \text { 27. بجاه والدت السياده وابنها الحبيب وكافت بران } \\
& \text { 28. القديسيين امين }
\end{aligned}
$$

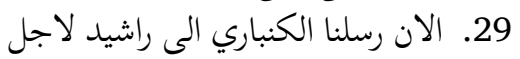

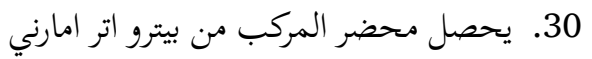

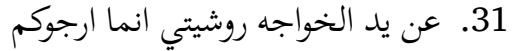

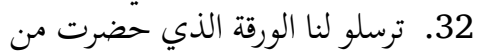

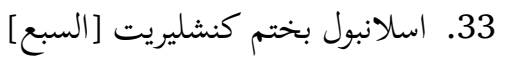

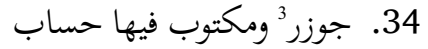

$$
\begin{aligned}
& \text { 35. محضر المركب وبتجادوها بين فين احسباب }
\end{aligned}
$$

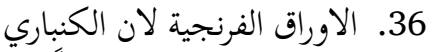

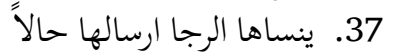

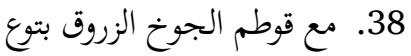

$$
\begin{aligned}
& \text { 39. 39. الابيتو الذي عليه السبابيطا الزرف بتر }
\end{aligned}
$$

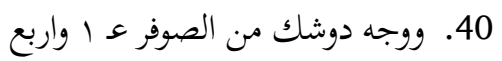

$$
\begin{aligned}
& \text { 41. وجوه امخدات بلونو ام خمسة الموركا }
\end{aligned}
$$

${ }^{3}$ This short-lived Republic of the Seven Islands or Septinsular Republic comprised several islands off the coast of modern Greece in the Ionian Sea, among them Corfu, mentioned in the letter. It was established by a joint Ottoman-Russian military intervention that took the territories from the French and it existed between 1800 and 1807, after which they were first annexed by Napoleon and then transformed into a British protectorate from 1815 to 1864. 


\section{Top Margin}

$$
\begin{aligned}
& \text { 43. د دايماً وسلامنا للجميع كل حي إسي }
\end{aligned}
$$

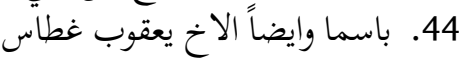

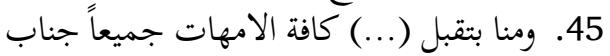

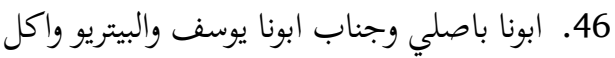

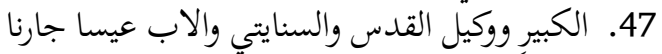

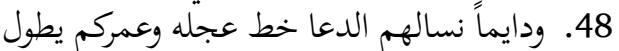

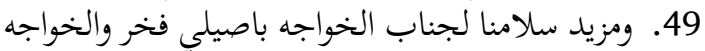

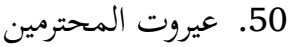

\section{Verso}

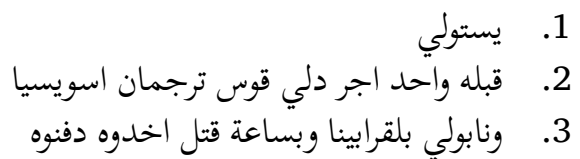

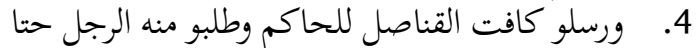

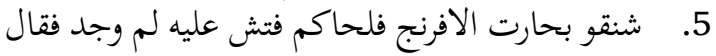

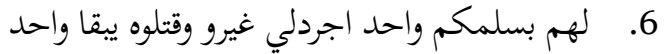

8.

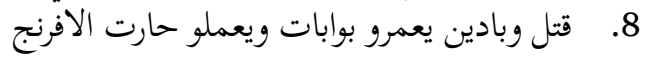

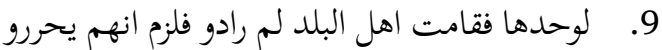

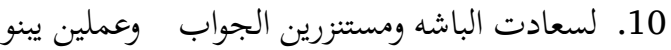

11. بلسد وكل يوم سو خره على الولاد الاد البلد فربنا

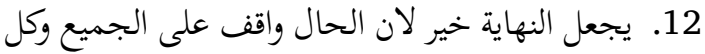

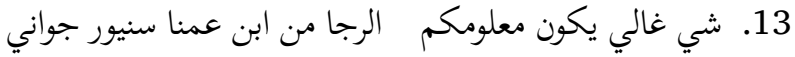

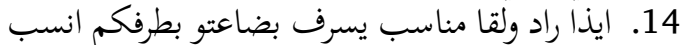

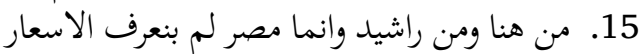

16. 16. دنما الحرب ودن رايماً حد ذالكا دصر كفاية دمتم 


\section{Translation}

With His blessing

May it arrive at the harbour Damietta and be expedited to the hand of his excellency our cousin the master

Juwānī Rūk and our maternal uncle the master Yūsuf Anțūn Tarjumān Talāmās, the esteemed, safe and sound.

\section{Recto}

(1) May the Exalted protect them!

(2) Amen.

(3) [To] his Excellency our sister, our cousin Signor Juwānī, and our maternal uncle Signor Yūsuf, the esteemed.

(4) After expressing the longing for you with exceeding yearning for your Excellency, what we have to put before you (5) is this: you previously received a letter regarding the mint of Rāšìd by hand of the master Batrūshī, in which we informed you (6) about our arrival to put you at ease. God willing, it reached you and you are fine. Now (7) we want to report to your Excellency on the issue of the consul when he found all the consuls in support of us (8) because, unlike him, they were not driven by greed for money. Said consul answered to the crowd: (9) "It is true that I sent after him so that he would appear. But right now I have no claim against him, as he has none against me. (10) We had cited him to court at [...] a consul who wanted him in the presence of all the consuls, (11) which he refused." It is clear that this is a man who knows his ways and won't stay blemished because of that. (12) His intention is to pocket the down payment-533 1/2 
[piasters and] 3 [misriyya] plus expenses-but-God willing(13) with the presence of loving friends, he will be thwarted, with the mediation of Corfu. Because all the consuls have sealed papers for us, (14) also the heads of the monasteries of the Europeans (Ifranj) and the Orthodox (Rüm). We delivered them to Corfu for the Senate first [...]. (15) And for good luck, the father of the esteemed Father Diyūnīsiyūs, guardian of the Orthodox, His Excellency (16) directed them to his father, too. And also a letter from him to the Principe according to our answer. We ask God (17) Praying for you Fransīs

(18) ...

(19) Barnā Dumyān

(20)-(21) in the year 1219.

\section{Righthand Margin}

(22) to prolong the lives of our friends. Please, always be at ease (23) about us, and don't spare a thought on us. (24) We spend our days being invited, sometimes with the consuls, sometimes with (25) the traders. About the friends we ask God to enable us to satisfy (26) them all and that he would unite us in good spirit soon, (27) through the power of the Mother of the Lord, her beloved son, and all (28) the saints. Amen.

(29) Now: we sent al-Kunbārī to Rāšìd so that (30) he would get the ship's manifest from Pītrū Atrāmārnī (31) by way of the master Rūšìtī. I ask you only (32) to send the paper that arrived from (33) Islāmbūl with the seal of the consul's office of the Seven (34) Islands, as well as a letter with the account (35) of the ship's manifest. You will find it between (36) the franji 
(Italian or in Latin characters?) papers. (This is) because al-Kunbārī (37) (might?) forget it. Please send it immediately (38) together with: a (قوطم?) of blue broadcloth belonging to (39) the dress on which are the shoes; (40) and 1 kind of (دوشك?) from (الصوفر); and four (41) or five coloured pillows.

(42) This is what I ask from you, with my constant prayers,

\section{Top Margin}

(43) and greetings to everyone, each (44) by their names! Also to the brother Ya'qūb Gatțās. (45) And from us (...) all the mothers kiss (the hands of) His Excellency (46) Our Father Bāṣilī and His Excellency Our Father Yūsuf and al-Bītrīyū, the great (47) guardian, and the guardian of Jerusalem, and al-Sanāyitū, and Father 'Īsā, our neighbour. (48) We always ask for their intercession. This is written hastily! May your life be prolonged! (49) Extensive greetings to His Excellency the master Bāṣillī Fahr and the master (50) 'Ayrūt, the esteemed.

\section{Verso}

(1)-(2) Previously, one (اجر دلي) overpowered the dragoman of Switzerland (3) and Napoli with a carabine and (the dragoman) was immediately killed. They took him and buried him (4) and all the consuls sent for the governor to demand the perpetrator. They wanted to (5) strangle him in the Frankish quarter. The governor searched for him but did not find him. So he said (6) to them: "I will hand over another (اجر دلي) for you to kill. Thus it's still one (7) for one." But they did not accept. And up to date they are still looking for the (8) killer. They want to fortify the gates 
and make the Frankish quarter (9) isolated. The local people rose up and will certainly write (10) to His Excellency the pasha. And they are waiting for his answer. They set out to build (11) on the wall. The worst curse on the local people every day! May our Lord (12) give a good outcome because all business stops at this state of affairs and (13) everything is expensive. This is to let you know.

We ask of our cousin, Senior Giovanni, (14) if he so pleases, to find a better opportunity to turn his merchandise into cash (15) than here or in Rāšĩd-for Cairo we don't know the prices. (16) The war is always an obstacle for this. Enough now! May you live long!

\section{Commentary}

The address is in Italian and the lexicon of the writer, too, seems to show familiarity with Italian terms (l'abito, principe).

\section{Recto}

Line 12

العرابون. I interpret this to be a form of 'arabūn, which, according to de Biberstein-Kazimirski $(1860,209)$ means arrhes, i.e., 'deposit, down payment'.

\section{Line 38}

بتوع Like the more prevalent form بتاع, this term signifies a connection or belonging between two nouns, equivalent to the terms ذو ذابع ذات 
Line 39

. This word appears to be of a non-Arabic form and I interpret it as a rendering of the Italian l'abito 'the dress'.

\section{Line 48}

. خط عجله A standard excuse for a letter written in haste.

\section{Verso}

Line 2

اسويسيا This seems to reflect the Italian version of Switzerland, Svizzera.

Line 8

بادين. This is the dialectal expression of intention and desire which is usually formed today and in the letters with بد (badd) as an invariable noun to which a personal pronoun is attached to express gender and number, e.g., بدهم. But in this rare case, as in a few other places throughout the letters, it is formed like a verb, e.g., بدني.

MS Gotha orient. A 2837, doc. 148

Makkī Rawāy to Ṣāliḥ Abū Qaṣīṣa at the Wikālat al-Naššārīn in Cairo. The letter was presumably sent from Suez, where Makkī was posted.

\section{Transcription}

\section{Recto}

$$
\begin{aligned}
& \text { 1. يصل ان شا الله تعالى الى محروسة مصر يسلم ليد المحترم المكرم الاخ العزيز الحاج }
\end{aligned}
$$

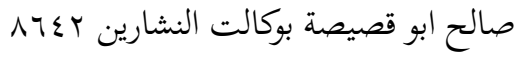




\section{Verso}

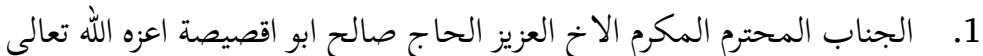

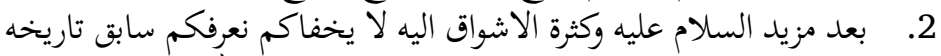

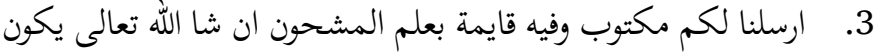

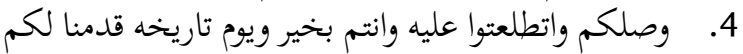

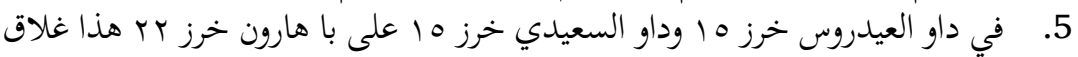

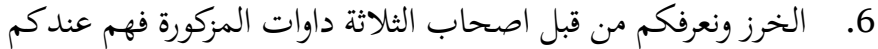

$$
\begin{aligned}
& \text { 7. } \\
& \text { 8. }
\end{aligned}
$$

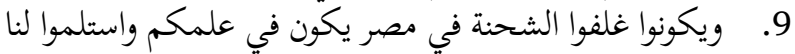

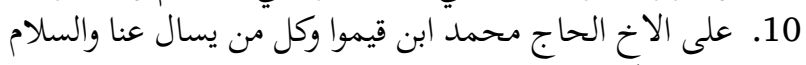

$$
\begin{aligned}
& \text { 11. 10. السيد مكي الاخ الحي }
\end{aligned}
$$

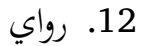

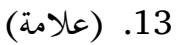

$$
\begin{aligned}
& |r| \cdot .14 \\
& \text { 15. سنة }
\end{aligned}
$$

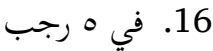

\section{Translation}

\section{Recto}

(1) May it arrive, God willing, to the well-protected Cairo and be delivered to the hand of the esteemed and noble one, the beloved brother al-ḥājj Ṣāliḥ Abū Qaṣiṣa at the Wikālat al-Naššārīn 8642

\section{Verso}

(1) His Excellency, the esteemed and noble one, the beloved brother al-hâajj Ṣālih Abū Qașị̣a, may God strengthen him!

(2) After copious greetings for him and much longing for him, it shall not be concealed from you that we inform you that 
previously (3) we sent you a letter which included a cargo manifest, God willing it has (4) reached you and you looked at it and are in good health. As of today, we have forwarded to you, (5) on the dhow of al-'Aydarūs, 15 beads, and on the dhow of alSa'īdī 15, and on (that of) Bā Hārūn 22. And that is the rightful passage of possession (gilāq) (6) of the beads. We also inform you on behalf of the three captains of the aforementioned dhows, that when they are with you (7) in Cairo you can load five loads (aḥmāl) on each dhow because of the Syrian cargo (šaḥnat alŠămiyya) (8) that is with you. Because it has reached us that they load in Cairo and are afraid to come, (9) they will wrap the cargo in Cairo. So that you know.

Greet on my behalf (10) the brother al-ḩājj Muhammad Ibn Qìmū and everyone who asks after us. Peace!

(11) al-sayyid Makkī

(12) Rawāy

(13) [signature]

(14)-(16) on 5 Rajab in the year 1210 (=15.1.1796)

\section{Commentary}

\section{Recto}

Line 1

ᄉ ₹ ' 8642 '. This number has an apotropaic function. The letters of the southern network of mostly Muslim writers who corresponded between Cairo, the Red Sea, and the Hejaz, rarely exclude it. But it is sometimes also found in correspondence of the northern, mostly Christian network. 


\section{Verso}

Line 5

غلاق. I am not certain about the meaning of this word. My translation is based on Lane's (1863-1893, VI: 2284) translation of the

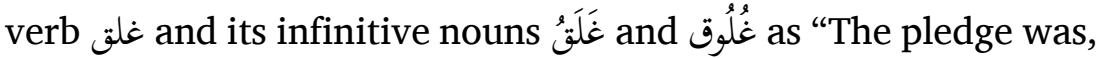
or became, a rightful possession [i.e. a forfeit] to the receiver of it," although this remains an unsatisfactory explanation. 


\title{
22. A JUDAEO-ARABIC LETTER FROM THE PRIZE PAPERS COLLECTION, HCA 32/1208/126.2 (1796)
}

\author{
Matthew Dudley
}

\section{Transcription}

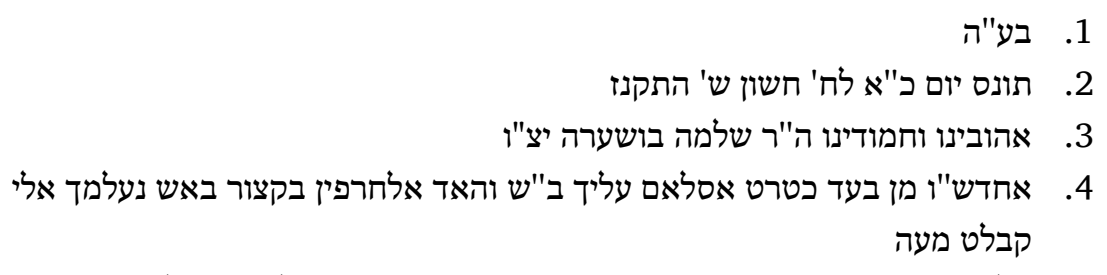

5. אלמסעי פ׳י וסט ברייט ה"ר דאענוס עז בראטך תאריך ט"ו לח' הנצ"ל וערפט מה

פיהא

6. 7. 8.

9.

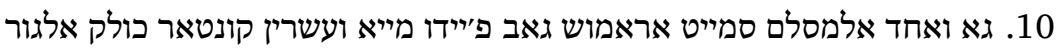

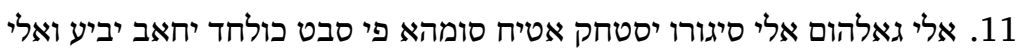

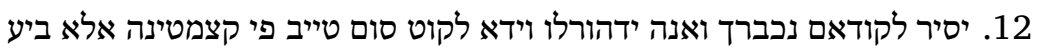

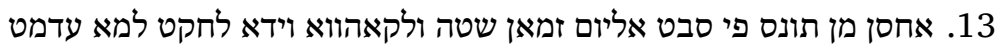
14. ואנטי ומה ידהורלך ומן אלפלוס לאכרין אלי רסלטלו ראהום באקיין מטבועין

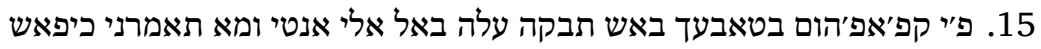

16. תעמל פ'יהום וכו"פ' אסאעה קצירא ומא ענדי חדוש באש טנוול עליד כאן

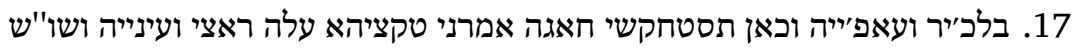
18. ע"ה שלמה צמח 19

19. - 19 


\section{Arabic Transcription}

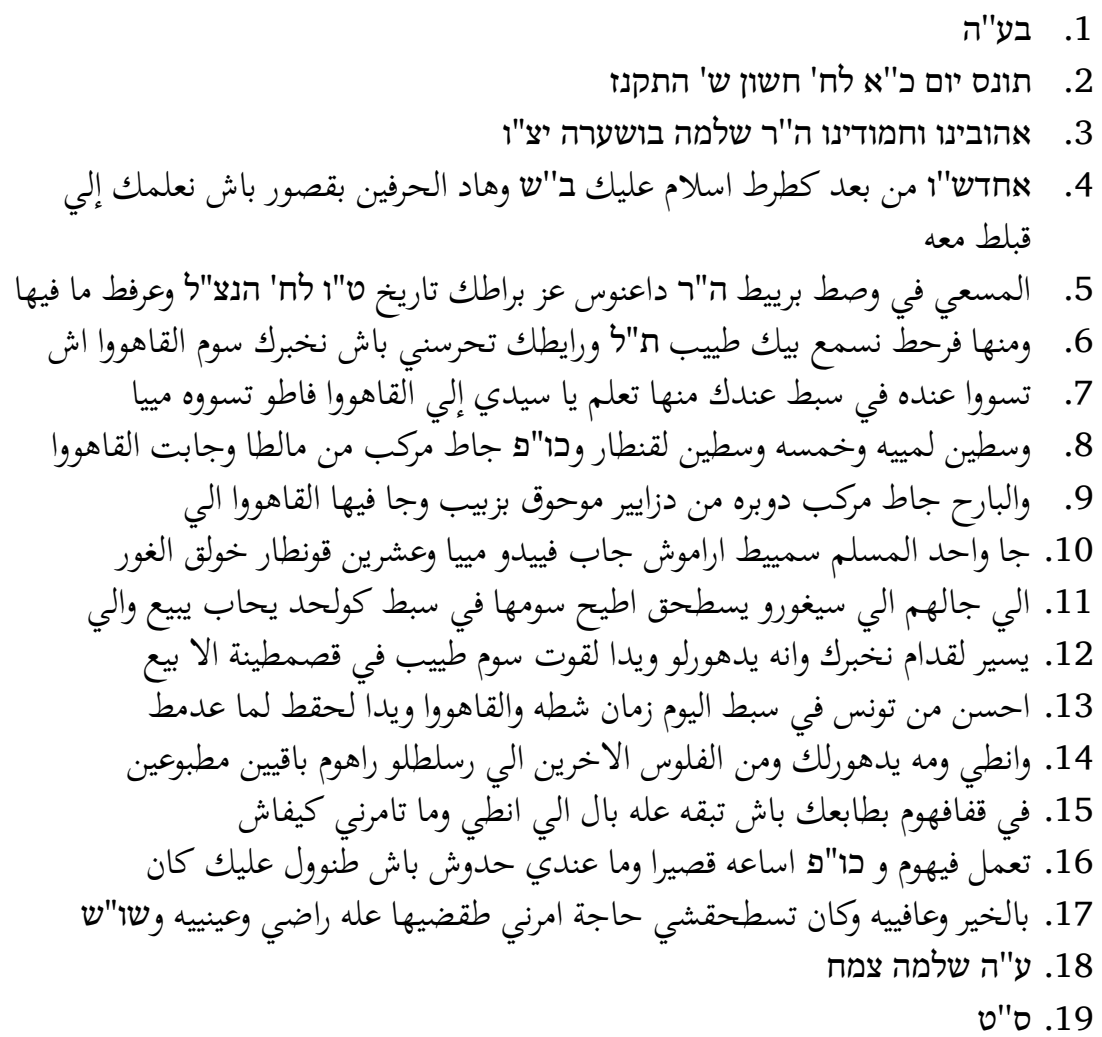

\section{Translation}

(1) With the help of God. (2) Tunis on the 21st of Cheshvan 5557,

(3) Our beloved and dear Rav Shlomo Bush'ara — may his Rock

${ }^{1}$ Although I have provided the direct transliteration 'Bush'ara' in line with that of Richard Ayoun (2010), there is a great deal of variation in transliterations of this surname in primary sources related to HCA $32 / 1208$. For example, in HCA 32/901/276 spellings range from 'Bouchara' (n.48r), 'Bochara' (n.41r), 'Busciara' (n.37r), and 'Bocharra' (n.35r). Most of the papers and letters in HCA/32/1208 appear to have 
keep him and grant him life. (4) Much peace upon you in the name of God. I am sending these two letters in order to briefly inform you that I have received from (5) the messenger in between the letter of the respected Rav Da'nos dated the fifteenth of the aforementioned month and having taken note what's in it (6) and from it, I was happy to learn that you are well (thanks be to God) and your perspective in supervising me so that I should inform you of the sale of what the coffee (7) totals to on Saturday, informing you, sir, that you have ground coffee totalling onehundred (8) sixty and one-hundred sixty-five [reales] per qantar and also the vessel arrived from Malta carrying the coffee, (9) yesterday a Dobra [Ragusan] vessel arrived from Algiers loaded with raisins and had with it the coffee (10) that the Muslim named Aramouche came bringing [with] one-hundred twenty qantar in hand, of inexperienced character (11) he told them surely it is worth granting its sale, on Saturday everyone likes selling and [through] that (12) which was sent we had previously informed you that it appears also for foodstuffs [there is] an agreeable sale in Constantine, (13) it is better selling there than in Tunis on Saturday, it is now wintertime and the coffee also was afflicted when it became unavailable, (14) and letting you know from the money for the others I sent [what] are the remaining balances (15) in their baskets, following your supervision in order to [meet that which] is on your mind and [awaiting] what you direct me to do with how (16) to handle them and also the

belonged to Shlomo Bush'ara and were captured aboard the cargo ship Venus in late-October 1800, after the vessel ran aground in the port of Mahon. 
time is short and I have nothing new in order to prolong [this letter], may (17) you be well and healthy, if there is anything else required command me and I will gladly carry it out, with great care, peace and happiness

(18) Shlomo Șemah, ${ }^{2}$ servant of God

(19) a good Sefardi

\section{Commentary}

The letter features a variety of linguistic elements characteristic of Maghrebi Arabic. These components include the interrogatives äsh (אש//ش) and kifāsh (כיפאש/كيفاش), as well as the conjunction bāsh (באש/باش) and the demonstrative pronoun hād (האד/هاد). ditionally, the author makes use of the common Maghrebi verbal construction 'to be', through the conjugation of رأي in the thirdperson plural (ראהום/راهوم). Șemaḥ’s writing also demonstrates instances of code-switching to vocabulary from Judaeo-Spanish (line 11), and Hebrew (lines 4 and 16).

Another overarching feature within the letter is the author's reference to the potential sale of the coffee 'on Saturday' (lines 7, 11, 13). This arrangement should give readers pause due to the fact that it stands in violation of both biblical and rabbinic injunctions against conducting business on the Sabbath. The two

\footnotetext{
${ }^{2}$ As with the recipient's surname, the transliteration 'Șemah' directly portrays the sender's Hebrew orthography. That said, alternate Latinised versions of the surname surely existed in the late-18th century. One example is the spelling 'Semah', which is attested in the 1784 communal census records of the Livornese Massari (Tribunale dei Massari, vol. 10, f. 388r, Archivio Storico della Comunità Ebraica di Livorno).
} 
Jewish merchants in question therefore likely relied on the assistance of Muslim or Christian trading partners to carry out this transaction. Besides the obvious temporal dimensions of the phrase פי סבט/في سبت, it may also imply the location for the coffee's sale. More specifically, the inclusive tone of Șemah's affirmation in line 12 to the effect that 'on Saturday everyone likes selling', may suggest the existence of a Saturday market (Sūq es Sebt).

\section{Line 1}

'with the help of God' (lit. 'with the help of the Name') (Hebrew).

Line 2

' לחודש = לחנח = 'in the month' (Hebrew).

' שנה = של לשיח 'year' (Hebrew).

Line 3

הרב = ה"ר ה"the master' (Hebrew).

ישמרהו צורו ויחיהו = יצ"ו 'may his Rock keep him and grant him life' (Hebrew; Hacker 2015, 75).

Line 4

lit. 'in His name' (Hebrew).

אחר דרישות שלומו = אחדש"ו 'after inquiring about your (lit. his) health' (Hebrew).

בקצור 'briefly' (Hebrew).

Line 5

ברייט 'letters' (Maghrebi Arabic بريات). 
Line 6

תודה לאל = ת"ל 'thanks be to God'.

Line 7

The term פאטו/فاتو/fatto is possibly a borrowing from Italian via Judaeo-Spanish, more specifically, the past participle of the Italian verb fare 'to make, to do'. Accordingly, the 'made' or 'finished' coffee may indicate that it had already been ground or processed in some manner.

Line 8

lit. 'generally and particularly', but used colloquially as 'also' (Hebrew).

Line 10

This prepositional construction 'in hand' is perhaps a hybridisation of the Hebrew 3ms possessive suffix (1-) and the Arabic preposition (في) with the cognate 'hand' (يد-יד). Furthermore, the mention of خولق الغور/כולק אלגור 'inexperienced character' in this line stems from the likelihood that the merchant Aramouche did not offer the proper valuation for the coffee he brought from Algiers. From another letter we learn that the latter cargo sold for only one hundred forty reales per qantar, while the cargo of coffee from Malta sold for one hundred sixty-five reales per qantar. ${ }^{3}$

Line 11

سيغورو/סיגורו = seguro 'certainly' (Castilian).

Line 16

חדוש 'news' (Hebrew).

3 Shlomo Șemah to Shlomo Bush'ara, 4 Kislev 5557, HCA/32/1208/126.1, British National Archives. 
Line 17

שלום ושמחה = שו"ש 'peace and happiness' (Hebrew).

lit. 'my eyes' is used here colloquially as a parting word of affection that translates to 'with great care'.

Line 18

'servant of God' (lit. 'servant of the Name') (Hebrew).

Line 19

ספרדי טוב = ס"ט 'a good Sefardi’ (Hebrew). 



\title{
23. THE CAIRO-RAMLA MANUSCRIPTS, OR THE RAMLE KAR, 13 (1800S)
}

\author{
Olav Ørum
}

\section{Transcription}

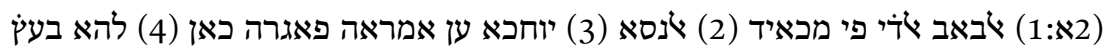

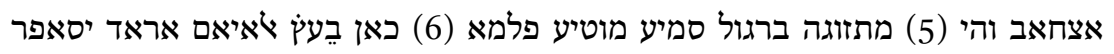

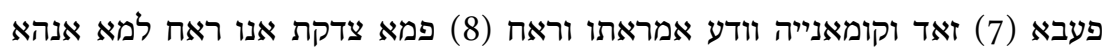

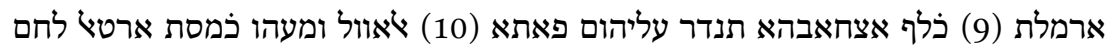

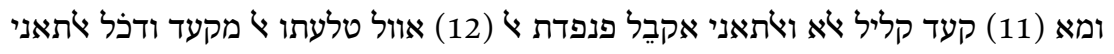

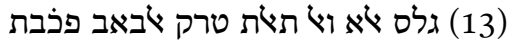

(2:1:) ל תאני פי זיר עארג ודذל ל תלת פמא (2) לחק יגלס לא וץ ראבע טרק לבאב

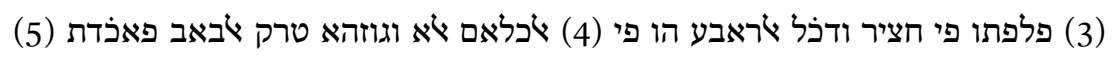

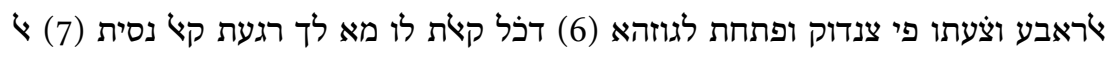

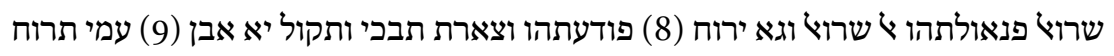

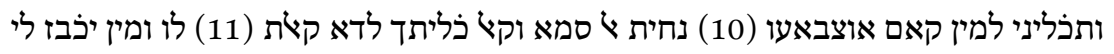

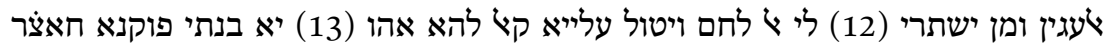

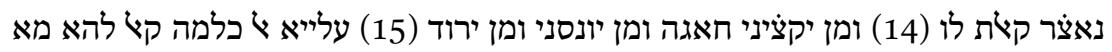
קולת לך ניר יק

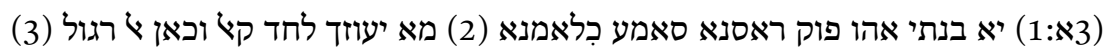

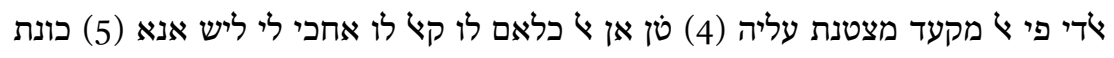

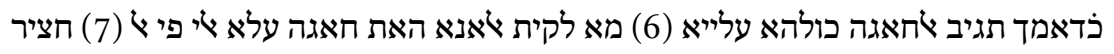

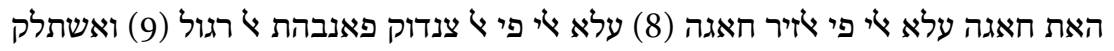

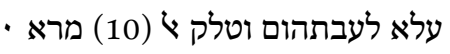




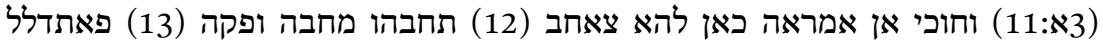

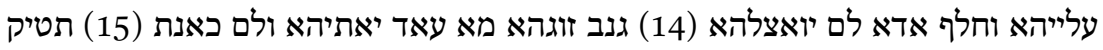
פוראקו פקלת לו ל לילה תעלא יוחל

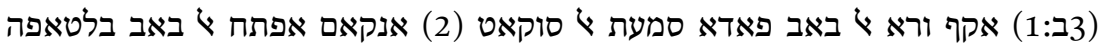

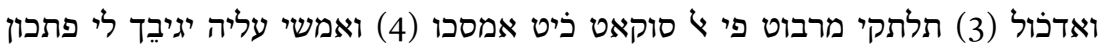

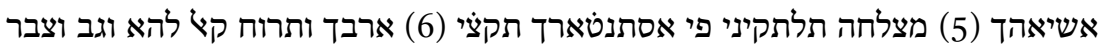

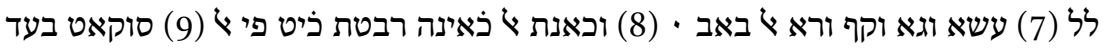

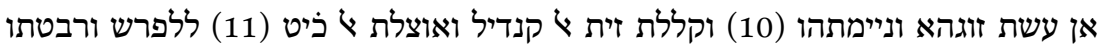

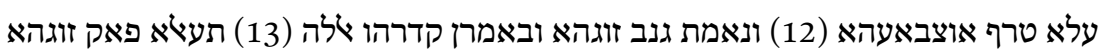

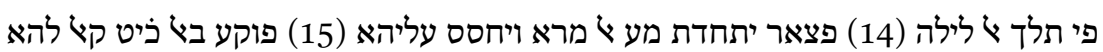
ודא איש יא בהגה

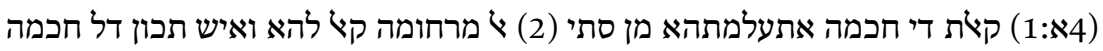

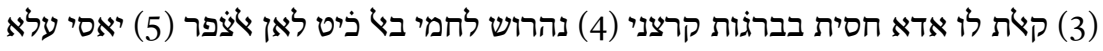

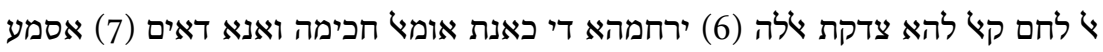

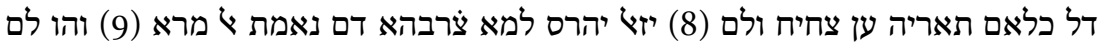

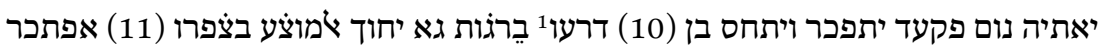

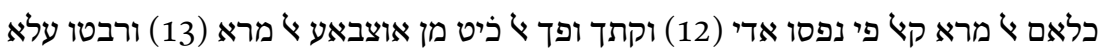

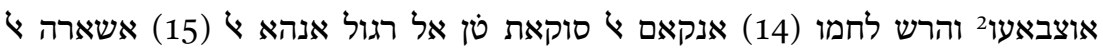

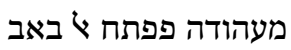

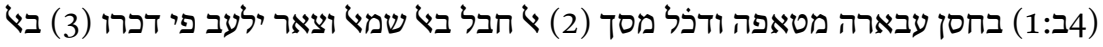

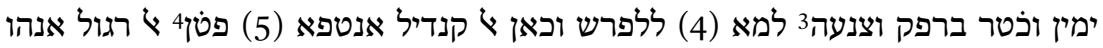

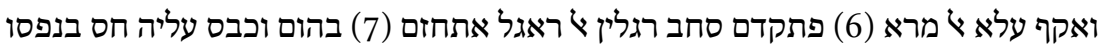

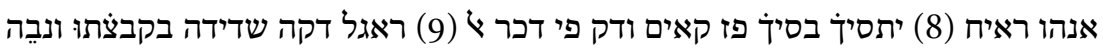

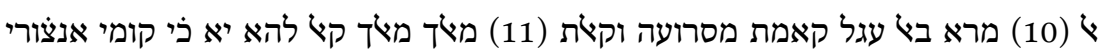

\footnotetext{
1 דרעו; MS: לרעו.

2 ורבטו עלא אוצבאעו MS: ורבטו עלא \& אוצבאעו 2.

3 וצנעה; MS: וצנעה.

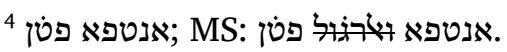




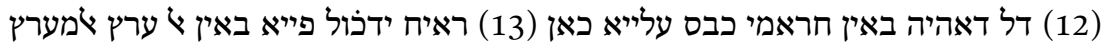

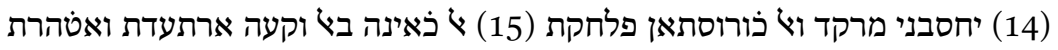

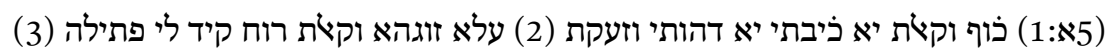

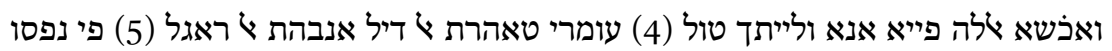

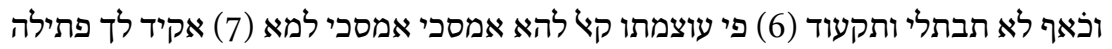

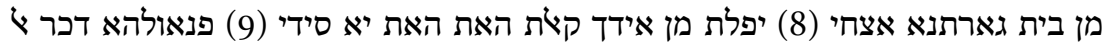

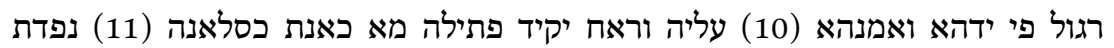

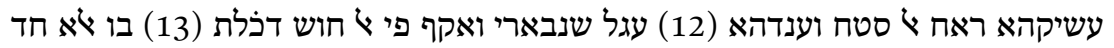

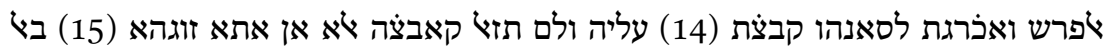

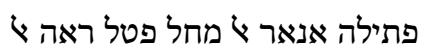

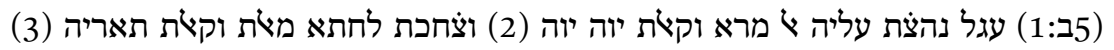

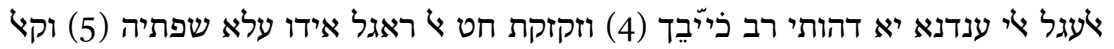

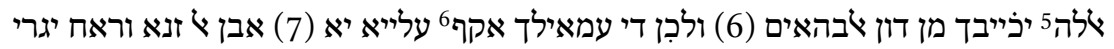

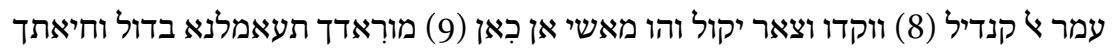

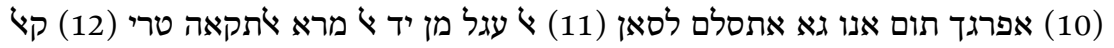

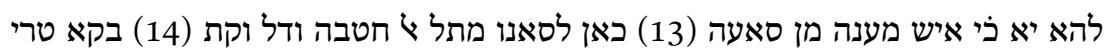

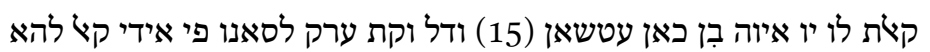

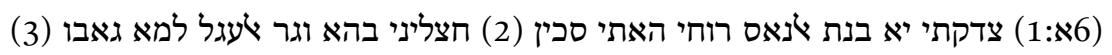

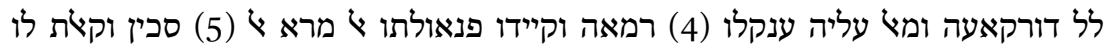

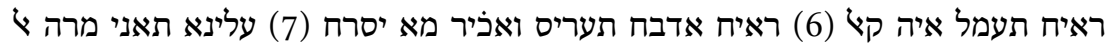

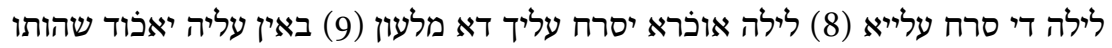

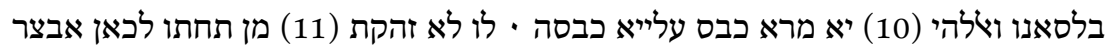

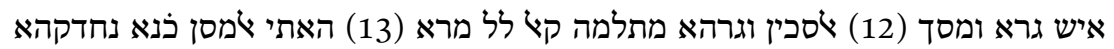

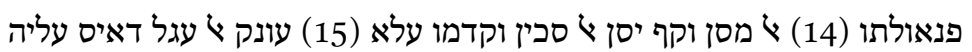

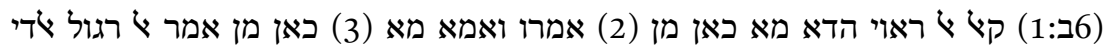

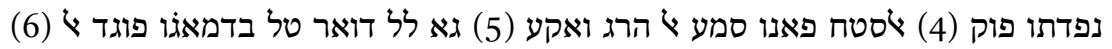

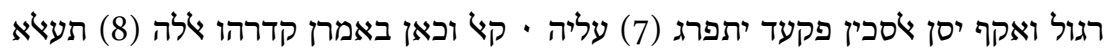

\footnotetext{
5 וקץ אלה MS: וקל קרילאלה.

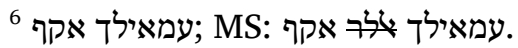


ענדהום כבש פחל פי ל' סטח (9) אתכייל בל רגול אתזאול מנו (10) פאתוכר וחכם צהרו

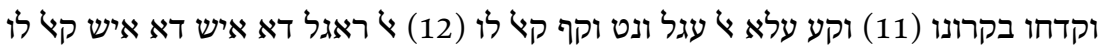

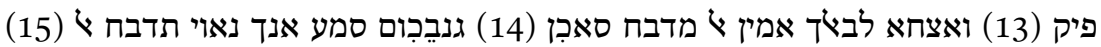
עגל בעתני לך יטלוב מנך ארבע אמין מדוק

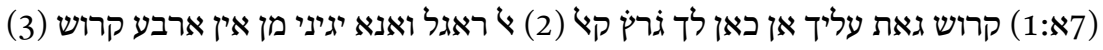

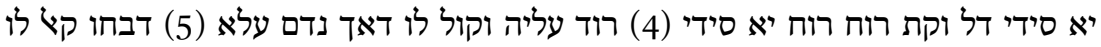

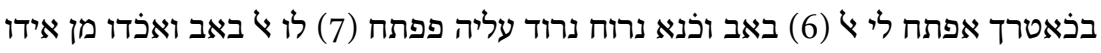
סלכו טלע (8) ראח והדא בעץ פעאילהום (9) תם

\section{Arabic Transcription}

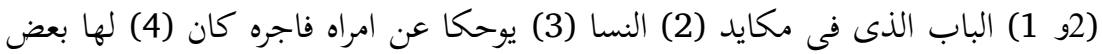

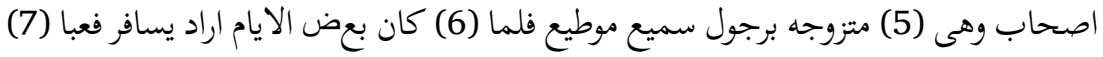

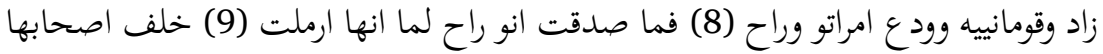

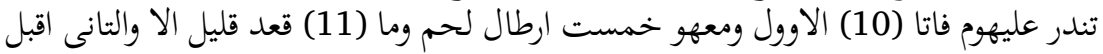

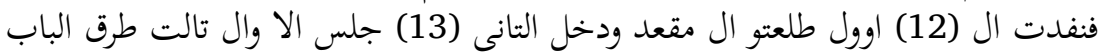
فخبتت

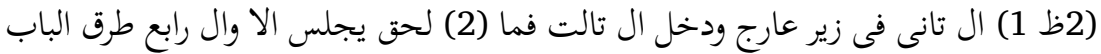

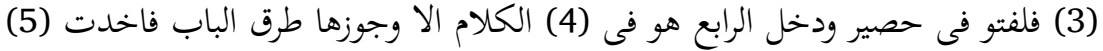

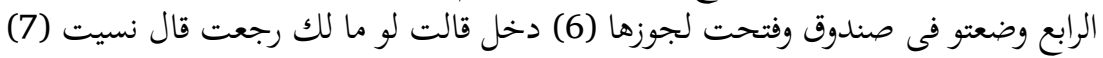

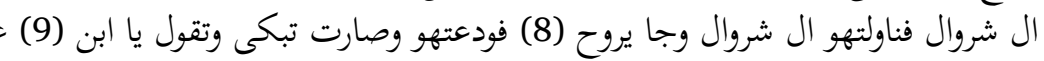

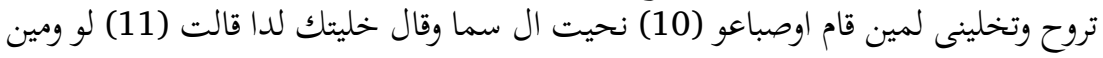

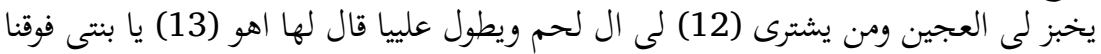

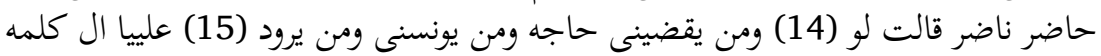

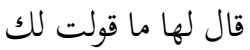

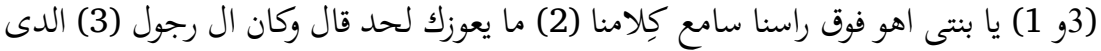

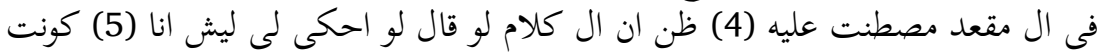

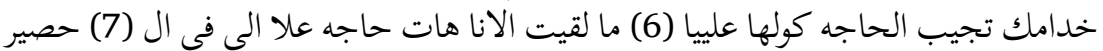

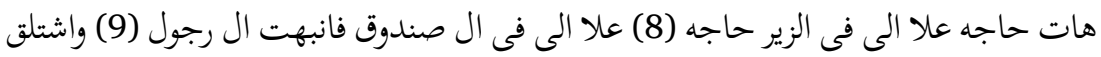

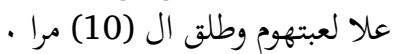


(3و 11) وحوكى ان امراه كان لها صاحب (12) تحبهو محبه وفقه (13) فاتبه (13) فاتدلل علييها

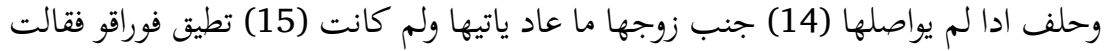

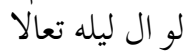

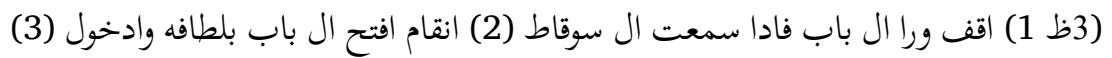

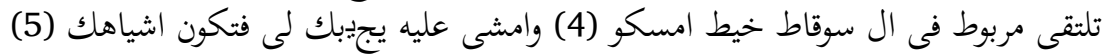

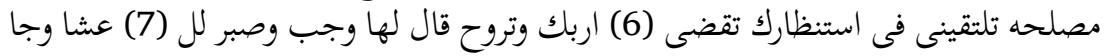

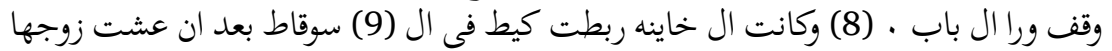

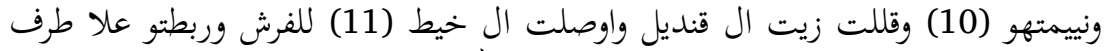

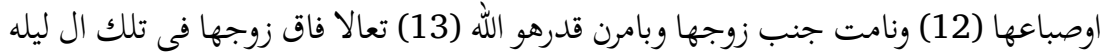

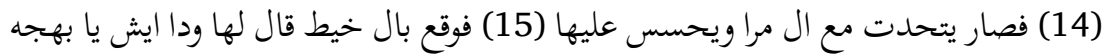

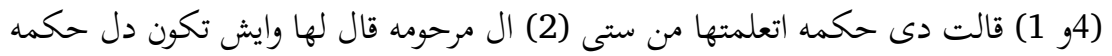

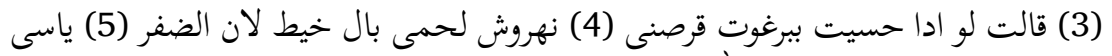

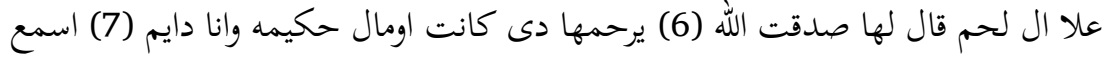

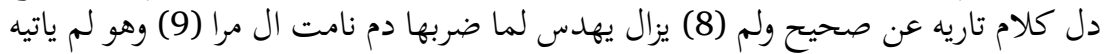

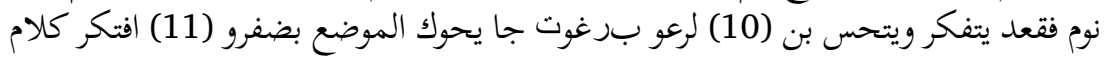

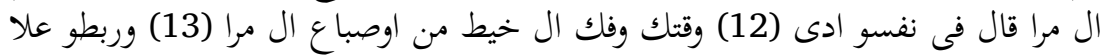

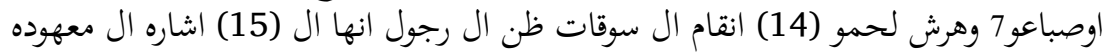
فنتح ال باب أوهرث

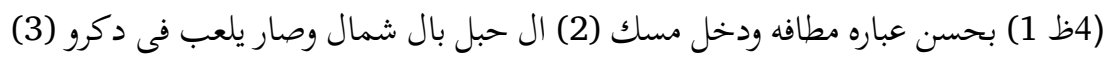

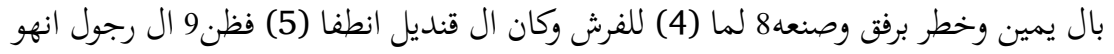

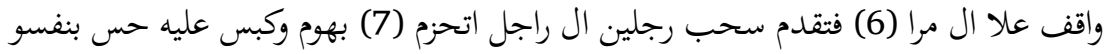

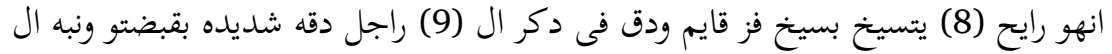

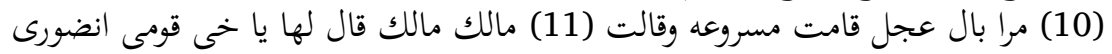

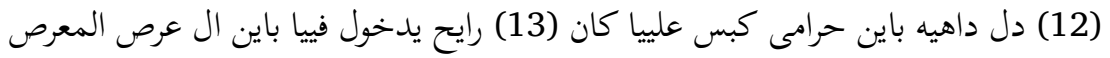

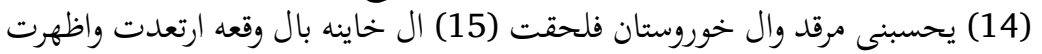

7 وربطو علا اوصباعو; MS: وربطو علا لا اوصباعو

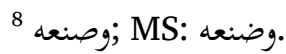

9 انطفا فظن: MS: انطفا والرجول ف فظن. 


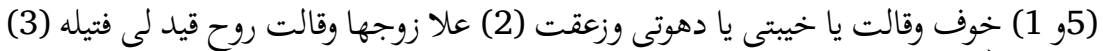

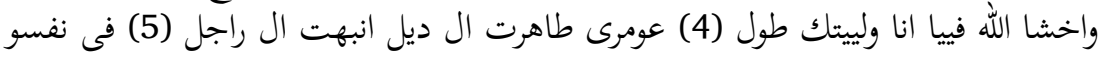

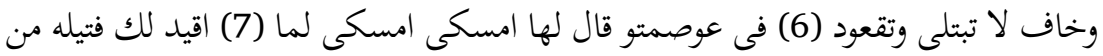

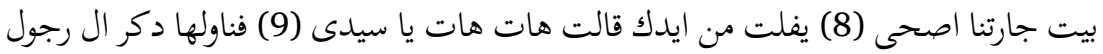

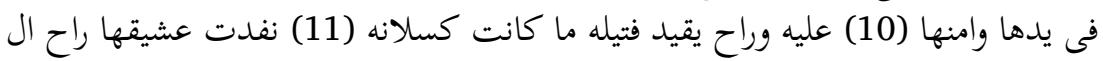

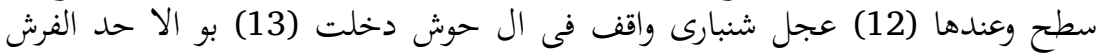

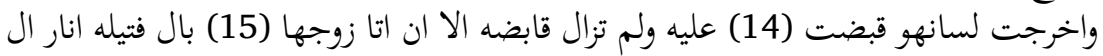
محل فطل راه ال

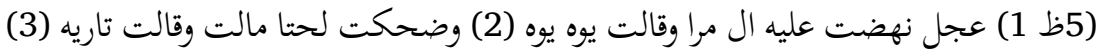

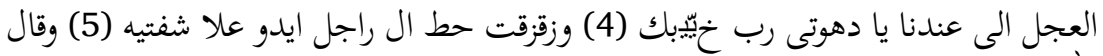

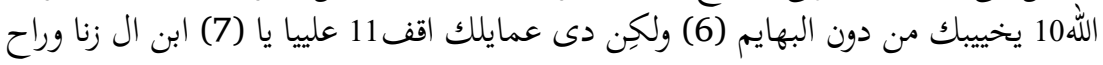

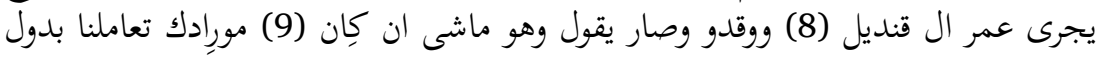

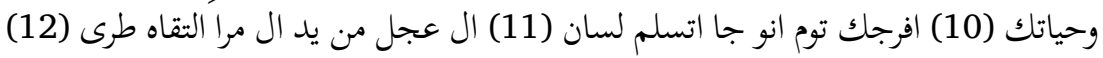

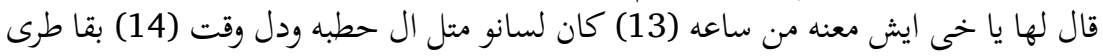

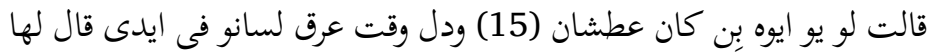

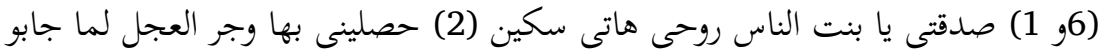

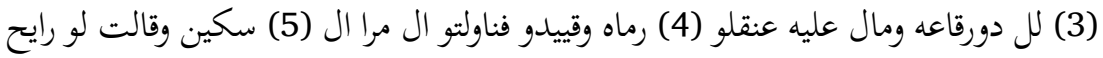

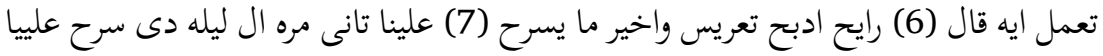

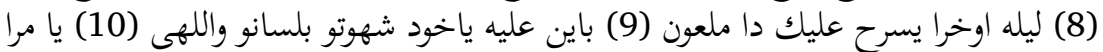

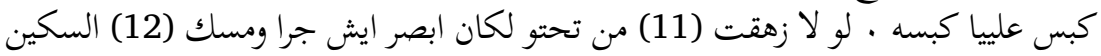

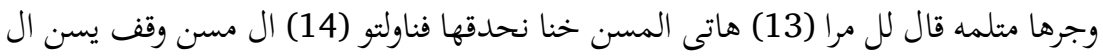
سكين وقدمو علا (15) عونق ال عجل دايس علئ عليه

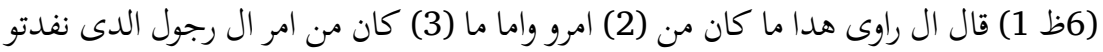

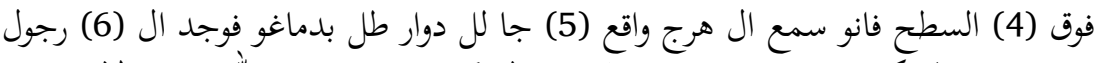

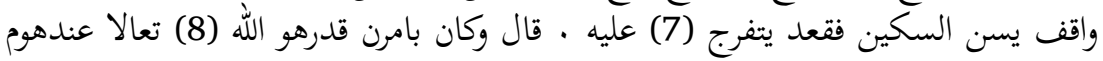

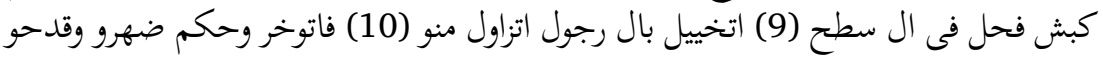

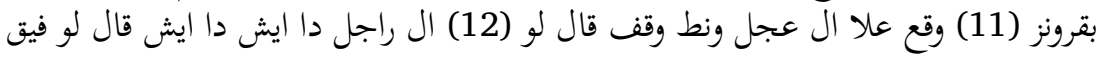

10 زوقال الله : MS: وقال بئى الله :

11 عمايلك اقف; MS: عمايلك اللر اقف. 


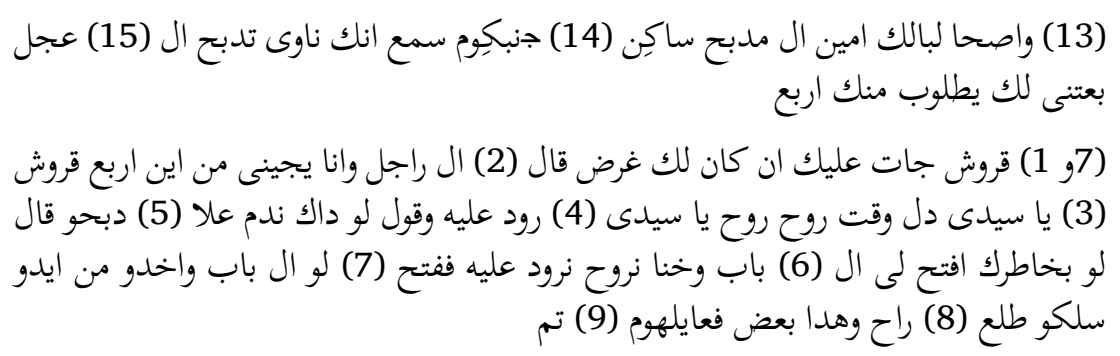

\section{Translation}

(2a:1) The Chapter of the (2) Wives' Schemes.

(3) It has been told about this brazen wife, that she (4) had some male friends while being (5) married to a man of the listening and abiding kind. (6) One day, he wanted to travel, so he packed (7) provisions and supplies, said farewell to his wife and left.

(8) She couldn't believe it [and could hardly wait for him to leave. As soon as he had left], she pretended (9) she had become a widow, and her [male] friends came after her. (10) The first one came, bringing with him five rațls of meat. He hadn't (11) sat for long before the second one approached. So she rushed the (12) first one into the loft room, just as the second one entered. (13) He had barely sat down, when the third knocked on the door. So she hid (2b:1) the second one in a clay pot, and the third one entered inside. He didn't (2) even get time to sit down before the fourth knocked on the door. (3) She wrapped the third in a woven rush mat, and in came the fourth. He had just (4) opened his mouth when her husband knocked on the door. So she took (5) the fourth one, put him in a box and opened up for her husband. (6) "What's the matter with you? You came back," she said when he came inside. "I forgot (7) my trousers," he answered. So she handed him the trousers, and he made a move to 
leave. (8) She said farewell and started crying, saying, (9) "My dear cousin, you are abandoning me! With whom will you leave me?" He pointed his finger (10) in the direction of the sky and said, "I leave you with Him." She answered, (11) "If not you, then who'll bake me dough and who'll buy (12) me meat and accompany me?" (13) "There He is, my girl," he said, "above us, present and witnessing." She said, (14) "Who will do stuff for me? Who will provide (15) me human contact and amuse me? Who will give me answers?" "I told you, (3a:1) my girl," he said, "there $\mathrm{He}$ is, above us, listening to what we are saying. (2) You won't need anyone else!" The man (3) from the loft room upstairs said, (4) thinking the errands were meant for him, "That's unheard of! (5) Am I your servant or something? One who'll bring you whatever you ask for? (6) Haven't you found anyone else but me for doing all this? Give something to the guy inside the (7) mat! And what about giving something to the guy inside the clay pot! And something (8) to the guy inside the box!" So the man finally got it, (9) understood their little game and divorced the wife. (3a:11) And it has been told that there was a woman who had a friend (12) that she loved wholly and dearly. (13) He flirted with her, and swore that if he couldn't have an affair with her (14) when next to her husband, he would not commit to her any more. She couldn't (15) bear being apart from him, so that evening she told him, "Come (3b:1) and stand behind the door. If you hear the door latch (2) move, gently open the door and enter the room. (3) There you'll find a thread tied to the door latch. Grab it (4) and go with it, and it will take you to me and you can 'have yourself (5) a good time.' (?) You will find me waiting for you. 
So do (6) your thing and leave." He told her, "You got it!" He waited for the (7) evening and came to stand behind the door. (8) So the unfaithful one tied a thread to the (9) door latch after she had prepared dinner for her husband and put him to bed. (10) She turned down the oil-lamp and brought the thread with her (11) to bed. She tied it to the tip of her finger (12) and lay down next to her husband. And by the will and power of Allāh(13) may He be exalted-her husband woke up that night (14) and started talking to the wife, touching her a bit. (15) He got caught up in the thread, and asked, "What's that, my dear?" (4a:1) "This is a piece of wisdom, a trick that I learned from (2) my deceased grandmother," she said. "And what be so that piece of wisdom?" (3) he asked. "If I feel a flea biting me, (4) I scratch my skin with the thread. That's because my fingernail (5) will damage the skin." "She was right," he said, "may Allāh (6) protect her. That was a piece of wisdom, indeed! I always (7) listen to those words, and they seem so right!" And (8) he continued to scratch until he started to bleed. While the wife fell asleep, (9) he could not, so he sat up pondering. He felt (10) a flea on his arm. He was about to scratch with his nail, (11) when he remembered what his wife had told him. He said to himself, "Now (12) is your chance!" and untied the thread from the wife's finger (13), tied it onto his own, and scratched his skin. (14) The door latch then moved, and the man outside thought that it was the (15) 'promised' sign. He opened the door, (4b:1) and gently passed inside. He entered, grabbed (2) the thread with his left hand and started playing with his penis (3) with his right hand. Then he proceeded in a proud and elegant manner. When (4) he was next 
to the bed where the oil-lamp had gone out, (5) the man thought that he was standing over the wife. (6) So he pulled the husband's legs around his hips, held (7) them firmly and lay on top of him. The husband got the feeling that he was going to (8) get penetrated, so he jumped up and punched the (9) man in the crouch with a hard fist punch, and (10) quickly alerted the wife. She got up in a hurry and said, (11) "What's the matter with you?" "Get up, my dear! Look!" (12) he replied, "Look at that sly bastard! That criminal lay on top of me and was (13) about to enter inside me! The unscrupulous pig (14) thought I was sleeping, and then the fairy..." (15) The unfaithful one overcame the shock (?), trembled, and appeared to be (5a:1) afraid. "Good Lord," she said and shouted (2) to her husband, saying, "Go and light an oil-lamp wick for me. (3) By the fear of Allāh, I have been your woman all (4) my life and my tale is but pure!" The husband (5) was shocked, and became afraid that this would affect (6) his reputation. He said to her, "Grab this! Grab this! When (7) I light the wick from my neighbour's house for you, be on the alert, (8) let it go from your hand." "Give it to me, give it to me, my dear," she said. (9) So he handed the man's penis in her hand, trusted her (10) with it, made sure she held it strong, and went to light the wick. She reacted quickly (11) and released her lover, who rushed to the roof of the house. (12) She had a beef calf standing in the courtyard which she (13) took inside, next to the bed. She pulled out its tongue and held (14) onto it until her husband came back (15) with the wick. He lit up the place and came to see the (5b:1) calf. The wife came on to him and said, "Well, well!" (2) and laughed until she was tired of laughing, and said, "Actually, 
it was (3) the calf who was here. Good Lord, God damn you!" (4) and chirped. The man put his hand on his lips (5) and said, "May Allāh curse you, that thing was not the cattle! (6) So this what you are doing to me? He was standing over me, you (7) son of a bitch." He rushed over to fix the oil-lamp, (8) lit it, and started moving while saying, "If (9) your intention is to treat [our marriage] like this, I swear by your life, (10) I'll show you!" After that he came and took the tongue (11) of the calf from the wife's hand and found it moist. (12) He said, "My dear, that doesn't make sense! (13) A moment ago, his tongue was like a piece of wood, and suddenly (14) it became moist?" She said, "Boy, o boy, he was thirsty (15) and now his tongue started sweating in my hands." He said, (6a:1) "That's right, oh good girl. Go get me a knife. (2) Give it to me, and drag the calf along with you." When he had taken it (3) to the courtyard, he wrestled it down (4) and threw it to the ground and tied it. The wife gave him (5) the knife, and said to him, "What are you going to do?" He replied, (6) "I am going to slaughter a wedding feast, of the last thing that grazes (7) on us ever again. This night it grazed on me, (8) another night it grazes on you. He is cursed, (9) he who has to take on his cravings with his tongue. (10) Wallah, I swear, o woman, it really squeezed onto me. If I hadn't pulled myself (11) from beneath him, I sure know what would have happened." So he took (12) the knife along with him and told the wife, (13) "Give me the sharpening iron, let's sharpen it." So she handed him (14) the sharpening iron. He stood up, sharpened the knife and brought it to (15) the neck of the calf and pushed down. 
(6b:1) The storyteller has said that this is what happened with (2) the husband. About what (3) happened with the man that she hid on (4) the roof, [it has been said that] he had heard the ongoing chaos, (5) and came back to the house and peaked over the edge with the top of his head. He saw the (6) husband standing there, sharpening his knife, so he sat down and watched (7) him. It has also been said that, by the will and power of Allāh-(8) exalted be He-they had a stud bull goat on the roof. (9) The husband thought he saw something moving on the roof, (10) so the lover, who was on the roof, quickly leaned back. The lover grabbed the goat by its neck and tried to pull it towards the edge of the roof (?), when the goat suddenly pushed him with his horns, (11) and he fell down on top of the calf. He made a jump, standing up, and the husband said to him, (12) "What's this? What's this?" The lover replied, "Wake up! (13) Wake up, the supervisor butcher lives (14) right next to you. He heard that you had decided to slaughter the (15) calf and sent me to you to ask for four (7a:1) qirsh. You have to pay up if you want to slaughter the calf." (2) "And from where will I get four qirsh, (3) my friend?" the man said, "Go, go away now, my friend, (4) go to him and tell him that it is a remorse on (5) his slaughter." He said to him, "Be so kind, open (6) the door for me and let us go and give him an answer." So he opened (7) the door for him, took him by his hand and led him out. (8) So the lover got out and left. And that's some of the things they did.

(9) The End. 


\section{Commentary}

Preliminary note:

The present text seems to have been strongly influenced by the Egyptian or Cairene vernacular, and is most likely representative of the period between the 17 th and the 19 th centuries. ${ }^{12}$ As a general observation, it is relevant to note that the present text exhibits many linguistic characteristics which have already received extensive treatment in the field of Judaeo-Arabic. For example, the Classical Arabic (CA) short vowels $i, a$, and $u$ are frequently rendered in plene script by means of the orthography of the text. Some examples illustrating this practice are כיבתי 'my impostor, swindler' (5a:1); אכיר 'last' (6a:6); ראגל 'man' (passim;

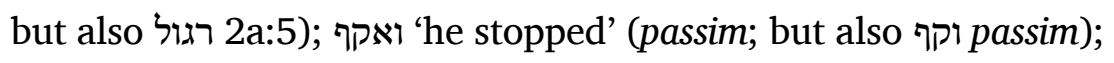
עומרו 'his life' (1b:5); ירוד 'he answers' (2b:14); אוצבאע 'fingers' (passim); יטלוב 'he requests' (6b:15); etc. Not surprisingly, the findings in the present text indicate a stronger presence of plene written the CA short vowel $u$ than of $i$ and $a$. From a morphological and morphosyntactic point of view, one could draw attention to the apparent lack of vowel harmony between word boundaries, viz. 'alayhum < 'alayhim; $h$-less pronominal suffixes, viz. $-u$ $/-\bar{u}(<-\bar{u}(h)<-u h u)$; the seemingly random separation of words, especially concerning the definite article; and invariable

\footnotetext{
${ }^{12}$ This assumption is based on the fact that the MS displays a fragmented short story about Goha/Nasreddin (not included in this sample), whose earliest MS is dated to 1571 . The MS treated here is dated by the National Library of Israel to the 19th century, but it is not clear whether it is a copy of an earlier Vorlage or if it was written down directly from an oral source.
} 
reflections of different pronouns and particles, all of which characteristic of a language variety which some scholars would regard as analytic, or simply as reflecting the style and register employed by the popular or 'lower' strata of the society. Most of these characteristics deviate from CA conventions, and many seem to reflect the actual speech of the social environment in which the text acquired its present shape. Those interested in a more general description of the Judaeo-Arabic language, including the characteristics noted above, may gain further insight by consulting Blau (1999).

2a:1-2

אבאב לדי פי מכאיד לנסא 'The Chapter of the Wives' Schemes; lit. the chapter in which [are found] the schemes of the wives'. An example of $h$-less alternant to CA fihi 'in it' ( $>$ fì $>f i$ ).

2a:6

בעעץ 'some'. Imāla in "inhibiting content" (Cantineau 1960, 23)," reflected in vocalisation. See also אקבל 'he approached' (2a:11); ברגוּות 'flea' (4a:10).

אראד יסאפר 'he wanted to travel'. The expression displays either the hypocorrect absence of the conjunction an, an earlier chronological stage, or a stylistic or social stratum in which the verb 'to want' was represented by the verb arād in speech.

2a:12

'the loft room'. Reflecting the alif-lām ligature and a separate definite article. This occurs passim throughout the MS.

2b:7

שרוץ 'sirwal trousers'. Shift from CA $s$ to š. 
2b:10

ذ' 'I left you with that'. Demonstrative pronoun da.

$2 \mathrm{~b}: 11$

'if not you, then who'll bake me dough?'. Conjunction law + wa-.

$2 \mathrm{~b}: 12$

'that (demonstrative)'. Displaying the intensifying interjection $a$ - (as in أما 'verily, truly, indeed; isn't it'). See also 3a:1.

$2 \mathrm{~b}: 13$

'present and witnessing'. Displaying Islamic content; see, e.g., Mullā ‘Alī al-Qāri’'s Miškāt al-Maṣābịh 10:210.

'witnessing'. De-spirantisation reflected in a shift from CA z (d) to . See also $4 \mathrm{~b}: 11 ; 6 \mathrm{~b}: 10$.

$2 \mathrm{~b}: 15$

מא קולת לך 'I told you (indeed)'. Intensifying particle $m \bar{a}$.

3a:1

כלאמנא 'our words, what we speak of'. A non-standard Modern Egyptian Arabic (MEA) vowel pattern reflected in the vocalisation of short $i$.

3a:3

לדי 'who (demonstrative)'. See also 6b:3; דכרו 'his penis' (4b:2, 8). An apparent de-spirantisation reflected in a shift from CA $\underline{d}$ to $d$. There is also one occurrence of fricative $\underline{d}$ being employed in the demonstrative; however, this is found only in the heading of the chapter (2a:1). 
3a:4

ליש 'why'. Displaying an earlier chronological stage of the more common MEA interrogative variant $l \bar{e}(h)$.

3a:6

' 'who (demonstrative)'. See also 3a:7; 3a:8; 5b:3. Note that the two invariant demonstrative particles changeably throughout the manuscript.

3a:12

wholly and dearly'. See also (possibly) דקה שדידה 'a hard punch' (4b:9). Final - $h$ reflecting the adverbial ending $-a$ or $-\bar{a}$, thus alternating from CA -an. Similar use of final $-h$, when reflecting CA final - $\bar{a}$ (by means of or I), is also attested in מענה 'meaning' (5b:12) and מתלמה 'just as' (6a:12), respectively.

ובאמרן קדרהו אלה 'by the will and power of Allāh'. Use of genitive -in, an ending which here may be considered hypercorrect according to CA conventions. See also $6 \mathrm{~b}: 7$.

3a:14-15

ולם כאנת תטיק פוראקו 'and she couldn't bear being apart from him'. lam + verb in the perfect tense negating a past or completed action.

$3 b: 15$

ודא איש 'what is that?'. Demonstrative pronoun $d a$ preceding the noun. See also 6b:12.

איש 'what'. An earlier chronological stage of the more common, MEA interrogative variant $\bar{e}(h)$.

4a:1

די חכמה 'that is [a piece of] wisdom'. Demonstrative pronoun di. See also 4a:6; 5b:6. 
4a:2

'that [piece] of wisdom'. A merger of the demonstrative with the following definite article, viz. $d$-il- / di-l-. It can be added that it is written separately from the noun which it precedes.

4a:4

נהרוש 'I scratch'. Use of the so-called nekteb-paradigm in the singular. See also 6a:13.

4a:14

סוקאת 'door latch' (but סוקאט passim). De-emphatisation reflected in a shift from CA $t$ to $t$.

4a:16

דאים 'always'. Omitting of adverbial ending ( $-\bar{a}$ and) -an. 4b:7-9

ראיח 'going to'. An earlier chronological stage of the MEA future particle ha / ha by means of the variant rāyih. See also 4b:13; 6a:5; 6a:6.

5a:12

'[shanbar] beef cattle'. Used here in the meaning of MEA kandūz 'meat from a mature buffalo or cow' (Hinds and Badawi 1986, 480, 766).

5b:8-10

' אן כאן מוראדך תעאמלנא בדול 'if your intention is to treat [our marriage] like this (?) [...]'. Demonstrative pronoun $d \bar{o} l$.

אן כִאן מוראדך 'if your intention is'. A double occurrence of the heavy ie-imāla, a feature which has fallen out of use in all modern dialects. It thus represents an earlier chronological stage of the $e$ imāla, which is common in MEA. 
$5 b: 12$

'that doesn't make sense!' Displaying iš (or a variant of it) as a negating particle. ${ }^{13}$

$5 b: 13$

'this time, i.e., now'. The apparent separation of the two items (dil + waqt) reflects an early variant and use of the modern variant dilwa't(i) 'now'. See also 5b:15; 7a:3.

6a:7

'that evening'. Displaying the demonstrative adjective di following the noun.

\section{$6 \mathrm{a}: 13$}

ذנא נחדקהא 'let's sharpen it'. Displaying a shortened variant of the modal auxiliary expression xallina ( $>$ xina) 'let's...'. See also 6b:14.

6b:14

גנבֵכום 'next to you'. Evidence of a slightly palatalised or fronted consonant $k$, viz. " ${ }^{*} a n b^{e} k^{i} u m$.

7a:9

so, let's go and answer him'. Displaying lack of nektebu in the plural (see the use of nekteb in the singular, in 4a:4).

${ }^{13}$ See, e.g., the use of $i \check{\text { ( }}$ (or a variant of it) as a negating particle in Spanish Arabic apud Corriente (1977, 145). 


\title{
24. A 19TH-CENTURY JUDAEO-ARABIC FOLK NARRATIVE ${ }^{1}$
}

\author{
Magdalen M. Connolly
}

The manuscript BnF Hébreu 583² (dated 1839 CE) contains, amongst other material, three Egyptian Judaeo-Arabic (JA) tales, ${ }^{3}$ depicting fictional events in the life of Abraham ibn 'Ezra (c. 1089-1167), the renowned Jewish biblical scholar and polymath. This edition focuses on the third of these tales, in which Abraham ibn 'Ezra, brought from Cairo by two students at the urgent behest of a rabbi, saves the life of the rabbi's son and secures the freedom of the town's Jewish community. While the

1 This short piece is a condensed and updated version of Connolly (2018, 392-420). I am grateful to the University of Uppsala Press for allowing me to reproduce the article, here.

${ }^{2}$ This manuscript was kindly made available to me by the Département de la reproduction at the Bibliothèque nationale de France, Paris. As of 2016, the manuscript is available to view online at http://gallica.bnf.fr/html/und/manuscrits/manuscrits.

${ }^{3}$ These three tales are found in fols $134 \mathrm{v}-140 \mathrm{v}$. The first tale is in fols $134 \mathrm{v}-137 \mathrm{r}$, line 18; the second tale is in fols $137 \mathrm{r}$, line 19-139r, line 18 ; and the third tale-reproduced here- is contained within fols 139r, line 19-140v, line 20. Another version of this tale is found in CUL T-S Ar.46.10. 
literary content of this tale and its socio-historical context ${ }^{4}$ are doubtless worthy of exploration, this short contribution is restricted to a transliteration of the original text, with transcoding into Arabic script, ${ }^{5}$ and an English translation. ${ }^{6}$

${ }^{4}$ Of particular note in this tale is the blood-libel accusation-directed throughout the middle ages at Jewish communities by Christians within Europe and, later in the 1800s, by Syrian Christian communities at their Jewish counterparts. Here, the blood-libel accusation is inverted and levelled against a Christian community. Tensions between Christian and Jewish communities in Egypt and Syria began in the late 17th century, driven by shifts in the political landscape, which-in the case of Egypthad profound economic and social consequences for Cairo's Jewish inhabitants (Masters 2001, 117). The colophon on f. $174 \mathrm{v}$ dates the copying of these tales to Monday, 16th Tevet 1839. It, therefore, predates the infamous 'Damascus Affair' of 1840 by a few months (see Frankel 1997; Masters 2001; and Florence 2004 for details of the 'Damascus Affair'). As such, this text adds another dimension to Master's assertion that blood-libel accusations were circulating among (Syrian) Christian Arabs before the Damascus Affair (Masters 2001, 123). This tale indicates that some Jews were engaging with the accusation and turning it back on their Christian neighbours.

${ }^{5}$ In transcoding the text into Arabic script, I hope to make this JA text, with its many interesting linguistic features, available to a wider audience interested in varieties of Middle Arabic. In so doing, I follow the practice pioneered by Diem (2014) and suggested to me by Dr. Esther-Miriam Wagner (in conversation).

${ }^{6}$ A Hebrew edition of three tales from the manuscript BnF Hébreu 583 was first produced by Yitzhak Avishur (1992). Avishur's interest in the folk narrative appears to have been predominantly literary and 
As is evident in the spelling of consonantal $w \bar{a} w$ and $y \bar{a}^{\text {p }}$ with double vav and yod, respectively, frequent Hebrew lexical items, the occurrence of niktib-niktibu forms, and the consistent separation of the definite article, ${ }^{7}$ this folk narrative contains several features often referred to as characteristic of late JA. These features are found alongside classical JA features, limited CA influence, Middle Arabic practices, and contemporaneous Arabic dialectal features.

From the plene spelling of short vowels and the denotation of the 3ms pronominal suffix with vav to the presence of the colloquial verb $g \bar{a} b$ 'to bring', the fifth form's prosthetic 'alef, and the use of the construct-state particle bita $\bar{a}^{c}$, this text reveals numerous colloquial features that are characteristic of Modern Cairene Arabic. In the presence of the JA relative pronoun, CA-influenced demonstrative pronouns, and complex adverbial subordinators, the text also displays a preoccupation with raising the register above the quotidian, an aspiration which is partially achieved through these aforementioned features.

Furthermore, the use of the diacritical dot and consonantal representation indicate both a continuation of classical JA

historical and his transliteration does not reflect the true state of the text's orthographic features. A new transliteration is, therefore, required for the manuscript to be of use to broader audiences; linguistic as well as literary and historical. This paper serves as a supplement to the existing edition by Avishur, presenting a new transliteration and translation of one of three Egyptian Judaeo-Arabic tales found in the manuscript BnF Hébreu 583.

${ }^{7}$ For a discussion of the separation of the definite article in JA, see Connolly (2021). 
spelling practices_-for example, in the representation of $d \bar{a} d$ with sade and a supralinear diacritical dot, and the enduring, albeit limited, influence of contemporaneous Arabic orthographic practices evident in the application of the diacritic to graphemes such as pe for $f \bar{a}^{3}$, dalet for $\underline{d} \bar{a} l$, and $k a f$ for $h \bar{a}^{\prime}$, in imitation of the physical form of their Arabic graphemic equivalents. ${ }^{8}$

\section{Notes on the Edition}

The text has been as faithfully rendered as possible, including all diacritics and orthographic idiosyncrasies found in the original manuscript. The JA text has then been transcoded into Arabic script, grapheme-for-grapheme. No adjustments or amendments have been made to the text in its transcoded form. As for the English translation, any additions intended to aid comprehension and readability are enclosed in parenthesis ().

\section{Transliteration}

139r.

\footnotetext{
19. איצה אלברו אן כאן פי בלד מן בלאד אל ערלים9 כאנו כל

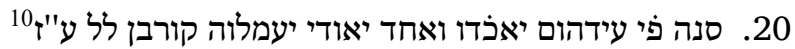

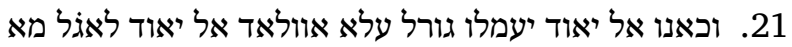

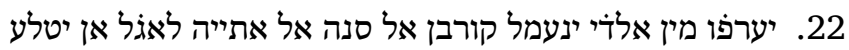

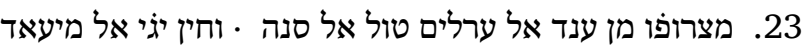

\footnotetext{
${ }^{8}$ On the use of diacritical dots in late JA, see Connolly forthcoming.

9 The term ערלים 'uncircumcised' (sg. עָרֵל ) is used to refer to Christians (Jastrow 2005, 1119).

10 ע"ז: 'idolatry' (עבודה זרה).
} 


\section{9v.}

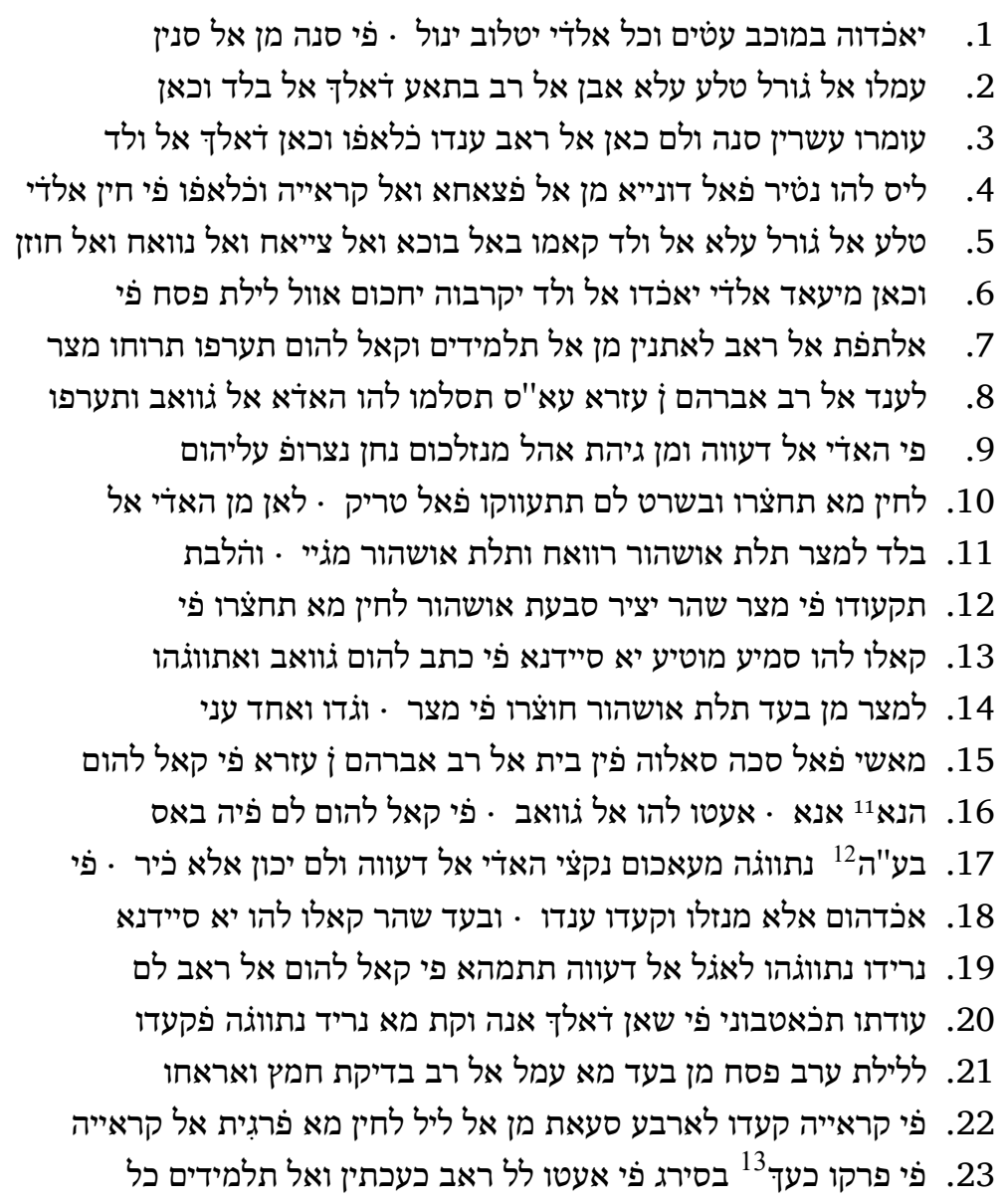

11 This may read הוא 'he' rather than הנא 'Were'.

בע"ה 12 :With the help of God' (בעזרת השם).

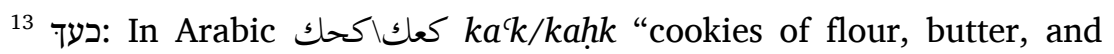
sometimes a sweet filling or a dusting of sugar, baked for special occasions" (Hinds and Badawi 1986, 737). In light of the context in which these 'cookies' are consumed in this tale, however, it is possible that $k a^{c} k$ here refers not to celebratory cookies but to matzōt, the unleavened bread consumed during Passover (see preceding footnote). 
24. ואחד כעכתין ואתווגהו לחאלהום פי אذד טריקו אל רב אذ ‡ עזרא ואל

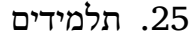

140r.

1. 2. 3. 4. 5. 6. 7. 8.

9.

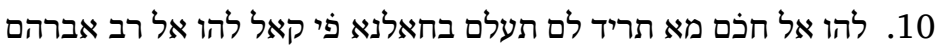

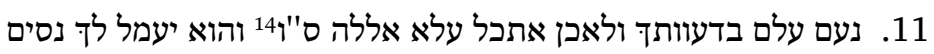

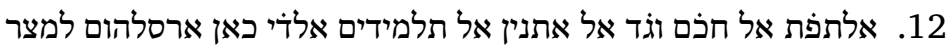

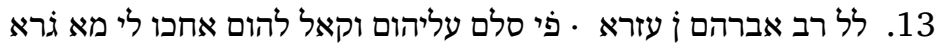

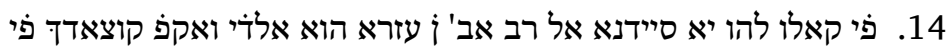

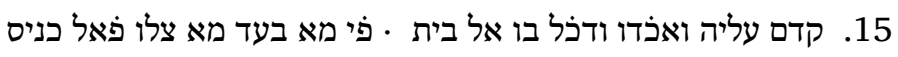

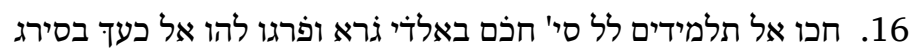

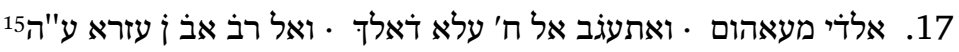

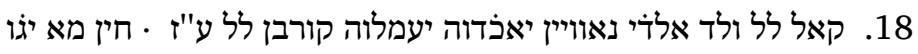

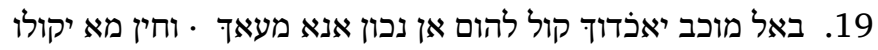

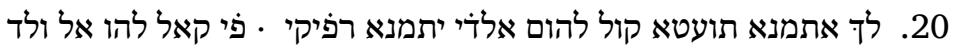

21.

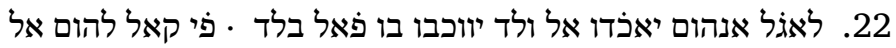

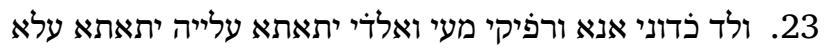

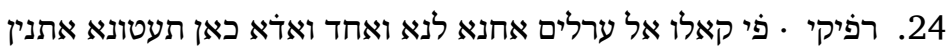

\footnotetext{
ه" 'Praise the Lord!' (سبحان الله ، 14 (20).

15 ע"ה: 'Peace be upon him' (עליו השלום).
} 


\section{0v.}

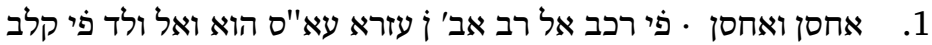
2.

3.

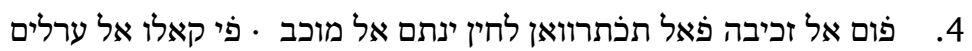

5.

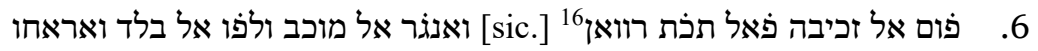
7. 8. 9.

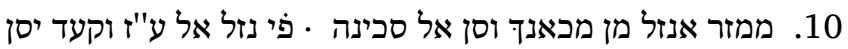

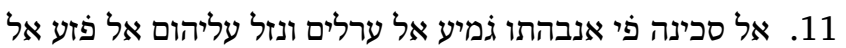

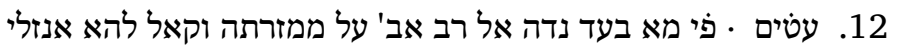

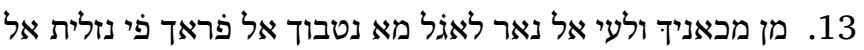

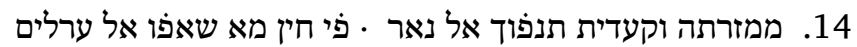

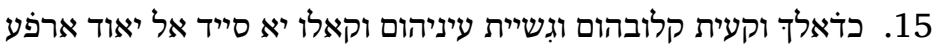

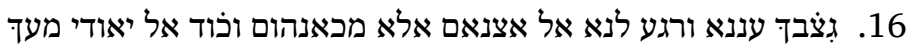

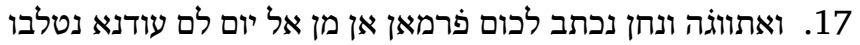

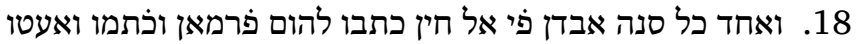

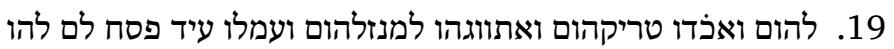

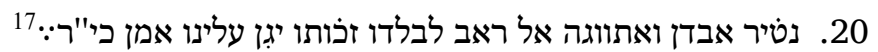

\section{Arabic Transliteration}

139r.

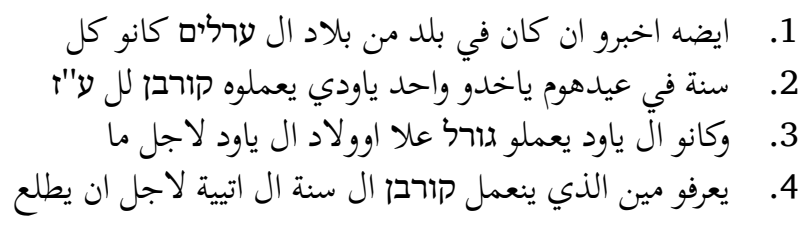

תכת רוואן 16 :sedan chair' is written here in two parts, whereas elsewhere it reads as a single word (תכתרוואן).

17 כי"ר: ‘His will be done!' (כן יהי רצון). 
5. مصروفو من عند ال ערלים طول ال سنة · وحين يجي ال ميعاد

139v.

1. ياخدوه بموكب عظيم وكل الذي يطلوب ينول · في سنة من ال سنين 2.

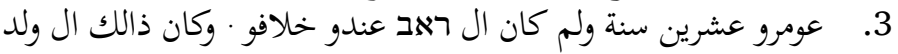

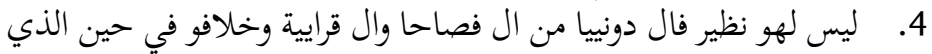

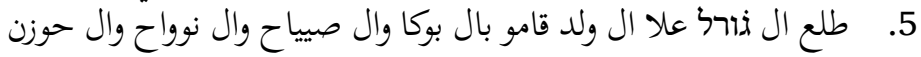

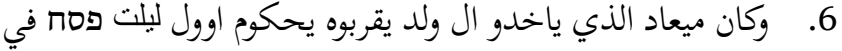

7. 8.

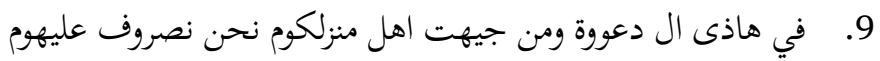

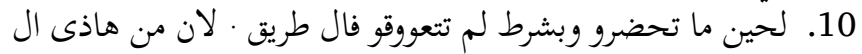

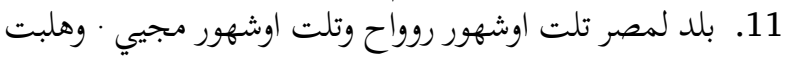

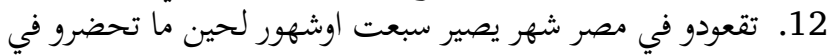

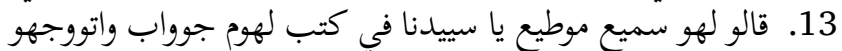

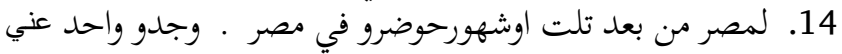

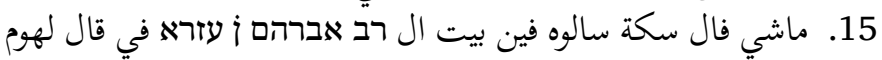

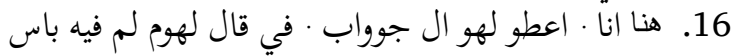

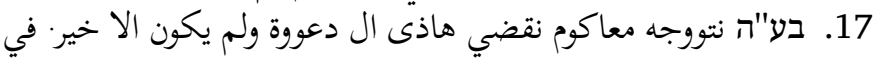

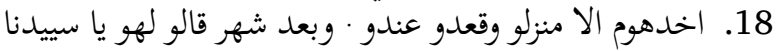

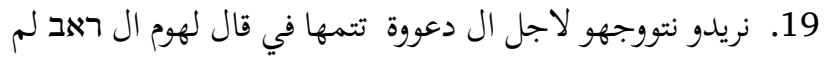

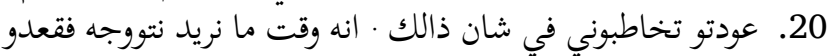

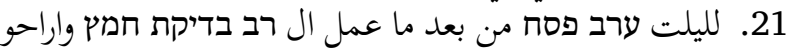

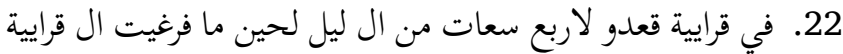

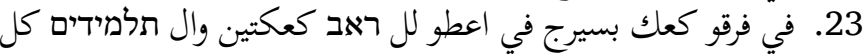

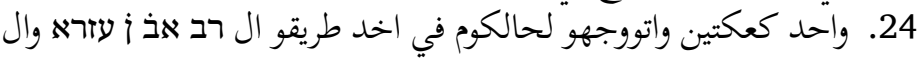
25. - 25. פלמידים كم:

140r.

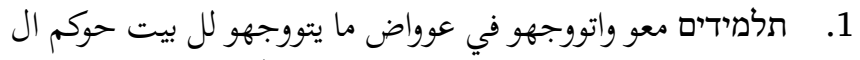

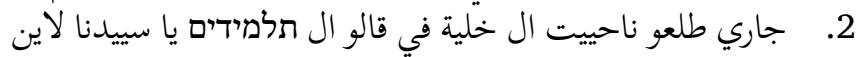

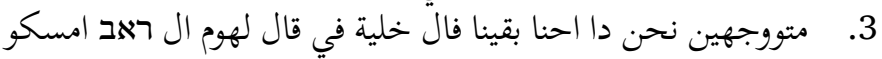


4. في طرفي في مسكو طرفو وقرى שه لم طلع عليهوم ال فجر الا

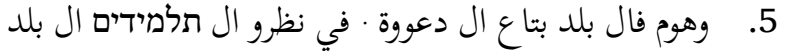

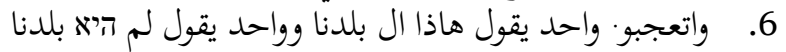
7. 8.

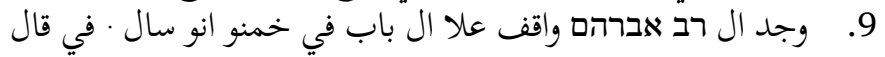

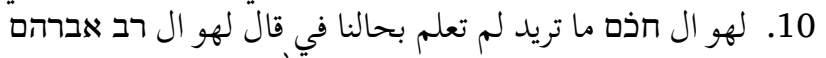

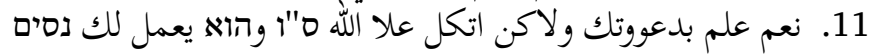

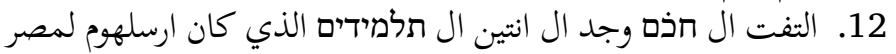

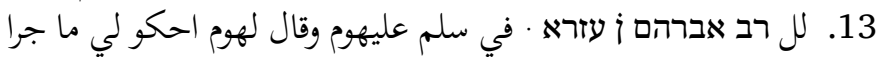

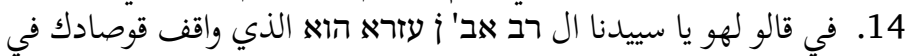

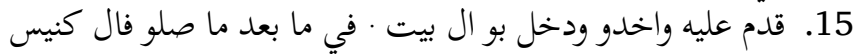

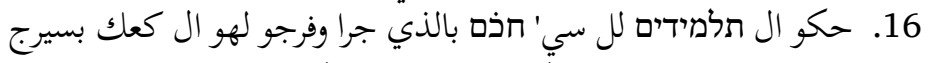

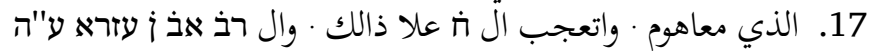

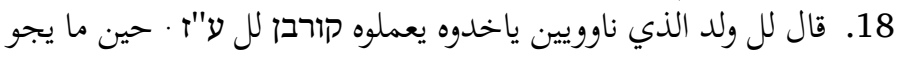

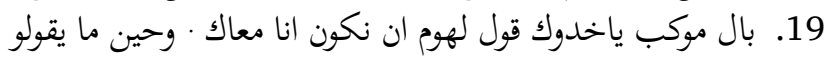

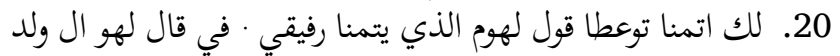

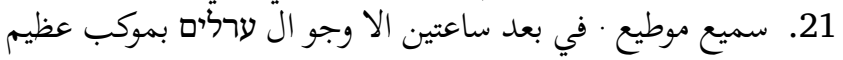

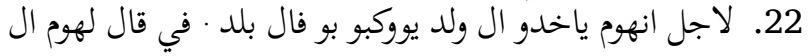

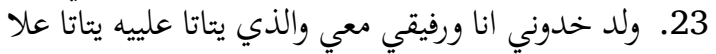

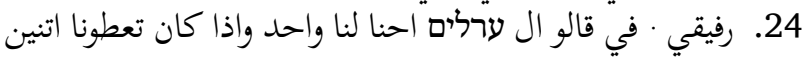

\section{0v.}

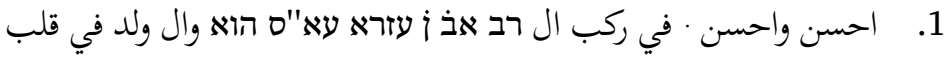

2.

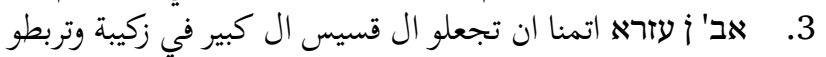

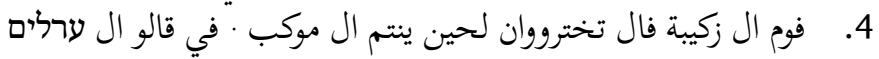

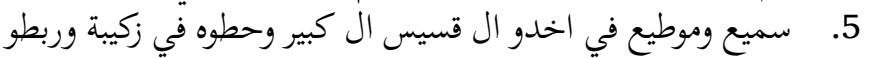

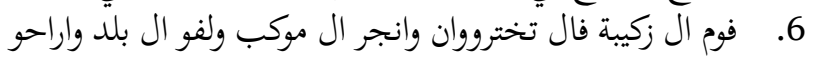
7.

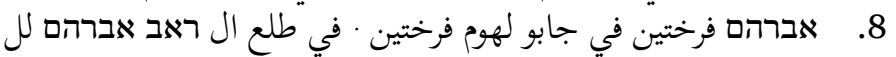

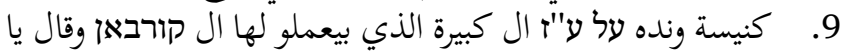

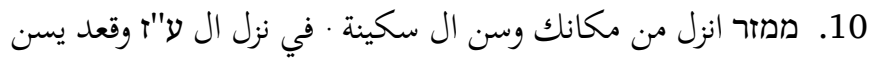

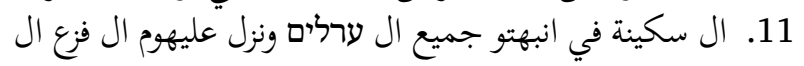




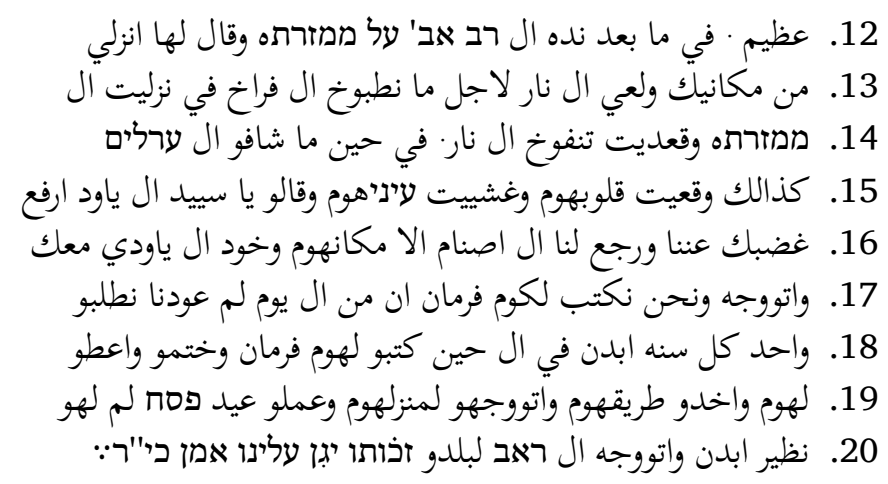

\section{Translation}

\section{9r.}

(19) They also recounted that in one of the towns of the uncircumcised, every (20) year during their feast day, they would take one of the Jews, making him a sacrifice for the(ir) idols. (21) (Every year,) the Jews would cast lots for the children of the Jews in order that (22) they might know who would be made a sacrifice the following year, so that he might take (23) his expenses from the uncircumcised during the (remaining) year. When the appointed time came,

\section{9v.}

(1) they would take him in a great procession, and all that he asked for would be granted. One year, (2) they cast the lot, (and) it fell on the son of the rabbi of that town. He was (3) twenty years old and the rabbi had no other (children) besides him. This boy had (4) no equal in the world in terms of eloquence and the recitation (of the Torah), and so on. When (5) the lot fell on the boy, they began weeping, wailing, mourning, and grieving. (6) 
(The) date on which they would take the boy and present him as a sacrifice was decided as the first night of Passover. (7) So, the rabbi turned to two of (his) students, saying to them, "You know you will go to Cairo, (8) to the place of Rabbi Abraham ibn 'Ezra, peace be upon him! You will deliver this letter to him and you will inform (him) (9) of this appeal. As for the people of your home(s), we will support them (10) until you return ${ }^{18}$ and on the condition that you do not tarry on the road. From this (11) town to Cairo it is three months going and three months coming back. No doubt (12) you will stay in Cairo for a month. It will, thus, be seven months until you return." (13) They replied, "We hear you and are obedient, $\mathrm{O}$, our master." So he wrote a letter for them and they set off (14) for Cairo. After three months, they arrived in Cairo and they happened upon a poor man (15) walking along the sidestreet. They asked him, "Where is the house of Abraham ibn 'Ezra?" He replied, (16) "Here I am!" They gave him the letter. Then he said to them, “There's nothing for it! (17) With God's help, I will come with you and I will answer this appeal and all will be well." He then (18) took them to his home, (where) they stayed with him. After a month, they said to him, "O our master, (19) we wish to go so that you can see to the appeal." The Rabbi replied, "You should (20) no longer address me with regard to this matter. I will go when I see fit." So, they stayed (21) until

\footnotetext{
${ }^{18}$ I am grateful to Dr. Nadia Vidro for her suggested translation of this sentence.
} 
the night of the eve of Passover. After the Rabbi did the chametz ${ }^{19}$ check, they went (22) for recitation. They sat for four hours during the night until the recitation was finished. (23) Then, they distributed the $k a^{c} k$ with sesame oil. They gave two $k a^{c} k$ to the Rabbi and two $k a k$ to each of the (24) students. Then, they set out to (tend to) their business. Rabbi Abraham ibn 'Ezra went on his way, and the (25) (catchword)

\section{0r.}

(1) students accompanied him and they set off (together). Instead of going to the house (from which) the current (2) decree (came), they went off in the direction of the wilderness. The students exclaimed, "O, our master, where (3) are we going? This (seems to us like) we are still in the wilderness!" The Rabbi replied, "Stay (4) close to me." So they stayed where they were. He called out a Name (but) not till dawn broke over them (did they realise that) (5) that they were in the town from which the appeal came. The students saw the town (6) and were astonished! One (of them) said, "this is our town!" But the other exclaimed, "this is not our town, (7) we're (still) in Cairo!" Rabbi Abraham walked in front of them until they arrived at the house of the (8) sage. They

${ }^{19}$ Chametz refers to food that contains grains which have been mixed with water, and left to rise. In Judaism, it is forbidden to eat any products containing chametz from the day before Passover until the end of Passover. During this period, only matzōt (unleavened bread) is consumed. On the day before Passover, all chametz food must be removed from the house, hence, the 'chametz check'. 
knocked on the door. The sage came down, (and) opened the door (9) and found Rabbi Abraham standing on his doorstep. The sage assumed that he was a beggar, so he (10) said to him, "What do you want? Do you not know of our situation?" Rabbi Abraham replied, (11) "Yes, (I) know about your appeal, but you should trust in God, He is exalted! He will perform miracles for you!" (12) The sage turned and found the two students whom he had sent to Cairo (13) (in search of) Rabbi Abraham ibn 'Ezra. He greeted them and said to them, "Tell me what happened!" (14) They replied, "O our master, it is Rabbi Abraham ibn 'Ezra who stands in front of you!" So (15) he introduced himself and they took (him along with them) and he entered the house. After they had prayed in the synagogue, (16) the students told the master, (the) rabbi, about what had happened, and they showed him the $k a^{\prime} k$ with sesame oil, (17) which (they still had) with them. The rabbi was amazed at this. (Meanwhile,) Rabbi Abraham ibn 'Ezra-may God help him-(18) spoke to the boy who was intended to be taken, and made an offering to the idols, "When they come (19) in the procession to take you, tell them that I will be with you. And when they say (20) to you, '(whatever) you wish for, you will be granted', say to them, 'what(ever) my companion desires." The boy replied, (21) "I hear (and) am obedient." After only two hours, the uncircumcised came in a great procession (22) in order to seize the boy (to) parade him through the town. The boy said to them, (23) "Take me and my companion with me, and what(ever) is done to me, shall be done to (24) my companion." The uncircumcised replied, "We have one (already), but if you have given us two, 


\section{0v.}

(1) so much the better!" So, Rabbi Abraham ibn "Ezra rode, along with the boy, in the middle of (2) the sedan chair. The uncircumcised said to them, "(Whatever) you wish for, you will be granted," to which Rabbi (3) Abraham ibn "Ezra replied, "I wish you to put the high priest into a large gunny sack and bind (4) the opening of the sack to the sedan chair until the procession is over." The uncircumcised said, (5) "We hear and are obedient." So they took the high priest, lowered him into a sack, and tied (6) the opening of the sack to the sedan chair. The procession was swept along as they went around the town. Then they went (7) (to) the church. They asked them, "What do you want to eat?" Rabbi Abraham ibn 'Ezra asked them (8) for two chickens. So they brought two chickens for them. Then Rabbi Abraham went into the (9) church and he summoned (the) large idol(s) to which they made the sacrifice(s). He said, "O, (10) bastard! Get down from your place and sharpen th(is) knife!" The idol got down and sat, sharpening (11) the knife. All of the uncircumcised were speechless and great fear descended upon them. (12) Afterwards, Rabbi Abraham ibn 'Ezra summoned his (i.e., the male idol's) female bastard, saying to her, "Get down (13) from your place, and kindle the fire, so that we may cook the chickens!" The female idol (14) descended and sat, blowing (on) the fire. When the uncircumcised saw (15) this, she stilled their hearts and darkened their eyes. They exclaimed, "O, lord of the Jews, dispel (16) your anger towards us and return the idols to their places for us, take the Jew with you, (17) and go! We will write an edict for you 
that from today we will never again claim (18) one (of your people), each year." Then, they wrote an edict for them, signed (it), and gave (it) (19) to them. Then they went on their way, setting off for their home, (where) they made a Passover festival, the like of which (20) had never been seen. Then, Rabbi Abraham ibn 'Ezra returned to his town. May His virtue protect us! Amen. His will be done! 



\title{
25. LIBYA 1: ḤASAN AL-FAQĪH ḤASAN'S CHRONICLE AL-YAWMIYYĀT AL-LİBIYYA (EARLY 19TH CENTURY)
}

\author{
Jérôme Lentin
}

\section{Transcription}

According to al-'Usțā and Juḥaydar (eds) ([1984] 2001, 1:534) يوم الاربعاء با ذي الحجة بـ با هـ توجه' محبنا الحاج مصطفى بن موسى الى سانية القنصل وكتب سدتو انقليز وجاء القنصل

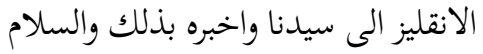
يوم السبت 7 ا ذي الحجة بـع أهـ

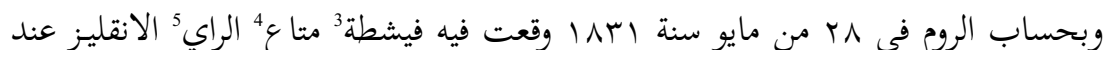

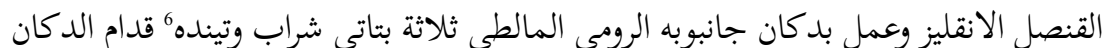

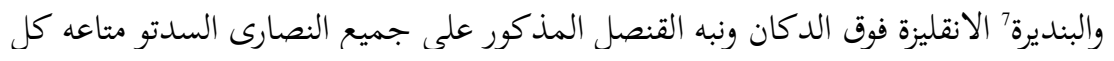

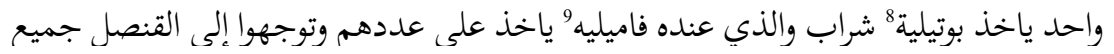

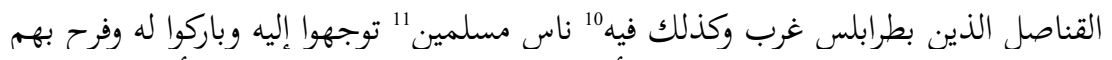

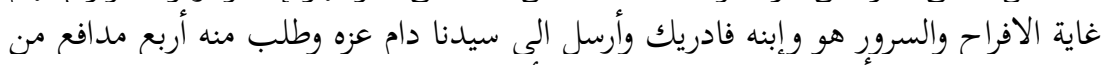

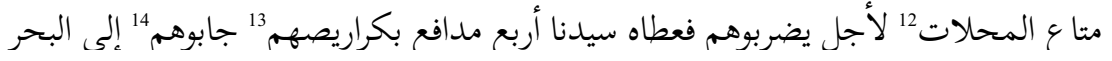

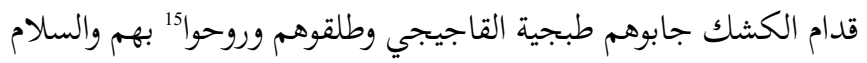




\section{Translation}

Wednesday 13 dū al-hijja 1246 h.

My dear friend the hạjjj Muṣțafā b. Mūsā went to the garden (?) of the consul and registered as an English subject. The English consul went to inform our Lord of that. And that's all.

Saturday 16 dū al-hijja 1246 h [corresponding to] 28 May 1831 in the European calendar.

On that day there took place a party for the King of England at the consul's residence. He had three barrels of wine put in the shop of the Maltese Christian Gian Buba (?), an awning in front of the shop and the English flag over the shop. The consul warned all the Christians [lit. 'his subjects'] that every single person should take [only] one bottle, every man with a family should take according to their number [i.e., the number of the members of the family]. All the consuls who were in Tripoli of the West went to the consul's. There were also Muslims who went to him and presented their compliments to him, which delighted him and his son Frederic very much. He sent a message to our Sovereignmay his glory endure-asking him to send four ceremonial cannons [lit. 'of the embellished type'] to fire them. Our Sovereign gave him four cannons with their carriages. They were taken to the sea-side in front of the pavilion [which towers over the Pasha's palace] by the gunners of Al-Qājijīi. They fired the cannons and brought them back. And that's all. 


\section{Commentary}

${ }^{1}$ The verb توجّه (الى) 'to go (to)', used three times in this short passage, is common in MA texts; it can be considered the 'stylistically elevated' correspondent of rāh (cf. text II.9, no. 4).

2 السدتو cf. Ital. suddito, Sp. súbdito. The chronicle of Ḥasan alFaqih Hasan is rich in borrowings from Romance languages (cf. the notes to $\operatorname{lns} 3,5-9$, and 13 below). No attempt is made here to determine their precise origin, and the references to Spanish (Sp.) or Italian (Ital.) are purely indicative, since these words may have been borrowed from various Italian or Spanish dialects or, more likely, in certain cases at least, from the Lingua Franca.

فيشطة cf. Ital. festa, Sp. Fiesta.

${ }^{4}$ مت colloquial genitive particle. It is attested from the 12th c. in Maghrebi MA texts.

الراي cf. Ital. rè, Sp. rey.

تينده cf. Ital. tenda, Sp. tienda.

7 بنديرة cf. Ital. bandiera, Sp. bandera.

8 بوتيلية cf. Ital. bottiglia, Sp. botella.

9 cf. Ital. famiglia, Sp. familia.

10 في fi / fih 'there is'. Well known in Levantine dialects, but is also used in some (Eastern) Maghrebi dialects.

11 مسلمين. For -in, see text II.9, no. 13.

محلات m(U)hallät (root ḤLW/Y). The editors understand محلات 12 'places' and gloss mutanaqqila 'movable, transportable'.

مروصة plur. of. Ital. carrozza, Sp. carroza.

14 جابوهم. See text II.9, no. 18.

${ }^{15}$ روحوا rawwahūu. See text II.9, no. 4. 



\title{
26. LIBYA 2: LETTER FROM ĠŪMA \\ AL-MAḤMŪDĪ (1795-1858) TO 'AZMİ BĒK, DAFTARDĀR OF THE 'IYĀLA \\ (PROVINCE) OF TRIPOLI (UNDATED)
}

\author{
Jérôme Lentin
}

\section{Transcription}

According to Ibrāhīm (1983, 222-23)

الحمد لله وحده وصلى الله على سيدنا محمد واله وسلم

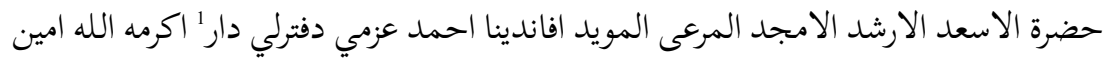

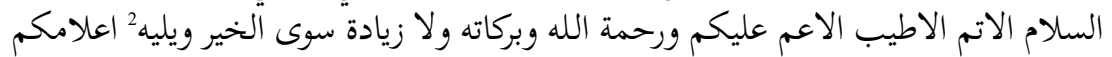

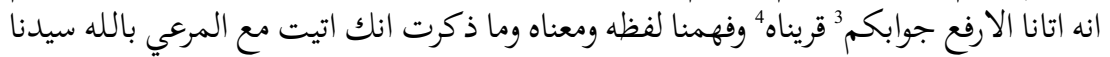

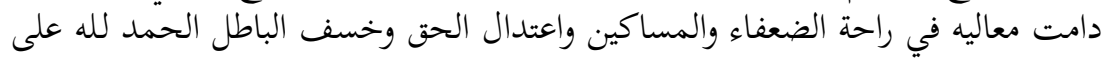

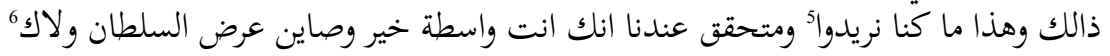

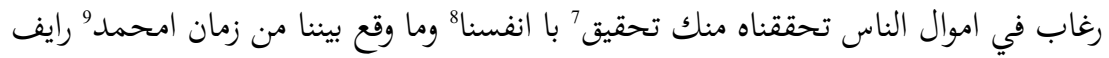

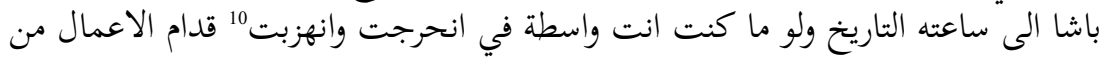

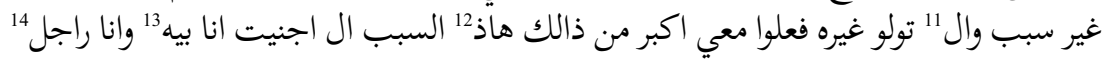

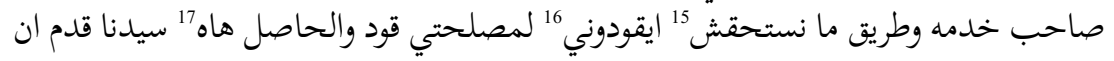

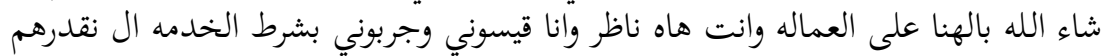

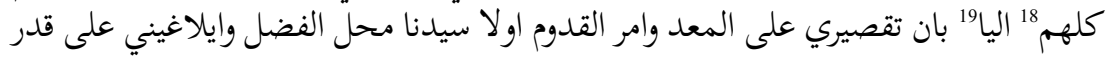

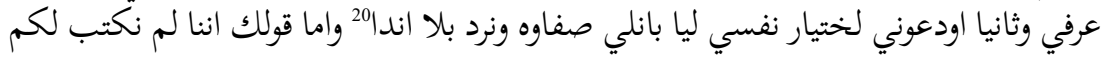

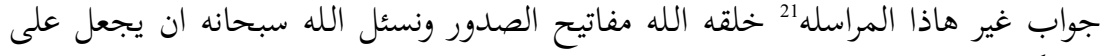

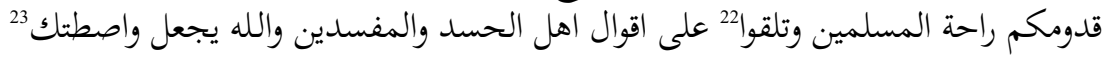




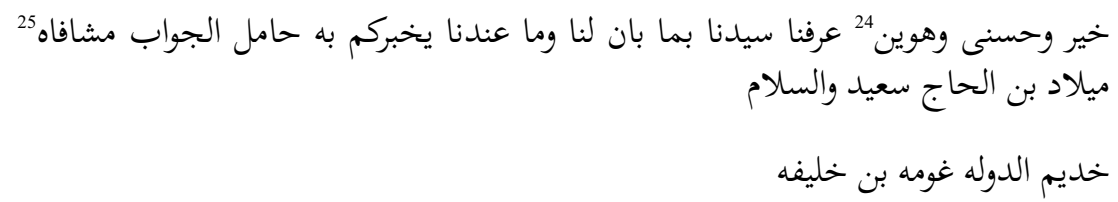

\section{Translation}

God be praised, only Him, and let Him bless our sayyid Muhammad and his family and grant them salvation.

Excellency, felicitous, well-guided, glorious, protected and supported, our 'afandī 'Ahmad 'Azmī, daftardār (director of the financial administration of the province)-may God confer honours upon him. Amen-My fullest, best and most complete greetings to you, may the mercy of God and His blessings be upon you. Nothing is to be added, except [wishes for] the very best. Now, let me inform you that I received your precious letter, that I read it and understood its form and content, as well as what you said about what you did, with our Lord the protected by God-may his noble actions endure-for the comfort of the weak and the poor, and to raise truth and make falsehood vanish. God be praised for that, this is what I wanted. I am assured that your mediation is for the best, that you are the guardian of the Sultan's honor, and that you are not coveting the properties of the people. Of this I have become truly convinced myself from what has happened between us since the time of Muhammad Rāyif Bāšā until this very day, even if you were not mediating for me [at that time, when] I was put on the spot and put to shame in front of the Administration of Finance without any reason. And those who took charge after him did even worse to me. That is why I was blamed [for a crime I had not committed], whereas I am a 
devoted and upright servant, and I don't need to be guided in the performance of my duties. In short, here is our Sovereign who came-let's hope-for the good of the 'amāla (governorate) and here you are, [his] nādir (superintendent). As for me, evaluate me and test me, on one condition: if it appears that, among all the tasks I can accomplish, I have failed to achieve the assigned one, and if I am summoned, first, it will be by our eminent Sovereign and he will treat me according to my abilities; second, let me choose by myself and, if it appears evident to me that he is sincere [in blaming me], I will start again without being asked to. And when you say that I did not write any letter to you except this correspondence... God's human creatures have the key of hearts. We ask God—be He praised—-to bring ease to the Muslims with your arrival, to allow you to ignore what the enviers and those who spread disturbance say, and may He make your mediation good and successful. Here we are, we informed our Sovereign about how things appear to us. The bearer of this letter, Mīlād son of the hājj Sa'īd, will inform you [in more detail] verbally about what I think. Farewell.

The servant of the Porte Ġūma b. Halīfa

N.B. The translation of the passage from 'As for...' until '...the key of hearts' is purely tentative.

\section{Commentary}

1 دفترلي دار. In this Turkish term, the suffix (-lü) must initially have been written by mistake, and then left uncrossed out.

أما بعد is an equivalent of يليه 2 


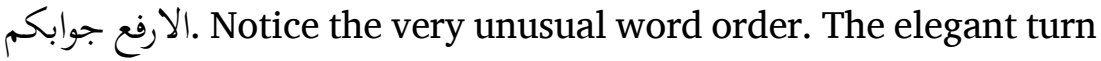
of phrase ارفع جوابكم was likely meant here.

4 قريناه. MA qara / colloquial qre (cf. Classical qara'a), a $\mathrm{C}_{3}=\mathrm{Y}$ verb.

${ }^{5}$ نريدو. Colloquial form of the $1 \mathrm{pl}$ imperfect. Notice also the 'alif al-wiqāya.

6 لاك 6. Colloquial negative turn ( $l \bar{a}+$ bound $2 \mathrm{~ms}$ pronoun) 'you are not...'. The negation is probably stronger than $m \bar{a}-k$; for Takrūna in Tunisia, see Marçais and Guîga (1958-1961, 3571).

7 تحقيق. Maf'ül muttlaq of تحققنا. This turn of phrase is not frequently used in MA. Another example is ايقودوني قود.

8 با انفسنا. Two 'alifs (| I) denoting ' $a$ (as well as $a^{\prime}$ and $\bar{a}^{\prime}$ ) is common in late MA orthography; see examples in Lentin (1997, 11112), e.g., لانهم li'annahum.

9 امحمد. The initial prosthetic 'alif indicates here that the initial syllable begins CC- (Mhammad). Cf. text II.19, no. 15.

10 انهزبت. For the meaning, compare form II hazzaba in Dozy (1881, II: 756). Corriente (1997, 549) offers another meaning: 'to dumbfound' for form $\mathrm{V}$ tahazzaba.

ال is a form of the relative (cf. the two other

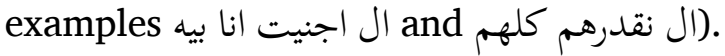

12 هاذ. Colloquial short form of the demonstrative.

ييه Colloquial (prep. bi- + bound 3ms pronoun).

14 .راجل. Colloquial rāžal 'man'.

15 ما نستحقش. Colloquial 1s imperfect and colloquial 'discontinuous' (dimorphematic) negation ma...š.

16 ايقودوني. Colloquial yqūdūni (cf. note to ln. 6 above); cf. also وايلاغِيني.

17 هاه. Colloquial deictic particle $h \bar{a}-+$ bound $3 m s$ pronoun $-h u$. 
(الخدمه ال نقدرهم كلهم. The plural agreement of the pronouns (خهم) with the feminine singular noun خدمه is rather uncommon.

19 اليا elya (and leya below). Colloquial conditional conjunction 'if'.

${ }^{20}$ اندا $n d a$ (cf. note to ln. 6 above). Cf. Classical nidā') (Boris 1958, $\left.606{ }^{\circ} \mathrm{nde}\right)$.

21 هاذا المراسله 21 هاذا noun مراسله is quite unexpected. But one should note that هاذهاسله is written here with 'alif after the $h \bar{a}$ ', whereas its other occurrences in the text read هذا. Hence one could think here of another example of I l noting 'a (see note to ln. 8 above) and read هاذ المراسله (with the short form of the demonstrative, cf. note to $\ln .12$ ). This hypothesis cannot be verified since there is no facsimile reproduction of the manuscript in the edition.

22 تتلغوا Probably , with $\dot{g}>q$, as is common in several Maghrebi Bedouin dialects. For the meaning, cf. Boris (1958, 557): lge 'ala 'to abandon, not take care of anymore, to give up, to stop talking to'.

23 gith $s>s$ (in the vicinity of $t$ ); but see above واسطة

${ }^{24}$ Colloquial هوين ha/āwēn is a kind of presentative particle. The variant هوينه occurs in another letter of Ġūma al-Mahmūīi (Wațā'iq 'an tārīh Lïbiyā... p. 244): هوينه قادم اليك 'Here he is coming to you'. Nowadays in Tripoli, hāwen- is used only with a suffixed 3rd-person pronoun (-a, -ha, -hum) or with the frozen 3ms pronoun -a: hāwēna. ${ }^{1}$

25 مشافهة = مشافاه.

${ }^{1}$ I am indebted to Christophe Pereira for this information. 



\section{T-S NS 99.38 (1809)}

\section{Geoffrey Khan and Esther-Miriam Wagner}

\section{Transcription}

$$
\begin{aligned}
& \text { 1. } \\
& \text { 2. } \\
& \text { 3. אחדש"ו נערפכם יא מחבנה באן אמס תאריכו כתבנא } \\
& \text { 4. לכם מכתוב צו' אל סאעי וערפנאכם פי בגואב } \\
& \text { 5. } \\
& \text { 6. } \\
& \text { 7. } \\
& \text { 8. } \\
& \text { 9. }
\end{aligned}
$$

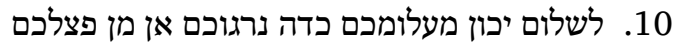

$$
\begin{aligned}
& \text { 11. חאלן תאמנונא בוצול אל מורסל לכם מן נו עגם }
\end{aligned}
$$

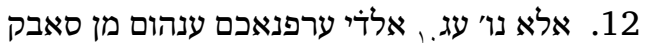

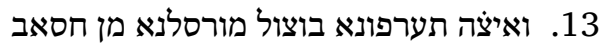

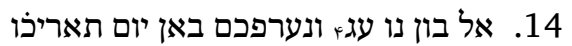

$$
\begin{aligned}
& \text { 15. ארסלנה לכם מאע סלמת תעאלא צו' רמצאן } \\
& \text { 16. שרבי תסלים אבנו אברהם אמונה נו עגוו } \\
& \text { 17. וצמנהא דכלהא תטלעו עליה ואנתום בذיר } \\
& \text { 18. בעה (?) לידכם לשלום באל וצול תערפונא }
\end{aligned}
$$

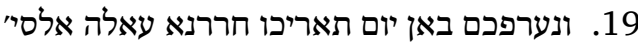

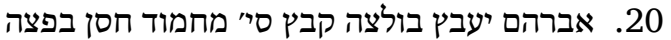

$$
\begin{aligned}
& \text { 21. ז^ץ • ו חוכם תעריפכם יכון מעלומכם ואן }
\end{aligned}
$$

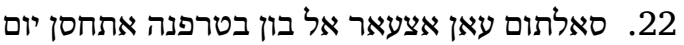

$$
\begin{aligned}
& \text { 23. }
\end{aligned}
$$

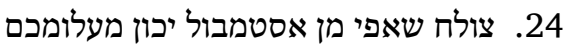


25. וסער אל בון בתאריכו עי' וג ואל פרקין באקין

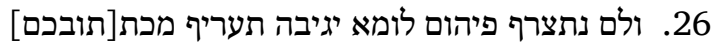

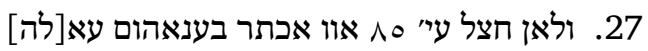

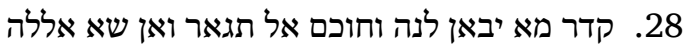

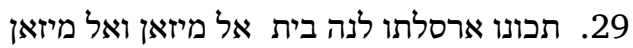

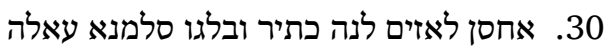

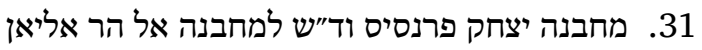

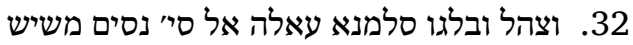

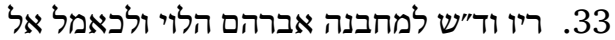

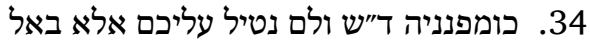
35. כיר כדמה מצלחא ערפונא נפוז בקצהא

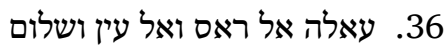

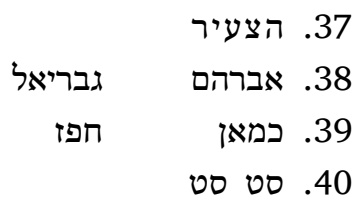

\section{Arabic Transcription}

$$
\begin{aligned}
& \text { 1. בעהש היום יום ב' זו רחמים קסטי } \\
& \text { 2. } \\
& \text { 3. مחדש"ا نعرفكم يا محبنه بان امس تاريكو كتبنا }
\end{aligned}
$$

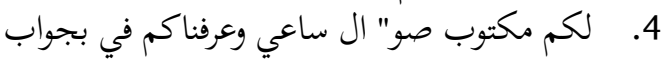

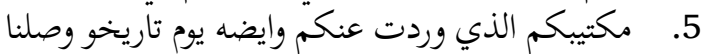

$$
\begin{aligned}
& \text { 6. مكتوب صو" بربر ال كبير ووصلنه } \\
& \text { 7. }
\end{aligned}
$$

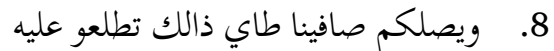

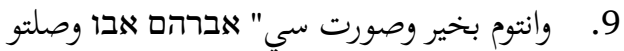

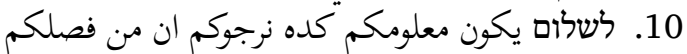

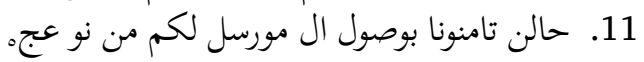

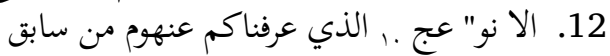

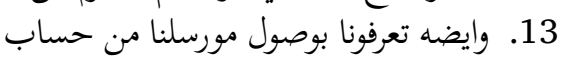

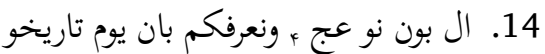

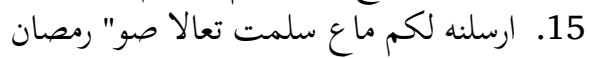




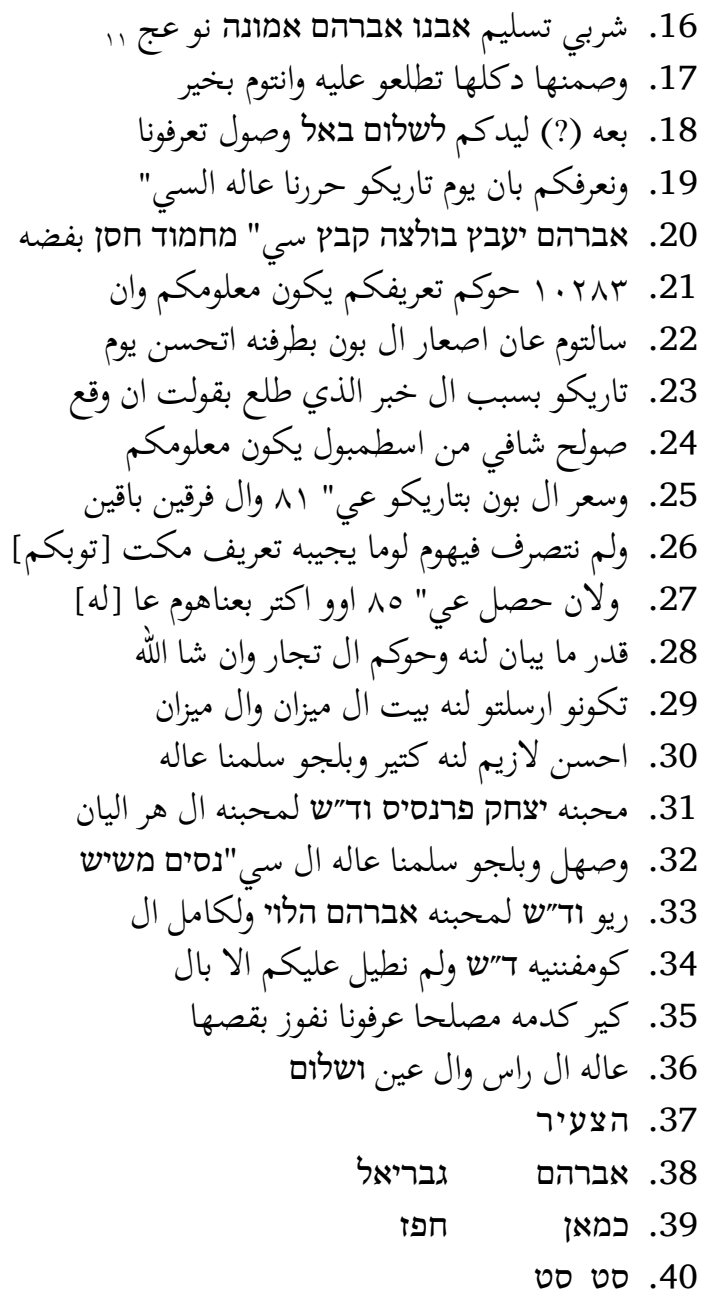

\section{Translation}

(1) With the help of God. Monday 13th of Elul (5400+) 169 (= 5569 Era of Creation $=1809 \mathrm{CE}$ ). (2) (To) our brother the master Karo Francis-may God preserve him. (3) After inquiring about your (lit. his) health, we inform you, our beloved, that yesterday we wrote (4) to you a letter via the messenger. We informed you in it about the answer (5) to your letters, which arrived from you. 
Also, today a letter (6) reached us with (the ship) Barbar the Great, it reached us (7) with the mentioned captain, (consignment) no. 15. (This) you should know. (8) Our net (profit) should reach you inside this (letter). You should understand it, (9) (and we hope) be fine with it. The purse of the lord Abraham, his father, reached him (10) safely. You should know. So we hope that you please (11) for the moment trust us with the arrival of the goods sent to you from no. 5 (12) to no. 10, which we informed you about in advance. (13) Also, inform us of the arrival of our consignment regarding (14) the coffee, no. 4 . We inform you that today (15) we sent to you under God's protection with Ramaḍān (16) Šarabī by delivery of his son Abraham, the consignment no. 11. (17) Its content is inside of it. You should understand it, (and we hope) be fine with it. (18) I sent (it) to your hand safely. When it arrives, let us know. (19) We inform you that today we made out to the master (20) Abraham Ya'bes a bill of exchange belonging to the master Mahmūè Hasan for (21) 10283 silver-dinars according to your instruction. You should know (this). If (22) you ask about the prices of coffee in our region, it is going well (23) today because of the news that arrived reporting that (24) a conciliatory settlement has been made from Istanbul. You should know (this). (25) The price of coffee is today at a value of 81 , and two portions remain. (26) We do not have authority over them until the notification of your letter brings it. (27) Because at the value of 85 or more we sold what (28) seemed suitable to us. Concerning the traders, God willing, (29) you would have sent to us the casing of the scales. We need (30) the scales very much. Convey our greetings to (31) our beloved Isaac Francis. Greetings 
to our beloved ha-rav Ilyān (32) and (to) Șahl. Convey our greetings to the master Nissim Mašiš (33) Rio. Greetings to our beloved Abraham ha-Levi and to all the (34) company greetings. We will not prolong (this letter) to you except with (35) (wishing you) the best. (If there is any) service or benefit (we could assist you with), let us know and we shall be sure to carry it out (36) with pleasure. Shalom.

(37) Ha-șa'ir

(38) Abraham

Gabriel

(39) Kamān

Hefez

(39) Simen tov/Sefardi tov Simen tov/Sefardi tov

\section{Commentary}

Line 1

Rahamim is the name for Elul, the month of prayers for forgiveness and mercy.

Line 2

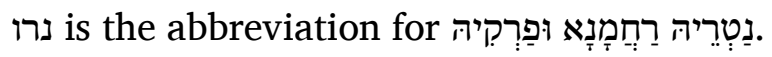

Line 3

אחרי דרישת שלומו is used for אחדש"ו The abbreviation

Line 4

In our corpus of letters, maktūb has replaced the word kitāb for צו' 'letter' used in earlier correspondence. The abbreviation stands for suhba 'with'. The form פ for fihi 'in it' shows an unusual orthography as the suffix $-h$ is not spelled.

Line 25

עי is short for 'erek 'value'. 



\section{RYLANDS GENIZAH COLLECTION A 803 (1825)}

Esther-Miriam Wagner and Mohamed Ahmed

\section{Transcription}

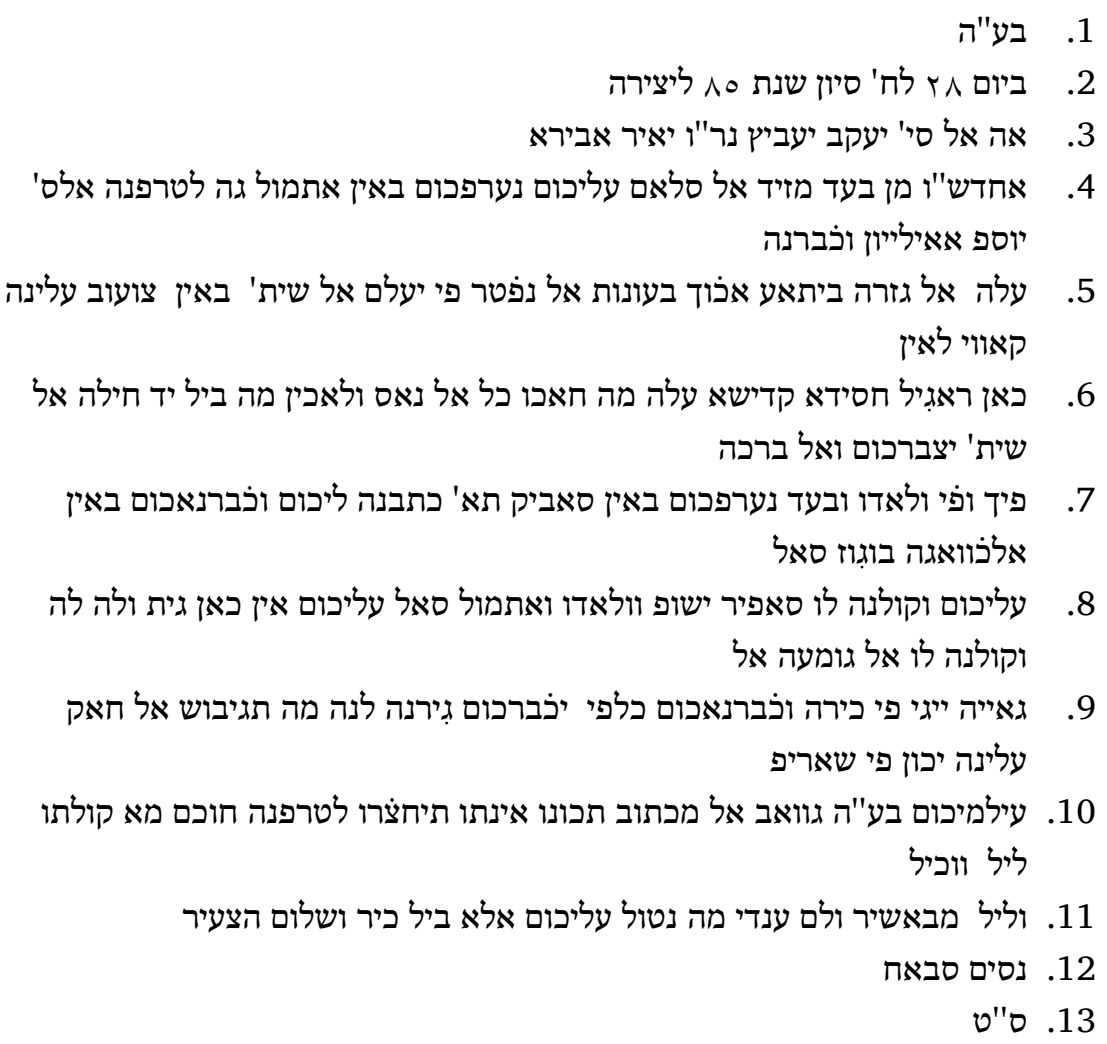




\section{Arabic Transcription}

$$
\begin{aligned}
& \text { 1 1. 1 בע"ה } \\
& \text { 2. } \\
& \text { 3. }
\end{aligned}
$$

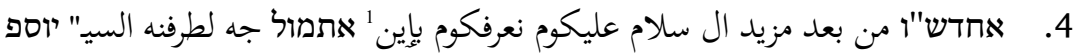

$$
\begin{aligned}
& \text { אאילייון وخبرنه } \\
& \text { 5. عله ال גזרה بيتاع اخوك בעונות ال נפטר في يعلم אל שית' بإين صوعوب علينه } \\
& \text { قاووى لإين }
\end{aligned}
$$

6. كان راجيل חסידא קדישא عله مه حكوا ال ناس ولاكين مه بيل يد حيله אל שית'

$$
\text { يصبركوم وال بركه }
$$$$
\text { 7. فيك وفي ولادو وبعد نعرفكوم بإين سابيق تا' كتبنه ليكوم وخبرناكوم بإين الخواجه }
$$

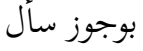$$
\text { 8. عليكوم وقولنه لو سافير يشوف وولادو و مתמاל سأل عليكوم إين كان جيت وله له }
$$

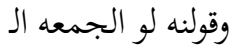$$
\text { 9. جاييه ييجي في خيره وخبرناكوم دלפי يخبركوم غيرنه لنه مه تجيبوش الحق علينه يكون }
$$$$
\text { في شاريف }
$$$$
\text { 10. عيلميكوم בע"ה جوواب ال مكتوب تكونو اينتو تيحضرو لطرفنه حكم ما قولتو ليل }
$$$$
\text { ووكيل }
$$$$
\text { 11. وليل مباشير ولم عندي مه نطول عليكوم الا بال خير وسלום הצעיר }
$$

\section{Translation}

(1) With the help of God. (2) On the 28th of Sivan of the Year 5585 of Creation (= 1825 CE). (3) (To) our beloved, the master Jacob Yabets-may God protect and preserve him-enlightened by God. (4) After inquiring about his health, and after (extending) many greetings to you, we let you know that yesterday, Mr

\footnotetext{
${ }^{1}$ In order to reflect the Hebrew spelling באין, we decided to use the ! sign here.
} 
Joseph Ayllon ${ }^{2}$ came to our area, and he informed us (5) about the punishment of your brother, dead because of (our) sins. God-may his name be blessed-knows that (this) was difficult to bear for us, because (6) he was a pious and saintly man, as all people depicted him. Yet, there is nothing we can do. May Godhis name be blessed-give you patience. It is for you ${ }^{3}$ (7) and his children to fill his place. Then we also inform you that previously we wrote to you and informed you that Mr Bogush asked (8) about you and we told him that you are travelling to see your children. Yesterday he asked about you, whether you came (back) or not. We said to him: Next (9) Friday he will come in good health. We tell you just as anyone other than us would tell you on our behalf. Do not blame it on us. You should know (10) this. ${ }^{4}$ With the help of God, (there will be an) answer to (this) letter. You should come to our area in accordance with what you told the agent (11) and the supervisor. I have nothing to add except the best of greetings. The young man (12) Nissim Sabbāh, (13) a good Sefardi.

\section{Commentary}

The code-switching between Hebrew and Arabic in this letter differs markedly from what can be observed in medieval letters. In fact, code-switching involving temporal adverbs, such as 'etmol

2 For the Ladino spelling of the name, see https://he.wikipedia.org/wiki/\%D7\%A9\%D7\%9C\%D7\%9E\%D7\%94_\%D7\%90\%D7\%90 \%D7\%99\%D7\%9C\%D7\%99\%D7\%95\%D7\%9F.

${ }^{3}$ A common Egyptian condolence, see Badawi and Hinds (1986, 68).

${ }^{4}$ Literally 'This should be to your honourable knowledge'. 
'yesterday', is not normally found in medieval Judaeo-Arabic letters, but is a much more common occurrence in Yiddish and Ladino letters. ${ }^{5}$ Medieval mercantile letters in particular avoid code-switching, ${ }^{6}$ whereas early modern traders frequently switch into Hebrew. Similarly, words such as niftar 'deceased' are not normally used in Classical Judaeo-Arabic code-switches, whereas they are commonly used loanwords in Yiddish. It could be argued that the change in style as well as frequency of mercantile codeswitching observed between medieval Judaeo-Arabic and Early Modern Judaeo Arabic, in particular in the letter at hand, was influenced by language patterns from Yiddish and Ladino through traders from Europe and Asia Minor.

Line 1

'With the help of God'.

Line 2

'לחודש = לח 'in the month'.

Line 3

אהובנו = אה 'our beloved'.

נטרה רחמנא פרקה = נר"ו 'may God protect and preserve him'.

Line 4

'After inquiring about your (lit. his) health'.

\footnotetext{
${ }^{5}$ For differences in codeswitching between Judaeo-Arabic and Yiddish, see Wagner and Kühnert (2016). A cursory analysis of all Judaeo-Arabic letters written by Daniel b. 'Azarya published in Gil (1997, 625-715) shows no temporal adverbs at all.

${ }^{6}$ See Wagner and Connolly (2017).
} 
גה Classical Judaeo-Arabic גא ג' Classical Arabic جاء 'he came'.

\section{Line 5}

צועוב 'difficult to bear'. The vocalisation here may reflect what Rosenbaum $(2002,37)$ describes as preference for $u$ over Standard dialect $i$ in Modern Jewish Egyptian Arabic, which would indicate the speaker's Jewish heritage and minority status for any listener.

Line 6

.ראגִיל The pointing of this letter and the other letters below is somewhat random. Some of those going back to Classical Arabic ج have dots beneath, as here; others do not, for example ייג' 'he will come' in line 9. Yet, also Classical Arabic \& may receive the dot, as in גִירנה 'other than us', also in line 9. The same irregularity can be found in various letters, e.g., the pointing of $\supset$ to distinguish between $[\mathrm{k}]$ and $[\mathrm{b}]$, on the one hand, and $[\mathrm{k}]$ and $[\mathrm{k}]$, on the other.

חסידא קדישא. The use of this Aramaic form again is somewhat unusual for Judaeo-Arabic letters. Yet it is commonly used in Yiddish, as mentioned by Khan $(2006,358)$.

Line 7

تاريخه = تار 'its (the letter's) time, i.e., today'.

Line 8

ולה לה. The dialectal term walla + lā' 'or not'.

וולאדו. The double spelling of ו here, as well as the double spelling of ' in 'ייג' 'he will come' in line 9, are not consistent throughout the letter and may show a preference of double spelling if $i$ is followed by short [u] if and ' is followed by [i]. 



\title{
29. SYRIA 2: CHRONICLE OF MUḤAMMAD SA'ĪD AL-'USṬUWĀNĪ \\ (1840-1861)
}

\author{
Jérôme Lentin
}

The šayh Muhạmmad Sa'īd al-'Usțuwānī (1822-1888) was a Damascene 'älim. He was hațib of the Umayyad Mosque in Damascus, and eventually held important functions in the administration of justice. In 1867, he was appointed qādì of Tripoli, and was first qāḍi šar'ī in Damascus between 1869 and 1873. His chronicle covers the years between 1840 and 1861. Edition that of 'Usṭuwānī (1993).

\section{Transcription}

p. 194

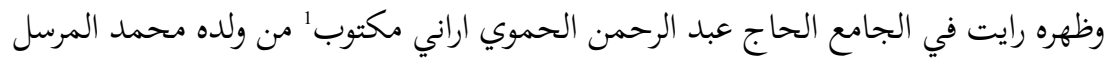

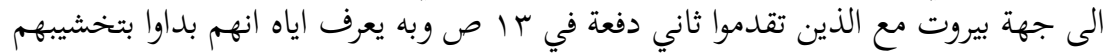

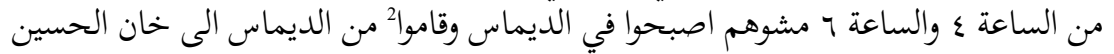

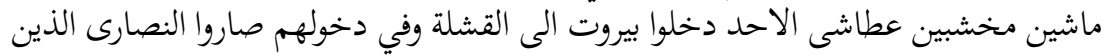

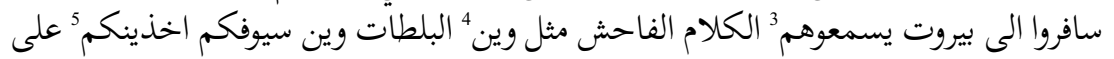

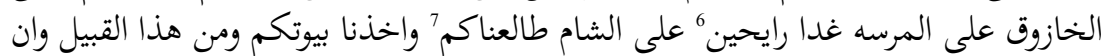

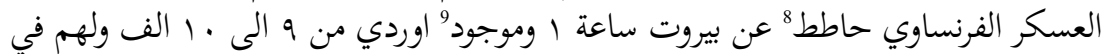

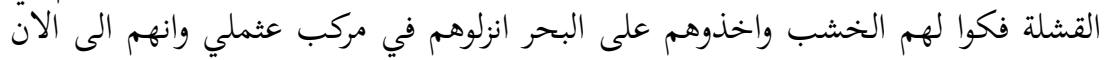

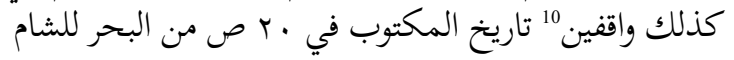




\section{Translation}

At noon of that day [Saturday, 22 Safar $1277=7$ September 1860], I saw in the mosque the hạjj 'Abd al-Raḥmān al-ḥamawī. He showed me a letter from his son Muhammad, who had been sent to Beirut with those who had preceded a second wave of people driven away on 13 Șafar. In this letter, he was informing his father that they had first been put into wooden handcuffs at 4 o'clock. At 6 o'clock they had been forced to start walking. In the morning they were in Dīmās, from where they left for Huān alHusayn, walking with their hands cuffed and thirsty. On Sunday they had entered Beirut until the barracks. When they entered, the Christians who had travelled to Beirut started addressing them with impudent words like: "Where are your axes, where are your swords? They're taking you to the stake [to impale you], to the rope [of the gibbet]! Tomorrow we are going [back] to Damascus. We have dislodged you from your houses and we have taken them!" and words of the same kind. [He was adding in his letter that] the French army had settled in Beirut at 1 o'clock, and that they had an army corps, of 9 to 10,000 [soldiers] in the barracks. And that they had unfastened their cuffs and taken them to the sea, where they had embarked them on an Ottoman boat, and that, on the date he wrote his letter, sent from the sea to Damascus on 20 Ṣafar, they were still liying at a standstill.

\section{Commentary}

1 . As a rule, 'cases' disappear in MA. Classical or classicising forms with case endings (مكتوبا) appear only in specific contexts. 
${ }^{2}$ قاموا. Colloquial use of $q \bar{a} m$.

3 يسمعوهم. For the regular $-\bar{u}$ (and not -ūn) form in MA for the 2pl and 3pl imperfect, see text II.9, n. 7.

. Colloquial interrogative adverb (wayn / wēn).

5 . Notice the temporal value of the active participle (present / immediate future).

.غدا رايحين على الشام 6. Notice the temporal value of the active participle (near future, cf. gadan).

7 'to remove, expel' (see text II.9, n. 9).

8 حاطط عن بيروت. The proposed translation follows the editor's gloss (dahala 'ilā).

9 وموجود اوردي. Mawžūd is frequently used in MA and can be analysed as a transposition of colloquial $f i$ 'there is'.

10 .واقفين. The sound masculine plural form -in is predominant (whatever the syntactic function of the noun) in MA texts, see text II.9, n. 13. 



\title{
30. ARABIA: A LETTER FROM ABDALLAH ḤIṢĀNİ TO ‘ABDALLAH BĀŠs̄Ā (1855)
}

\author{
Jérôme Lentin
}

A letter from the šayh 'Abdallah Hịșānī to 'Abdallah Bāšā, dated

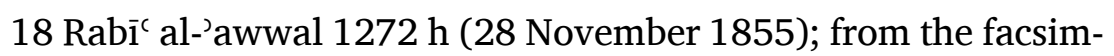
ile in 'A $\dot{g} l u ̄$ (2002, 170), since the edition (81-82) is faulty.

\section{Transcription}

$$
\begin{aligned}
& \text { تعالى }
\end{aligned}
$$

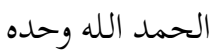

$$
\begin{aligned}
& \text { 1. الى حضرت1 قدوة الاكابر وعين الاعيان المحروس بعين الملك الديان افندينا عبد الله } \\
& \text { باشه حضه الله امين } \\
& \text { 2. السلام عليكم ورحمت الله وبركاته وبعد جانا جوابك العزيز وفهمنا مضمونه ويو³ جانا }
\end{aligned}
$$

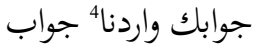

$$
\begin{aligned}
& \text { 3. سابق من امير مكه الشريف عبد المطلب ومن عند إند اهل مكه العماكّ والمفاتي ويذكرون } \\
& \text { ان النصار طبو } 6 \\
& \text { 4. مكه بيت الله الحرام وهذ العلم لا يرضاه لا الله ولا رسوله ولا الصلطان ولان من يقول }
\end{aligned}
$$

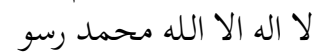

$$
\begin{aligned}
& \text { 5. ل الله وبعد بلغنا الامر هذا صابة8 المسلمين غيره دون دين محمد صلى الالى الله عليه } \\
& \text { وعلى اله وسلم ودون دينهم }
\end{aligned}
$$

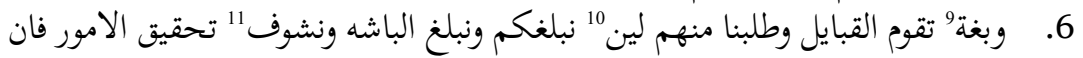

$$
\begin{aligned}
& \text { كان وكد }
\end{aligned}
$$

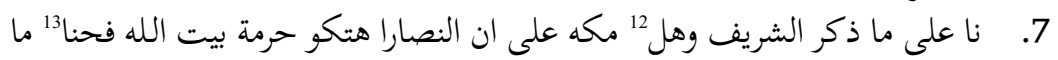

$$
\begin{aligned}
& \text { عندنا طاعه }{ }^{14} \text { لنصار و الثر لا لمن وهل }
\end{aligned}
$$




$$
\begin{aligned}
& \text { 8. يعينها وقايمين } 15 \text { عليها غيرت فدين } 16 \text { ومستعينين بلا لله وبرسوله وبكلمه التوحيد كما }
\end{aligned}
$$

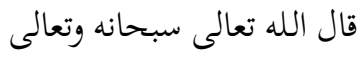

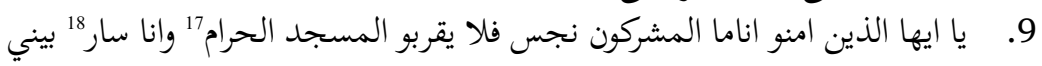

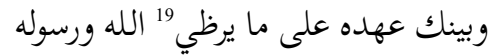

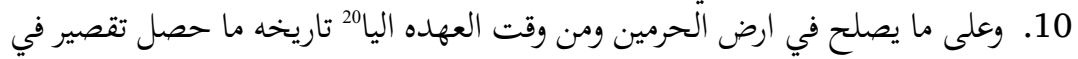

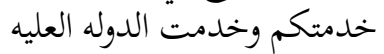

$$
\begin{aligned}
& \text { 11. وحنا خدامه بلا مصلحه معك ومع الدوله العليه كله في شان الدمله محبة افندينا ومحبتك } \\
& \text { السبب انك } \\
& \text { 12. راع صدق222 معي وحنا عرفنا سعادت افندينا بجواب ونرقب23 جوابه ونرقب جواب منك } \\
& \text { وحنا مجتهلين }
\end{aligned}
$$

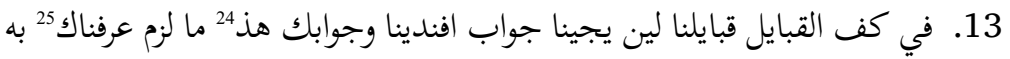

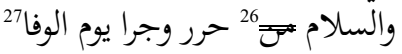

$$
\begin{aligned}
& \text { 14. من ربيع اول سنة rVI I المر من خادمك الشيخ عبد الله حصاني [ختم] }
\end{aligned}
$$

\section{Translation}

Praise be to God alone, exalted be $\mathrm{He}$

(1) To his Lordship, model of the grandees and prominent among the leaders, protected by the eye of the Retributing Sovereign, our Sir ('Afandinnā) 'Abdallah Bāšā-may God prompt him [to godly works]. Amen. (2) Greetings to you and the mercy of God and His blessings be upon you. - I have received your esteemed letter and I have perfectly understood the contents. The [very] day it arrived, we had [just] received a letter (3) from the 'amir of Mecca the Sharif 'Abd al-Mutțalib and from the people of Mecca, 'ulam $\bar{a}$ ', and muftis. They were reporting that the Christians entered (4) Mecca, the Sacred House of God. Such news satisfies neither God, nor His Prophet, nor the Sultan, nor those who say that there is no deity except God and that Muhammad is His (5) messenger. When we heard that, the Muslims felt full of ardour [to fight] for the religion of Muhammad (God bless him and 
grant him salvation) and for their religion. (6) The tribes wanted to rise up. We asked them [to wait] until we inform you and the Pasha and until things are confirmed. If it proves true (7) that the Christians disgraced the sanctity of the House of God, as the Sharif and the people of Mecca said, we will yield neither to the Christians nor to those who (8) support them and we will rise against them in zeal for the religion and we will seek the help of God, of His Prophet, and of the proclamation of His unicity. As God— praised and exalted be He—said: (9) "O you who believe! The Associationists are nothing but impure, so let them not approach the Inviolable Mosque." You and I have concluded a pact [making a commitment] to do what satisfies God and His Prophet (10) and what is right in the land of the two sanctuaries. From the day we made this pact until today, I have never failed to serve you and the Sublime Porte. (11) We serve without taking any advantage from you or from the Sublime Porte, doing all this [only] for the sake of my love for our Sire and for you. This is because you are (12) truthful with me. I have informed His Grace, our Sir, in a letter and I am waiting for his answer. I am waiting as well for an answer from you. I am doing my best (13) to hold back the tribes until I receive the answer of our Sir and yours. This is what I needed to tell you. Greetings. This was written the day of alwafā(') (14) of Rabī' al-'awwal 1272 by your servant the šayh 'Abdallah Ḥiṣānī [seal] 


\section{Commentary}

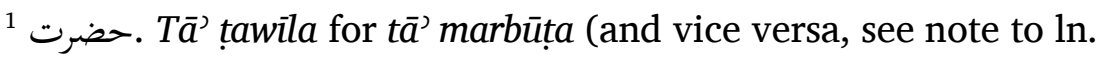
7) is common in MA texts. Cf. ln. رغمت 2 رحمت 8 , إت 8 سعادت 12.

${ }^{2}$ ج žă 'to come' is common in MA (see text 'Syria 1', note to ln. 19). Cf. the imperfect يجين in ln. 13.

يو is most probably an apocopated form of 'when'.

${ }^{4}$ واردنا. Notice the perfective aspectual value of the active participle.

${ }^{5}$ العما is probably to be read المفاتي .العلما is either an unusual plural of muftin (Classical muftūn), or-less likely—the plural of مفنى 'counsel' (see Piamenta 1990-1991, II:366).

tabb 'to enter' (colloquial). The spelling without 'alif alwiqāya is consistent in this text (as in others) for the perfect (امنو (ln. 7) and 9) and the imperfect (ln. 9).

7 al-ṣultān ( > al-sulțān).

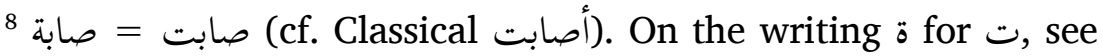
note to $\ln .1$.

9 بغة تقوم القبايل. The (colloquial) modal auxiliary (3fs) bagat (on the writing a for ت, see note to $\ln$. 1) is constructed asyndetically, as is generally the case in MA texts.

10 لين. Colloquial lèn 'until' (for a further example see note to ln. 13).

11 نشوف. This colloquial verb (šăf 'to see') appears frequently in MA texts, even in the less colloquialising ones.

أهل مكه = هل مككه 12.

${ }^{13}$ حن hinna. Colloquial personal pronoun (for further examples see notes to lns 11 and 12 [2x]). 
لا ما عندنا طاعه 14 (طاعة لنا

15 For the frozen sound masculine plural form in -in see text II.9, n. 13 and text 'Syria 2', n. 10. Further examples of the same in thisln. 8 and $\ln .12$

16

في الدين = فين

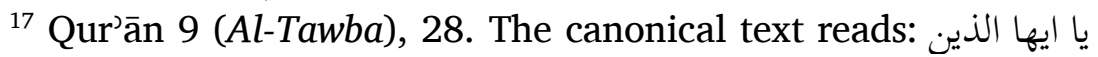

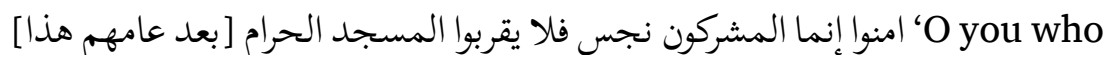
believe! The Associationists are nothing but impure, so let them not approach the Inviolable Mosque [after this year of theirs]'. 18 صار = 18.

19 يرضي = يرظي

الى Colloquial ilya, cf. Classical.

Colloquial prepositional phrase fi šān 'for, for the sake of'.

22 إع 'owner', hence 'provided with' (colloquial = Classical ذو صاحب); cf. de Landberg (1920-1942, II:1321).

23 ragab 'to wait for' (colloquial).

24 هذ. Short form of the colloquial demonstrative hāda.

25 ما لزم عرفناك. Notice the asyndetic construction of لزم 25 , and the perfect form of the auxiliary verb.

26 is crossed out in the manuscript.

27 . 77th (or 78th) day of the lunar year, 18 Rabī' al-'awwal. 



\title{
31. EXCERPTS FROM YA'QŪB ȘANŪ'S ABŪ NAḌ̣̂̄RA ZAR'A AND 'ABD ALLĀH AL-NADĪM'S AL-USTĀD
}

\author{
Liesbeth Zack
}

This chapter presents excerpts from two of the most famous 19thcentury Egyptian newspapers: Abu naddāara zar'a 'The man with the blue eyeglasses', founded by Ya'qūb Sanū' in 1878, and alUstād 'The professor', founded in 1892 by 'Abd Allāh al-Nadīm. Both were satirical newspapers, critical of Egyptian society and of the regime, and both were (partially) written in Egyptian Arabic, which could be read aloud in order to make them accessible to the uneducated masses. This makes them interesting subjects for a comparative linguistic study.

\section{Ya'qūb Șan $\overline{\mathbf{u}}^{\mathrm{c}}$}

The Jewish Egyptian journalist and playwright Ya'qūb Șanūc, also known as James Sanua, was born in Cairo in 1839. His father Rafā'îl was a Jewish merchant who moved from Livorno in Italy to Cairo at some point in the 19th century, while his mother,

${ }^{1}$ This is an abridged version of section 2 in Zack (2014). See also http://kjc-sv036.kjc.uni-heidelberg.de:8080/exist/apps/naddara/biography.html for a short introduction to Șanū's life and works. 
Sara, was a Cairene by birth. Rafā'îl Șan $\bar{u}^{\complement}$ worked as an adviser to Ahmad Pasha Yagan, the nephew of Muhammad 'Alī Pasha. ${ }^{2}$ Aḥmad Pasha Yagan sponsored Ya'qūb during the course of a three-year period of academic formation in Livorno, where he studied political economy, international law, the natural sciences, and the fine arts. Upon his return to Cairo, Sanū' began work as a teacher. ${ }^{3}$ He became a follower of the great thinker Jamāl al-Dīn al-Afğānī, who encouraged him to apply his literary skills to the cause of reform and suggested using the theatre as an instrument of public education. The Khedive Ismācill had opened two theatres in Cairo and Alexandria in 1869, on the occasion of celebrations in honour of the completion of the Suez Canal. Șanū' translated some European plays into Arabic, but also wrote others in both colloquial and Classical Arabic, setting them in Egyptian society. He was an important figure in the birth of Egyptian drama, and became known as the 'Molière of Egypt'. However, since his plays contained satirical portrayals of Egyptian society and criticism of government officials, Ismācīl withdrew his support and banned his plays in 1872, ending his career as a dramatist. ${ }^{4}$

\footnotetext{
${ }^{2}$ See Gendzier (1966, 17).

${ }^{3}$ Gendzier (1966, 6-17, 19).

${ }^{4}$ Gendzier (1966, 29-38).
} 
In 1878, Sanū' published the first issue of his satirical newspaper $A b u$ naḍ̂āra zar'a 'The man with the blue eyeglasses', ${ }^{5}$ which was his own nickname. The publication was written in large part in colloquial Egyptian Arabic and contained imaginary dialogues and letters, sketches, fictitious minutes from meetings and dreams. In 1878, Șanū' was banned from Egypt because of his criticism of the regime. He consequently settled in Paris, but continued to publish the newspaper. ${ }^{6}$ The final issue appeared in December 1910. Sanū $\bar{u}^{c}$ remained in France for the rest of his life, even when changed political circumstances would have allowed him to return to Egypt. He died in Paris in 1912.

The excerpt presented here is from the fifth issue of $A b u$ Naḍ̣̂āra and discusses how Ya'qūb Șanū' collected the materials for his newspaper. It is a fictional dialogue between Abu Naḍḍara and Abu Khalil. The dialogue is a stylistic device often used by Șanū', as well as by the journalist 'Abd Allāh al-Nadīm (1843-

${ }^{5}$ The first issue can be found here: http://kjc-sv036.kjc.uni-heidelberg.de:8080/exist/apps/naddara/journals.html?collec-

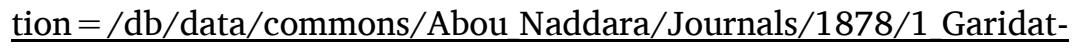
Abi-Naddara-Zarka_issues-001-015. It was published on $21 \mathrm{Rabī}^{`} \mathrm{al}$-awwal [12]95 AH, which corresponds to 25 March 1878.

${ }^{6}$ Due to censorship, he had to change the name of the newspaper regularly. There are issues entitled Al-nadḍārāt al-mișriyya 'the Egyptian spectacles', Abu șuffāra 'the man with the whistle', and Abu zummāra 'the man with the oboe', among others.

${ }^{7}$ See also this webpage published by Heidelberg University for more information on Abu naḍāara and the other journals that Șanū' published in Paris: http://kjc-sv036.kjc.uni-heidelberg.de:8080/exist/apps/naddara/intro journals.html. Scans of all the journals are available on this website as well. 
1896) fifteen years later in his magazine al-Ustād, as the next section demonstrates.

\section{'Abd Allāh al-Nadìm}

The Egyptian reformist 'Abd Allāh b. Miṣbāḥ al-Ḥasanī, known as al-Nadìm 'the boon companion', was born in 1843 in Alexandria, where he studied at the mosque of Ibrāhīm Pasha. After completing his education, he worked for some time as a telegraph officer in the Delta and as an udabāti, an itinerant versifier. ${ }^{8}$ Later he owned a lingerie shop, in order to earn a living beside his work as a journalist. The shop doubled as a literary salon, where poets and writers met. ${ }^{9}$ In 1879 , al-Nadìm joined the secret society Jam'iyyat Miṣr al-Fatāt/Union de la Jeunesse Egyptienne, but soon left it to establish al-Jam'iyya al-Khayriyya al-Islāmiyya 'the Islamic Charitable Society'. In 1881, he first founded the satirical magazine al-Tankit wa-l-Tabkit 'Joking and reproaching' and then al-Ṭa'if 'The wanderer'. The latter became the organ of the followers of 'Urābī Pasha, an Egyptian army colonel who aimed at ending the British occupation of Egypt. After the failure of the 'Urābī revolt in 1882, al-Nadīm spent years in hiding and was finally arrested in 1891, exiled, and subsequently pardoned in 1892. Upon his return to Egypt, he founded the satirical newspaper al-Ustād 'The professor', which ran from August 1892 until

\footnotetext{
${ }^{8}$ See Sadgrove (2012).

${ }^{9}$ It was not uncommon in that era for shops to double as literary salons; see Doss $(1998,144)$.
} 
June 1893. He was then once again exiled and spent the rest of his life in Istanbul, where he died in $1896 .{ }^{10}$

Al-Ustā $\underline{d}$ is a weekly satirical newspaper in which criticism of the Egyptian regime, the British occupation of Egypt, and various social issues are addressed, often in the form of dialogues. The first excerpt from al-Ustād that is presented here is part of a series of dialogues entitled Madrasat al-banāt 'the girls' school'. The dialogue is between Zakiyya and Nafīsa. Nafisa attends the girl's school and Zakiyya asks her about the subjects she is learning, questioning the usefulness of subjects such as French and English. The second excerpt is also a dialogue between two women, Latịfa and Dimyāna. The text shows the problems caused by drinking alcohol. This fragment is interesting from a linguistic point of view, because * $q$ is consistently written with a hamza, imitating the way it is pronounced in Cairene Arabic.

\section{Transcription: Abu naḍ̣̄āra zar’a}

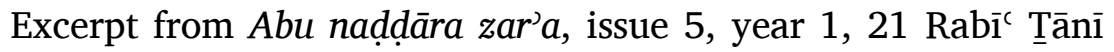
$1295,{ }^{11} 1$

(أبو خليل) أنت عبارتك ايه يابو نظاره - بقى ما عندكش لا شغله ولا مشغله الا كتابة

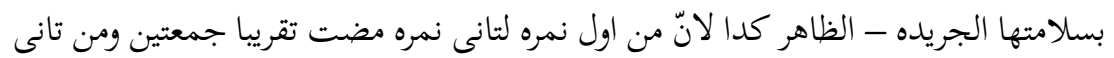

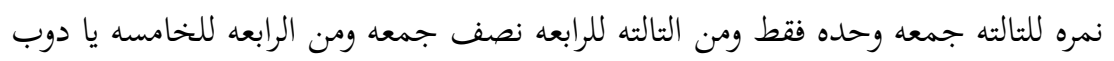

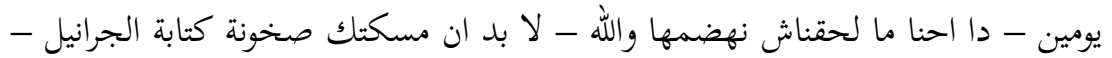

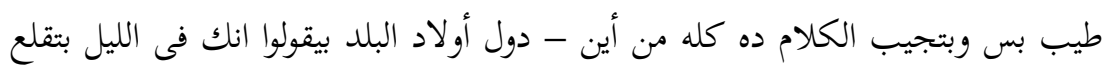

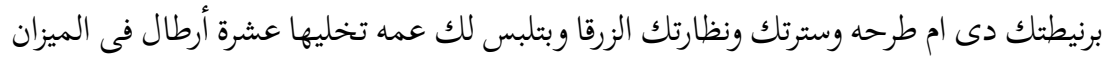

\footnotetext{
${ }^{10}$ See Sadgrove (2012).

$11=24$ April 1878 .
} 
وجبه فروزى وافطان شاهى وحزام طرابلسى وصرمه حمرا وخزرانة أولاد الفن فى يدك وبتلزق

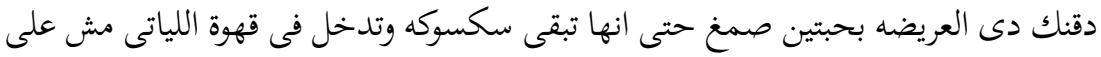

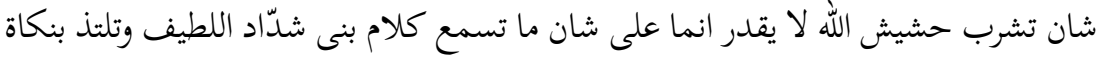

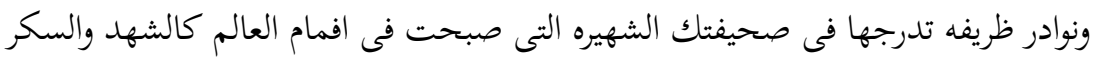

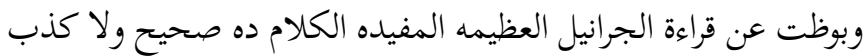

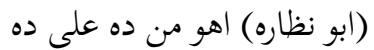

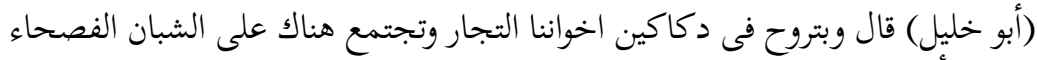

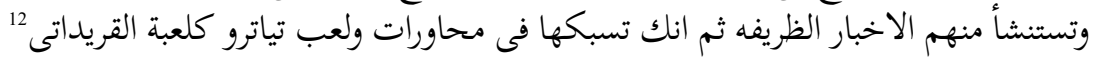
التى حصلت في أيام الغز وما أشبه ألنه (أبو نظاره) أى نعم في أئم

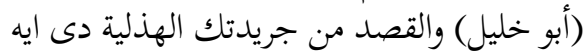

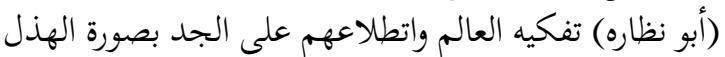

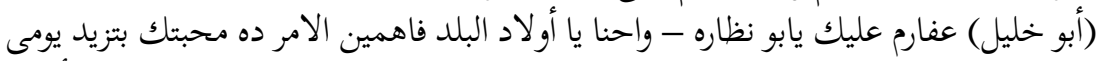

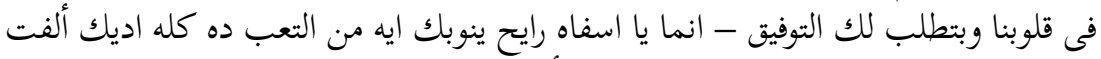

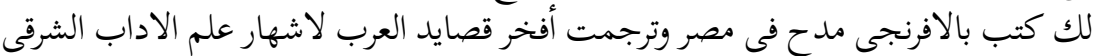

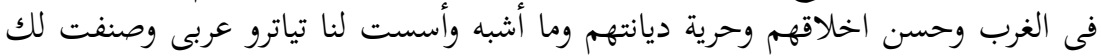

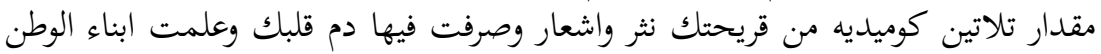

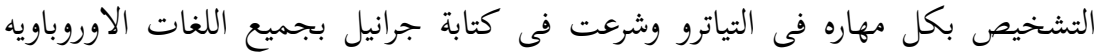

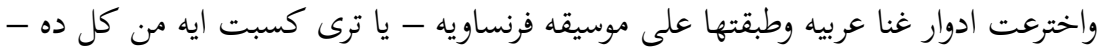
بس ربيت لك أعداء وضديات [...

\section{Translation}

(Abu Khalīl) What's the matter with you, Abu Naḍḍāra? You haven't got anything to do now other than writing this fine ${ }^{13}$ news-

12 This is a typo. It was actually called القرداتي al-quradāti. It was pub-

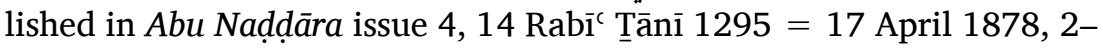
4.

${ }^{13}$ Literally 'with her well-being'. See Spiro (1895, 288): “بلامته الخواجه 1 2 this fine gentleman, this good fellow." 
paper, or so it seems, because between the first issue and the second approximately two weeks passed, and only one week between the second and the third, and half a week between the third and the fourth, and hardly two days between the fourth and the fifth. By God, we haven't had time to digest it, surely newspaper writing fever has taken hold of you. All right, so where do you get all this talk from? The guys in town say that in the evening you take off this hat of yours with its veil and your coat and your blue eyeglasses, and put on a turban that weighs ten pounds on the scale, and a turquoise robe, a striped caftan, a belt from Tripoli, ${ }^{14}$ and red shoes, with an artist's bamboo cane in your hand, and you glue that wide beard of yours with two bits of gum so it becomes a goatee. Then you go into the Layyāt $i^{15}$ coffee shop, not to smoke hash, may God forbid, but to listen to the amusing words of the hashish-smokers ${ }^{16}$ and to enjoy the jokes and the funny anecdotes that you put in your famous newspaper, which has become like honey and sugar in everyone's mouths and has detracted people from reading the great, useful newspapers. Is that right or is it a lie?

(Abu Naḍḍāra) A bit of this and a bit of that.

14 “ tharablus silk sash of Syrian make” (Spiro 1895, 362).

${ }^{15}$ This is probably the name of the coffee shop or its owner. The layy, pl. layyāt, is the flexible tube of the water pipe (šišsa), and layyāti is the nisba-adjective referring to this: 'the one with the water pipe tubes'.

${ }^{16}$ See Badawi and Hinds (1986, 456b). The $f a^{` c} \overline{a l}$-form is an intensive noun, so بنى شدّاد means 'those who take pulls [from the water pipe] often'. 
(Abu Khalil) It is said that you go to the shops of our colleagues the traders and meet up there with the eloquent young men looking for funny news stories, which you then transform into dialogues and theatre plays like the play about the monkey keeper, which took place in the days of the Mameluks, ${ }^{17}$ and the like.

(Abu Naḍḍāra) That's correct.

(Abu Khalīl) And what is the purpose of this humorous newspaper of yours?

(Abu Naḍḍāra) Amusing people, and presenting serious information in the form of humour.

(Abu Khalīl) Well done, Abu Naḍḍāra! We, the people of this country, understand this matter. Our love for you is growing daily in our hearts, and we wish you all the best of luck. But oh grief, what is all this trouble going to get you? You've ${ }^{18}$ written books in European languages praising Egypt, you have translated the most wonderful poems of the Arabs in order to spread the word in the West about Oriental literature, their good manners, their freedom of religion, and the like, and you've founded an Arab theatre for us and have written around thirty comedies using your great talent, prose and poems, and have paid a very high price for it, ${ }^{19}$ and you have taught the people of our country to perform skilfully in the theatre, and you have started writing

${ }^{17}$ The full title: القرداتى - العبه تياتريه تاريخية حصلت فى أيام الغز سنة The 1204 'The monkey keeper-A historical theatre play taking place in the days of the Mameluks in the year 1204'. The year corresponds to 1789-1790 CE.

${ }^{18}$ Lit. 'there you are'.

${ }^{19}$ Lit. 'you have spent the blood of your heart'. 
newspapers in all European languages and have created Arabic songs and set them to French music - so I wonder what you have gained from all of this? You have only made ${ }^{20}$ enemies and hostilities. [...]

\section{Transcription: Al-Ustād}

Excerpt 1: al-Ustā $\underline{d}$ year 1, no. 11, 1 November 1892, 246

مدرسة البنات زاكيه ونفيسه

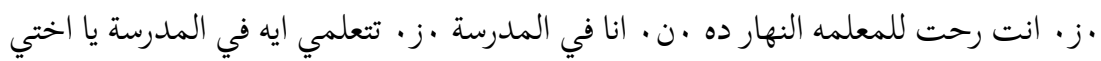

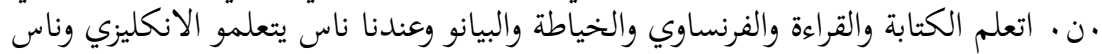

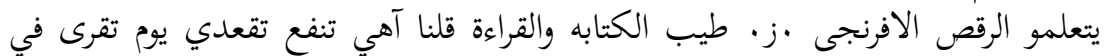

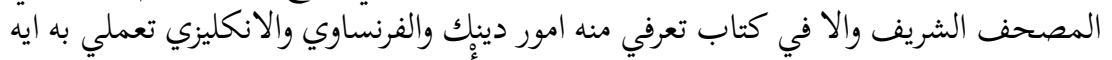

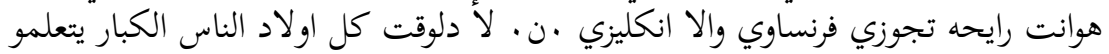

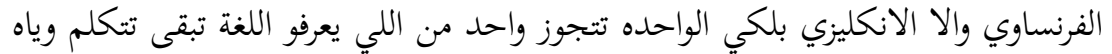

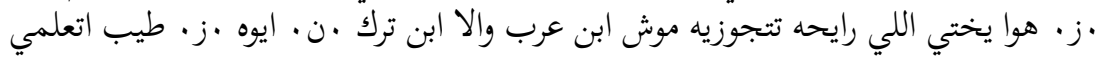

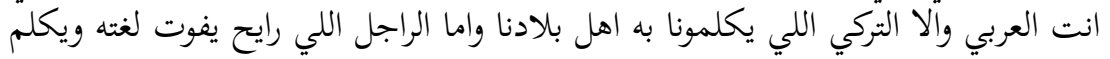

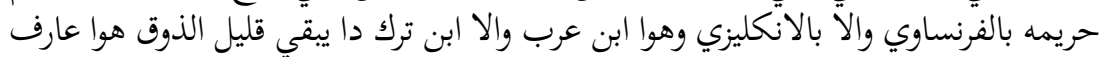

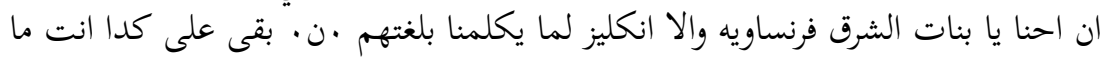

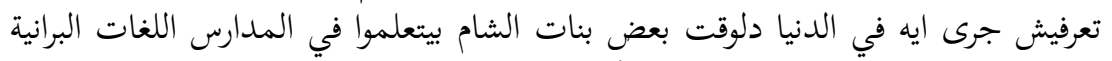

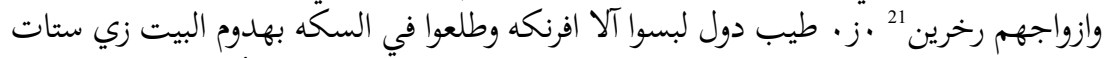

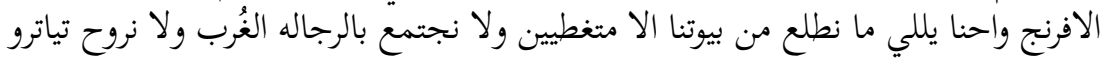

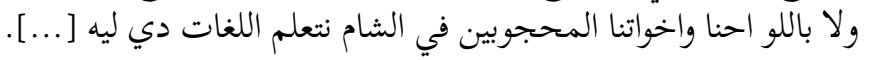

\section{Translation}

The Girls' School

Zakiyya and Nafīsa

${ }^{20}$ Lit. 'raised'.

${ }^{21}$ From الآخرين, with $l>r$. 
Z: Did you go to the teacher today? N: I attend school. Z: What are you learning in school, dear? ${ }^{22} \mathrm{~N}$ : I'm learning writing, reading, French, sewing and piano, and we have people who are learning English, and people who are learning European dancing. Z: Well, writing and reading, we'd say that, yes, they are useful so one day you can sit and read the Holy Qu'rān, or a book from which you learn things about your religion, but French and English, what are you going to do with those, are you going to marry a Frenchman or an Englishman? N: No, all the upper-class children learn French or English now. A woman may marry one of those men who know the language, so she can talk with him. Z: My dear, isn't the man whom you're going to marry a descendant of an Arab or a Turk? N: Yes. Z: Well, then learn the Arabic or Turkish language used by the people of our country when they talk to us. As for the descendant of an Arab or a Turk who puts his language aside and addresses his wife in French or English, he has no manners. He knows that we, girls from the East, are neither Frenchmen nor Englishmen, when he talks to us in their language. N: That means you're not aware of what's going in the world these days. Some girls from the Levant learn foreign languages at school and so do their husbands. Z: All right, those girls are dressed 'à la European' and have taken to the streets in house clothes like European ladies, but we, who only leave the house covered up, don't get together with strange men and don't go to the theatre or the ball, why should we and our veiled sisters in the Levant learn these languages [...].

${ }^{22}$ Lit. 'my sister'. 


\section{Transcription: Al-Ustād}

Excerpt 2: al-Ustā $\underline{d}$ year 1, no. 7, 4 October 1892, 149-50

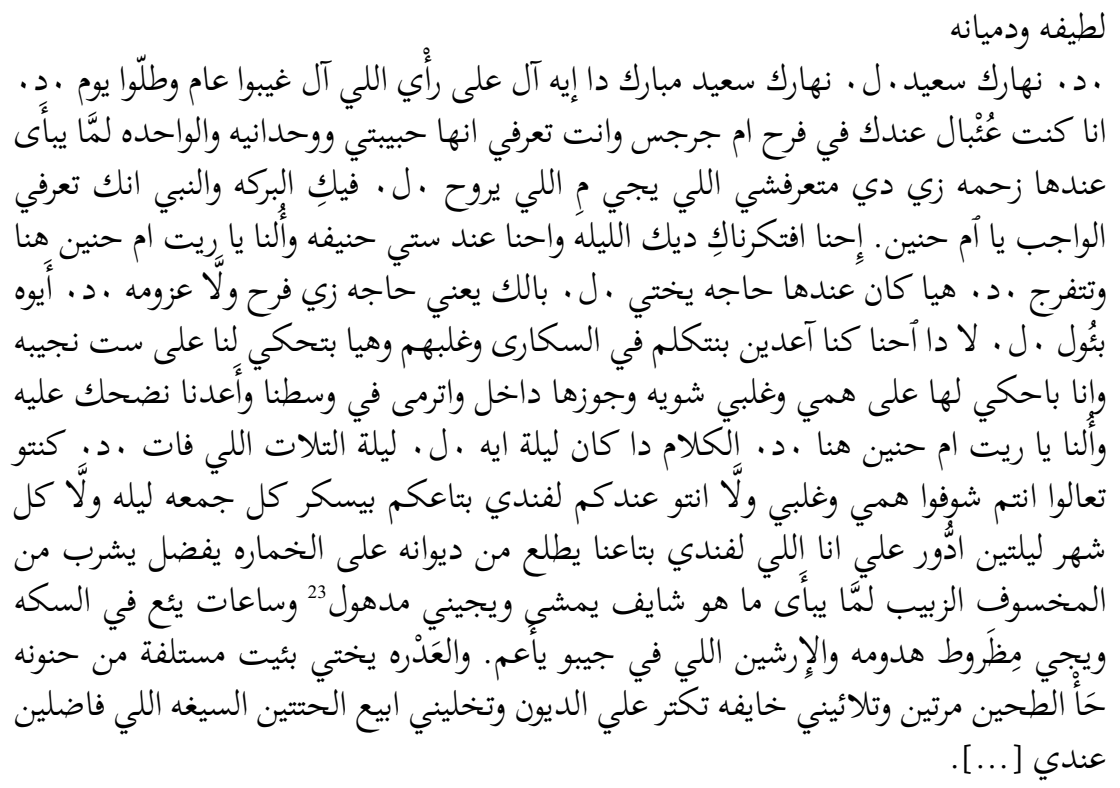

\section{Translation}

Lațîfa and Dimyāna

D: Good day. L: Good day to you. What is this? Like the famous saying, you disappear for a year and then you show up for one day. D: I was at the wedding of Umm Girgis, ${ }^{24}$ may your children follow, and you know that she's my dear friend and that she's lonely, so when someone has a crowd like that, you don't know

\footnotetext{
${ }^{23}$ Read midahwil, not madhūl.

${ }^{24}$ Lit. 'the mother of Girgis', the kunya: calling a man or woman by the name of their eldest son.
} 
who's doing what. ${ }^{25} \mathrm{~L}$ : God bless you, by the Prophet, you are always ready to help, ${ }^{26} \mathrm{Umm}$ Hinēn. We remembered you the other night when we were at Mrs. Hanïfa's and we said, we wish Umm Hinēn were here to watch this. D: Did she have something going on, sister? L: Do you have something specific in mind like a wedding or an invitation? D: Yes, that's what I'm saying. L: No, we were sitting and talking about drunkards and the nuisance they cause, and she was telling us about Mrs. Nagiba and I was telling her a bit about my worries and misery, when her husband came in and fell among us and we sat laughing at him and said, we wish Umm Hinēn were here. D: What night did that happen? L: Last Tuesday night. D: You should have come and seen my worries and misery, your man is getting drunk one night a week or two nights a month, now it's my turn, our man leaves his office and goes straight to the bar and he keeps on drinking that damned ${ }^{27}$ arrack $^{28}$ until he can't see where he's walking and comes to me a wreck, and sometimes he falls in the street and comes home with his clothes soiled and the few piastres ${ }^{29}$ that were in his pocket have fallen out. By the Virgin, my sister, I have borrowed the money for the flour from Hannūna ${ }^{30}$ twice and I'm

\footnotetext{
${ }^{25}$ Lit. 'you don't know the one who's coming from the one who's going'. ${ }^{26}$ Lit. 'know your duty'.

27 Lit. 'sunken into the ground', see Spiro (1895, 171a) ولد مخسوف 'a damned boy, a young rascal'.

${ }^{28}$ A liquor made from raisins, see Spiro $(1895,246 a)$ " عرقي زبيب native whiskey made of raisins."

${ }^{29}$ Lit. 'the two piastres'.

${ }^{30}$ Diminutive of endearment of her son's name Hinēn.
} 
afraid $^{31}$ that I will get more into debt and will have to sell the few bits $^{32}$ of jewellery I still have [...].

\section{Commentary}

\section{Orthography ${ }^{33}$}

(Ṣ = Șanū' ${ }^{\prime}, N 1$ = Nadīm, first excerpt, N2= Nadìm, second excerpt)

*) has mostly disappeared in medial and final position, e.g., حمرا

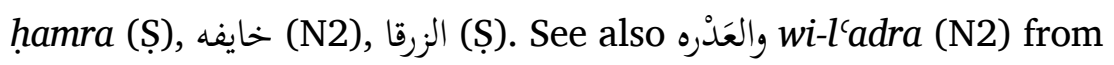
, in which the hamza has disappeared and the $\bar{a}$ has shortالقراءة ened to $a$. There are, however, some exceptions, such as (N1), أُّي (S) الفصحاء (N2).

*q: Pronounced as a glottal stop in Cairene Arabic, except in loans from Classical Arabic. In Ṣ and N1, mostly written with $q \bar{a} f$, e.g., قليل الذوق 'alil izzō' (N1), بتلزق دقنك bitza' da'nak (S), except for افطان 'ufțān (Ș). In N2, *q is consistently written with hamza, e.g.,

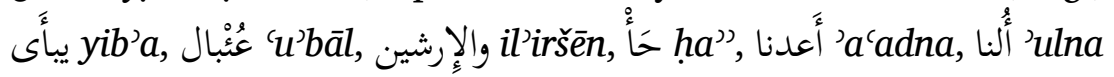
(compare قلنا in N1), بئول $b a^{3} \bar{u} l$. The Classical Arabic rules for writing the hamza are not followed here. For instance, in عُبْبَ ' $u$ 'bāl the hamza should have the $w \bar{a} w$ as its seat rather than the $y \bar{a}^{\prime}$ because of the $u$-vowel. The same applies to بئُو $b a^{3} \bar{u} l$. When a word starts with a glottal stop $(<* q)$ followed by a long $\bar{a}$, this

\footnotetext{
${ }^{31}$ Lit. 'you find me afraid'.

${ }^{32}$ Lit. 'the two pieces'. The dual is often used to indicate 'some, a few', just like English 'a couple of'. See Woidich $(2006,114)$.

${ }^{33}$ See also Avallone (2016, 81-82), who analysed the orthography in a sample of 22 pages from Abu naḍ̂āra and 21 pages from al-Ustād.
} 
is written with $\bar{T}$, as in ${ }^{\top}$ ' $\bar{a}$ l, even if this long $\bar{a}$ is shortened in the pronunciation, as in آعدين 'acdin.

$y \bar{a}$ ' and 'alif maqșūra bi-šakl al-yā' are interchangeable in N1, e.g.,

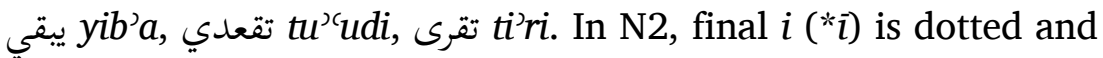

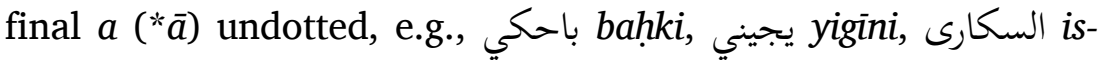
sakāra, اترمى itrama. In Ṣ, both final yō' and 'alif maqșūra bi-šakl al-y $\bar{a} \bar{a}^{\prime}$ are consistently written without dots, e.g., طرابلسى țarabulsi.

The 3ms possessive suffix $-u$ can be written with $w a \bar{w} w$, e.g., جيبو gēbu (N2).

Plene writing of short vowels occurs in موش muš and هوا huwwa (N1) and in هiyya (N2). In the verb, the final 2fs vowel -i is written plene, e.g., تتعلمي tit'allimi (N1) and تعرفي ti'rafi (N2). However, in N1 inti is written without the final vowel -i, which is indicated with a kasra in N2: وانتِ. Also, the final vowel of $-k i$ is indicated with a kasra: فتكرناكِ iftakarnāki (N2), rather than with the letter $y \bar{a}^{\prime}$.

Elision of letters: min is abbreviated to mi- in N2: من اللي for م اللي. In N2, ya-xti is written as يختي, while N1 writes both يا اختي :لتي مي and .يختي

In N1, both walla 'or' and wala 'nor' (the second part of the negation 'neither... nor') are written as g. walla: في المصحف الشريف زوالا في كتاب wala: موش ابن عرب والا ابن ترك. In N2, walla is written as لا

$t \bar{a}^{3}$ marbūta is randomly written with or without dots in N1 and N2: المدرسة ilmadrasa (N1), رايحه rayha (N1), and consistently without dots in Ș (except in genitive constructions), e.g., شغله 
šugila, سكسوكه saksūka. In genitive construction, the dots are always written in the three texts: مدرسة البنات madrast ilbanāt (N1), lelt ittalāt (N2), يلة التلات حرية دياتنهات بhurriyyit diyanithum (Ṣ). In بنكاة bi-nikāt (Ș), tā̄ marbūta is written instead of $t \bar{a}$.

'alif fāsila is sometimes written and sometimes left out: يتعلمو (N) بيتعلموا (N1), كنتو تعالوا (N2).

The $l$ of the article is once assimilated to the next 'sun' letter: ادُّور iddōr (*ildōr) (N2). In لفندي lafandi, the $i$ of the article il-is elided, as is the 'alif of the word افندي (N2).

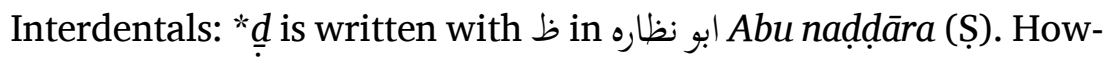
ever, it is written with ض in the very first issue of the newspaper. The $\underline{d} a \bar{l}$ in الهذلي (S) is a hypercorrection; the root in Classical Arabic is HZL. Șanūc tends to write *d with ذ̇, e.g., كذبه $k i z b \sim k i d b$.

Emphasis: صخونة is written with صinstead of س in Ș.

Shortened long vowels are generally written with long vowels,

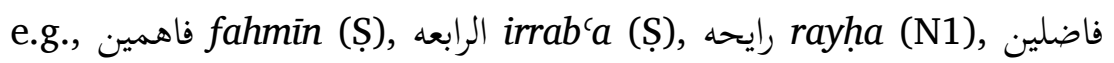
fadlin (N2). An exception is وحده wahda (S).

In S, historical spelling is used more often than in $\mathrm{N} 1$ and $\mathrm{N} 2$, for instance: minēn, نصف misf nușs. It is unclear in the second case if the Classical or dialectal pronunciation is intended, because Șanū' tends to use some Classical Arabic vocabulary. 
(S), the mașdar of form eight of the root T.L' (اطظّلاعهمم) is an odd spelling and could be a typo, perhaps influenced by تطلّع of form five.

\section{Morphology}

The demonstrative ده is not fixed to the noun in النهار ده innaharda (N1).

The feminine distal demonstrative ديك 'that' is used for something that has been mentioned before: ديك الليله 'that night' (N2). Nowadays, the distal demonstratives are ms dukha, fs dikha, and pl dukham/dukhum/dukhumma. ${ }^{34}$ However, until the beginning of the twentieth century, forms without the suffix $h$ - were still found: $d \bar{a} k$, $d \bar{\imath} k, d \bar{o} k,{ }^{35}$ especially in adverbs of time such as $d \bar{\imath} k$ innahār 'that day', ${ }^{36}$ dāk innōba 'that time'. ${ }^{37}$

In N2, 2pl and 3pl forms with - $u$ and -um are interchangeable: نتو and انتم are found in the same sentence; يأَعم yi’a'um.

يئع (N2) may reflect $y i^{\top} a^{c}$, which has been reported in 19th-century texts. ${ }^{38}$ Nowadays, it is pronounced $y u^{\prime} a \cdot{ }^{c}{ }^{39}$ However, it may

\footnotetext{
${ }^{34}$ See Woidich $(2006,46)$.

${ }^{35}$ See for instance Hassan $(1869,88)$. These forms are very old; there are examples such as dik il'uyūn from 14th-century Judaeo-Arabic texts, see Palva (1993, 181-83).

${ }^{36}$ Gairdner (1917, 209).

${ }^{37}$ El-Tantavy (1848, 126).

${ }^{38}$ See, e.g., Spitta (1880, 223), who, however, remarks that it was more common in the countryside than in Cairo.

${ }^{39}$ See Woidich $(2006,81)$.
} 
also reflect $y u^{\prime} a^{c}$, because al-Nadìm mostly wrote the hamza on the $y \bar{a}^{3}$ when occurring in the middle of the word (see above,

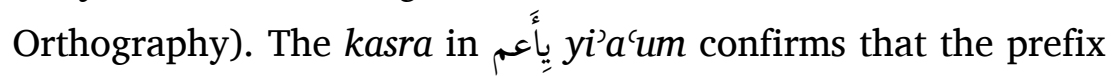
was in fact pronounced yi-.

The future marker is رايح (m), رايحه (f), رايحه تجوزي :رايحين (N1), الراجل اللي رايح يفوت لغته (N1). The shortened form ha- is used in modern Cairene Arabic.

\section{Syntax}

In الحتتين السيغه (N2) the first part of the genitive construction gets the article. This construction, which can also occur with iššuwayyit 'the bit of...' is found in modern Cairene Arabic as well, but is 'substandard'. ${ }^{40}$

احنا يا بنات الشرق فرنساويه والا انكليز: In this sentence, la, the first part of the negation la...wala, is missing.

Both على شان ما and على شان 'in order to', followed by a verb in the imperfect tense, are used in S. Nowadays, the form without $m a$ is more common. ${ }^{41}$

${ }^{40}$ Woidich (2006, 207).

${ }^{41}$ Woidich (2006, 386). 



\section{A DISGRUNTLED BISHOP: A GARSHŪNİ LETTER FROM BISHOP DINḤĀ OF MIDYAT TO PATRIARCH PETER III}

George Kiraz

Beth Mardutho K2005.72-73

Document BM K2005.72-73 belongs to a larger set of documents at the archives of Deir al- Za'farān near Mardin. The archive was digitised between 2005 and 2010 and the digital copies are being preserved at the Beth Mardutho Syriac Institute in New Jersey. The archive consists of ca. 10,000 documents, mostly petitions written to various Syriac Orthodox Patriarchs from Elias II (Patr. 1838-1847) to Elias III (Patr. 1917-1932). The current letter,

\footnotetext{
${ }^{1}$ I am grateful to Mor Philoxenus Saliba Özmen, archbishop of Mardin, for giving me permission in 2005 to digitise the archive. Thanks are due also to Ephrem Aboud Ishac, who read the penultimate version and gave many valuable suggestions. For the historical background of this period, see Dinno (2017), The Syrian Orthodox Christians in the Late Ottoman Period and Beyond: Crises then Revival (Piscataway, NJ: Gorgias Press).
} 
dated 23 August 231882 (Julian), is from Bishop Dinḥā of Midyat and addressed to Patriarch Peter III (Patr. 1872-1894). ${ }^{2}$

We do not know much about Bishop Dinḥā. An account by the contemporary 'Abdallah of Șadad (later Patriarch 'Abdallah, 1906-1915), written in 1870, mentions three monks with this name: Dinhāa of Mashta, Dinḥā of the Monastery of Qarnā in Beth Debe (Badibe), and Dinhāa of Anhil. ${ }^{3}$ While Dolabani, in his history of the Patriarchs (Dolabani 1990), does not mention Peter consecrating a bishop by this name, our Dinhā has been identified by Abraham Garis as the monk from Anhill. ${ }^{4}$ Dinḥā's mother tongue was Neo-Aramaic Tūroyo (Surayt). A native of Mosul, Peter III's mother tongue was Arabic.

It appears that the congregation in Midyat wrote to the Patriarch, complaining about Bishop Dinhāa (lns 6-7). The Patriarch in turn wrote to Dinhāa (lns 4-6) to rebuke him (verso ln. 12). Dinhā then writes back-in this document-to defend himself. The charge seems to be that Dinhā nominated a brother or cousin (or both) to be elected for the Midyat majlis. Per the Ottoman Tanzimat, towns were to have councils with a specific number of Muslims, Christians, and Jews. It appears that the congregation had obtained a firmān from the Porte (الباب العالي) to the effect that only Syriac Orthodox individuals might serve in the Midyat majlis (لا مسلم ولا نصراني غير ملت سريان القديم بس, lns 12-13) which

\footnotetext{
${ }^{2}$ Peter III was later renumbered by Aphram Barsoum as Peter IV, counting the Apostle Peter as Peter I.

${ }^{3}$ I obtained the information about the three Dinhāas from Elio Aydin, who replied to my Facebook post of 24 October 2017.

${ }^{4}$ Reply to my Facebook post of 24 October 2017.
} 
would have caused problems with the local Muslim population (there were no Jews in Midyat). It also seems that some members of the congregation, who were not getting their way, were threatening to convert, most likely to Catholicism (ln. 15). The bishop then goes on to complain about the members of his congregation (lns 16, 23-24, 27-28) and the fact that the Patriarch had sacked him (وايضا عزلتمونا صرنا ممنونين بذلك, ln. 20). He also complains that he has no salary (ln. 24) and asks if he can visit the Patriarch, presumably to discuss his case (ln. 26).

Often letters discuss more than one matter and this document is no exception. After making his complaint, Dinhāa petitions the Patriarch on behalf of one David Efendi, who is apparently working very hard, but going unpaid (verse $\ln .3 \mathrm{ff}$.). "Did his mother give birth to him and offer him a waqf?" Bishop Dinhāa asks sarcastically. The letter ends with Dinhāa asking the Patriarch to save him "from this hell" [فقط نرجو تخلصنا من هذه النار]. A subscript mentions a matter regarding Karburan, a Kurdish-speaking Syriac Orthodox village. It seems that this village was also taken away from Bishop Dinḥā.

\section{Transcription}

\section{Recto}

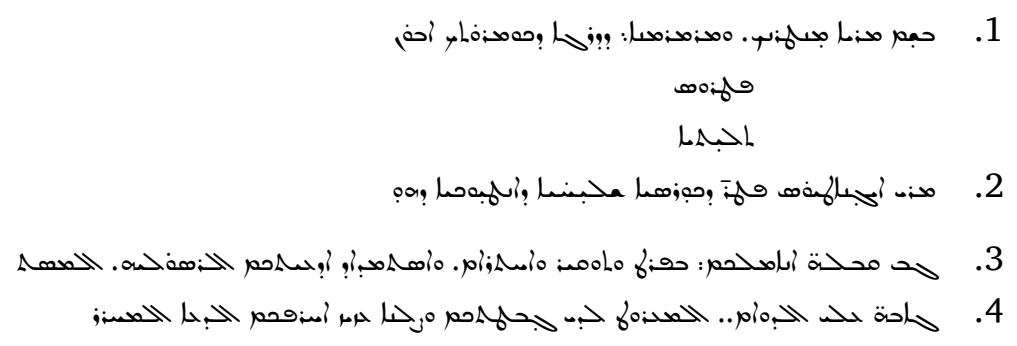


5.

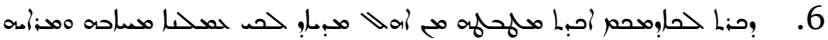
7. 8.

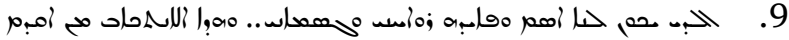

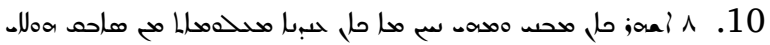

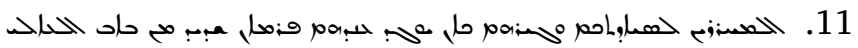

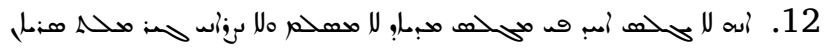

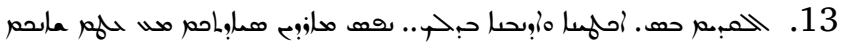

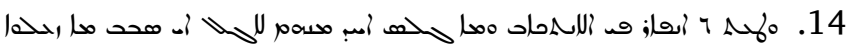

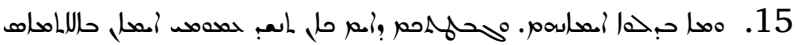

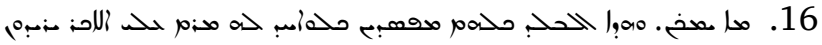

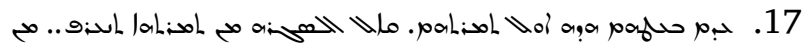

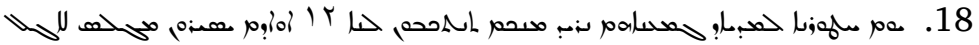

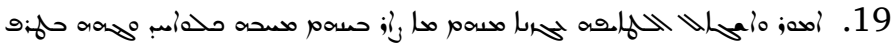

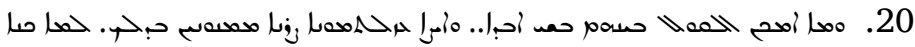

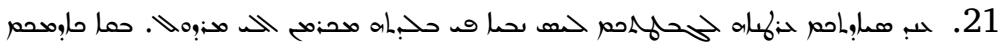

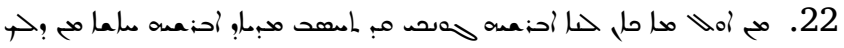

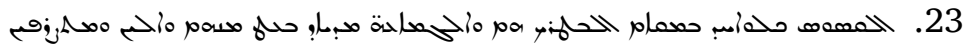

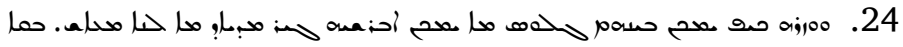

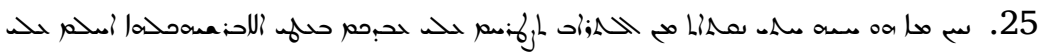

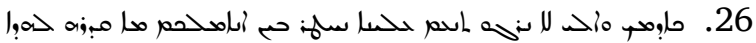

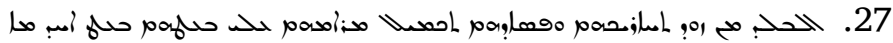

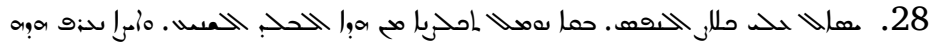

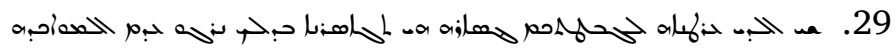

\section{Verso}

1.

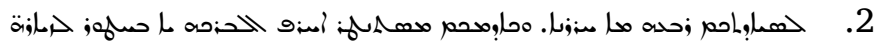

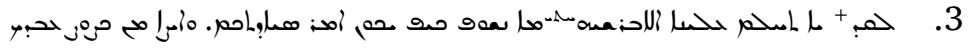

4.

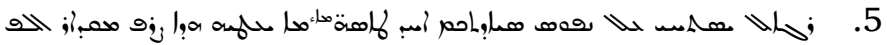



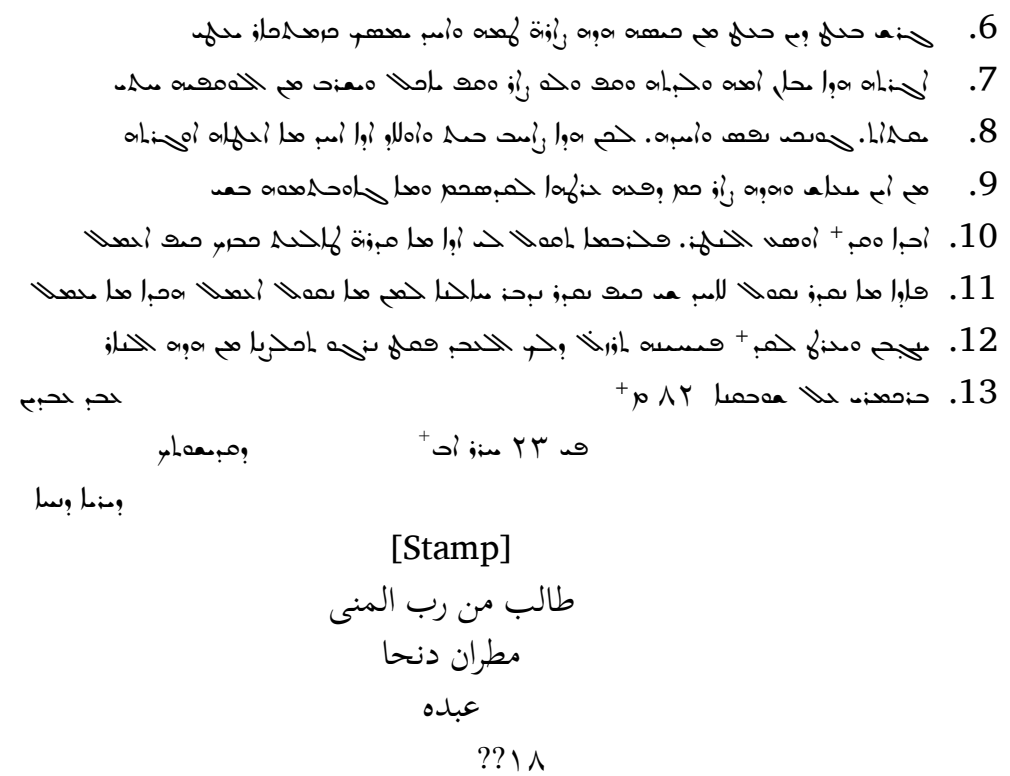

\section{Subscript}

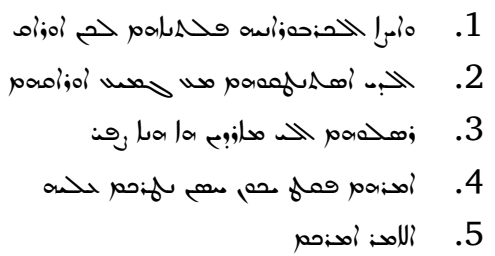

\section{Arabic Transcription}

Syro-Arabic garshunography is a transliteration scheme. As the 22 Syriac consonants are insufficient for the 28 Arabic ones, a number of extensions are used:

1. The bgadkpat letters provide double usage where:
a. $\forall<\mathrm{g}>$ stands for $\mathrm{r}$ and $\dot{\varepsilon}$.
b. , $<d>$ stands for 2 and $\dot{ }$.
c.,$<\mathrm{k}>$ stands for $s$ and $\dot{\tau}$. 


\section{d. $L<t>$ stands for $ت$ and $ث$.}

2. Optional dots may be placed supralinearly to denote the plosives and sublinearly to denote the fricatives. Having said that, the dots are rarely used in this document apart from the following (I use a macron, or, instead of dots in the Latin transliteration

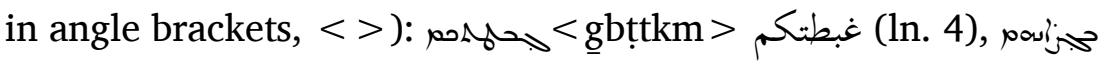

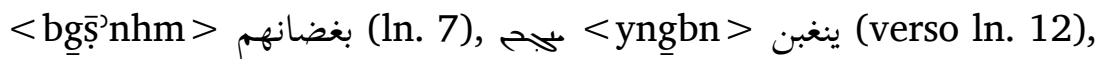

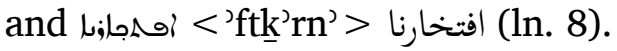

3. As there are no /g/ sounds in Arabic, so $\underset{\nabla}{ }$ is reserved for ${ }^{\text {as }}$ denoted above and may take an optional stroke inside it, $₫$ trans-

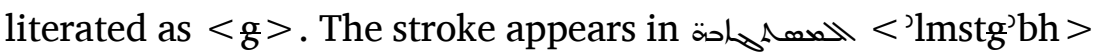

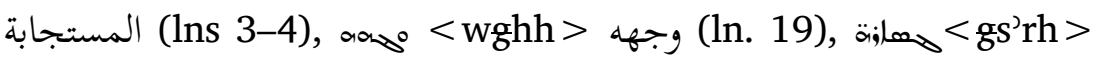
(ln. 29, with three strokes inside $ه$ perhaps to add empha-

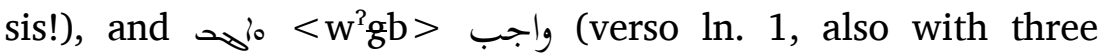
strokes).

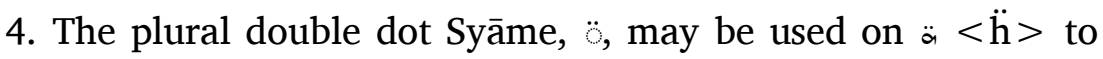
mark $t \bar{a}^{\prime}$ marbūta. The only words to make use of it are: قبلة (ln. 3), عزة (ln. 5), بصحة (ln. 5), والجماعة (ln. 23),

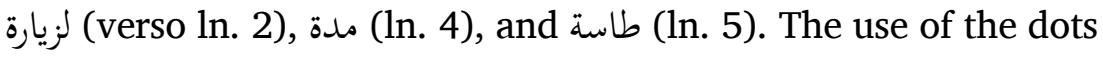
on $\ddot{a}<\ddot{h}>$ for a proper صارة $ت$ appears in صارة (verso ln. 6). Inversely, we have سلامت سلامة (ln. 5).

5. An optional dot inside $\gamma<t>$, $\gamma$, denotes but this is never used in the document; e.g., we have undotted of مof < mṭth > (i.e., written as مظبطة for. Note that in Jazireh Arabic, many words with correspond to MSA words with ض فظة (cf. MSA (مضبطة). 
6. An optional dot above j denotes $ض$ and appears only in pouj

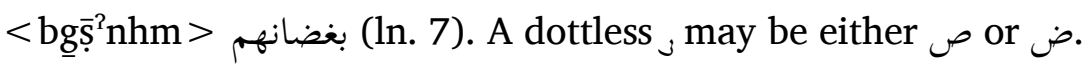

Garshūnī writing sometimes uses Arabic vowels. Due to typographical constraints, these are not given in the Syriac-script text above, but are given in the Arabic script below. ${ }^{5}$

\section{Recto}

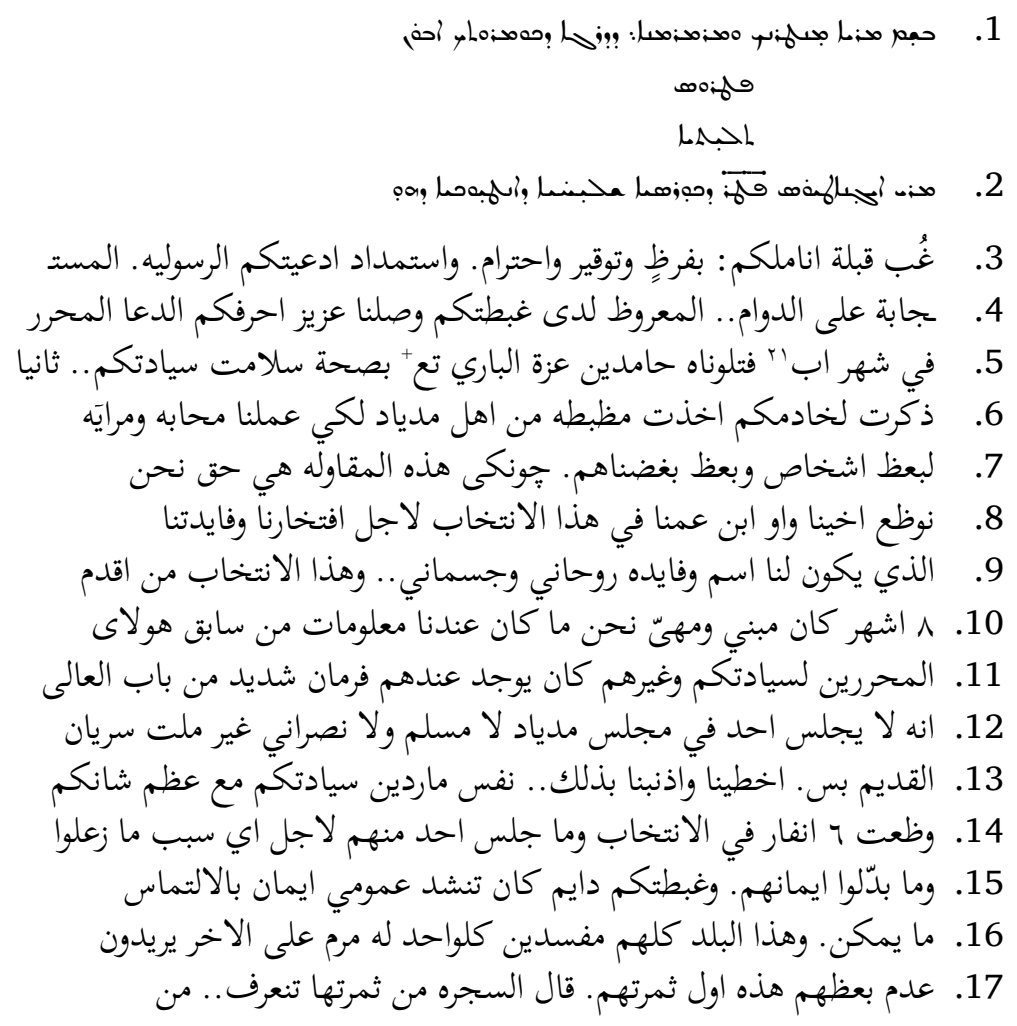

${ }^{5}$ Microsoft Word 2000 up to XP allowed one to add Arabic diacritics above Syriac-script text, but it seems that later versions do not permit this! As of May 2021, one can write Arabic diacritics on Syriac using Notepad and then copy the text into Word, though this risks the text being broken during typesetting by publishers. 


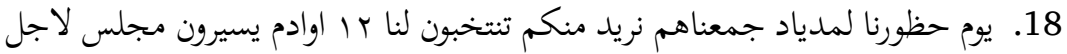

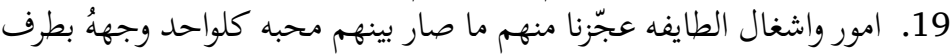

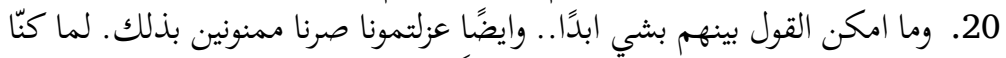

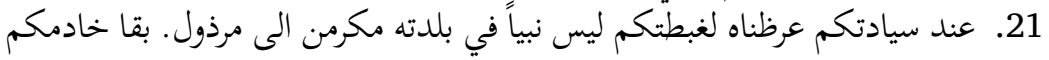

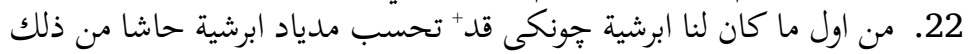

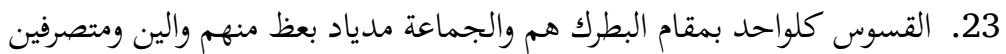

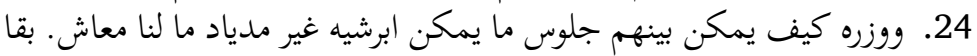

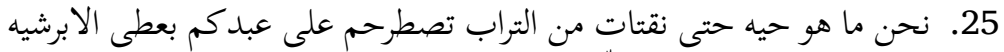

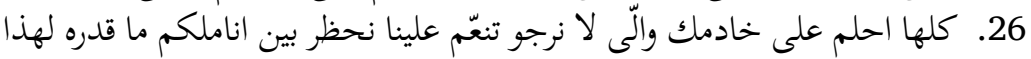

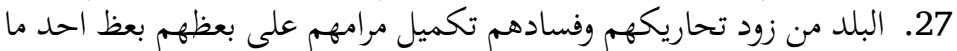

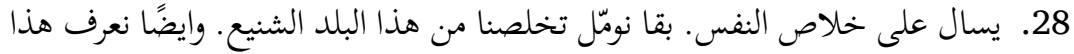

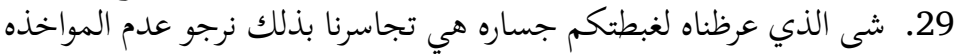

\section{Verso}

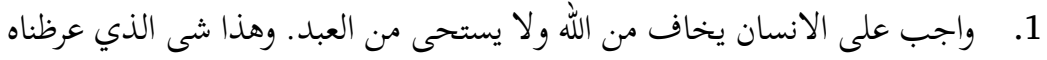

2.

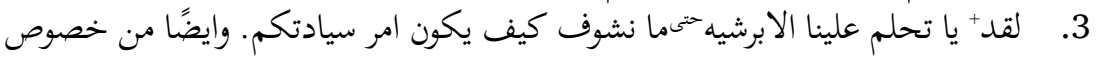
عبدك

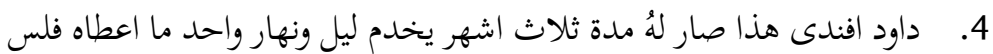

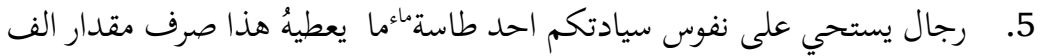

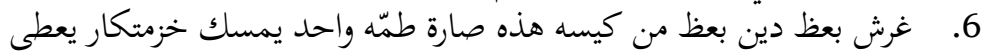
7.

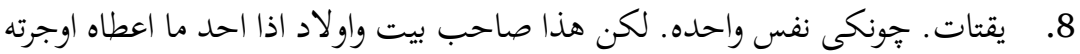

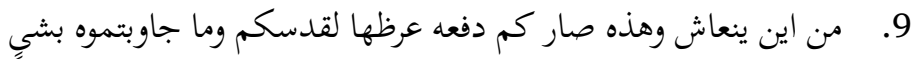

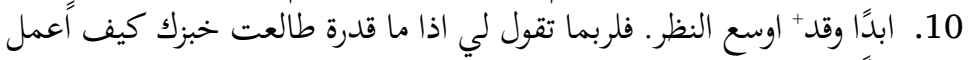

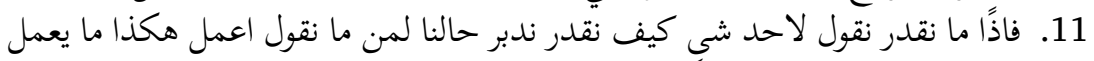

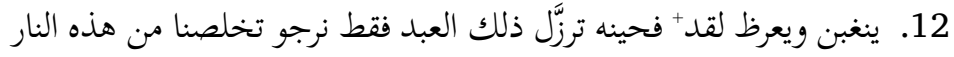

$$
\begin{aligned}
& \text { حרו: רבויה } \\
& \text { في זr حرر اب+ }
\end{aligned}
$$

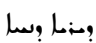

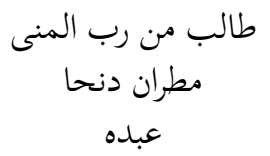

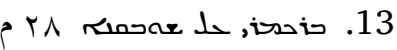




\section{Subscript}

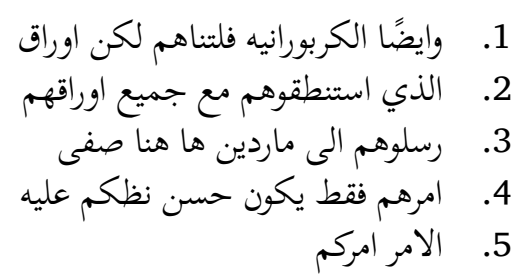

\section{Translation}

\section{Recto}

(1) In the name of the Lord your protector and the exalter of the rank of your high-priesthood, our Father, (2) Mor Ignatius, Patr[iarch] of the Apostolic See of Antioch, who is (1.5) Peter III.

(3) After kissing your fingertips with duty, honour, and respect, and procuring your Apostolic blessings which are answ(4) ered all the time. It is petitioned to Your Beatitude:

We have received your precious letter [عزيز احرفكم], the supplication [الدعا], written (5) on 21 August. We read it praising the Almighty [عزة الباري تعالى سلامت] for the well-being of your Lordship.

Secondly, (6) you mentioned to your servant that you received a petition [مظبطة] from the inhabitants of Midyat, (complaining) that we have loved and favoured [عملنا محابه ومرايَه] (7) some individuals and hated others. Çünki, is this claim just

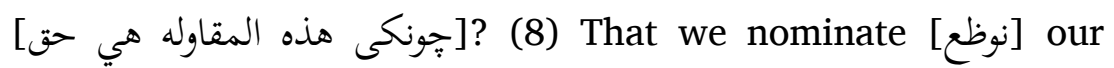
brother and/or paternal-cousin to this election for our own pomp and benefit? [الاجل افتخارنا وفايدتنا To gain a name [9 الذي يكون لنا [اسم and benefit both spiritually and materially? 
And this election (10) was set and prepared [مبني ومهيّ]] 8 months ago من اقدم]. We had no information beforehand. Those (11) who wrote [هولاى المحررين] to your Lordship and others possessed [كان يوجد عندهم] a strong firmān from the Porte (12) stating that no one is to sit in the majlis of Midyat, be he a Muslim or a Christian, unless he belongs to (13) the Old Syriac millet only [بس]. We have transgressed and are guilty of this... Even Mardin itself, despite the great significance of your position [نع عظم] (انفارر] for the election. And not even one of them succeeded [جلس (نفارطا], for whatever reason. They did not become upset [ما زعلوا] (15) nor did they change their faith [وما بدّلوا ايمانهم]. And Your Beatitude always implored publicly that faith by solicitation [تنشد عمومي ايمان بالالتماس] (16) is not possible [ما يمكن]. And this region [البلد, i.e., Midyat], all of (its people) are malicious [مفسدين], each one takes a shot at the other [كلواحد له مرم على الاخر]. They seek (17) to destroy each other [عدم بعظهم]. This is the first of their fruit. He said, "The tree is known by its fruit."

Since (18) the day of our arrival in Midyat, we gathered them. "We want you to elect 12 individuals [وادم] to form a majلاجل امور[ [عجّزنا] of them. There is no love amongst them [ما صار بينهم مححبه]. Each one disagrees with the other [كلواحد وجههُ بطرف, lit. 'each one looks to a (different) side']. وما امكن القول بينهم] Talking to them did not achieve anything بشي ابدًا]

${ }^{6}$ This would be a parish majlis, to be distinguished from the secular town majlis. 
Also you dismissed us (from office) [عزلتمونا] and we are much obliged [صرنا ممنونين] for this! When we were (21) with your Lordship, we presented to Your Beatitude that "No prophet is revered in his town, but is reviled." Therefore [بق], your servant (22) had no diocese from the beginning. Çünki, does Your Holiness consider Midyat a diocese? God forbid [حاشا من ذلك ]! (23) The priests: each one of them considers himself a patriarch. They, along with the people of Midyat: some of them are wălis, mutasarrifs, (24) and wazirs. How can one live with them [يف يمكن [بينهم جلوس ? It is not possible (in any) diocese, except Midyat!

We don't have a salary. Well [بقا], (25) we are not a snake to eat from dirt. Have mercy [تصطرحم] upon your servant [عبدم:] by giving [us] the (26) entire diocese. Have clemency [احطم)] uماحم)] upon

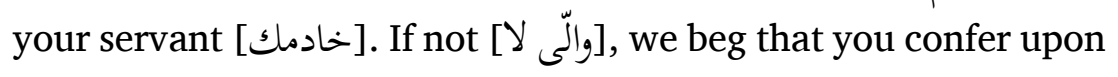
us [نحظر بين] to be present in front of your fingertips [اناملكم. It is not possible to endure this (27) region due to the amount of their incitements and wickedness [تحاريكهم وفسادهم],

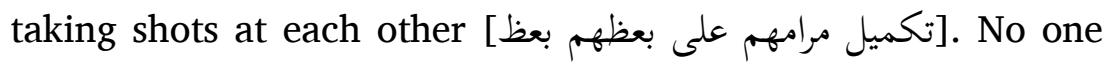

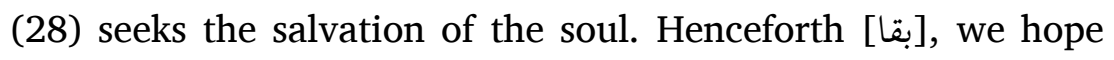

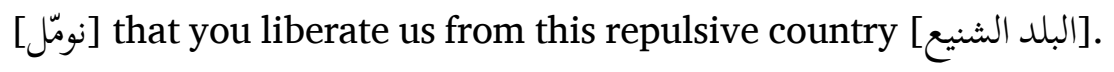

Additionally, we recognise [نعرف] that the (29) matter with which we are petitioning Your Beatitude is bold [جساره هي]. We have been bold [تجاسرنا بذلك]]. We beg for pardon نرجو عدم] [المواخذة. 


\section{Verso}

(1) It is one's duty to fear God and not to be ashamed of the servant. It is about that that we have petitioned your (2) Lordship. We have not written a quarter of it. And your servant is awaiting [مستنظر] the words of blessings [حرف البركه, i.e., a reply], either by visiting (3) your holiness, or for the diocese to have mercy [تحلم علينا الابرشية] until we see what the order of your Lordship is.

And also regarding your servant, (4) David Efendi: he has been serving, day and night, for three months and no one gave him a single fils. (5) He is a man who is envious for the sake of your Lordship [رجال يستحي على نفوس سيادتكم]. No one gives him a glass [طاسة] of water. This one spent about one thousand (6) ghirsh, some from a loan, some from his own pocket. This became a disaster [طمة]. (Even if) one hires [يمسك] a servant [خزمتكار], he pays [يعطى] (7) his salary. It seems that his mother gave birth to him as a waqf. And even if he was a waqf, he should eat and drink from the waqf (income), so he can (8) live. Çünki, is he only one person? But he is the head of a household [صاحب بيت] and children. If no one gives him his salary, (9) how would he live? And how many times [دفعه] did he petition your holiness and you did not answer him at (10) all. And Your Holiness is more prudent [اوسع النظر] (than this). Maybe you say to me, "if you cannot اذا ما قدرة طالعت خبزك كيف] "win your bread, how can you help? [اعمل (11) If we are unable to say anything (i.e., give orders) to anyone, how can we manage [ندبر حالنا]? To whomever we say, 
"do this" he does not do it, (12) gets upset [ينغبن], and then petitions your holiness. Then you rebuke [ترزّل] beseech you to save us from this flame.

(13) Barekhmor for forgiveness! [18]82 AD servant of servants

22 August of your holiness

Monk Dinhāā

[Stamp: Bishop Dinhāa]

\section{Subscript}

(1) Also, regarding those of Karburan: we left (the administration to) them [فلتناهم]. But the papers of (2) their affidavits [وراق الذي]

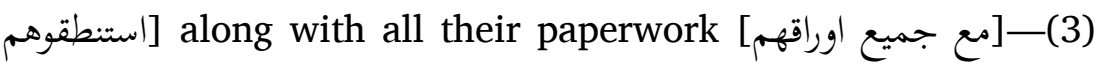
they sent them to Mardin. Here, their business is concluded [o [هنا صفى امرهم (i.e., as far as I am concerned). (4) Only (i.e., we wish that), may you protect them [يكون حسن نظكم عليه. (5) The command is your command.

\section{Commentary}

\section{Line 1}

It is common to address the Patriarch in Syriac and end with $B a$ rekhmor $^{7}$ (verse ln 13).

Line 3

غِبْ 'after' (al-Bustānī 1930, II:1617).

extends from ln. 3 to ln. 4.

${ }^{7}$ For the use of liturgical barekhmor as a greeting, see Borbone (2015, 479-84). 
Line 4

(احرف البركة , (and verso ln. ). Such terms designate letters written by the Patriarch. One may refer to one's own letter addressed to a Patriarch as احرف العبودية.

Line 5

تع Abbreviation for تعالى. A supralinear line, sometimes with a vertical stroke, denotes an abbreviation or number.

مسلامت Orthographic variant for سلامة.

Line 6

= محابة DSA محبّة

\section{Line 7}

T: Turkish çünki (also ln. 22 and verso ln. 8) = modern çünkü. It is consistently used here as an interrogative, with a disapproving tone, where the answer is negative.

. There is either a scribal error involving repetition of واخينا وابن عمنا in which case, read) or a conjunction has been prefixed to $\mathrm{g}$.

Line 10

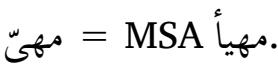

هولاى / هو / هو of Mardin) = MSA هؤلاء.

Lines 12-13

. This refers to what we call today Syriac Orthodox. The designation قديم في و the older Syriac Orthodox from the then newly separated Syriac Catholics.

Line 13

بس bas/. Colloquial for 'only'. 
اخطينا = أخطأنا

Line 17

السجرة من ثمرتها تنعرف = سجرة = MSA شجرة 6.44);

Line 18

مجلس. This is a parish majlis 'council' rather than the town's secular majlis.

يسيرون. Probably /yusayyirūn/ 'to manage', but <s> could have been written for /ṣ/ to form /yașīrūn/ 'to become'.

Line 19

محب An orthographic calque from Syriac . كل واحد = كلواحد

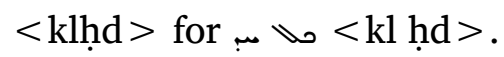

Line 21

ليس نبيا في بلدته مكرمن (Luke 4:24). Notice the use of ن for tanwin.

Line 25

= MSA تصطرحم.

Line 26

والّ = MSA والّ

Line 28

= نومّل MSA نأمل 'we hope/wish'.

Verso

Line 3

بالابرشية The phrase is not clear, if we assume, the sense would be 'or to have mercy upon us by (giving us) the diocese'.

Line 5

طاسة colloquial 'cup'. 
Line 6

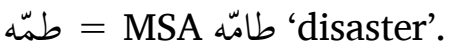

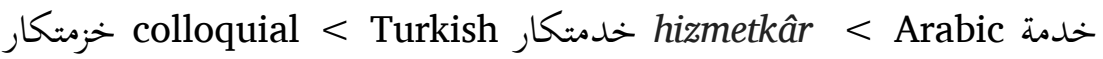
'service' + Persian كار 'worker, i.e. servant' 'Īsā ([1911, 255] 2016, 136).

Line 8

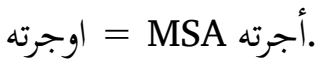

Line 9

= ينعاش MSA. 


\title{
33. AḤMAD B. MUḤAMMAD AL-JARĀDİ: SİRAT AL-KֵAWĀJA AL-'AKRAM AL-MARḤŪM HARMĀN AL-'ALMĀNİ
}

\author{
Alex Bellem and G. Rex Smith
}

The text is a report written by the Șan'ānī secretary of Hermann Burchardt, a German traveller and photographer. Burchardt was murdered by bandits in December 1909 near Ibb in the Yemen (Mittwoch 1926), along with the Italian consular official Benzoni (Farah 2002, 238-39). ${ }^{1}$ Perhaps in response to a request for details of the journey and the murder, al-Jarādī (henceforth $\mathrm{J}$ ) produced this report for the German and Italian authorities in Ottoman Yemen in early 1910. The text below is that edited by Eugen Mittwoch in 1926 from two manuscripts which, he states, are in Berlin and the Ambrosiana in Milan and which appear to have been written at different times and without connection one with the other (Mittwoch 1926, 6-7). The MSS are so far untraced and the text below is an exact copy of Mittwoch's edition. The

\footnotetext{
${ }^{1}$ He had undertaken several expeditions in Ethiopia and Yemen, some authorised, others not. When the Italian authorities insisted that the Sublime Porte find and punish the murderers, the Ottomans branded Benzoni a spy.
} 
language is clearly Literary Mixed Arabic (LMA) and is dealt with in some depth below.

\section{Transcription}

Mittwoch (1926, 16.3-18.5)

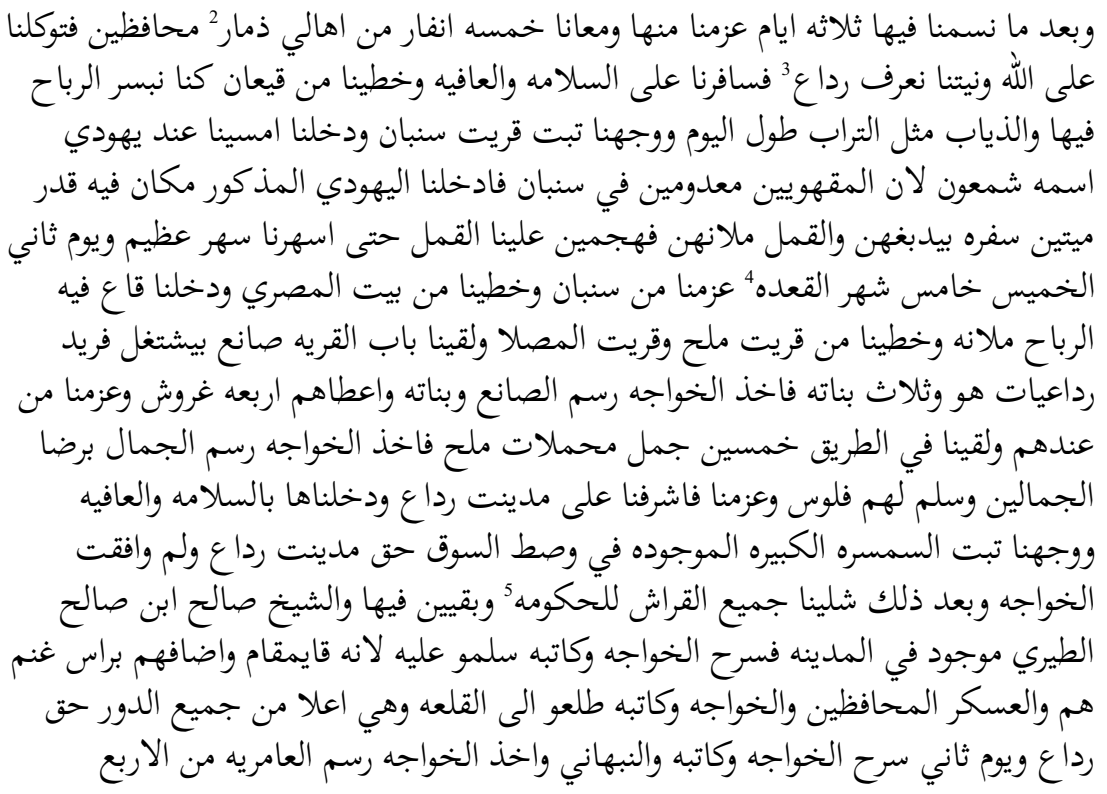

2 Damār is a town some 50 miles due south of Șan(ā') al-Hamdānī (1884-1891, 55, 80, 104, etc.), Yāqūt (1979, III:7). Interestingly, it has the $f a^{\prime} a \overline{l i}$ pattern, along with other place names in the Arabian Peninsula, like Zafār, the medieval town on the southern coast of Oman, now the name of the whole southern province of Oman; Smith (2004, 26480, 276-77).

${ }^{3}$ A town about 35 miles due east of Damār; Hamdānī (1884-1891, 55, 93 etc.); Smith (1974-1978, II:193), with full references. It may also be in the $f a^{\prime} \bar{a} l i$ pattern.

${ }^{4} 5$ D̄ū al-Qa'da $=18$ November 1909.

${ }^{5}$ This must refer to the government building. 


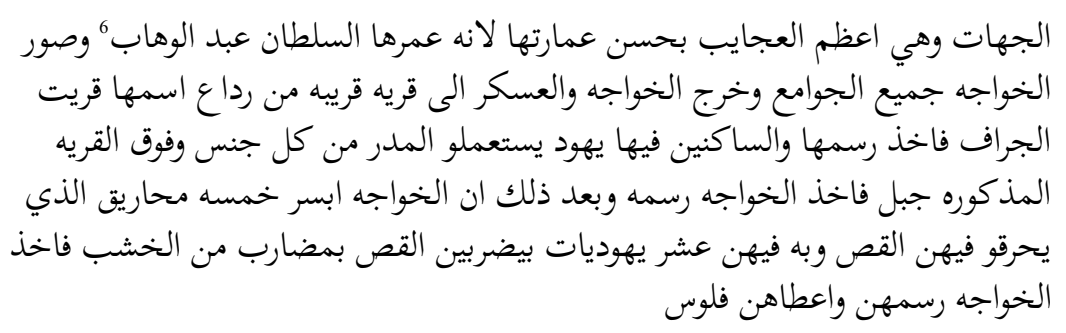

\section{Translation}

[16] After we had taken our rest there for three days, we left, accompanied by five Damārīs as guards. We set off with the intention of getting to know Radāc. We journeyed feeling safe and sound. We made our way through plains in which all day long we could see numerous baboons and wolves. We travelled in the direction of the village of Sanbān. ${ }^{7}$ We entered and stayed the night in the house of a Jew called Simon, since there were no innkeepers in Sanbān. This Jew showed us into a room in which there were two hundred untreated hides with the hair still on them which he tans; they were full of lice. These lice attacked us and we just could not sleep. The next day, Thursday, 5 [Dū] alQa'da, we left Sanbān and made our way through Bayt al-Mișrī and entered a plain full of baboons. We passed through the villages of Milh and al-Muṣallā, coming across at the village gate

${ }^{6}$ Al-Manșūr 'Abd al-Wahhāb, third Tahirid sultan, 883-894/14781489; see Smith, (1988, 129-39, 137, 139). J is wrong here! The 'Āmiriyya mosque and madrasa were built in $910 / 1504$ by the first Tahirid sultan, al-Zāâir 'Āmir (reg. 858-864/1454-1460); on the mosque's architecture mosque, see Porter (1992; 2017); Al-Radi (1997). ${ }^{7}$ We vocalise thus, although we can find no reference to the village in the geographical sources at our disposal. 
someone working on Radā'ì rugs, he and three of his daughters. The gentleman took photographs of the workman and his daughters and gave them four piastres. We left them and en route met fifty camels laden with salt. The gentleman took a photograph of the camels with the consent of the cameleers and gave them some money. We pressed on and came to the town of Radāc. We went in feeling safe and sound and made our way to the large caravanserai situated in the middle of the town market of Radāc. But it was not to the liking of the gentleman and we then took all the animals to the government building, where they remained. Now Shaykh Ṣāliḥ b. Ṣāliḥ al-Ṭayrī was in town, so the gentleman and his secretary went to greet him, since he was governor. He gave them a meal of a goat, them and the guards. The gentleman and his secretary climbed up to the citadel, the highest building in Radāc. The next day [18] the gentleman, his secretary, and alNabhān $\bar{i}^{8}$ went and the gentleman took photographs of the 'Āmiriyyah from all sides, it being the greatest wonder because of the beauty of its construction, having been built by Sultan 'Abd al-Wahhāb. The gentleman photographed all the mosques and he and soldiers left for a nearby village called al-Jirāf. He took photographs of it. Its inhabitants are Jews, who make clay pots of all kinds. Above this village is a mountain which the gentleman photographed. Then he noticed five kilns where they were burning lime and where there were ten Jewish women who were beating

${ }^{8}$ Earlier in the text (Mittwoch 1926, 10), J identifies Husayn b. Muḥammad al-Nabhānī as a gendarme of the Zaydī tribe of Arḥab, appointed from the start of the expedition as Burchardt's escort. 
limestone with wooden mallets. The gentleman took their photograph and gave them money.

\section{Commentary}

Line 1

nasam 'rest, take rest' (Landberg 1920-1942, III:2767; Piamenta 1990-1991, II:484).

'azam min 'depart, leave' (Lane 1863-1893, 2037-38; form I = CA form VIII, with a Yemeni source; Landberg 1920-1942, III:2289; Piamenta 1990-1991, II:326).

tawakkal 'alā Allāh 'set off, out'; often reduced to tawakkal in the Yemen (Piamenta 1990-1991, II:531).

Line 2

hați 'make ones way' (Piamenta 1990-1991, I:32; Qafisheh 2000, 175; Watson 2000, 313).

ribhii, plural rubāh, ‘baboon' (Landberg 1920-1942, II:1061).

'absar/'abșar 'see'; SA, and indeed Yemeni Arabic (YA) in general, allow both forms (Piamenta 1990-1991, I:32).

Line 3

tabt, tibt (or tabt) 'in the direction of' (Rossi 1939, 245; Serjeant and Lewcock 1983, 562); perhaps < tabb, tubūb 'row, line' (Landberg 1901, 264).

maqhawì 'keeper of small inn (maqhāya/makhāya)'. Smaller than a samsara (Rossi 1939, 143; Landberg 1920-1942, III:2538; Piamenta 1990-1991, II:416). 
Line 4

sufra 'hide, untreated and with the hair still on it' (Rossi 1939, 226; Piamenta 1990-1991, II:224).

\section{Line 6}

farda, plural farīd, 'rug, mat' (Landberg 1920-42, III:2406; Piamenta 1990-1991, II:369).

Line 8

'ašraf 'alā 'reach, come to' (Landberg 1920-1942, III:2042; Mittwoch 1926, 66).

Line 9

samsara, plural samāsir, 'caravanserai'. Larger than a maqhāya, (Serjeant and Lewcock 1983, 592; Piamenta 1990-1991, I:232).

Line 10

šall 'take' (Landberg 1920-1942, III:2073); Goitein 1941, Glossary, 89; Piamenta 1990-1991, I:263).

qāriša, plural qirāš, 'animals' in general, but often used of cattle. Here we take it to mean Burchardt's riding animals, perhaps donkeys or mules, or both (Landberg 1920-1942, III:2474; Piamenta 1990-1991, II:393).

saraḥ 'go' (Piamenta 1990-1991, I:220).

Line 11

qāyimaqām, 'governor' (Redhouse 1890, 1429).

Line 14

ista'mal 'make'; this meaning of the verb is not CA, nor does it find a place in the Yemeni lexicographical literature at our disposal, though Dozy (1881, II:157) gives us fabriquer. 


\section{Line 15}

miḥrāq, plural maḥārīq, 'kiln' (Piamenta 1990-1991, I:90).

Line 16

quṣs /qișs usually appears as jușs /jișs in CA (Lane 1863-1893, 428), as well as in the vernaculars (Piamenta 1990-1991, II:6768); from the Persian gaj or kaj (Steingass 1930, 1016, 1074).

\section{Linguistic Notes}

The text is written in LMA and contains a mixture of Classical Arabic (CA) and Șan'ānī Arabic (SA), also including the use of purely CA features used outside the accepted norms of CA grammatical norms. ${ }^{9}$ Before the detailed linguistic observations below, three general features of the grammar of the text may be highlighted here.

1) the masculine plural nominal and adjectival ending in the oblique case -in in all grammatical environments; e.g., li-anna almaqhawiyyin ma'dūmin fi sanbān 'because there were no innkeepers in Sanbān' (ln. 3);

2) the complete lack of 'alif al-tanwin; e.g., 'asharnā sahar 'azim (ln. 5);

3) the complete lack of 'alif al-wiqāyah; e.g., yasta'milū (ln. 15). Items of lexical interest are dealt with in the Commentary above. The following linguistic observations are presented line by line, as they occur in the Arabic text.

\footnotetext{
${ }^{9}$ For a fuller discussion of LMA and its features, see Bellem and Smith (2014, 9-10).
} 


\section{Line 1}

$m a^{`} \bar{a}-n \bar{a}$. SA has $m a^{\complement} \bar{a}$-hā with the 3 fs pronominal suffix and $m a^{c} \bar{a}-$ with all plural pronominal suffixes (Watson 1993, 196).

Lines 1-2

wa-niyyat-nā na'rif radā' literally 'our intention [was] that we get to know $\operatorname{Rada} \bar{a}^{\text {'. }}$ No verb 'to be' is expressed and the subject noun (niyyat-nā) is linked to the verb (na'rif) asyndetically.

\section{Line 2}

kunnā nubsir al-rubāh fi-hā is thus a relative clause whose antecedent is qī $\bar{a}$.

Line 3

wa-wajjahnā. Form II = CA form V, wa-tawajjahnā.

wa-dahalna 'amsayna 'we went in and spent the night'. The two verbs are linked asyndetically.

Line 4

miyatayn sufra '200 hides'. The first part of the iḍaffah construction retains the final nūn of the dual ending.

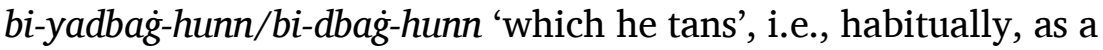
profession. The $b i$ - prefix with the prefix conjugation verb "expresses continuous and habitual aspect" (Watson 1993, 62, 78 ff.); "une valeur de concomitance" (Naïm 2009, 72). The feminine singular antecedent, sufra, is followed in the asyndetic relative clause by the feminine plural pronominal suffix -hunn.

fa-hajjamayn 'alay-nā 'they (feminine plural) attacked us'. The feminine plural suffix conjugation is always -ayn in SA (Watson 1993, 56). The collective noun qaml serving as subject following 
the plural verb hajjamayn is construed as a feminine plural here and in the previous sentence, wa-l-qaml malān-hunn.

'asharnā. Form IV = CA form I, sahirnā, followed by a cognate accusative, sahar 'ažim.

Line 5

yawm tânin, for al-yawn al-tânin, is used commonly in the text.

Line 6

bi-yaštag̈il/bi-štagiil; see above, ln. 4.

The plural noun farid is qualified by the feminine plural adjective radā'iyyāt.

\section{Line 7}

hamsin gamal muhammalät milh. The numeral is followed by the singular noun ğamal, which is then qualified by the feminine plural participle muhammalāt.

Line 9

fi wasat al-sūq. The șād replaces the CA sin in pronunciation because of the following emphatic țā'.

al-sūq haqq madinat radāc 'the market of the town of Radā'. An example of the common analytic genitive; haqq is the only possessive linker used in YA (Naïm 2009, 115-16); it can be declined (Behnstedt 1987, 62).

wa-lam wāfaqat al-hawāğa 'but it [the samsara] was not to the gentleman's liking'. Lam with the suffix conjugation negating past time-a common feature in J's text. 
Line 10

šallayn $\bar{a}$ 'we took'. For the vernacular suffix conjugation of the doubled verb, see Bellem and Smith $(2014,12)$. Watson (2009, 114) proposes that the form is due to an '-ay-' infix rather than the common interpretation, that a geminate verb in the vernacular is, as it were, turned into a verb with third radical $y \bar{a}^{3}$ and the gemination retained.

Lines 10-11

fa-sarah al-hawāăga wa-kātibu-h sallamū 'alay- $h$ 'the gentleman and his secretary went and greeted him'. Note that sallamū is plural here and linked asyndetically to the preceding clause.

\section{Line 11}

wa-l-hawāğa wa-kātibu-h țala'ü 'ilā al-qal'a 'the gentleman and his secretary climbed up to the citadel'. The form tala' $\bar{u}$ is plural.

\section{Line 12}

jamī' al-dūr ḥaqq $\operatorname{rad} \bar{a}^{c}$ 'all the buildings of $\operatorname{Rad} \bar{a}$ '. See above, $\ln$. 9.

\section{Line 13}

li-anna-hu 'amar-hā al-sulțān 'abd al-wahhāb 'because Sultan 'Abd al-Wahhāb built it'. Note the ḍamir al-ša'n, here in bold.

Lines 15-16

'absar hamsa maḥārīq allad̄i yaḥriqū fi-hinn al-quṣ̣ 'he saw five kilns in which they were burning limestone'. In an interesting example of mixed Arabic, the indefinite antecedent mahāriq (grammatically feminine singular?) is qualified by the relative clause introduced by alladi followed by the feminine plural pronominal suffix -hinn. The form alli is the usual SA relative pronoun, irrespective of the number and gender of the antecedent 
(Naïm 2009, 121); alladī is the only relative pronoun used throughout the text.

Line 16

bi-yaḍribayn/bi-ḍribayn. See ln. 4 above. 



\title{
34. ORA VE-SIMḤA (1917) ${ }^{1}$
}

\author{
Esther-Miriam Wagner
}

\section{Transcription}

בעד דאך בדאת לקהל תצללי פי שחרית וכדא דאך לחסיד סידור מתע אצלה פי ידוידהו

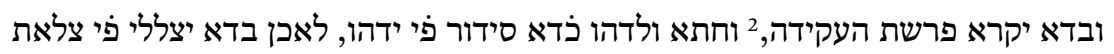

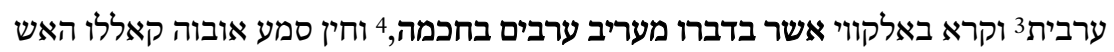

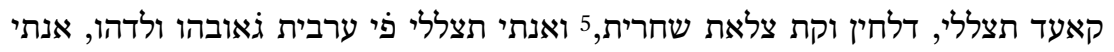

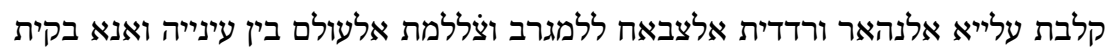

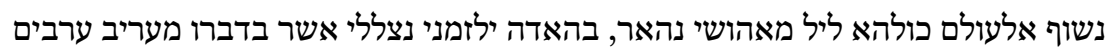

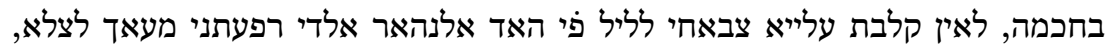
ורעדתני בכלאמך.

\section{Arabic Transcription}

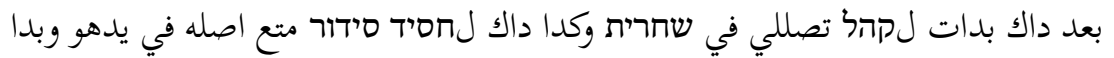

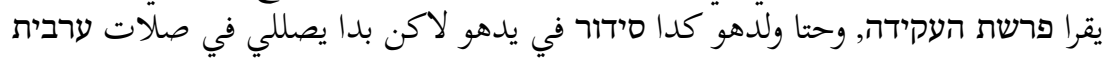

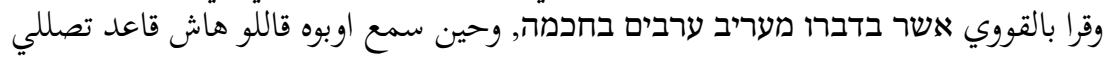

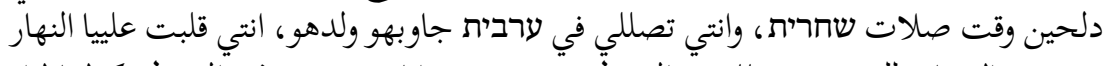

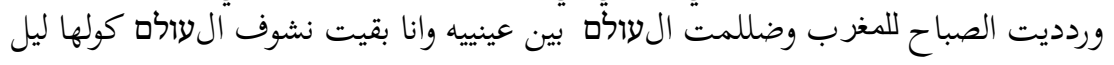

${ }^{1}$ Taken from the book Ora ve-Simha published in Jerba in 1917. I received this book as a present from Dr Melonie Schmierer-Lee, who purchased it on Ebay.

2 The binding of Isaac.

${ }^{3}$ Evening prayer.

${ }^{4}$ Opening of daily evening prayer.

${ }^{5}$ Morning prayer. 


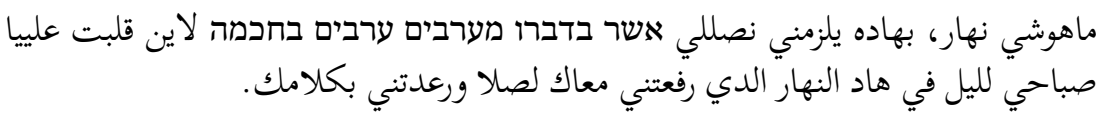

\section{Translation}

After this, the community began to pray the morning prayer. The pious man had an original prayer book in his hand. He began to read the Parasha ha-Aqedah. His son also had the prayer book in his hand, but he began to pray the evening prayer and read with force the opening of the prayer. When his father heard (this), he said to him: "What are you praying? Whereas this is the time for the morning prayer, you are praying the evening prayer." His son replied to him: "You turned the day upside down for me, and the morning has been brought to the West, and the world has grown dark before our eyes. I began to see the whole world at night not day, and therefore I must pray the opening of the evening prayer. You turned my morning into night on this day, on which you took me with you to prayer and you made me tremble with your words."

\section{Commentary}

לחסיד and community and the pious man are the subjects in these clauses, so these are clear examples that here and in other places the article is spelled only with lām instead of a ligature of 'alif and lām.

Geminated consonants are expressed through double spelling, as in תצללי 'prays', וצללמת 'darkened', and ורדדית 'has been brought'. The phrase מתע אצלה is somewhat unclear. מתע is the Maghrebian particle expressing belonging, aṣl conveys 'origin, root'. I have 
translated this as 'original', as this made the most sense in relation to the following story.

'what'. A contraction of an emphatic particle ha- and Maghrebian $a \check{s}$.

The root $q^{c} d$ is used as an auxiliary verb to express present continuous action.

The verb baqa is used as an auxiliary verb to express the start of an action.

The short passage, as well as the whole book from which the excerpt is taken, contains a large range of unusual connectives. For example, bash is used to express 'so that'.

מאהושי 'is not'. 



\title{
35. A 'MAND ÆO-ARABIC' LETTER FROM LADY DROWER'S CORRESPONDENCE
}

\author{
Charles Häberl
}

\section{Transcription}

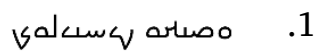

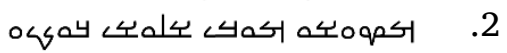

$$
\begin{aligned}
& \text { \山্ك ك } 3 \\
& \text { 4. } \\
& \text {.4 } 5 \\
& \text { 6 } \\
& \text { o }
\end{aligned}
$$

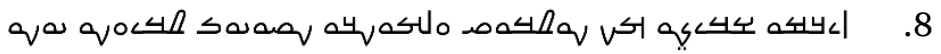

$$
\begin{aligned}
& \text { 9. } \\
& \text { 10. } \\
& \text { 11 } \\
& \text { So< 나 12 } \\
& \text { 13. } \\
& \text { |كمبك 14 . 15 . }
\end{aligned}
$$

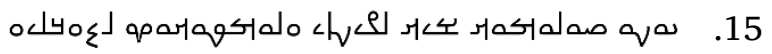

$$
\begin{aligned}
& \text { 16 } \\
& \text { q<por var|d ل17 }
\end{aligned}
$$

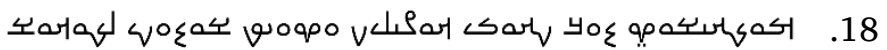

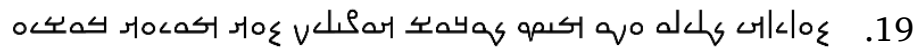

$$
\begin{aligned}
& \text { 20. }
\end{aligned}
$$

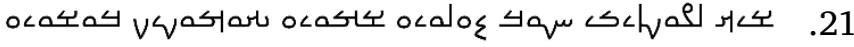

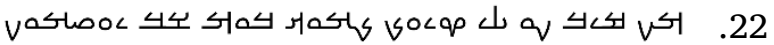




\section{Arabic Transcription}

$$
\begin{aligned}
& \text { 1 - ماسوثا نيهويلاخ }
\end{aligned}
$$

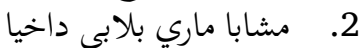

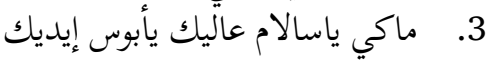

$$
\begin{aligned}
& \text { 4. } \\
& \text { 5. }
\end{aligned}
$$

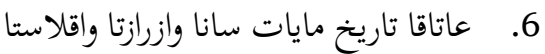

$$
\begin{aligned}
& \text { 7. }
\end{aligned}
$$

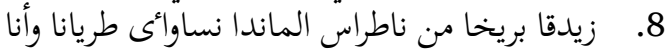

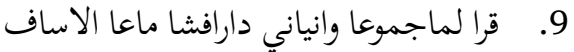

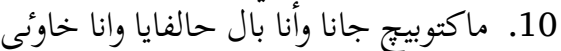

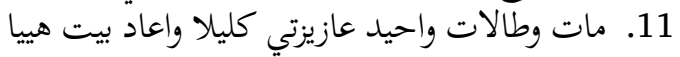

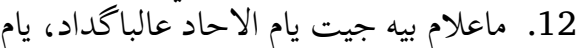

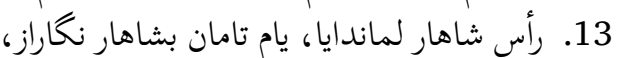

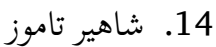

$$
\begin{aligned}
& \text { 15. 15. وانا سالامات تاوز بيت لكينزي الامفاتاش لعادليا } \\
& \text { 16. 15. ميستار دراوار }
\end{aligned}
$$

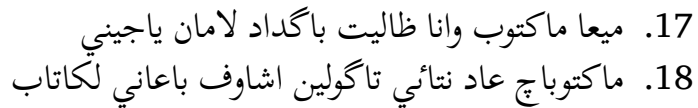

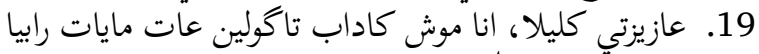

$$
\begin{aligned}
& \text { 20. } \\
& \text { 21. }
\end{aligned}
$$

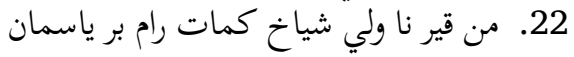

\section{Translation}

(1) May you have health! ${ }^{\mathrm{M}}(2)^{\mathrm{M}} \mathrm{I}$ praise God with my pure heart. ${ }^{\mathrm{M}}$

(3) Makki says hello, he kisses your hand. (4) Klila Shishyan, ${ }^{\mathrm{M}}$ may you have good health. ${ }^{\mathrm{M}}$ Your letter (5) has arrived, and I am grateful. I brought a large, (6) ancient Treasure, a hundred years old, and an amulet, a Liturgical Prayerbook, (7) a ruling template, and a Book of Refrains. There are devotions in the Refrains and a collection of the Blessed (8) Oblation when we set up the 
mandi. We make the taryāna, (9) and I read the collection and the banner hymns. Unfortunately, (10) your letter came to us when I was in Halfaya, my brother (11) having died, and I left afterwards. My dear Klila, I swear by the House of Life (12) that I did not know it. (13) I came on Sunday to Baghdad, (14) the first day of the Mandaean month, which we celebrate on the eighth day of (15) the month of July, and I delivered the library [to] the Justice Inspector, (16) Mr Drower. (17) He was not at his office, and I had left Baghdad when (18) your letter came. As a result, you are saying, 'I will examine the book with my eye'. (19) Dear Klila, I am not a liar, you say, 'I'll give 100 rupees', (20) and I'll be poor from it, and I truly love you, sister of the House of Life. (21) The library cost me 180 rupees. (22) From Qurna, W.Sh. Kumayt Rām bar Yasmīn.

\section{Commentary}

This is an undated letter from the personal correspondence of Stefana Drower (1879-1972) appearing here courtesy of Jorunn J. Buckley. The author of the letter is Sh. Kumayt Rām bar Yasminn, a priest of the Mandowi family who was then resident in the city of al-'Amāra, roughly $340 \mathrm{~km}$ southeast of Baghdad. The letter details the purchase of the Drower Collection manuscripts 13, 14, and 22 (herein described as 'the Treasure'), which are presently in the Bodleian Library, Oxford. The letter is written in a form of colloquial Arabic similar to the Iraqi standard, but with a few unexpected features, such as the use of the personal pronoun 'ana instead of 'āni. Its orthography shares some features with Mandaic, such as the elimination of the preposition $b$ - before 
the word bit 'house' and the spelling of final -i. Additionally, the author indiscriminately represents the vowels $i, \bar{o}$, and $\bar{e}$ with the letter o, which possibly reflects the phenomenon of 'imāla or raising, as this sound is often realized as a mid front $[\varepsilon]$ in the received pronunciation of Mandaic in Iraq, corresponding to the articulation of historical /a/ (fatha) in the gelet Arabic dialects. In the transcription below, I have normalised the Mandaic words to conform to Arabic orthography, to reflect the traditional Iraqi pronunciation of Mandaic and to minimise potential confusion between the two systems.

Line 1

asūta nihwilik. The first few lines consist of Classical Mandaic formulae. These particular formulae are employed to open many compositions, particularly letters. The verb is a base stem imperfective from the root $h-w^{-w} /{ }_{y}$, in the 3ms form, with a 3ms enclitic indirect object, literally meaning 'may it (health) be for you'.

\section{Line 2}

mšabba māri $b$-libbi dakya. The first word is a passive participle from the causative stem of the verb $\sqrt{s}-b_{-}{ }^{w} / y$ 'to praise'.

Line 3

Makkī yusallim 'alēk yabūs 'ìdeek. Sh. Kumayt refers here to his son, the famous Iraqi actor Makkī Al-Badrī (16/6/19255/8/2014), whom Drower first met when he was still a small child. 


\section{Line 4}

klīla šišyān asūta nihwilkkun. The salutation returns to Mandaic, using the same standard formula found in $\ln .1$, albeit with the 2pl suffix ('may there be health for [all of] you'). Klila 'crown' is the Mandaic equivalent of Drower's given name, Stefana; Šǐšyān is the Mandaic form of her mother's name.

\section{Lines 4-5}

maktūbič jā w-ana mamnūn. It is in the second of these lines that we find the first colloquial features of this text, namely the form of the $2 \mathrm{fs}$ possessive suffix -ič instead of the more standard $-k i$. Also noteworthy in this context is the apparent lenition of the glottal stop in jā 'it came' $\left(<j \bar{a}^{\prime} a\right)$ and $w$-ana 'and I' ( $\left.<w a-{ }^{\prime} a n a\right)$. Lines 5-7

jäbit Ginza kabira 'atiqa tarĭh miyyat sinna wa-zrazta wa-Qlasta watașțir șbāga $w$-'Anyāni. Here one encounters the colloquial verb $j \bar{a} b \sim y j i \bar{b}$ 'to bring' together with the names of some well-known Mandaic compositions, the Ginza Rabba or Great Treasure, and the Qulasta and Inyāni, which were published together as the $\mathrm{Ca}$ nonical Prayerbook of the Mandaeans (Drower 1959). The hundred-year-old Treasure mentioned here was likely accessioned into the Drower Collection as DC 22, which is dated to 1831 and was purchased by Drower in 1936 (Buckley 2010, 106-7). The words taștir [sic] șbāga (تسطير صباغة) refer to the template used when ruling manuscript pages to ensure that the writing follows straight lines, a photo of which appears in Buckley (2010, Plate 8). 


\section{Lines 7-8}

b-Anyānī rahmī wa-majmū'a Zidqa Brīha min nițras 'il-manda, nsawwī țaryāna. The Blessed Oblation (Zidqa Briha) is a ritual performed on certain occasions, in this instance for the consecration of the mandi, the structure which is the site of many Mandaean rituals, and the making of the taryāna, the clay table on which the ritual is performed. The use of min 'at the time' is another colloquial feature of this text. The verb derived from $v t$-r-s (often $\checkmark t-r-s)$ 'to consecrate' derives from Mandaic and is particular to the Mandaean ritual vocabulary.

Lines 8-9

w-ana qrā 'il-majmū'a w-anyāni darafša. The word daraf̌̌a or darfaš refers to the ritual banner employed during baptism, consisting of a length of white silk wrapped around a wooden crosspiece. Banner hymns (cf. Drower 1959, 330-47) are recited during the ritual of erecting, unfurling, and dismantling this banner in the Jordan.

\section{Lines 9-11}

ma'a-l-asaf maktūbič jāna w-ana b-il-Halfaya w-ana hū̄yya māt watallit 'ahar. Halfaya is a plateau $35 \mathrm{~km}$ southeast of al-'Amāra. The colloquial form hūyya 'my brother' appears here in place of the standard 'ahi. The colloquial form tallit replaces standard tal'it, in which the ' has assimilated to the preceding $l$.

Lines 11-12

'azizti klila w-a'ad Bit Hayya m-alam bih. The House of Life is a location within the 'lightworld', although it often stands metonymically for the latter. While one would expect the preposition 
$b$-, in Mandaic texts this preposition is regularly not written before the word bit.

Lines 12-14

jīt yōm il-aḥad 'al-Bağdād, yōm rās šahar il-mandāya, yōm tāmin bšahar ngarraz šahar Tammūz. The form ngarraz is evidently nuqarraz 'we celebrate, extol'. During the 24-year period in which Drower lived in Baghdad, the 8th of Tammūz (July) fell on a Sunday (yōm il-ahad) in 1923, 1928, 1934, and finally in 1945. The aforementioned Treasure (DC 22) was the subject of a letter from another priest, Sh. Negm, who wrote Drower on 2 February 1936 to inform her that it had arrived and that he would send it with the next mail. Therefore, it seems likely that this letter was composed in 1934. In that year, the date 8 July indeed corresponded to the first day of T⿱ābit / Gadyā, the twelfth month of the Mandaean calendar.

Lines 15-16

w-ana sallamit bèt il-ginzì li-mfattiš il-‘adl Mistar Drawar. The phrase bèt il-ginzì 'library', an Arabic calque on Mandaic bit ginzì, literally means 'house of the treasures' or 'treasury'. Edwin Drower, Stefana Drower's husband, served as the Inspector-General of the Iraqi Ministry of Justice from 1922 to 1946.

Lines 17-18

$m \bar{u}$ 'amaktab[a] w-ana țalliit Bağdād liman yajīni maktūbič. The first two words of this sentence appear to be $m^{\prime}{ }^{c} a$ maktūb, but this would be meaningless in this context. We know from context that Drower had not yet acquired the manuscript or paid for it. So they must mean something along the lines of 'he was not at his office'. For tallit, see $\ln .11$ above. 


\section{Line 18}

'ād 'intì tagūlīn 'ašawwif b-'ēnì li-ktāb. The conjunction 'ād 'but; therefore, as a result' is another colloquial feature, as is the voicing of $q$ in tagülìn 'you (f) say'.

Line 19

'aziztī klìla, 'ana mūšs kaddāb. The negative particle mūš is a colloquial feature, as is the plosivisation of the fricative $\underline{d}$ in kaddāb.

Lines 19-20

tagūlin 'āt miyyat rūbiyya $w$-ana minna faqìr $w$-a $a^{n a}$ hibannič taranī hayat Bït Hayya. Drower glosses the verb 'āt as 'I will give', probably reflecting standard Arabic ' $u^{c a} t$; in its place, one would expect 'anti. If this is indeed the meaning, it is conjugated as if it came from a hollow root. The form 'ahibannič, standard Arabic 'uhibu-ki, is less problematic, save for the anomalous - $n$ - before the object suffix. This may reflect an energic form. The colloquial form hayat 'sister' appears here in place of standard 'uht. For Bit Hayya, see $\ln .11$ above.

\section{Line 21}

bēt l-ginzī șār 'alèya b-miyya $w$-tamānīn rūbiyya. For bēt l-ginzī, see In. 15 above. As with the word sor, inti, Sh. Kumayt sometimes indicates final $-i$ by means of the letters $s$, a device borrowed from Mandaic orthography.

\section{Line 22}

min qurna, wali šieh Kmèt Rām bar Yasmīn.

Sh. Kumayt closes his letter with a few words that have presented particular difficulties for its readers, including native speakers of Iraqi Arabic. The location from which ( $\mathrm{min}$ ) Sh. Kumayt writes is evidently Qurna, a town roughly $100 \mathrm{~km}$ due south of al-'Amāra 
and $74 \mathrm{~km}$ northwest of Basra, but he has written this word with the letter \& (qirna) rather than the expected s (*qurna). The spelling of his title, šieh (for standard Arabic šayh 'old man; sheikh') reflects the monophthongization of the historical diphthong and its subsequent division into two segments, which is characteristic of colloquial Arabic in this region. Between the two words is the word wali 'guardian; authorized agent', which possibly refers to Sh. Kumayt's role in securing these documents on Drower's behalf. 



\title{
36. AN ANECDOTE ABOUT JUḤĀ (1920S)
}

\author{
Tania María García-Arévalo
}

Unknown author. Printed by Maklūf Najar in Sousse, Tunisia, first half of the 20th century.

\section{Transcription}

ג'חא וברמת אללחם

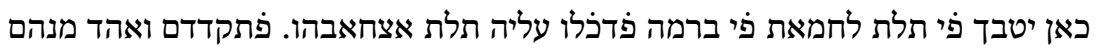

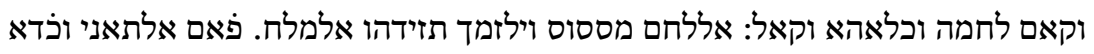

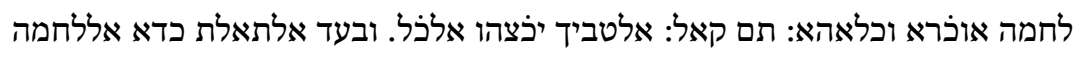

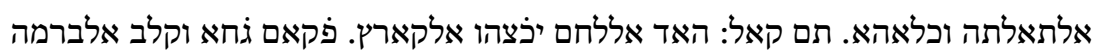

פי אלקאעה וקאל: האד אלברמה יכצצהא אללחם!

\section{Arabic Transcription}

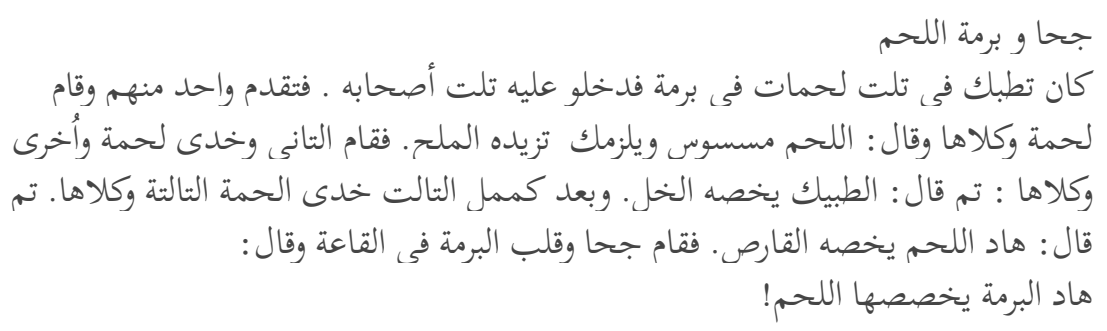




\section{Translation}

Juhā and the meat pot

While he was cooking three pieces of meat, three of his friends came in. One of them came forward, picked up a piece of meat, ate it, and said: "The meat is bland and you have to add salt." The second got up and took another piece of meat and ate it. Then he said: "The cook was short on vinegar." Finally, the third took the third piece of meat and ate it. Then he said: "This meat lacks heat." Juhā stood up, turned the pot over on the ground, and said: "This pot is missing the meat!"

\section{Commentary}

One of the most relevant issues in Judaeo-Arabic literature in its modern and contemporary period is its spelling. In the case of North Africa, the phonetic principle of how to transcribe Arabic divides the area into two groups. The orthography of the first group, consisting of Libya, Tunisia, and eastern Algeria, closely followed Classical Judaeo-Arabic norms, differing from the orthography characteristic of the second group, comprising Oran, Morocco, and western Algeria, which was further removed (Tobi, 2014, 142). The text presented here is, in fact, a faithful reflection of the evolved Arabised orthography produced in modern Tunisia.

General features that both groups exhibit are the reduplication of consonants to represent medial, but never final, šadda (gemination), as well as 'alef to represent the different types of 'alif (maqșūra, mamdūda, wașla) without any distinction between 
them. Also, 'alif is used to represent the morphophonemic definite article al-, without any changes before 'sun' or 'moon' letters. As in most Judaeo-Arabic texts, the interdentals are lost in favour of dentals, corresponding to Jewish dialects in Tunisia, which in their oral variety have lost this feature, too.

The verbal system of modern Tunisian Judaeo-Arabic does not differ dramatically of that of Classical Arabic. The main divergences can be found in the phonetic rules applied to the conjugations and in the use of afformatives and preformatives. We find a similar situation in nominal morphology, where nominal patterns do not vary from Classical Arabic, and the changes are restricted to vocalisation due to the impossibility of short vowels in open syllables. 



\section{REFERENCES}

'Abd al-Rahị̄m, 'Abd al-Rahīm 'Abd al-Raḥmān (ed.). 1989. Kitāb al-durra al-mușāna fì 'ahbār al-Kināna fi 'ahbār mā waqa'a bi-Mișr fi dawlat al-Mamālìk min al-sanāğiq wa-al-kuššāf waal-sab'at 'ūğāqāt wa-al-dawla wa-'awāyidihim wa-al-bāš̄ 'ilā 'āhir sanat țamānin wa-sittin wa-mi'a wa-'alf / Livre d'Aldurra al-muṣāna dans [sic] Ahbār ak-Kināna par Aḥmed Kathoda 'Azbān al-Demerdāšì. (Nuṣūụ 'arabiyya wa-dirāsāt 'islāmiyya / Textes arabes et études islamiques 28. Cairo: Al-ma'had al 'ilmī al-firansī li-l-'ātāâr al-šarqiyya bi-l-Qāhira / Institut français d'Archéologie orientale du Caire.

'Ag̀lū, Sinān Ma'rūf. 2002. Najd wa-l-Hijāz fi l-wațā'iq al'uțmāniyya: Al-'ahwwāl al-siyāsiyya wa-l-ijtimā'iyya fi Najd wal-Hijāz hilāl al-'ahd al-'uțmānì. Beirut: Dār al-Sāqī.

Aguadé, J. 2018. 'The Maghrebi dialects of Arabic'. In Arabic Historical Dialectology: Linguistic and Sociolinguistic Approaches, edited by Clive Holes, 29-64. Oxford: Oxford University Press.

Al-Sanhūrī, Muhammad ibn Mahfūẓ. 2016. Risible Rhymes, or The Book to Bring a Smile to the Lips of Devotees of Proper Taste and Style through the Decoding of a Sampling of the Verse of the Rural Rank and File (Kitāb Muḍhik dhawì l-dhawq wa-lnizām fì hall shadharah min kalām ahl al-rïf al-'awāmm). Library of Arabic Literature. New York: New York University Press. 
Arad, Dotan. 2016. “"A Pleasant Voice and an Expert on Every Matter": On Karaite and Rabbanite Cantors in 16th-century Egypt'. Ginzei Qedem 12: 147-69. [Hebrew]

Arberry, Arthur J. 1963. The Koran Interpreted. 2nd imprint. London: George Allen \& Unwin.

Avallone, Lucia. 2016. 'Spelling Variants in Written Egyptian Arabic: A Study on Literary Texts'. In Arabic Varieties: Far and Wide-Proceedings of the 11th International Conference of AIDA, Bucharest, 2015, edited by George Grigore and Gabriel Biţună, 79-86. Bucharest: Bucharest University Press. Avishur, Yitshak. 1992. 'New Folk Tales about Abraham b. 'Ezra (and his Sons) from Egypt and Iraq'. In Studies in the Works of Abraham b. 'Ezra, edited by Israel Levin and Mashah Itzhaki, 163-92. Tel-Aviv: Tel-Aviv University Press. [Hebrew]

Ayoun, Richard. 'Bush'ara (Bouchara) Family'. In Encyclopedia of Jews in the Islamic World, edited by Norman Stillman (Brill: Leiden, 2010), https://referenceworks.brillonline.com/entries/encyclopedia-of-jews-in-the-islamic-world/busharabouchara-family-SIM_0004720.

Badawi, El-Said, and Martin Hinds. 1986. A Dictionary of Egyptian Arabic: Arabic-English. Beirut: Librairie du Liban.

Barthélemy, Adrien. 1935-1969. Dictionnaire Arabe-Français, Dialectes de Syrie: Alep, Damas, Liban, Jérusalem. Paris: P. Geuthner. 
Basset, R. 2012. 'Ka'b b. Zuhayr'. In Encyclopaedia of Islam, 2nd edition, edited by P. Bearman, Th. Bianquis, C. E. Bosworth, E. van Donzel, W. P. Heinrichs. http://dx.doi.org/ 10.1163/1573-3912_islam_SIM_3733

Behnstedt, Peter. 1987. Die Dialekte der Gegend von Șa'dah (NordJemen). Wiesbaden: Harrassowitz.

Bellem, Alex, and G. Rex Smith. 2014. 'Middle Arabic? MorphoSyntactic Features of Clashing Grammars in a ThirteenthCentury Arabian Text'. In Languages of Southern Arabia, edited by Orhan Elmasz and Janet C. E. Watson, 9-19. Supplement to the Proceedings of the Seminar for Arabian Studies 44. Oxford: Archaeopress.

de Biberstein-Kazimirski, Albert. 1860. Dictionnaire Arabe-Français. 2 vols. Paris: Maisonneuve.

Blanc, Haim. 1985. 'Egyptian Judeo-Arabic: More on the Subject of R. Mordekhai b. Yehuda Ha-Levi's Sefer Darkhe No'am'. Sefunot n.s. 3/18: 299-314. [Hebrew]

Blau, Joshua. (1965) 1999. The Emergence and Linguistic Background of Judaeo-Arabic. Jerusalem: Yad Izhak Ben-Zvi.

- 2002. A Handbook of Early Middle Arabic. Jerusalem: The Max Schloessinger Memorial Foundation and The Hebrew University of Jerusalem.

—. 2006. A Dictionary of Judaeo-Arabic Texts. Jerusalem: The Academy of the Hebrew Language.

Borbone, Pier Giorgio. 2015. 'Syro-Mongolian Greetings for the King of France: A Note About the Letter of Hülegü to King Louis IX (1262)'. Studi Classici e Orientali 61: 479-84. 
Boris, Gilbert. 1958. Lexique du parler arabe des Marazig. Études arabes et islamiques, Études et documents I. Paris: Imprimerie Nationale and Librairie Klincksieck.

Bosworth, Clifford Edmund. 1976. The Mediaeval Islamic Underworld. Leiden: Brill.

Buckley, Jorunn J. 2010. The Great Stem of Souls: Reconstructing Mandaean History. Piscataway, NJ: Gorgias.

al-Bustānī, 'Abdallah. 1930. Al-Bustān wa-huwa mu'jam lughawī. Beirut: American Press.

al-Bustānī, Fu'ād, and 'Asad Rustum (eds). 1969. Al-Ṣafadī, 'Aḥmad b. Muḥammad al-Hुālidī [d. 1625], Lubnān fì 'ahd al-'amìr Fahr al-Dìn al-Ma'nì al-țānì [1572-1635]. Beirut: Publications de l'Université Libanaise, Section des Études historiques XVI.

Cantineau, Jean. 1960. 'Études de linguistique arabe: Mémorial Jean Cantineau'. Études arabes et islamiques: Études et documents II. Paris: C. Klincksieck.

Carter, Michael G. 1998. 'Ibn Ājurrūm'. In Encyclopedia of Arabic Literature, edited by P. Starkey and J. Meisami, I: 308-9. London and New York: Routledge.

Cezzâr, Ahmed. 1962. Ottoman Egypt in the Eighteenth Century: The Nizâmnâme-i Misisir of Cezzâr Aḥmed Pasha. Edited and translated from the original Turkish by Stanford J. Shaw. Cambridge, MA: Harvard University Press.

Connolly, Magdalen M. 2018. 'A Nineteenth-century CE Egyptian Judaeo-Arabic Folk Narrative: Text, Translation and Grammatical Notes'. In Studies in Semitic Linguistics and Manu- 
scripts, edited by Nadia Vidro, Ronny Vollandt, Esther-Miriam Wagner, and Judith Olszowy-Schlanger, 392-420. Studia Semitica Upsaliensia 30. Uppsala: University of Uppsala.

. 2019. 'Revisiting the Question of Ğìm from the Perspective of Judaeo-Arabic'. Journal of Semitic Studies 64/1: 15583.

- 2021. 'Splitting Definitives: The Separation of the Definite Article in Medieval and Pre-Modern Written Judeo-Arabic'. Journal of Jewish Languages 9: 32-76.

- Forthcoming. Judaeo-Arabic Folk Tales and Letters from the Pre-Modern Period: A Study in Linguistic Variation. Études sur le judaïsme medieval. Leiden: Brill.

Corriente, Federico. 1977. A Grammatical Sketch of the Spanish Dialect Bundle. Madrid: Instituto Hispano-Árabe de Cultura, Dirección General de Relaciónes Culturales.

— 1997. A Dictionary of Andalusi Arabic. Leiden: Brill.

Crecelius, Daniel, and 'Abd al-Wahhab Bakr (eds). 1991. Al-Damurdāšì's Chronicle of Egypt, 1688-1751. Leiden: Brill.

Crum, Walter Ewing. 1939. A Coptic Dictionary. Oxford: Clarendon Press.

Davies, Humphrey Taman. 1981. 'Seventeenth-century Egyptian Arabic: A Profile of the Colloquial Material in Yūsuf alŠirbīnī's Hazz al-Quhūf fỉ Šarh Qașīd 'Abī Šādūf'. PhD dissertation, University of California, Berkeley. . (ed.). 2016. Yūsuf al-Shirbīnī's Brains Confounded by the Ode of Abū Shādūf Expounded (Hazz al-quhūf bi-sharh qaṣid 
Abi Shādūf). 2 vols., translated by Humphrey Davies. Library of Arabic Literature. New York: New York University Press.

Davis, S. 1995. 'Emphasis Spread in Arabic and Grounded Phonology'. Linguistic Inquiry 26/3: 465-98.

—_ 2011. 'Velarization'. In Encyclopedia of Arabic Language and Linguistics, edited by Kees Versteegh et al., IV: 636-38. Leiden: Brill.

Den Heijer, Johannes. 2012. 'Introduction'. In Middle Arabic and Mixed Arabic: Diachrony and synchrony, edited by Liesbeth Zack and Arie Schippers, 1-25. Leiden: Brill.

Diem, Werner. 2014. 'Ägyptisch-Arabisch im 17. Jahrhundert. Die arabischen Zeugenaussagen in Mordechai ha-Levis Sefer Darke No'am (Venedig 1697)'. Mediterranean Language Review 21: 1-89.

Dinno, K. 2017. The Syrian Orthodox Christians in the Late Ottoman Period and Beyond: Crises then Revival. Piscataway, NJ: Gorgias Press.

Dolabani, Y. 1990. orthodoxen Kirche von Antiochien. Glane and Losser: Bar-Hebraeus Verlag. [Syriac]

Doss, Madiha. 1998. 'Dialecte égyptien et questions de langue au XIX ${ }^{\mathrm{e}}$ siècle: Le case de 'Abd Allāh Nadīm'. MAS-GELLAS nouvelle série 8: 143-70.

Dozy, R. P. A. 1845. Dictionnaire détaillé des noms des vêtements chez les Arabes: Ouvrage couronné et publié par la troisieme classe de l'Institut Royal des Pays-Bas. Amsterdam: J. Müller. 
- 1881. Supplément aux dictionnaires arabes. 2 vols. Leiden: Brill.

Drower, E. Stefana. 1959. The Canonical Prayerbook of the Mandaeans. Leiden: Brill.

El-Tantavy, Mouhammad Ayyad. 1848. Traité de la langue arabe vulgaire = Ahsan al-nuxab fì ma'rifat lisān al-'arab. Leipzig: Guillaume Vogel Fils.

Farah, Caesar E. 2002. The Sultan's Yemen: Nineteenth-Century Challenges to Ottoman Rule. London and New York: I. B. Tauris.

al-Fīrūzābādī, Majd al-Dīn Muhammad b. Yađqūb. 1999. AlQāmūs al-muhịt.t. țab`a jadìda wa muwațtaqa wa muṣaḥhaha. Cairo: Dār al-Fikr li-1-Ṭibā'a wa-1-Našr wa-l-Tawzīc .

Florence, Ronald. 2004. Blood Libel: The Damascus Affair of 1840. Madison: University of Wisconsin Press.

Forshall, Josiah, and Friedrich, Rosen. 1838. Catalogus codicum manuscriptorum orientalium qui in Museo Britannico asservantur: 1 Codices Syriacos et Carshunicos amplectens. London: British Museum.

Frankel, Jonathan. 1997. "Ritual Murder" in the Modern Era: The Damascus Affair of 1840'. Jewish Social Studies 3/2: 1 . Friedman, Mordechai Akiva. 2016. A Dictionary of Medieval Judaeo-Arabic. Jerusalem: Ben Zvi Institute.

Gairdner, W. H. R. 1917. Egyptian Colloquial Arabic: A Conversation Grammar and Reader. Cambridge: W. Heffer \& Sons.

Gendzier, Irene L. 1966. The Practical Visions of Ya'qub Sanu`. Cambridge, MA: Harvard University Press. 
al-Ghazzī, Najm al-Dīn Muḥammad ibn Muḥammad. 1958. AlKawākib al-sā’ira bi-a' yān al-mi'a al-'āshira. Beirut: American University of Beirut.

Goitein, S. D. 1941. Travels in Yemen: An Account of Joseph Halévy's Journey to Najran in the Year 1870 Written in San'ani Arabic by his Guide Hayym Habshush. Jerusalem: The Hebrew University Press.

—_ 1972. 'Townsman and Fellah: A Geniza Text from the Seventeenth Century'. Asian and African Studies 8: 257-61. Hacker, Joseph. 2015. 'Jewish Book Owners and Their Libraries in the Iberian Peninsula, Fourteenth-Fifteenth Centuries'. In The Late Medieval Hebrew Book in the Western Mediterranean: Hebrew Manuscripts and Incunabula in Context, edited by Javier del Barco, 70-104. Leiden: Brill.

al-Hamdānī, Al-Ḥasan b. 'Aḥmad. 1884-1891. Sifat Ğazirat al'Arab, edited by D. H. Müller. Leiden: Brill.

Hanna, Nelly. 1998. 'Culture in Ottoman Egypt'. The Cambridge History of Egypt, edited by M. W. Daly, II: 87-112. Cambridge: Cambridge University Press.

Hary, Benjamin. 1987. 'Judeo-Arabic, Written and Spoken in Egypt in the Sixteenth and Seventeenth Centuries'. PhD dissertation, University of California, Berkeley.

- 1992. Multiglossia in Judeo-Arabic, with an Edition, Translation, and Grammatical Study of the Cairene Purim Scroll. Leiden: Brill.

. 1996. 'Adaptations of Hebrew Script'. In The World's Writing Systems, edited by W. Bright and P. Daniels, 727-34, 741-42. Oxford: Oxford University Press. 
- 2009. Translating Religion: Linguistic Analysis of Judeo-Arabic Sacred Texts from Egypt. Leiden and Boston: Brill.

__ 2017. 'Spoken Late Egyptian Judeo-Arabic as Reflected in Written Forms'. Jerusalem Studies in Arabic and Islam 44: $11-36$.

Hassan, Anton. 1869. Kurzgefasste Grammatik der vulgär-arabischen Sprache mit besonderer Berucksichtigung auf den egyptischen Dialekt. Vienna: K.K. Hof- und Staatsdruckerei.

Hava, J. G. 1899. Arabic-English Dictionary for the Use of Students. Beirut: Catholic press.

Havlin, Shlomo Zalman (ed). 1995. History of the Oral Law and of Early Rabbinic Scholarship by Rabbi Menahem ha-Meiri. Jerusalem/Cleveland: Ofeq Institute. [Hebrew]

Healey, John F. 2005. Leshono Suryoyo: First Studies in Syriac. Piscataway, NJ: Gorgias Press.

Heidelberg University. n.d. Abou Naddara Collection: Introduction: Journals. http://kjc-sv036.kjc.uni-heidelberg.de:8080/exist/apps/naddara/index.html

Heidelberg University. n.d. James Sanua: Biography. http://kjcsv036.kjc.uni-heidelberg.de:8080/exist/apps/naddara/biography.html

Hinds, Martin, and el-Said Badawi. 1986. A Dictionary of Egyptian Arabic: Arabic-English. Beirut: Librarie du Liban.

Hoffman, A., and P. Cole. 2011. Sacred Trash: The Lost and Found World of the Cairo Geniza. New York: Nextbook and Schocken Books. 
Holes, Clive. 2019. 'Confessional Varieties'. In Handbook of Arabic Sociolinguistics, edited by Enam Al-Wer and Uri Horesh, 63-80. London: Routledge.

Ibrāhīm, 'Abd Allāh 'Alī (ed.). 1983. Wațā'iq 'an ta'rīh Lỉbiyā fì lqarn al-tāsi'‘ašar. Al-juz' al-'awwal, țawrat Ġūmat alMaḥmūdī 1835-1858. Tripolis (Libya): Markaz dirāsāt jihād al-Lìbiyyīn ḍidd al-ġazw al-'īṭālī.

'İsā, Razzūq. 2016. Reprint of Al-Manhūt al-'āmmì wa-l-lufz aldaǩil fi lugat Bag்dād (originally in Majalla lugiat al-'arab 1911, issue 6, p. 255) in Bag்dād fi lugiat al-`arab, Part III, p. 136. Karbalā'.

Jastrow, Marcus. (1903) 2005. A Dictionary of the Targumim, the Talmud Babli and Yerushalmi, and the Midrashic Literature. Peabody, MA: Hendrickson.

Kallas, Elie. 2012. 'The Aleppo Dialect According to the Travel Accounts of Ibn Racd (1656) Ms. Sbath 89 and Hanna Dyāb (1764) Ms. Sbath 254'. In De los manuscritos medievales a internet: La presencia del árabe vernáculo en las fuentes escritas, edited by Mohamed Meouak et al., 221-52. Zaragoza: Universidad de Zaragoza, Área de Estudios Arabes e Islámicos.

de Kazimirski, A. 1860. Dictionnaire arabe-francais contenant toutes les racines de la langue arabe: Leurs derives, tant dans l'idiome vulgaire que dans l'idiome litteral, ainsi que les dialectes d'Alger et de Maroc. Paris: Maisonneuve.

Khan, Geoffrey. 1991. 'A Study of the Judaeo-Arabic of Late Genizah Documents and Its Comparison with Classical Judaeo-Arabic'. Sefunot n.s. 5/20: 223-24. 
- 1992. 'Notes on the Grammar of a Late Judaeo-Arabic Text'. Jerusalem Studies in Arabic and Islam 15: 220-39.

_. 2006. 'A Judaeo-Arabic Commercial Letter from Early Nineteenth-Century Egypt'. Ginzei Qedem 2: 37-59.

- 2007. 'Judaeo-Arabic'. In Encyclopedia of Arabic Language and Linguistics, edited by Kees Versteegh et al., II: 526-36. Leiden: Brill.

—. 2010. 'Vocalised Judaeo-Arabic Manuscripts in the Cairo Genizah'. In 'From a Sacred Source': Genizah Studies in Honour of Stefan C. Reif, edited by B. Outhwaite and S. Bhayro, 201-18. Leiden and Boston: Brill.

—. 2018. 'Judaeo-Arabic'. In Arabic Historical Dialectology: Linguistic and Sociolinguistic Approaches, edited by Clive Holes, 148-70. Oxford: Oxford University Press.

Kīlānī, Muḥammad. 1965. Al-Adab al-Miṣrī fī ẓill al-ḥukm al-‘uthmani. Cairo: Dār al-Qawmiyya al-'Arabiyya.

de Landberg, Comte. 1901. Etudes sur les dialectes de l'Arabie méridionale, i, Haḍramoût. Leiden: Brill.

—. 1920-1942. Glossaire dațînois. 3 vols. Leiden: Brill.

Lane, Edward William. 1863-1893. An Arabic-English Lexicon, Derived from the Best and the Most Copious Eastern Sources. Edited by Stanley Lane-Poole. London: Williams and Norgate. Larkin, Margaret. 2006. 'Popular Poetry in the Post-Classical Period'. In Arabic Literature in the Post-Classical Period, edited by Roger Allen and D. S. Richards. Cambridge: Cambridge University Press. 
Lentin, Jérôme. 1997. 'Recherches sur l'histoire de la langue arabe au Proche-Orient à l'époque moderne'. PhD dissertation, University of Paris III.

__ 2008. 'Middle Arabic'. In Encyclopedia of Arabic Language and Linguistics, edited by Kees Versteegh et al., III: 215-24. Leiden: Brill.

. 2011. 'Middle Arabic'. In Encyclopedia of Arabic Language and Linguistics Online Edition, edited by Lutz Edzard, Rudolf de Jong. $\quad \underline{\text { http://dx.doi.org/10.1163/1570- }}$ 6699_eall_EALL_COM_vol3_0213

. 2012. 'Normes orthographiques en moyen arabe: Sur la notation du vocalisme bref'. In Middle Arabic and Mixed Arabic: Diachrony and Synchrony, edited by Liesbeth Zack and Arie Schippers, 209-34. Studies in Semitic Languages and Linguistics 64. Leiden: Brill.

Marchand, Trevor (ed.). 2017. Architectural Heritage of Yemen: Buildings that Fill my Eye. Berkeley, CA: Gingko Library.

Marçais, William, and Abderrahmân Guîga. 1958-1961. Textes arabes de Takroûna II. Glossaire: Contribution à l'étude du vocabulaire arabe, tomes I-VIII, Paris: Imprimerie Nationale, CNRS, and P. Geuthner.

Margoliouth, G. 1899. Descriptive List of Syriac and Karshuni MSS. in the British Museum Acquired since 1873. London: British Museum.

Masters, Bruce Alan. 2001. Christians and Jews in the Ottoman Arab World: The Roots of Sectarianism. Cambridge Studies in Islamic Civilization. Cambridge; New York: Cambridge University Press. 
Matthee, R. 2012. 'Tutun'. In Encyclopaedia of Islam, 2nd edition, edited by P. Bearman, Th. Bianquis, C. E. Bosworth, E. van Donzel, W. P. Heinrichs. http://dx.doi.org/10.1163/15733912_islam_COM_1266.

McCollum, Adam Carter. 2014. 'Garshuni as It Is: Some Observations from Reading East and West Syriac Manuscripts'. Hugoye: Journal of Syriac Studies 17/2: 215-35.

Mittwoch, Eugen. 1926. Aus dem Jemen: Hermann Burchardts letze Reise durch Südarbien. Leipzig: Deutsche Morgenländische Gesellschaft, in Kommission bei F. A. Brockhaus.

al-Nadīm, 'Abd Allāh. (1892-1893) 1994. Al-A'dād al-ḥāmila limajallat al-Ustād. 2 vols. Cairo: Al-Hay’a al-Miṣriyya al'Āmma li-1-Kitāb.

Nahem, Ilan. 1996. The "Metzah Aharon" Commentary on the Pentateuch by Rabbi Aharon Garish. Jerusalem: Ben Zvi Institute. [Hebrew]

Naïm, Samia. 2009. L'Arabe yéménite de Sanaa. Leuven and Paris: Peeters.

Nizami, K. A. 'Faḳīr'. In Encyclopaedia of Islam, 2nd edition, edited by P. Bearman, Th. Bianquis, C. E. Bosworth, E. van Donzel, W. P. Heinrichs. http://dx.doi.org/10.1163/15733912_islam_SIM_2252.

Nu'aysa, Yūsuf. 1988. Ibn al-Ṣiddīq, Ġarā'ib al-badā'i` wa- 'ajā’’ib al-waqā'ic': Al-ḥayāt al-'arabiyya fì l-qarn al-țāmin 'ašar almìlādì. Damascus: Dār al-ma'rifa.

Palva, Heikki. 1993. 'Hikāya fī damm al-nisā', a Story in Dispraise of Women: A 14th-century (?) Egyptian Judaeo-Arabic Manuscript'. In The Middle East: Unity and Diversity- 
Papers from the Second Nordic Conference on Middle Eastern Studies, Copenhagen 22-25 October 1992, edited by Heikki Palva and Knut S. Vikør, 176-88. Copenhagen: Nordic Institute of Asian Studies.

Pamuk, Sevket. 2000. A Monetary History of the Ottoman Empire. New York: Cambridge University Press.

Pellat, Ch. 2012a. 'Ibn Shuhayd'. In Encyclopaedia of Islam, 2nd edition, edited by P. Bearman, Th. Bianquis, C. E. Bosworth, E. van Donzel, W. P. Heinrichs. http://dx.doi.org/10.1163/1573-3912_islam_SIM_3379.

. 2012b. 'Laḥn al-'Āmma'. In Encyclopaedia of Islam, 2nd edition, edited by P. Bearman, Th. Bianquis, C. E. Bosworth, E. van Donzel, W. P. Heinrichs. http://dx.doi.org/10.1163/1573-3912_islam_SIM_4613.

Piamenta, Moshe. 1990-1991. Dictionary of Post-classical Yemeni Arabic. 2 vols. Leiden: Brill.

Porter, Venetia. 1992. 'The History and Monuments of the Tahirid Dynasty of the Yemen, 858-923/1454-1517'. PhD dissertation, University of Durham.

. 2017. 'The Bani Tahir and the 'Amiriyya Madrasa: Architecture and Politics'. In Architectural Heritage of Yemen: Buildings That Fill My Eye, edited by Trevor Marchand, 5159. Berkeley, CA: Gingko Library.

Qafisheh, Hamdi A. 2000. Yemeni Arabic Dictionary. Chicago: NTC.

al-Radi, S. 1997. The Amiriya in Rada: The History and Restoration of a Sixteenth-Century Madrasa in the Yemen. Oxford Studies in Islamic Art 13. Oxford: Oxford University Press for the 
Board of the Faculty of Oriental Studies, University of Oxford.

Redhouse, James W. 1890. A Turkish and English Lexicon. Constantinople: Printed for the American Mission by A. H. Boyajian.

Reif, Stefan C., 2000. A Jewish Archive from Old Cairo: The History of Cambridge University's Genizah Collection. Richmond, Surrey: Curzon.

Rosenbaum, Gabriel. 2002. 'Spoken Jewish Arabic in Modern Egypt: Hebrew and Non-Standard Components'. Massorot 12: 117-48. [Hebrew]

Rossi, Ettore. 1939. L'Arabo Parlato a Șan' $\bar{a}^{\prime}$. Rome: Istituto per l'Oriente.

Russotto, Henry A. (ed. and trans.) 1912. Passover Hagadah with Music. New York: Hebrew Publishing Company.

Sadgrove, P. C. 2012. 'Al-Nadīm, al-Sayyid 'Abd Allāh'. In Encyclopaedia of Islam, 2nd edition, edited by P. Bearman, Th. Bianquis, C. E. Bosworth, E. van Donzel, W. P. Heinrichs. http://dx.doi.org/10.1163/1573-3912_islam_SIM_5713.

Șanū', Ya'qūb. 1878. Abū naḍdāara zarqāa’: Jarīdat musalliyyāt wamuḍhikāt. http://kjc-sv036.kjc.uni-heidelberg.de:8080/exist/apps/naddara/index.html\#.

Sells, Michael A. 1990. 'Bānat Su'ād: Translation and Introduction'. Journal of Arabic Literature 21/2: 140-54.

Serjeant, R. B., and Ronald Lewcock (eds). 1983. San' $(\bar{a}): A n$ Arabian Islamic City. London: World of Islam Festival Trust. 
al-Shami, Anas Muhammad, and Zakariyya Jabir Ahmad (eds). 2008. Al-Fayrūzabādī's Al-Qāmūs al-muhịṭ. Cairo: Dār alHadīth.

Smith, G. Rex. 1974-1978. The Ayyubids and Early Rasulids in the Yemen, 2 vols. E. J. W. Gibb Memorial Series, n. s. 26. London: Luzac \& Co.

- 1988. 'The Political History of the Islamic Yemen Down to the First Turkish Invasion (1-945/622-1538)'. In Yemen: 3000 Years of Art and Civilisation in Arabia Felix, edited by W. Daum, 129-39. Innsbruck: Umschau-Verlag.

- 2004. 'The Classical Arabic Pattern fa'āli Revisited'. In Biblical and Near Eastern Essays: Studies in Honour of Kevin J. Cathcart, edited by Carmel McCarthy and John F. Healey, 264-80. Journal for the Study of the Old Testament Supplement Series 375/The Library of Hebrew Bible/Old Testament Studies 375. London and New York: T\&T Clark.

Spiro, Socrates. 1895. An Arabic-English Vocabulary of the Colloquial Arabic of Egypt, Containing the Vernacular Idioms and Expressions, Slang Phrases, etc., etc., Used by the Native Egyptians. London: Bernard Quaritch.

Spitta, Wilhelm. 1880. Grammatik des arabischen Vulgärdialektes von Aegypten. Leipzig: J.C. Hinrichs.

Steingass, F. 1884. The Student's Arabic-English Dictionary. London: Crosby Lockwood.

—_ 1930. A Comprehensive Persian-English Dictionary. London: Kegan Paul, Trench, Trubner. 
Tobi, Y. 2014. 'Judaeo-Arabic Printing in North Africa, 18501950', in Historical Aspects of Printing and Publishing in Languages of the Middle East, edited by G. Roper, 129-150. Leiden: Brill.

al-'Usțā, Muhammad, and 'Ammār Juhaydar (eds). (1984) 2001. Hasan al-Faqīh Hasan's Al-yawmiyyāt al-libiyya. Silsilat Nuṣūṣ wa-wațā̄iq 1-7. Benghazi: Dār al-Kutub al-Wațanī.

'Usțuwānī, 'As'ad (ed). 1993. Al-'Usțuwānī, Muḥammad's Mašăhid wa-'ahdāt Dimašq fi muntaṣaf al-qarn al-tāsi' 'ašar (1256-1277 h. / 1840-61 m.). Damascus (?).

Wagner, Esther-Miriam. 2010. Linguistic Variety of Judaeo-Arabic in Letters from the Cairo Genizah. Leiden: Brill.

- 2014. 'Subordination in 15th- and 16th-century JudeoArabic'. Journal for Jewish Languages 2: 143-64.

. 2018. 'Birds of a Feather: Arabic Scribal Conventions in Christian and Jewish Arabic'. In Studies in Semitic Linguistics and Manuscripts: A Liber Discipulorum in Honour of Professor Geoffrey Khan, edited by Nadia Vidro, Ronny Vollandt, Esther-Miriam Wagner, and Judith Olszowy Schlanger, 37691. Studia Semitica Upsaliensia 30. Uppsala: Acta Universitatis Upsaliensis.

Wagner, Esther-Miriam, and Mohamad A. H. Ahmed. 2017. 'From Tuscany to Egypt: Eighteenth Century Arabic Letters in the Prize Paper Collections'. Journal of Semitic Studies 62/2: 389-412.

Watson, Janet C. E. 1993. A Syntax of Șan'ānì Arabic. Semitica viva 13. Wiesbaden: Harrassowitz. 
1999. 'The Directionality of Emphasis Spread in Arabic'. Linguistic Inquiry 30/2: 289-300.

- 2000. Wasf Șan' $\bar{a}^{\prime}$ : Texts in Șan'āni Arabic. Semitica viva 23. Wiesbaden: Harrassowitz.

. 2002. The Phonology and Morphology of Arabic. Oxford Linguistics; Phonology of the World's Languages. Oxford and New York: Oxford University Press.

___ 2009. 'Ṣan'ānī Arabic'. In Encyclopedia of Arabic Language and Linguistics, edited by Kees Versteegh, IV: 106-15. Leiden: Brill.

Wehr, Hans. 1994. A Dictionary of Modern Written Arabic (ArabicEnglish). 4th ed. New York: Spoken Language Services.

Woidich, Manfred. 2006. Das Kairenisch-Arabische: Eine Grammatik. Porta linguarum orientalium, n. s. 22 Wiesbaden: Harrassowitz.

Wright, William. 1870-1872. Catalogue of Syriac Manuscripts in the British Museum Acquired since the Year 1838. 2 vols. London: British Museum.

Yāqūt, al-Ḥamawī. 1979. Mư̆ğam al-buldān. 5 vols. Beirut: Dār Ṣādir.

Zack, Liesbeth. 2009. Egyptian Arabic in the Seventeenth Century: A Study and Edition of Yūsuf al-Mağribï's 'Daf' al-iṣr 'an kalām ahl Miṣr'. Utrecht: LOT.

. 2014. 'The Use of the Egyptian Dialect in the Satirical Newspaper Abu Naḍd̄ara Zar'a'. In Alf lahja wa lahja: Proceedings of the 9th Aida Conference, edited by O. Durand, A. D. Langone, and G. Mion, 465-78. Vienna: Lit Verlag. 
_ 2016. 'Nineteenth-century Cairo Arabic as Described by Qadrī and Nahla'. In Arabic Varieties: Far and Wide-Proceedings of the 11th International Conference of AIDA, Bucharest, 2015, edited by G. Grigore and G. Bițună, 557-67. Bucharest: University of Bucharest Press. 



\section{Cambridge Semitic \\ Languages and Cultures}

W

शु,

14

limets

38:

1

General Editor Geoffrey Khan

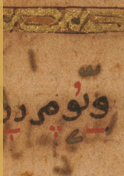

abe

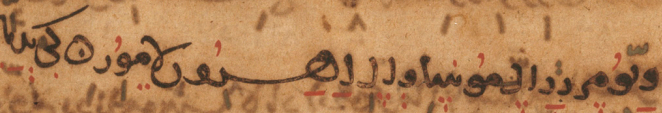

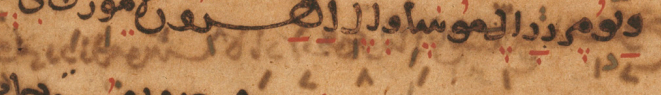

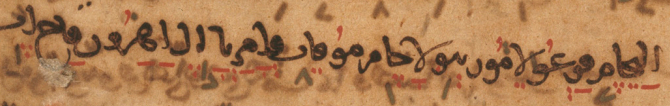

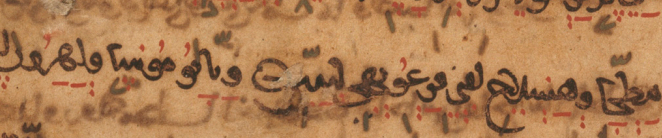

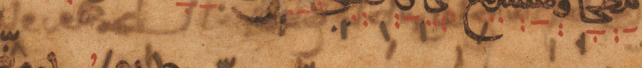

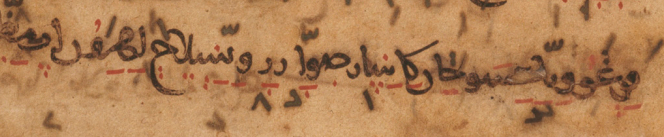

Lt 年 4

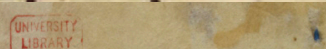

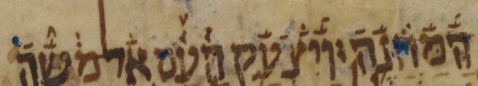

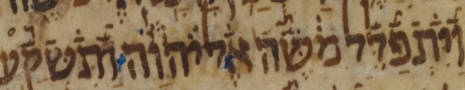

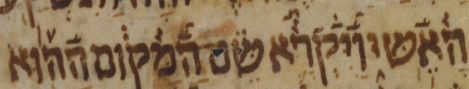

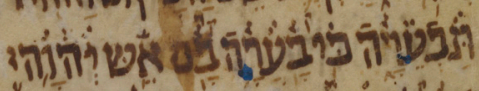

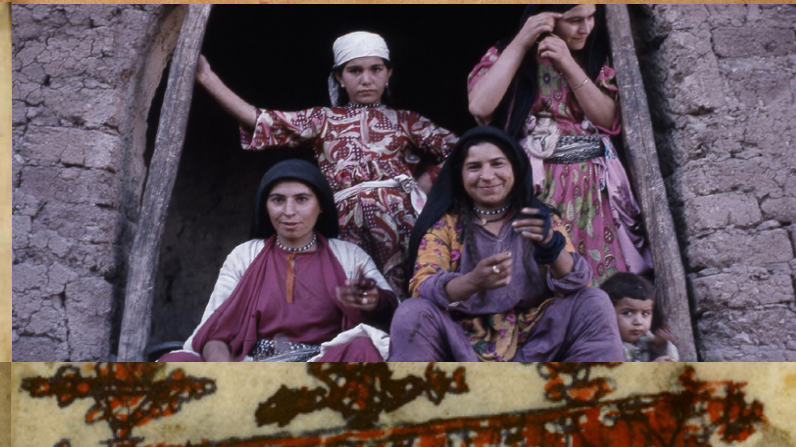
Pulshe

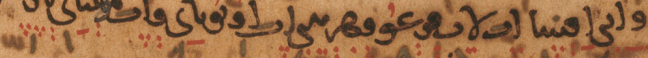
opr $\rightarrow$ 7 is pitolin a d I.

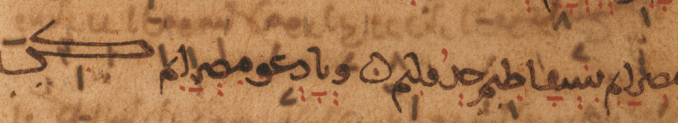
, $4,1,1,2,2$, 10 at $m=x^{2} n=a$ (i)

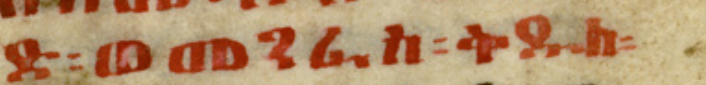

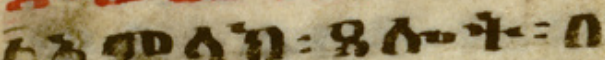




\section{About the series}

This series is published by Open Book Publishers in collaboration with the Faculty of Asian and Middle Eastern Studies of the University of Cambridge. The aim of the series is to publish in open-access form monographs in the field of Semitic languages and the cultures associated with speakers of Semitic languages. It is hoped that this will help disseminate research in this field to academic researchers around the world and also open up this research to the communities whose languages and cultures the volumes concern. This series includes philological and linguistic studies of Semitic languages, editions of Semitic texts, and studies of Semitic cultures. Titles in the series will cover all periods, traditions and methodological approaches to the field. The editorial board comprises Geoffrey Khan, Aaron Hornkohl, and Esther-Miriam Wagner.

This is the first Open Access book series in the field; it combines the high peer-review and editorial standards with the fair Open Access model offered by OBP. Open Access (that is, making texts free to read and reuse) helps spread research results and other educational materials to everyone everywhere, not just to those who can afford it or have access to well-endowed university libraries.

Copyrights stay where they belong, with the authors. Authors are encouraged to secure funding to offset the publication costs and thereby sustain the publishing model, but if no institutional funding is available, authors are not charged for publication. Any grant secured covers the actual costs of publishing and is not taken as profit. In short: we support publishing that respects the authors and serves the public interest.

\section{Other titles in the series}

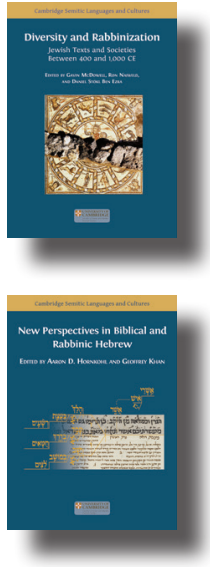

Diversity and Rabbinization: Jewish Texts and Societies between 400 and $1000 C E$

Gavin McDowell, Ron Naiweld,

Daniel Stökl Ben Ezra (eds)

doi.org/10.11647/OBP.0219

New Perspectives in Biblical and Rabbinic Hebrew

Aaron D. Hornkohl and Geoffrey Khan (eds)

doi.org/10.11647/OBP.0250

UNIVERSITY OF

CAMBRIDGE

Faculty of Asian and Middle

Eastern Studies

You can find more information about this serie at:

http://www.openbookpublishers.com/section/107/1 


\section{A Handbook and Reader of Ottoman Arabic}

\section{Edited by Esther-Miriam Wagner}

Written forms of Arabic composed during the era of the Ottoman Empire present an immensely fruitful linguistic topic. Extant texts display a proximity to the vernacular that cannot be encountered in any other surviving historical Arabic material, and thus provide unprecedented access to Arabic language history.

This rich material remains very little explored. Traditionally, scholarship on Arabic has focussed overwhelmingly on the literature of the various Golden Ages between the 8th and 13th centuries, whereas texts from the 15th century onwards have often been viewed as corrupted and not worthy of study. The lack of interest in Ottoman Arabic culture and literacy left these sources almost completely neglected in university courses.

This volume is the first linguistic work to focus exclusively on varieties of Christian, Jewish and Muslim Arabic in the Ottoman Empire of the 15th to the 20th centuries, and present Ottoman Arabic material in a didactic and easily accessible way. Split into a Handbook and a Reader section, the book provides a historical introduction to Ottoman literacy, translation studies, vernacularisation processes, language policy and linguistic pluralism. The second part contains excerpts from more than forty sources, edited and translated by a diverse network of scholars.

The material presented includes a large number of yet unedited texts, such as Christian Arabic letters from the Prize Paper collections, mercantile correspondence and notebooks found in the Library of Gotha, and Garshuni texts from archives of Syriac patriarchs.

This is the author-approved edition of this Open Access title. As with all Open Book publications, this entire book is available to read for free on the publisher's website. Printed and digital editions, together with supplementary digital material, can also be found at http://www.openbookpublishers.com

Cover images: Upper left, T-S 10J16.26 (Hebrew script); upper right, CUL Or.1081.2.75.2 (Syriac script), both reproduced with kind permission of the Syndics of Cambridge University Library. Image below, from box HCA 32/212 from the The National Archives. Cover design: Anna Gatti

OpenBook Publishers
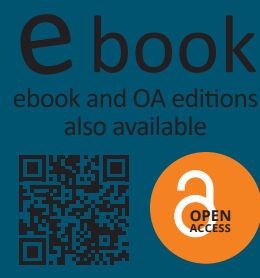